Livros didáticos de Matemática do Brasil e Canadá: um enfoque em construção geométrica nos anos finais do ensino fundamental

Leonardo Cascio de Souza

DISSERTAÇÃO APRESENTADA

AO

INSTITUTO DE MATEMÁTICA E ESTATÍSTICA

DA

UNIVERSIDADE DE SÃO PAULO

PARA

OBTENÇÃO DO TÍTULO

DE

MESTRE EM CIÊNCIAS

Orientadora: Prof. ${ }^{a}$ Dr. Circe Mary Silva da Silva Dynnikov 


\title{
Livros didáticos de Matemática do Brasil e Canadá: um enfoque em construção geométrica nos anos finais do ensino fundamental
}

\author{
Leonardo Cascio de Souza
}

\section{Versão final (corrigida)}

\begin{abstract}
Esta versão da dissertação contém as correções e alterações sugeridas pela Comissão Julgadora durante a defesa da versão original do trabalho, realizada em 15/05/2019. Uma cópia da versão original está disponível no Instituto de Matemática e Estatística da Universidade de São Paulo.
\end{abstract}

Orientadora: Prof. ${ }^{a}$ Dr ${ }^{a}$ Circe Mary Silva da Silva Dynnikov

Comissão Julgadora:

- Prof. ${ }^{a}$ Dr ${ }^{a}$ Circe Mary Dynnikov (orientadora) - UFES (IME)

- Prof. ${ }^{\text {a }}$ Dr ${ }^{a}$ Vanessa Dias Moretti - UNIFESP

- Prof. Dr Armando Traldi Junior - IFSP 
À minha família e amigos, que me apoiaram, acreditaram e deram força em momentos de fraqueza e tristeza. 


\section{AGRADECIMENTOS}

Inicialmente agradeço aos meus pais, Claudia e Paulo, a minha irmã Bianca e a outros familiares que estiveram presentes não só nesse momento, mas por toda a minha vida.

Aos meus grandes amigos Lucas, Otávio, Marcello, Tamyres, Roberta, Léo, Thalita, Leonardo, Luciana, Tuanny, Letícia e tantos outros que participaram da minha vida, seja auxiliando diretamente na dissertação, ou apenas estando ao meu lado nos momentos mais difíceis desse projeto.

Agradeço também aos colegas que fiz durante a graduação e o mestrado, em especial, Rafael, André, Ana Carolina, Luana, Camila, Aline, Jéssica, Igor, Thales, Vinícius e Thiago. Aos professores Henrique Marins, Elisabete Guerato, Luciano Magrini, Marco Aurélio Granero, Fabiane Marcondes, Gabriela Cotrim, Armando Traldi, Vânia Flores, Ana Paula Jahn, Antônio Carlos Brolezzi, Marcos Magalhães, Ricardo Bianconi, Vanessa Moretti e Saddo Ag Almouloud por serem exemplos nessa carreira tão fundamental para todos.

Agradecimento especial para professora Circe Dynnikov, que além de orientar tal projeto, auxiliou em momentos difíceis da minha vida, emitindo paciência para que eu finalizasse a dissertação, ao meu grande amigo Victor Ferri, por adquirir os livros canadenses por mim, a minha amiga Fernanda Lima, por auxiliar na revisão do trabalho e a Michelle Covacho, que mesmo não estando presente ao término do projeto, foi fundamental em todas as etapas, desde o início do TCC da graduação até a qualificação do projeto de mestrado. 
"A educação é um processo social, é desenvolvimento.

Não é a preparação para a vida, é a própria vida." John Dewey 


\section{RESUMO}

SOUZA, L. C. Livros didáticos de Matemática do Brasil e Canadá: um enfoque em construção geométrica nos anos finais do ensino fundamental. 2019. 162 f. Dissertação (Mestrado Profissional no Ensino de Matemática) - Instituto de Matemática e Estatística, Universidade de São Paulo, 2019.

A dissertação discute a abordagem de conceitos de construção geométrica nos livros didáticos dos anos finais do ensino fundamental do Brasil e Canadá. Para isso, pesquisamos o papel da construção geométrica na educação, da utilização dos livros didáticos e a relevância da análise comparativa na área. As fontes utilizadas foram os documentos oficiais: orientações curriculares brasileiras (PCN) e canadenses the Ontario Curriculum); quatro coleções de livros: Projeto Teláris, Matemática na Medida Certa, Nelson Mathematics e Math Makes Sense; guia do livro didático (Brasil e Canadá). Usando a análise documental como modalidade de pesquisa, buscamos responder à pergunta: como os saberes relacionados ao desenho geométrico são representados em cada coleção e quais as principais diferenças e semelhanças entre os livros didáticos brasileiros e canadenses? Concluímos que algumas obras se destacam, como Projeto Teláris e Math Makes Sense, pois se aproximam das orientações de seus respectivos currículos. Encontramos, também, poucas construções comuns a todas as obras, apenas circunferência e triângulo, e que o conteúdo de construção geométrica por muitas vezes encontra-se incompleto nas coleções.

Palavras-chave: Análise comparativa, construção geométrica, livros didáticos. 


\begin{abstract}
SOUZA, L. C. Mathematics textbooks in Brazil and Canada: an approach in geometric construction in the final years of elementary school. 2019. 162 p. Dissertation (Master's Degree in Mathematics - Instituto de Matemática e Estatística, Universidade de São Paulo, 2019.

The dissertation discusses the approach of geometric construction concepts in both Brazilian and Canadian mathematics textbooks in the final years of elementary school. A study was conduct on the role of geometric construction and the use of textbooks, as well as the relevance of comparative analysis within the discipline. The research primary sources were based on official documents, including the Brazilian curricular orientation (PCN) and the Canadian one (the Ontario Curriculum); four textbook collections: Projeto Teláris, Matemática na Medida Certa, Nelson Mathematics and Math Makes Sense; and the guide of textbooks (Brazil and Canada).The method used to carry out the research is documental analysis, and the goal of the study is to identify and explain how the content of geometric shapes are represented on each book collection and which are the main differences and similarities between Brazilian and Canadian textbooks. The findings showed that the book Projeto Teláris and Math Makes Sense stand out for following their respective curricular orientations. It was also concluded that only a small amount of shapes were common to all textbooks, specifically circle and triangle, and that the geometric construction content is, in great majority, incomplete in all colections.
\end{abstract}

Key words: Comparative analysis, geometric construction, textbooks. 


\section{LISTA DE FIGURAS}

Figura 1 - Capa Projeto Teláris - Matemática $6 \ldots \ldots \ldots \ldots \ldots \ldots \ldots \ldots \ldots \ldots \ldots \ldots \ldots \ldots \ldots \ldots \ldots \ldots \ldots \ldots \ldots \ldots \ldots . . .62$

Figura 2 - Projeto Teláris - Matemática 6 - p. 78 ...............................................................63

Figura 3 - Projeto Teláris - Matemática 6 - p. 82 ............................................................65

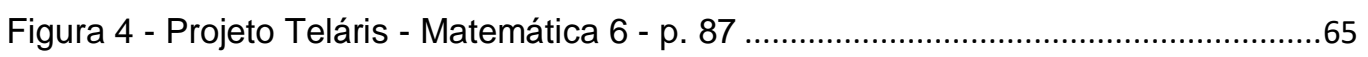

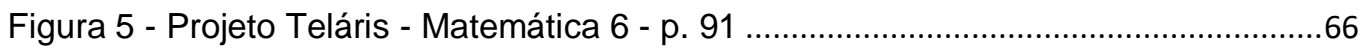

Figura 6 - Projeto Teláris - Matemática 6 - p. 92 ..............................................................67

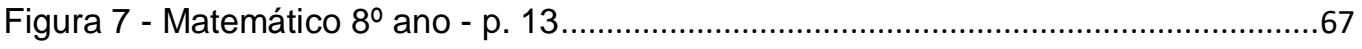

Figura 8 - Projeto Teláris - Matemática 6 - p. 92 …………………………...................6

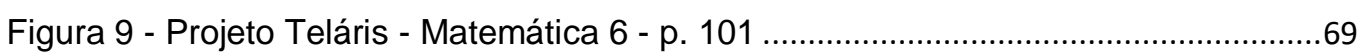

Figura 10 - Projeto Teláris - Matemática 6 - p. 100 …………………………………......69

Figura 11 - Projeto Teláris - Matemática 6 - pg. 102 ……..................................................70

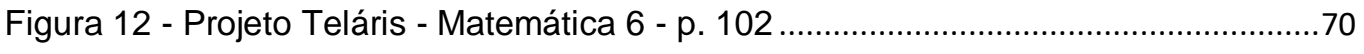

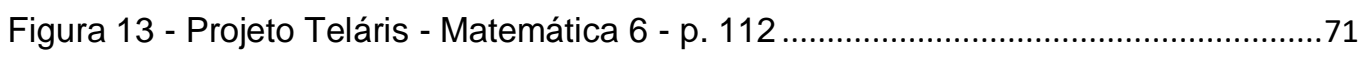

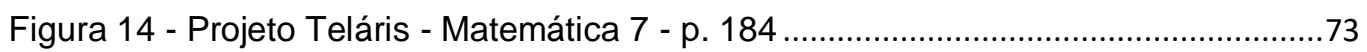

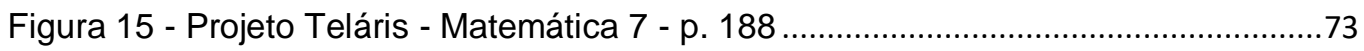

Figura 16 - Projeto Teláris - Matemática 7 - p. 189 ………………………………............74

Figura 17 - Projeto Teláris - Matemática 7 - p. 198 .......................................................... 74

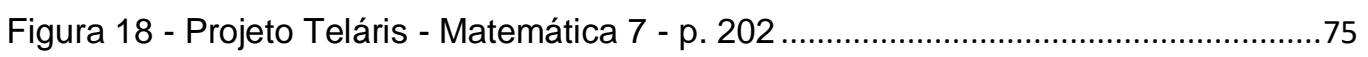

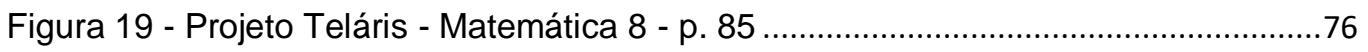

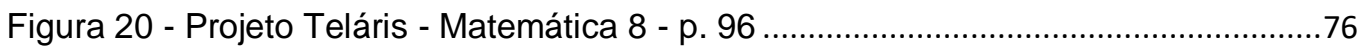

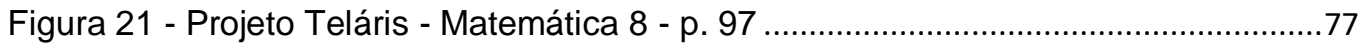

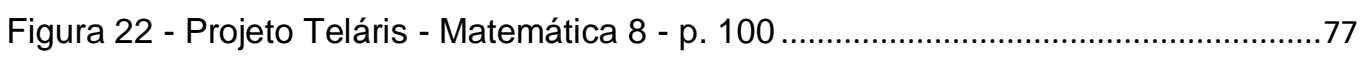

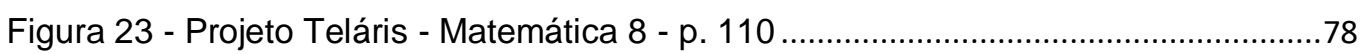

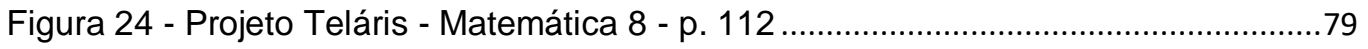

Figura 25 - Projeto Teláris - Matemática 8 - p. 117 ........................................................

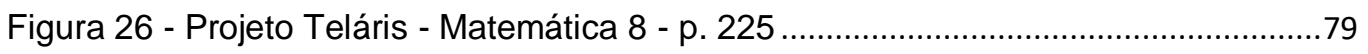

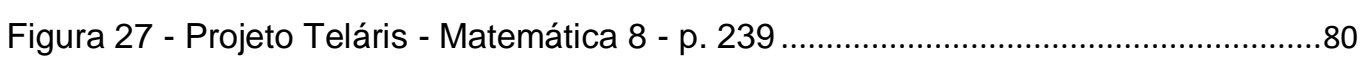

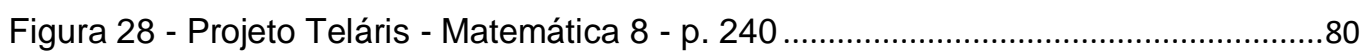

Figura 29 - Projeto Teláris - Matemática 8 - p. 240.2 ……………………...................... 81

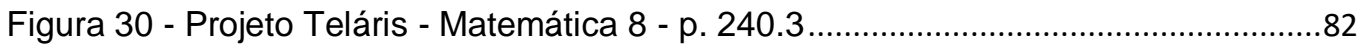

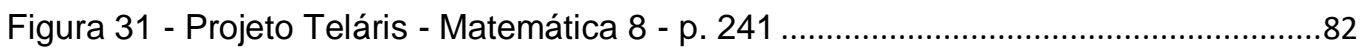

Figura 32 - Projeto Teláris - Matemática 9 - p. 149 ……...................................................

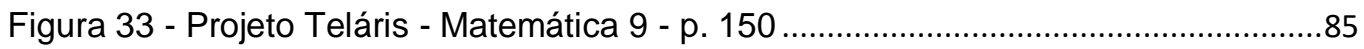

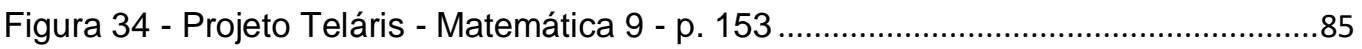

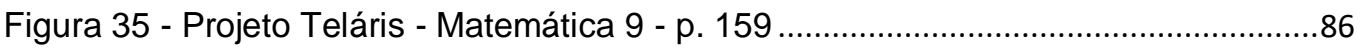

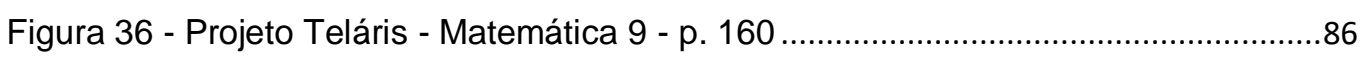


Figura 37 - Capa Matemática na medida certa 6 ........................................................... 89

Figura 38 - Matemática na medida certa 6 - p. 8 e 9 .......................................................90

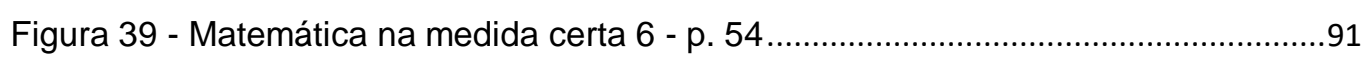

Figura 40 - Matemática na medida certa 6 - p. 62 ........................................................92

Figura 41 - Matemática na medida certa 6 - p. 63 .............................................................92

Figura 42 - Matemática na medida certa 6 - p. 66 .........................................................93

Figura 43 - Matemática na medida certa 7 - p. 163 ........................................................94

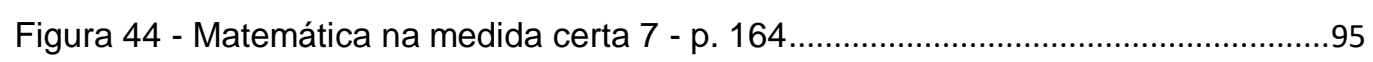

Figura 45 - Matemática na medida certa 7 - p. 176.1 ….................................................95

Figura 46 - Matemática na medida certa 7 - p. 176.2 ……..............................................96

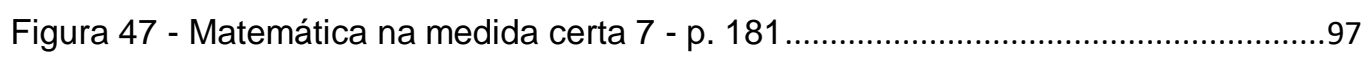

Figura 48 - Matemática na medida certa 7 - p. 182 ........................................................97

Figura 49 - Matemática na medida certa 7 - p. 183.1........................................................98

Figura 50 - Matemática na medida certa 7 - p. 183.2.....................................................99

Figura 51 - Matemática na medida certa 8 - p. 130.1 ......................................................100

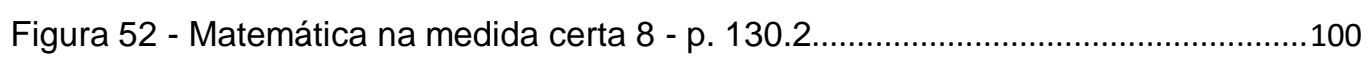

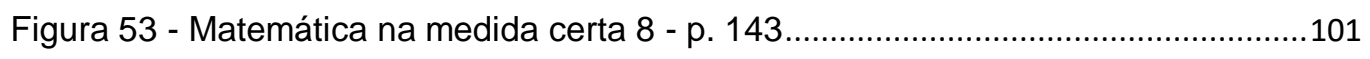

Figura 54 - Matemática na medida certa 8 - p. 151 ........................................................102

Figura 55 - Matemática na medida certa 8 - p. 152 ...................................................... 102

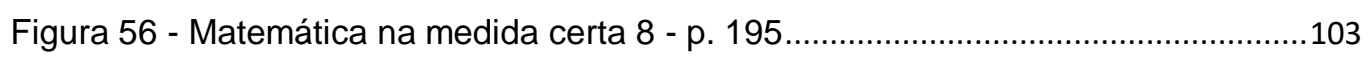

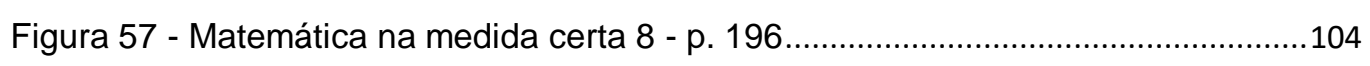

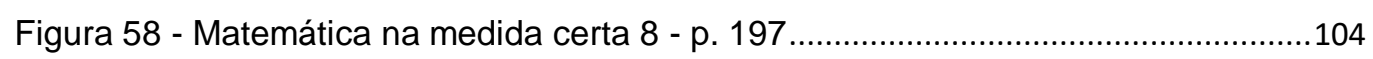

Figura 59 - Matemática na medida certa 8 - p. 198.1 ……............................................105

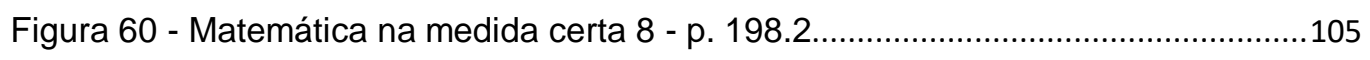

Figura 61 - Matemática na medida certa 8 - p. 199....................................................... 106

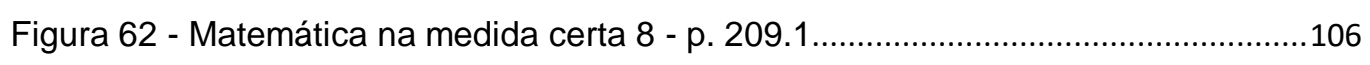

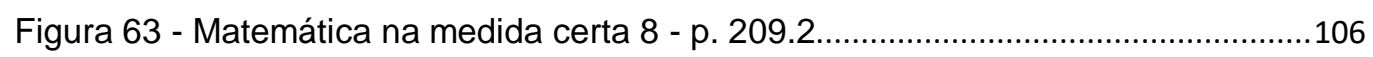

Figura 64 - Matemática na medida certa 9 - p. 16 ......................................................... 108

Figura 65 - Matemática na medida certa 9 - p. 139.....................................................109

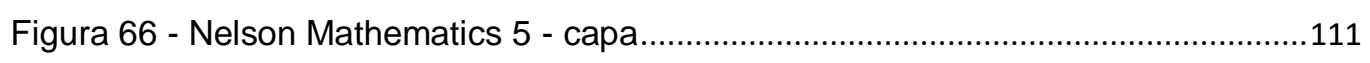

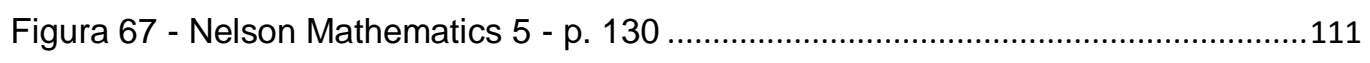

Figura 68 - Nelson Mathematics 5 - p. 192 ..................................................................113

Figura 69 - Nelson Mathematics 5 - p. 193 …………................................................113

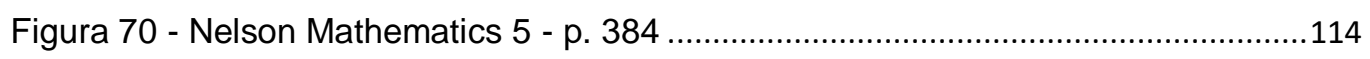

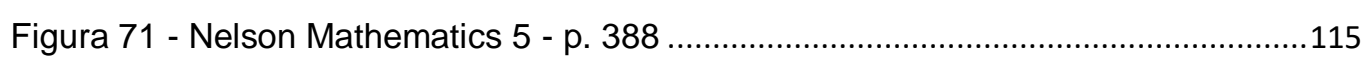

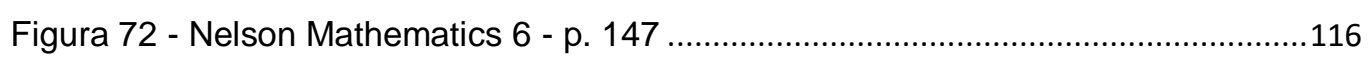

Figura 73 - Nelson Mathematics 6 - p. 210 ..................................................................117

Figura 74 - Nelson Mathematics 6 - p. 214 ................................................................118 


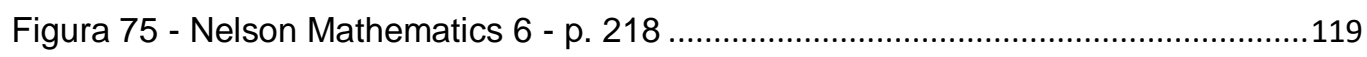

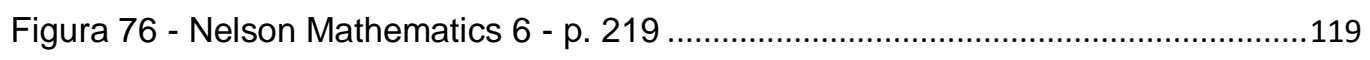

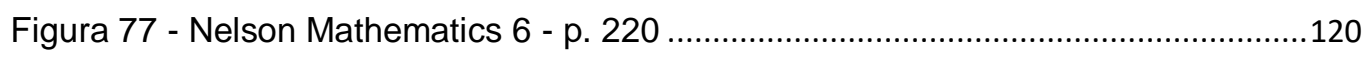

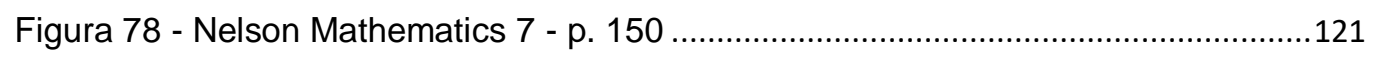

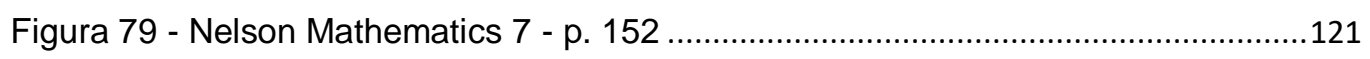

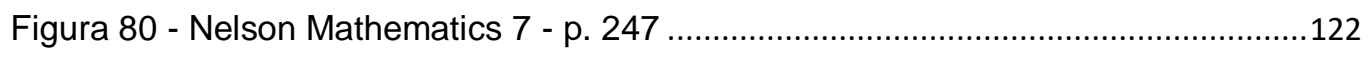

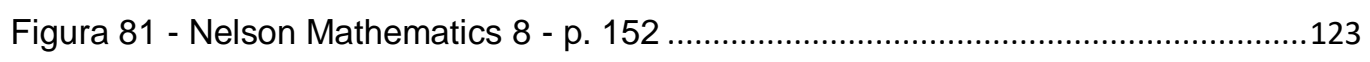

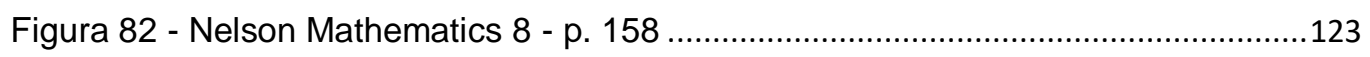

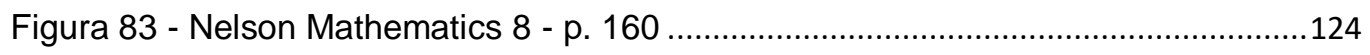

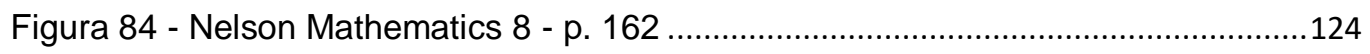

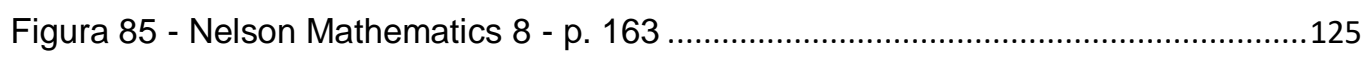

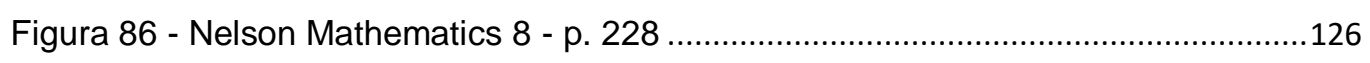

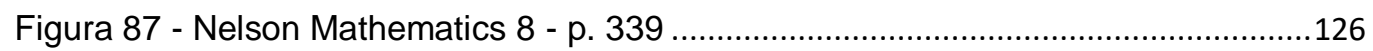

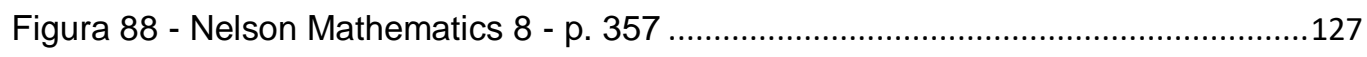

Figura 89 - Math makes sense 5 - capa …………........................................................129

Figura 90 - Math makes sense - plataforma digital.......................................................129

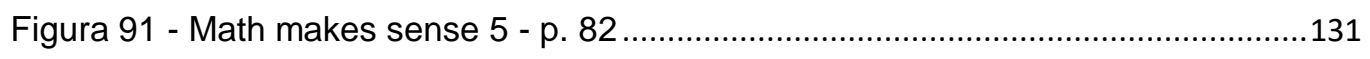

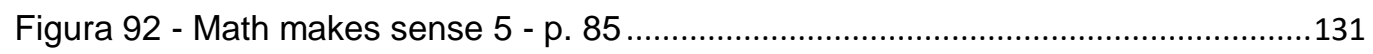

Figura 93 - Math makes sense 5 - p. 94 .....................................................................132

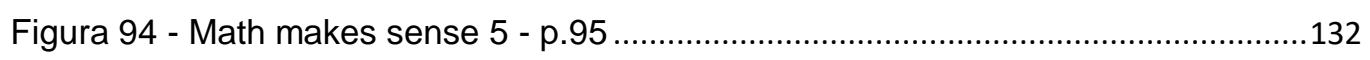

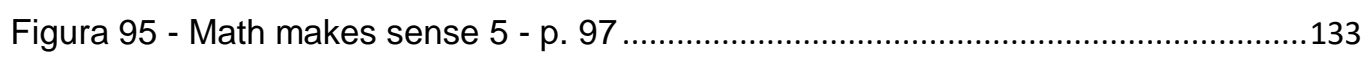

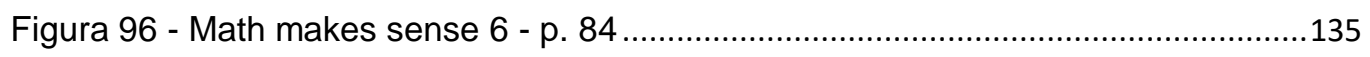

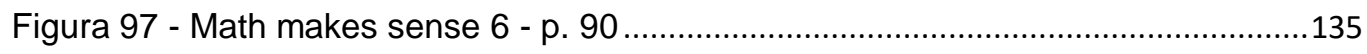

Figura 98 - Math makes sense 6 - p. 93 ....................................................................136

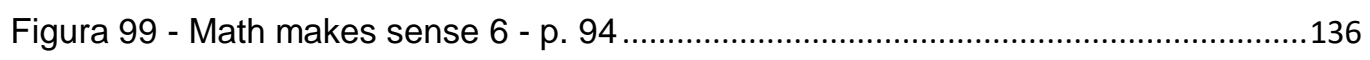

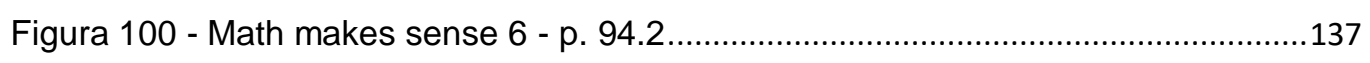

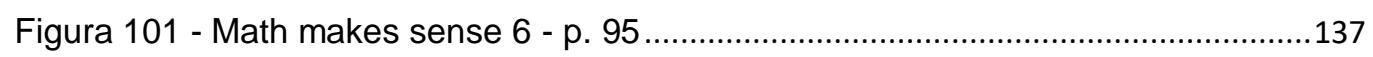

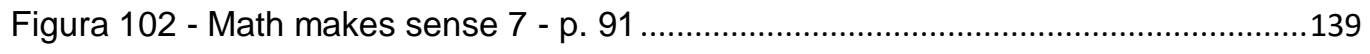

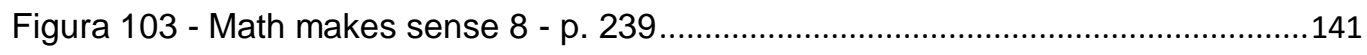

Figura 104 - Math makes sense 8 - p. 241 ..................................................................141

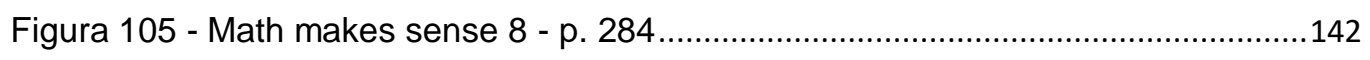

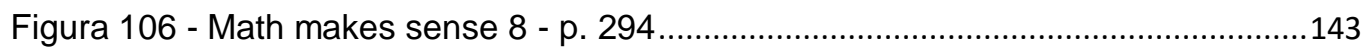

Figura 107 - Math makes sense 8 - p. 295.1 ..................................................................144

Figura 108 - Math makes sense 8 - p. 295.2..................................................................144

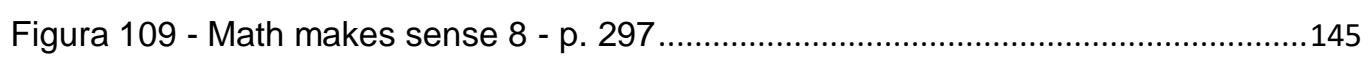

Figura 110 - Math makes sense 8 - p. 298 ...............................................................146

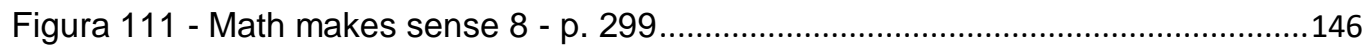

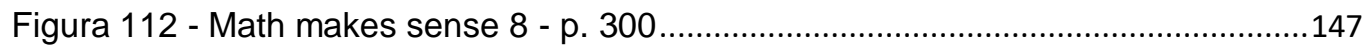


Figura 113 - Math makes sense 8 - p. 302 ………........................................................147

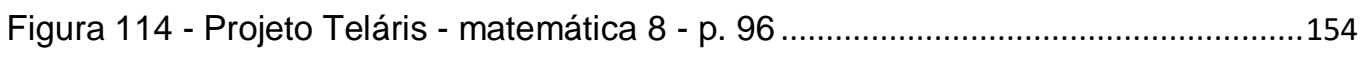

Figura 115 - Matemática na medida certa 8 - p. 196 ....................................................154

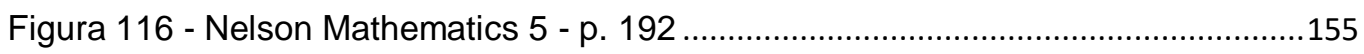

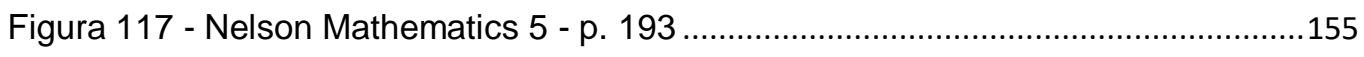

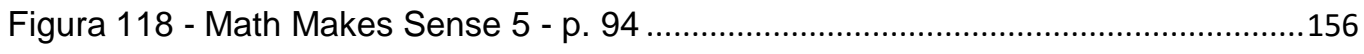

Figura 119 - Math Makes Sense 5 - p. 95 ……...........................................................156 


\section{LISTA DE QUADROS}

Quadro 1 - Comparativo entre currículo brasileiro e canadense....................................58

Quadro 2 - Comparativo entre documentos oficiais brasileiros e canadenses.................59

Quadro 3 - Conteúdos de construção geométrica Projeto Teláris ....................................87

Quadro 4 - Conteúdos de construção geométrica Matemática na medida certa ...........110

Quadro 5 - Conteúdos de construção geométrica Nelson Mathematics ..........................128

Quadro 6 - Conteúdos de construção geométrica Math Makes Sense ...........................148

Quadro 7 - Construções geométricas nas quatro coleções.............................................151

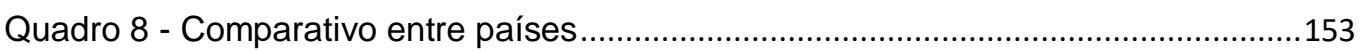




\section{SUMÁRIO}

1. INTRODUÇÃO

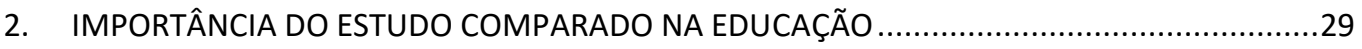

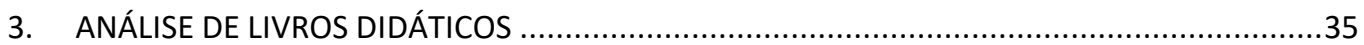

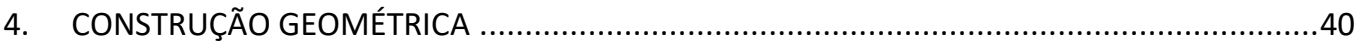

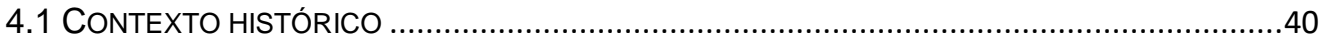

4.2 IMPORTÂNCIA DO DESENHO GEOMÉTRICO NA APRENDIZAGEM .......................................4

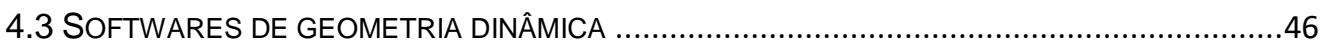

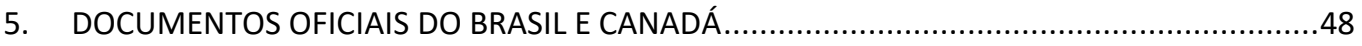

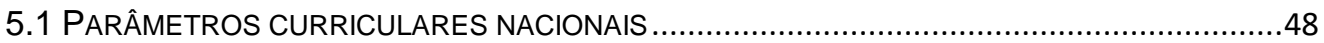

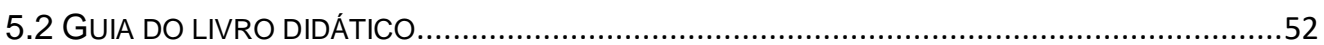

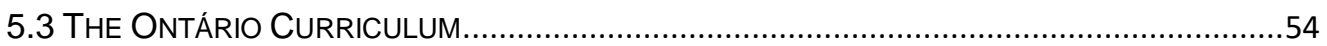

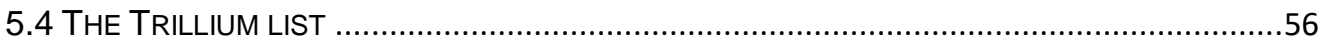

6. A CONSTRUÇÃO GEOMÉTRICA NOS LIVROS DIDÁTICOS DE MATEMÁTICA SELECIONADOS 60

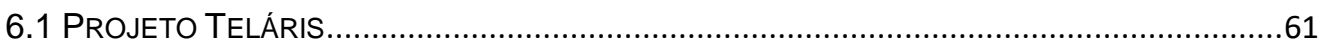

6.1.1 Projeto Teláris 6

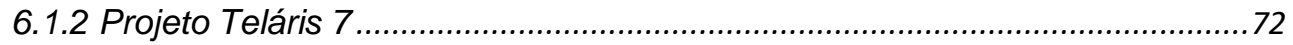

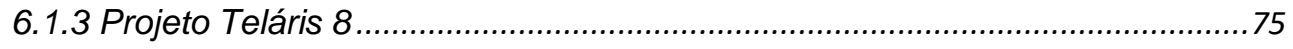

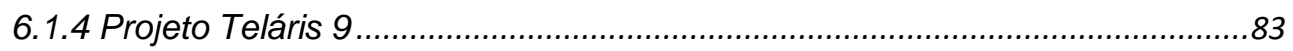

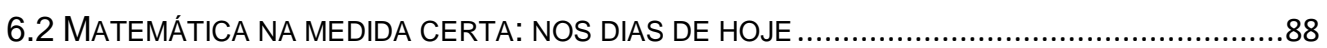

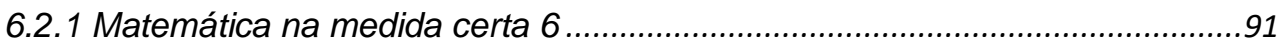

6.2.2 Matemática na medida certa 7 ......................................................................94

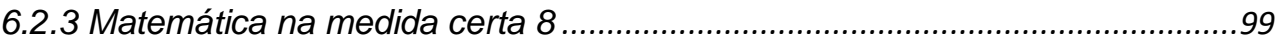

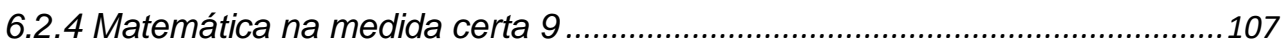

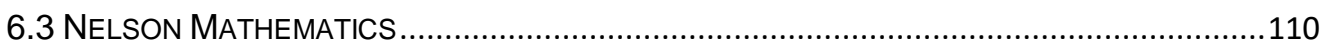

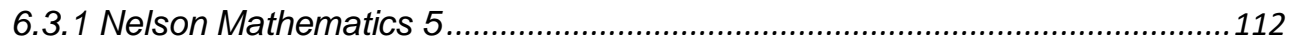

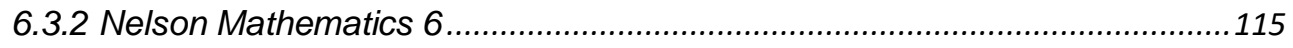

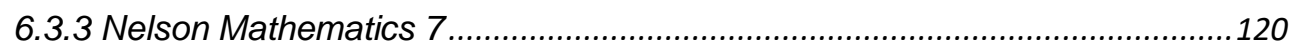

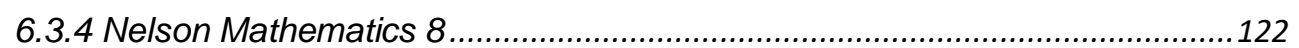

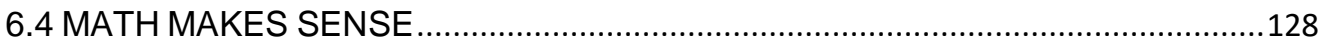

6.4.1 Math Makes Sense 5 ………………………...........................................130

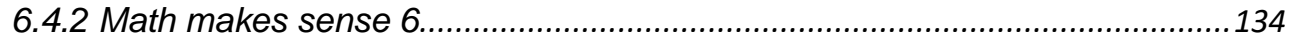

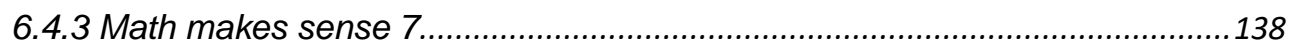


6.4.4 Math makes sense 8.

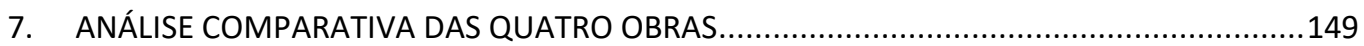

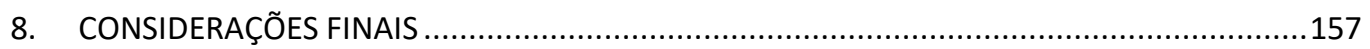

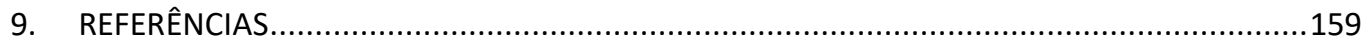




\section{INTRODUÇÃO}

No atual cenário da educação Brasileira, particularmente no âmbito do ensino da matemática, algumas indagações precisam ser feitas, para, assim, proporcionar orientação em possíveis reformas e aperfeiçoamentos. Um método possível para responder tais indagações seria analisar o sistema de ensino da matemática de outros países comparando-os, exibindo percepções diversas.

O estudo comparado é intrínseco à produção intelectual pois, com particularidades e diferenças, podemos caracterizar grupos diferentes, como diz Ciavatta:

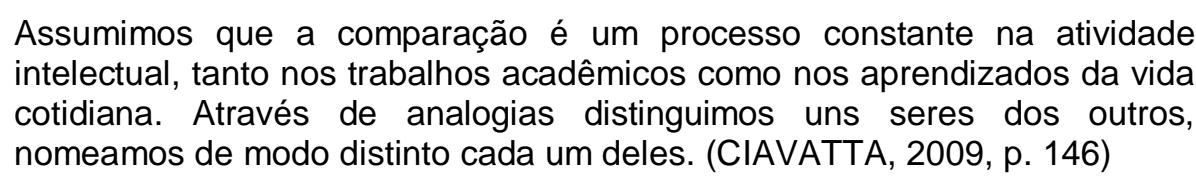

$\mathrm{Na}$ última década, diversas pesquisas mundiais referentes à educação mostraram o baixo nível educacional do Brasil, como no ranking "A curva de Aprendizado", elaborado pelo instituto Pearson e The Economist Intelligent Unit no ano de 2014, onde o Brasil ficou em 38 lugar em um total de 40 países. Além disso, as pesquisas nacionais também mostraram um nível abaixo do desejado em diversas áreas do conhecimento, incluindo a matemática.

Segundo o resultado do PISA (Programme for International Student Assessment) de 2015, o Brasil está na 66⿳a posição em Educação Matemática (em um total de 70 países), com 377 pontos. Com relação às avaliações nacionais, tais como SAEB (Sistema de Avaliação da Educação Básica), as pesquisas também mostram o nível alarmante, como diz Pereira dos Santos e Tolentino-Neto (2015, p.21) "Nossa análise de dados reforça o encontrado na literatura da área, visto que a maioria das pesquisas enfatiza o baixo desempenho em Matemática". Oliveira Souza também ressalta o baixo número de alunos no nível adequado segundo o SAEB:

1 The Learning Curve is a global project to help influence education policy and practices, at local, regional and national levels. Disponível em: http://thelearningcurve.pearson.com/. Acessado em: 01/03/2017 
Em relação à matemática, por exemplo, os resultados do SAEB, em seus diversos Ciclos de avaliação, têm mostrado que esta disciplina ainda é uma das que apresentam os menores índices de rendimento por parte dos alunos. De modo geral, as pesquisas têm alertado para o fato de que a maioria dos estudantes avança pouco em seus processos escolares, na medida em que mais da metade dos estudantes avaliados não consegue atingir o nível adequado da escala de proficiência do SAEB. (OLIVEIRA SOUZA, 2014, p.5)

\section{Para a OECD (Organization for Economic Cooperation and} Development), responsável pelo PISA, o Brasil, no ano de 2015, declinou 11 pontos em relação ao PISA de 2012. Mesmo a queda sendo consideravelmente baixa, ainda existe preocupação, pois entre os anos de 2003 e 2012 houve um aumento de 21 pontos.

Utilizando o mesmo ranking, temos o Canadá na 9o posição, com 516 pontos, sendo, assim, o país de língua inglesa mais bem colocado (lembrando que o francês também é língua oficial do Canadá). Ainda, a OECD cita o Canadá como um dos únicos a alcançar o nível máximo de proficiência nas três áreas do PISA (Ciência, Leitura e Matemática).

Somente no Canadá, Estônia, Finlândia, Hong Kong (China), Japão, Macau (China) e Cingapura pelo menos quatro de cada cinco estudantes de 15 anos dominam o nível básico de proficiência em ciência, leitura e matemática. ${ }^{2}$ (OECD, 2016, p.4, tradução livre do autor)

Para o Canadá, permanecer entre os 10 melhores países em educação Matemática no ranking do PISA não é surpresa, já que está entre os sete melhores sistemas educacionais do mundo, como mostra Lima:

D

A própria OECD, em sua publicação de resultados do PISA, salienta o sistema educacional canadense:

Os sistemas educativos que conseguiram obter resultados de aprendizagem fortes e equitativos mostram a outros o que é possível alcançar. [...] $O$ Canadá, a Dinamarca, a Estónia, Hong Kong (China) e Macau (China) destacam-se por terem um elevado desempenho e uma boa equidade nas oportunidades de educação ${ }^{3}$. (OECD, 2016, p. 208, tradução livre do autor)

2 Tradução livre do texto: "Only in Canada, Estonia, Finland, Hong Kong (China), Japan, Macao (China) and Singapore do at least four out of five 15-year-old students master the baseline level of proficiency in science, reading and mathematics".

3 Tradução livre do texto: "The education systems that have been able to secure strong and equitable learning outcomes show others what is possible to achieve. [...]Canada, Denmark, Estonia, Hong Kong (China) and Macao (China) stand out by achieving both high performance and high equity in education opportunities." 
Ao comparar os resultados do PISA 2015 na área de matemática do Brasil (66ํㅜ colocado) com o Canadá (9ำ colocado), é visível a discrepância dos sistemas educacionais (em relação a colocação no ranking), mas deve-se compreender as diferenças culturais entre os dois países, cada qual com sua realidade própria. Com isso, a primeira indagação é o motivo de tal diferença, o que não pode ser respondido com facilidade, já que diversos fatores corroboram para o sucesso ou não de um sistema educacional. Para Franco et al (2007), alguns dos fatores associados à eficácia escolar são: recursos escolares, organização e gestão da escola, clima acadêmico, formação, salário docente e ênfase pedagógica.

Os itens listados acima são referentes a unidades de ensino, mas podem ser extrapolados em nível nacional, pois os fatores são relevantes para qualquer sistema educacional. Com isso, é possível subdividir os fatores citados em diversos itens, como: formação de professores, orçamento destinado para a educação, cultura escolar (qual a importância da educação segundo a sua população), currículos utilizados, materiais utilizados, qualidade do espaço escolar, entre outros.

Entre os itens acima temos o livro didático e, segundo Dante (1996), a escolha adequada do mesmo pode transformá-lo em um dos principais recursos para um bom ensino de matemática. Para salientar tal afirmação, Dante enumera diversas razões para tal. Dentre estas razões, citamos a quantidade de problemas e exercícios de fixação, o fácil manuseio entre os conteúdos, já que a matemática é uma disciplina sequencial de acesso a definições, propriedades e tabelas.

Durante anos o livro foi utilizado pelos professores, principalmente como um auxiliar no ensino aprendizagem de seus alunos, como observamos no guia de livros didáticos brasileiros do ano de 2017:

Cabe à escola, em particular ao professor, a condução do processo de ensino e o acompanhamento da aprendizagem dos estudantes. Nessa tarefa complexa, a grande maioria dos educadores atribui ao livro um papel de destaque entre os recursos didáticos que podem ser utilizados. O livro didático traz para o processo de ensino e aprendizagem mais um elemento, o seu autor, que passa a dialogar com o professor e com o estudante. Nesse diálogo, o livro é portador de escolhas sobre: o saber a ser estudado (a Matemática); os métodos adotados para que os estudantes consigam aprendê-lo mais eficazmente; a organização curricular ao longo dos anos de escolaridade. (BRASIL, 2016, p.13) 
Diversos trabalhos na última década trazem como temática a análise de livros didáticos, como Rosa et al (2012), Silva (2015), Guimarães (2015) e Santana Filho (2017). Uma análise competente pode auxiliar o professor em diversos pontos, mas também é capaz de encontrar falhas na sua composição, como diz Rosa:

Ao analisar livros didáticos é possível perceber a existência de falhas na
sua composição, às vezes na forma de apresentação do conteúdo, nas
atividades propostas, no desenvolvimento dos conceitos no decorrer das
páginas, ou ainda de inadequação à realidade local, às práticas sociais do
grupo escolar em questão. (ROSA et al, 2012, p. 3)

Vista a importância da análise de livros didáticos, o objetivo deste trabalho é analisar e comparar livros didáticos brasileiros e canadenses, para, assim, iniciar um amplo projeto comparativo dos sistemas educacionais. A análise não possui o intuito de encontrar o fator decisivo para a diferença do nível educacional entre Brasil e Canadá, mas sim identificar conteúdos e metodologias de ensino utilizadas.

Segundo o guia dos livros didáticos brasileiros de 2017, os livros didáticos são divididos em cinco campos da matemática escolar: números e operações; álgebra; geometria; grandezas e medidas; estatística e probabilidade. Para o trabalho atual analisaremos conteúdos vinculados ao campo da geometria.

Para a análise dos livros didáticos o conteúdo escolhido foi retirado do campo da geometria. Com isso, o enfoque não será em uma série ou ano específico, mas sim no livro em que o conteúdo é apresentado.

Pesquisas como as de Mocrosky, Mondini e Estephan (2012), Leivas (2012) e Júnior (2013) salientam a importância do campo da geometria. Não só a comunidade de educadores, mas toda a sociedade valoriza o conhecimento geométrico, pois sua presença no cotidiano é constante, como diz Mocrosky, Mondini e Estephan:

Vários são os motivos que levam a comunidade de educadores e a sociedade em geral a valorizar os conhecimentos advindos da geometria: sua presença está na forma dos objetos, nas edificações da construção civil, nas necessidades de desenvolvermos senso de localização, direção, sentido e na possibilidade que ela nos oferece para a resolução de problemas nas mais diversas áreas. De um modo geral ela é formativa, pois capacita o ser humano para a tarefa de interpretar e compreender o mundo. Além disso, favorece o processo de abstração e generalização das relações percebidas ao estarmos no mundo, contribuindo para a articulação entre o intuitivo e o formal, abrangendo os aspectos históricos trazidos pela 
atividade exclusivamente geométrica à abertura aos meios algébricos. (MOCROSKY, MONDINI e ESTEPHAN, 2012, p.1)

Nos últimos anos, no campo da geometria, a construção geométrica tem sido muito pesquisada e discutida. Entre os autores, temos Souza (2013), Silva (2015), Souza (2015) e Araújo (2016). Também conhecido como "desenho geométrico", este tem como objetivo a elaboração de objetos geométricos (retas, circunferências, polígonos, entre outros) utilizando apenas régua e compasso. Além do uso na geometria, também é possível utilizar este conhecimento para solucionar problemas algébricos e resolver operações básicas.

Segundo Silva (2013), com a construção geométrica o aluno compreende o conteúdo de forma mais consistente, pois com as mãos em ação a memorização e a absorção do conhecimento aumentam. Souza ainda diz:

[...] o Desenho Geométrico permite concretizar os conhecimentos teóricos da Geometria, confirmando as propriedades das figuras geométricas, o que possibilita ao aluno uma maior habilidade na resolução de problemas correlatos. (SOUZA, 2015, p.48)

Assim, o objetivo primário da dissertação é analisar o desenho geométrico dos anos finais do ensino fundamental nos livros didáticos brasileiros e canadenses, destacando metodologias utilizadas, contextualizações, exercícios e conteúdos programáticos. Com isso, a principal pergunta a ser respondida é: como os saberes relacionados ao desenho geométrico são representados em cada coleção e quais as principais diferenças e semelhanças entre os livros didáticos brasileiros e canadenses?

O segundo capítulo traz um breve contexto sobre a importância de estudos comparativos na educação com alguns trabalhos importantes, corroborando na escolha dessa pesquisa. Na sequência é analisada a importância do livro didático com pesquisas recentes sobre esse tema.

O quarto capítulo ressalta a importância do desenho geométrico na educação, incluindo também um breve contexto histórico e salientando a importância dos softwares de geometria dinâmica na atualidade. A análise dos documentos oficiais é realizada no quinto capítulo, onde quatro documentos são verificados: PCN, Guia do livro didático, The Ontário Curriculum e Trillium List. 
No sexto capítulo temos as análises dos livros didáticos escolhidos com alguns comentários sobre a coleção como um todo, suas características físicas e a utilização (ou não) da construção geométrica ao longo da coleção.

Ao término, temos a conclusão da dissertação com ênfase nas questões mais importantes encontradas em toda a obra, além de aprofundar nas comparações entre as coleções escolhidas. Não se trata de responder qual coleção é a melhor, mas sim como o conteúdo em questão é abordado e se livros didáticos canadenses tendem a trabalhar mais o conteúdo, visto a melhor posição em pesquisas sobre educação. 


\title{
2. IMPORTÂNCIA DO ESTUDO COMPARADO NA EDUCAÇÃO
}

Como o presente trabalho tenciona realizar uma análise comparativa de livros didáticos, é importante salientar a influência do tema no meio acadêmico. Diversos autores nos últimos 30 anos dedicaram pesquisas em estudos comparados, sejam elas entre livros didáticos, currículos, metodologias ou sistemas educacionais.

Ciavatta (2009) ressalta a importância da comparação, não apenas na educação, mas na vida cotidiana do ser humano:

\begin{abstract}
A comparação é uma constante na produção intelectual, não apenas nos trabalhos acadêmicos, mas também nos aprendizados da vida cotidiana. Como haveríamos de nos considerar homens ou mulheres sem um exercício inicial de conhecer as características particulares das pessoas do sexo masculino e aquelas do sexo feminino e, por um processo de analogia entre uns e outros, encontrar as semelhanças e as diferenças e chamar a uns de homens e a outros de mulheres? E assim, indefinidamente, através de analogias, a humanidade e, ao longo dos tempos, cada ser humano que nasce e cresce vai distinguindo umas coisas das outras e se dando conta de como é e como se chama cada ser, objeto, fenômeno ou acontecimento que o rodeia. (CIAVATTA, 2009, p.130)
\end{abstract}

Ainda, Ciavatta (2009) aborda três questões preliminares sobre o estudo comparado: conhecimento e verdade; história e historicidade; sentido da comparação. Tais questões são fundamentais para o pensamento comparativo, criando, assim, uma análise aprofundada do tema em questão.

O conhecimento implica num vínculo entre o sujeito e o objeto da pesquisa, isto é, o sujeito necessita ter um conhecimento adequado para, assim, realizar comparações de forma objetiva, o que traz à tona o conceito de verdade, pois não existe uma única, segundo Fontes (2001). Além disso, verdades embasadas em interesses de classe, política e de poder não são, de fato, objetivas.

A história, isto é, a trajetória desses objetos comparados, também é relevante, pois entende-se como aquele objeto foi criado, para qual objetivo e quais dificuldades foram encontradas no percurso. Historicidade é situar o contexto no tempo e espaço, entender diferenças de cultura e época, pois tais variáveis são importantes para a análise do objeto. 
Comparar comportamentos educacionais de diversos países não é novidade. Como diz Valente (2012, p.169): "Encontros e congressos no início e na metade do século XX - que organizam as propostas de reformar a matemática escolar valorizam os inventários sobre as experiências nos diversos países". Tais experiências são consideradas na elaboração de modelos curriculares.

Entre esses encontros, temos o $5^{\circ}$ Congresso Internacional de Matemática, realizado em Cambridge no ano de 1912, onde discutia-se trabalhos comparando métodos e programas de instrução matemática de diversos países. A importância em comparar o ensino da matemática fica evidente, pois a matemática está presente de forma global:

Talvez seja possível dizer que já existe, na história da educação matemática, certa tradição de estudos comparativos. Afinal de contas, a matemática está presente em todos os currículos escolares de todos os países e isso enseja, facilmente, a troca de informações sobre esse ensino comum nas escolas de todo o mundo. (VALENTE, 2012, p. 166)

Schneider e Schmitt (1998) também salientam a importância global do uso de métodos comparativos:

A comparação, enquanto momento da atividade cognitiva, pode ser
considerada como inerente ao processo de construção do conhecimento
nas ciências sociais. É lançando mão de um tipo de raciocínio comparativo
que podemos descobrir regularidades, perceber deslocamentos e
transformações, construir modelos e tipologias, identificando continuidades
e descontinuidades, semelhanças e diferenças. (SCHNEIDER; SCHMITT,
1998, p. 49)

Entre os trabalhos sobre estudo comparado, temos o artigo intitulado "Sistemas educacionais comparados", de Fleury e Mattos (1991). Nele, as autoras comparam o sistema educacional Paulista com o de diversos países: Estados Unidos, França, Alemanha, Japão, Coréia do Sul e Cuba. Alguns dos pontos abordados pelas autoras são: estruturação do sistema educacional; taxa de escolarização; despesas com educação por aluno; indicadores de desempenho.

Ao término da pesquisa as autoras concluem que, mesmo que todos os países tenham o mesmo objetivo de universalizar e democratizar a educação, alguns fatores diferem o Brasil (especificamente o estado de São Paulo) com o restante dos países pesquisados, como o baixo investimento em educação, baixos 
salários para professores, tempo reduzido na escola e sacrifício da qualidade em prol da quantidade.

Carvalho (2015), em sua dissertação intitulada "Um estudo comparativo entre educação matemática entre Brasil e Japão", analisa em diversos pontos o sistema educacional dos países envolvidos, passando pelo resultado do PISA e currículo utilizado.

Na comparação curricular foram incluídos a estruturação educacional de cada país (como as séries são divididas), carga horária diária e anual, duração da aula e quantidade de aulas de matemática por semana. Ao término da análise, Carvalho encontra mais semelhanças do que diferenças nos currículos, evidenciando que a disparidade encontrada no resultado do PISA não leva em consideração o currículo, mas sim outros fatores, como condição socioeconômica e possível aplicação do currículo.

Ainda nos estudos comparativos entre países, temos Cerqueira (2012). Em sua tese intitulada "Um estudo comparativo entre Brasil e Chile sobre educação matemática e sua influência nos currículos de matemática desses países", o autor analisa o contexto social, político e educacional de cada país, como IDH, PIB, taxa de escolarização, contexto político, entre outros. Cerqueira realizou uma pesquisa ampla, pois os itens referentes aos contextos sociais e políticos implicam diretamente no sistema educacional de cada país.

A análise comparativa dos currículos do Brasil e Chile foi integral, isto é, Cerqueira analisou os currículos do ensino fundamental e médio do Brasil e educação primária e secundária do Chile. Entre as disparidades encontradas nos currículos, a primeira, e fundamental, é a diferença na divisão de anos entre fundamental e médio (ou primária e secundária no Chile). No Brasil temos o ensino fundamental com 9 anos e o médio com 3 anos, já no Chile os dois ciclos possuem o mesmo número, 6 anos cada.

Após uma pesquisa teórica, Cerqueira elencou seis categorias de análise dos currículos: 
1. O papel da Matemática na formação dos alunos brasileiros e chilenos;

2. Com relação à forma de estruturar o currículo prescrito;

3. Ênfase nas aplicações práticas ou nas especulações teóricas;

4. Com relação à seleção de conteúdo;

5. Com relação a orientações metodológicas e didáticas;

6. Com relação a indicações sobre o processo de avaliação da aprendizagem. (CERQUEIRA, 2012, p. 110)

Além da análise dos documentos oficiais, o autor entrevistou diretores, professores e responsáveis pela elaboração dos documentos oficiais em cada país. Com isso, Cerqueira elaborou uma correlação com os dados encontrados na análise dos documentos.

Sobre os documentos oficiais brasileiros, Cerqueira afirma que, diferentemente do Chile, no Brasil o Ministério da Educação não define qual o documento oficial, prescrito e aplicável para que os professores utilizem.

Segundo os professores brasileiros entrevistados, outra questão que deve ser observada é a discrepância do conteúdo dos livros didáticos do ensino médio em relação aos documentos oficiais. Nos livros é possível encontrar conteúdos não existentes nos $\mathrm{PCNEM}_{+}{ }^{4}$, como números complexos, funções modulares e funções inversas.

Mesmo com as diferenças na organização e distribuição dos conteúdos ao longo de todo o período educacional analisado, não houve diferenças na listagem de conteúdo. Porém a carga horária anual difere nos dois países, sendo que no Chile é de 1680 horas/aula, enquanto no Brasil pode-se chegar em até 1000 horas/aula.

Ao término de sua tese, Cerqueira observa a importância das experiências de diretores, professores e toda educação matemática na criação dos documentos oficiais.

Rosembaum (2014), em sua tese "Estudo comparado sobre a Educação Matemática presente em currículos: Brasil e Uruguai”, também analisa e compara currículos dos países em questão, além de levantar questões sociais, econômicas e políticas, para, assim, concluir com maior precisão a importância de cada currículo em seu país.

\footnotetext{
${ }^{4}$ Orientações educacionais complementares do ensino Médio
} 
Durante sua pesquisa, a autora analisa os documentos oficiais de cada país por completo, iniciando por sua criação e continuando com os objetivos e finalidades, seleção e organização dos conteúdos propostos, recursos didáticos, modelos de avaliação e influências observáveis no cotidiano da educação. Todo o ciclo de educação básica foi analisado, do ensino infantil ao término do ensino médio, além de explicitar todos os blocos individualmente.

Como Cerqueira (2012), Rosembaum (2014) também entrevista profissionais ligados à Educação Matemática, desde responsáveis pela elaboração dos currículos até gestores e professores de todos os segmentos (ensino fundamental, ensino médio e licenciatura em matemática). O objetivo das entrevistas é semelhante ao de Cerqueira, que é encontrar correlações entre o currículo e prática docente, incluindo pesquisas e possíveis influências nas concepções que norteiam as práticas educacionais.

A autora encontra semelhanças nos currículos do Brasil e Uruguai, nos conteúdos propostos e ciclos de ensino, mas também diferenças importantes, como o objetivo final do ensino básico. No Brasil é visível a preocupação em formar profissionais para o mercado de trabalho, enquanto no Uruguai a personalização da trajetória estudantil possibilita uma melhor preparação para o nível superior.

Rosembaum conclui sua tese com alguns questionamentos intrigantes, como:

Será que os jovens que concluem a última etapa da Educação Básica no Brasil aprendem efetivamente algo com essa enorme grade de disciplinas? Como deixar de discutir o fracasso da formação que oferecemos a estes brasileiros? Até mesmo se cumpríssemos adequadamente o quesito propedêutico, é comum a crítica de professores que lecionam em cursos superiores sobre a má formação dos ingressantes em suas turmas.

E a formação para o trabalho? $E$ a quantidade de empresas que não compreendem a má formação do jovem que ingressa no mercado de trabalho? $\mathrm{O}$ que estamos fazendo efetivamente nas escolas públicas em especial? (ROSEMBAUM, 2014, p.349)

É evidente que a educação brasileira ainda não está no nível desejado, muito pela atitude política de baixo investimento, e de não garantias de melhoras significativas, como a própria autora conclui. 
o aprendizado dos alunos está ruim e que a "culpa" é do professor e do baixo prestígio docente. (ROSEMBAUM, 2014, p.347)

Atualmente tem crescido os estudos comparados na educação, pois a comparação na área educacional é uma ferramenta valiosa, com ela é possível olhar em outras direções, analisar semelhanças e diferenças para, assim, aprender e evoluir sempre que necessário. Pensando nesse quesito, uma análise comparativa é o ideal para o modelo de pesquisa deste trabalho. 


\section{ANÁLISE DE LIVROS DIDÁTICOS}

Durante os últimos 20 anos, diversos autores trabalharam com a análise de livros didáticos, seja ela voltada para a verificação da qualidade de uma obra, comparação entre coleções ou verificação dos conteúdos propostos, investigando sua similaridade com os documentos oficiais. Neste capítulo examinaremos alguns trabalhos com esses aspectos, e como seus resultados são significativos na área educacional.

A importância do livro didático é tema de diversos trabalhos na última década, como o artigo de Frison et al (2009), apresentado no VII encontro nacional de pesquisa em educação em ciências. Nele, os autores salientam que os livros didáticos são a principal, e muitas vezes única fonte de trabalho na sala de aula. Logo, sua importância é inestimável no ensino-aprendizagem.

Ao analisar qual a importância atribuída ao livro didático pelos professores na preparação e desenvolvimento de suas aulas e quais suas contribuições na formação dos estudantes percebe-se que ele se constitui em um dos materiais didáticos e, como tal, passa e ser um recurso facilitador da aprendizagem e instrumento de apoio à prática pedagógica. (FRISON et al, 2009, p.4)

Outro entusiasta do livro didático é Batista (1999). Para ele, o livro didático possui diversas funções em sala de aula, como no papel de um instrumento de aprendizado do aluno, como organizador do trabalho do professor, como complemento do trabalho já realizado em sala ou como objeto para aprofundar temas e propor exercícios ou atividades.

O autor Alain Choppin (2004), em seu artigo "História dos livros e das edições didáticas: sobre o estado da arte", publicado na revista Educação e Pesquisa, salienta o interesse dos pesquisadores e historiadores nas coleções didáticas, principalmente a partir da década de 80 . Durante a obra, Choppin enumera diversas problemáticas para a pesquisa e análise de livros didáticos, como a própria definição do objeto, já que em muitas línguas o termo "livro didático" pode ser designado de diversas maneiras diferentes. 
Outra dificuldade é a carência de produções na área. Raros artigos encontrados abrangem toda uma produção didática ou período, e isso é consequência de uma terceira dificuldade: a inflação de publicações. Em 1996, só no Brasil, aproximadamente $61 \%$ dos livros publicados foram didáticos, tornando inviável uma discussão em larga escala. A última dificuldade ressaltada por Choppin é a barreira linguística, já que a utilização de livros didáticos é onipresente pelo mundo. Logo, trabalhos são publicados nas mais diversas línguas, e mesmo com uma tradução quase imprescindível para o inglês, muito se perde ao não acompanhar na língua original.

Mesmo com diversas dificuldades, professores brasileiros pesquisam e analisam coleções didáticas. Ao analisá-las, compreender a visão dos autores das obras é fundamental e, como exemplo da análise da criação de livros didáticos, temos a dissertação de Vorpagel (2008), intitulada "Livro didático de matemática: Perspectivas de sua criação pelos autores". Essa pesquisa possui o objetivo de investigar os procedimentos utilizados pelos autores de livros didáticos na criação de suas obras, tais como seleção, distribuição e estrutura dos conteúdos presentes em toda a obra.

Para iniciar seu trabalho, a autora define o que é um livro didático e, para isso, utiliza definições de Bittencourt (2004), Richaudeau (1981), Gérard e Roegiers (1998) e documentos oficiais, como PCN e PNLD. Com isso definido, Vorpagel inicia a análise do procedimento de criação de um livro didático, utilizando como parâmetro as seguintes funções: concepção, edição, avaliação e utilização.

Segundo a própria autora, a concepção "é o processo de elaboração de um manuscrito que vai desde 0 ato intelectual que antecede a redação até a própria redação" (Vorpagel, 2008, p. 30). A edição é uma etapa mais complexa, dividida em outras quatro etapas, concepção, produção, financiamento e difusão da obra, como salienta a autora.

Na concepção, o editor é quem pode orientar o trabalho dos autores no que se refere à qualidade da obra, entregando os manuscritos a uma comissão de leitura ou de avaliação para emitir pareceres científicos e pedagógicos, assegurando leituras formais quanto a aspectos mais técnicos.

Produção (encadernação) - O editor é o responsável pela qualidade de produção do manual. É ele quem redige o caderno de encargos para a tipografia, onde constarão as especificações técnicas (formato, tipo do 
papel, de encadernação, tiragem...) do trabalho de impressão. Financiamento - O editor deve equilibrar a realização de uma coleção didática no quadro de um orçamento limitado que integre todos os elementos de custo. Em alguns casos, isso o levará a orientar alguns aspectos da concepção em direções mais generosas a fim de poder fixar o preço de venda da obra a um nível aceitável.

Difusão - Após a impressão do manual, convém pô-lo à disposição dos utilizadores (em geral, professores e alunos). A difusão do material vai do simples encaminhamento do manual, único e gratuito à colocação no mercado de um manual que os utilizadores poderão adquirir numa livraria. (VORPAGEL, 2008, p. 30)

$\mathrm{Na}$ avaliação, os professores e alunos experimentam a coleção, utilizando condições reais de uso e sempre com uma amostra significativa de pessoas. Além dos professores e alunos (também chamados de destinatários), o próprio autor, juntamente com especialistas da disciplina, avalia a utilização do livro, reconhecendo possíveis efeitos nos professores, alunos, pais e demais profissionais de ensino. $\mathrm{O}$ último processo, utilização, o material é recebido pelo público, isto é, escolas, professores e alunos, e é aplicado em salas de aula.

Após compreender um pouco sobre a criação dos livros didáticos, Vorpagel realiza entrevistas com oito autores de coleções didáticas aprovadas pelo PNLD de 2008, para, assim, aprofundar nos conceitos e compreender ainda mais a importância da escolha de uma coleção para aplicação em sala de aula.

Em 2015, três mestrandos do programa PROFMAT5 realizaram suas dissertações utilizando como tema a análise de livros didáticos. Escolheram juntos uma coleção de livros didáticos de matemática para o ensino médio aprovada pelo PNLD e, após uma pesquisa teórica em conjunto, cada um analisou um volume dessa coleção.

Conceição (2015), Guimarães (2015) e Candeias (2015) analisaram os volumes 1, 2 e 3, respectivamente, da coleção Matemática: Ciência e aplicações $7^{\text {a }}$ edição, de lezzi et al, lançado em 2013. A análise foi completa, contemplando todas as áreas da matemática, além de áreas técnicas como sumário, divisão dos conteúdos, utilização de imagens, formatação e possíveis equívocos por parte do autor.

\footnotetext{
${ }^{5}$ Mestrado Profissional em Matemática
} 
Ao término dos trabalhos é verificado um consenso, pois em todos os volumes o conteúdo é exposto de forma direta, sem contextualizações. A obra como um todo possui muitos exemplos e exercícios resolvidos, conhecimento histórico (porém algumas vezes sem fonte) e apêndices com demonstrações de algumas fórmulas. Todos os autores concluem que a obra é satisfatória e bem organizada.

Dassie e Baptista (2014) também analisaram livros didáticos, porém com um enfoque diferenciado, optaram por investigar obras de um mesmo autor, Jacomo Stávale ${ }^{6}$. Além de suas obras, os autores também aprofundaram em sua vida pessoal e carreira.

$\mathrm{Na}$ análise dos livros, Dassie e Batista salientam o chamado "sistema de notas", algo presente em todas as obras analisadas de Stávale. Esse sistema é amplamente conhecido nos dias atuais, pois trata-se de textos com fontes menores, cores diferentes e separados do restante do texto, muitas vezes contendo dicas, perguntas frequentes, informações adicionais ou curiosidades.

Nas obras de Stávale, as notas mais frequentes são: (i) notas de rodapé, com informações complementares, referências ou orientações; (ii) observações ou sugestões, semelhantes às notas de rodapé, mas em locais mais diversificados; (iii) dinâmica de classe, com atividades recomendadas; (iv) recursos didáticos que, como o próprio nome sugere, se relaciona com a utilização de outros recursos, como compasso, esquadro e transferidor; ( $v$ ) notas de exercícios, com orientações e recomendações para realização dos mesmos; (vi) relação da matemática com o meio social, no qual o autor relaciona o conceito matemático com o cotidiano do estudante; (vii) referências bibliográficas, com fontes das informações apresentadas; (viii) seleção e distribuição de conteúdo, com indicações de informações dos volumes anteriores, ou série anterior. Todas essas informações são imprescindíveis aos professores, pois norteiam o andar das aulas.

Como conclusão, os autores enfatizam a importância desse modelo utilizado por Stávale, já que ainda é altamente utilizado nos dias atuais, tanto no material do professor como no próprio livro didático.

${ }^{6}$ Jacomo Stávale, professor de matemática e autor de livros didáticos brasileiro. 
Compreendendo melhor as pesquisas passadas, é possível nortear nosso trabalho, utilizando, assim, ideias e conceitos de autores já destacados e criando um planejamento adequado para prosseguimento da pesquisa. 


\section{CONSTRUÇÃO GEOMÉTRICA}

Ao analisar o conteúdo de construção geométrica ${ }^{7}$ (ou desenho geométrico) nos livros didáticos devemos compreender sua história e importância na matemática atual, pois assim evidenciaremos pontos relevantes do seu estudo e o tratamento dado pelas obras selecionadas.

Sabemos que existe diferenças entre os termos construção geométrica e desenho geométrico. Zuin (2001) diferencia o ato de construir e desenhar de modo que o desenho é a reprodução de uma imagem geométrica, enquanto a construção remete as propriedades e elementos do objeto, vai além de um simples desenho.

\subsection{Contexto histórico}

O conceito de construção geométrica é antigo, data aproximadamente no século V a.C., na Grécia. Para os gregos, construção geométrica e geometria eram conhecimentos associados, sendo inviável o estudo desvinculado, pois tratam-se como complementares, já que os problemas, ou situações geométricas, eram, em diversos casos, solucionados com a utilização da construção geométrica (ou desenho geométrico).

Por volta de 300 a.C., Euclides ${ }^{8}$ elaborou sua obra Elementos, um epítome do conhecimento geométrico da época. Nela observamos a geometria de forma elaborada, dividida em postulados, axiomas e proposições que mudaram a forma que a matemática era vista até o momento, mantendo-se relevante até os dias atuais.

Em seus postulados, Euclides restringe a utilização de ferramentas a apenas régua sem escala e compasso, assim, esses instrumentos tornaram-se conhecidos

${ }^{7}$ Ao longo do trabalho utilizaremos construção geométrica e desenho geométrico como sinônimos, pois cada obra utiliza um termo diferente. Sabemos que alguns autores optam por apenas uma nomenclatura, mas por questões de análise das obras, escolhemos por manter as duas opções.

8 Euclides de Alexandria, mestre, escritor de origem provavelmente grega, matemático da escola platônica, e conhecido como o Pai da Geometria, nasceu na Síria aproximadamente em 330 a.C. e realizou seus estudos em Atenas. 
por instrumentos euclidianos. Essas construções envolvendo régua e compasso eram tratadas como jogos para os gregos, tendo apenas duas regras.

Com a régua permite-se traçar uma reta de comprimento indefinido passando por dois pontos distintos dados. Com o compasso permite-se traçar uma circunferência com centro num ponto dado passando por um segundo ponto qualquer dado. (EVES, 2007, p.134)

Ao utilizar os instrumentos euclidianos é possível realizar diversas operações e construções geométricas, como: adição, subtração, multiplicação e divisão de segmentos; criação de retas paralelas e perpendiculares; bissectar um ângulo; localizar incentro, ortocentro, circuncentro e baricentro; construção de polígonos regulares; solucionar alguns problemas algébricos.

Com ampla utilização prática, a construção geométrica (ou desenho geométrico) ganha espaço no cotidiano da humanidade. No século XII as universidades da Europa utilizavam a obra de Euclides nas aulas de aritmética e geometria. As Corporações de Ofício (associações de artesões e comerciantes) da Europa também utilizavam o desenho geométrico como um dos instrumentos de seus manuais, intitulados "livros de receitas".

Valente, em seu livro "Uma história da matemática escolar no Brasil (17301930)", evidencia a importância da matemática nessa época:

Desde a época medieval, a matemática passou a ser vista predominantemente como um conhecimento útil para as chamadas "artes mecânicas", um conhecimento prático. A geometria representava um dos elementos necessários aos carpinteiros, aos arquitetos e aos agrimensores e a aritmética constituía a base principal da "arte do comércio". (VALENTE, 2007, p.40)

Durante o Renascimento (movimento artístico e científico), o estudo dos filósofos gregos é retomado e, dentro dele, o conceito de geometria de suas obras. No âmbito artístico, a geometria é ligada ao perfeccionismo. Com isso, diversos pintores da época empregavam seus conceitos em técnicas de perspectiva.

Entre os artistas, arquitetos e matemáticos que utilizavam técnicas de geometria ou desenho geométrico na época, temos: Brunelleschi ${ }^{9}$ (1377-1446), que em 1425 formalizou um sistema matemático de perspectiva; Francesca ${ }^{10}$ (1415-

\footnotetext{
${ }^{9}$ Filippo Brunelleschi, arquiteto e escultor italiano.

${ }^{10}$ Piero Della Francesca, pintor italiano.
} 
1492), que utilizou o método dedutivo de Euclides para apresentar a perspectiva como uma ciência, com construções e demonstrações; Pacioli11 (1445-1517), que estudava os sólidos e a depois chamada "secção áurea"; Desargues ${ }^{12}$ (1591-1661), que compilou diversas obras sobre geometria e desenho da época do Renascentismo para utilização de pintores, canteiros, engenheiros e arquitetos.

Para Zuin (2001), a utilização do desenho geométrico por parte de grandes pintores e arquitetos valorizam e auxiliam na divulgação dessas técnicas, tornandoas importantes nas artes e avanços técnicos.

Durante a primeira Revolução Industrial, na Inglaterra, o conhecimento em construções geométricas era utilizado na elaboração de máquinas, ferramentas e no desenho de novas vias de transporte. Gaspard Monge ${ }^{13}$ (1746-1818) utilizou da construção geométrica na elaboração dos princípios da Geometria Descritiva, estudada até os dias atuais.

Com o início da corrente de pensamento positivista, elaborada por Auguste Comte $^{14}$ (1798-1857), o desenho geométrico ganha mais destaques nas escolas, principalmente por suas características de "rigor e precisão", remetendo aos princípios positivistas, como a utilização do método científico sendo o único caminho para o conhecimento.

Após Comte, na segunda Revolução Industrial, o desenho geométrico atinge seu auge, sendo altamente valorizado e popularizado. Diversos cursos sobre o tema começaram a surgir, principalmente ligados à indústria. Na França, algumas competições de desenho aconteceram, onde estudantes-aprendizes e trabalhadores apresentavam seus trabalhos.

No Brasil, o desenho geométrico já era ensinado durante o século XVIII na faculdade de matemática de Salvador. Na disciplina de geometria era utilizado "Os elementos", de Euclides e trabalhos de Ptolomeu ${ }^{15}$. Também no mesmo século,

\footnotetext{
11 Luca Pacioli, monge e matemático italiano.

${ }^{12}$ Girard Desargues, matemático, arquiteto e engenheiro francês.

${ }^{13}$ Gaspard Monge, matemático francês.

${ }^{14}$ Auguste Comte, filósofo francês.

${ }^{15}$ Ptolomeu (ou Ptolemeu), cientista e matemático grego.
} 
nascem as aulas de Fortificação e Arquitetura Militar, onde o desenho era parte fundamental do aprendizado.

Durante o século XIX, as aulas de Fortificação e Arquitetura Militar deram espaço para a Academia Real Militar e Academia Real dos Guardas-Marinha, onde os trabalhos com desenho geométrico continuaram, mas substituindo Euclides por obras de Bézout ${ }^{16}$, Lacroix ${ }^{17}$ e Legendre ${ }^{18}$. Com a criação de cursos superiores de Arquitetura, o desenho geométrico ganhou espaço e viabilizou a utilização em outros cursos superiores, abrangendo diversas profissões.

No século $\mathrm{XX}$, com a reforma estabelecida com a portaria ministerial de 30/06/1931, o ensino do desenho geométrico tornou-se obrigatório durante o ensino fundamental, mas dividido em quatro modalidades distintas: desenho do natural, desenho decorativo, desenho convencional e desenho projetivo e do natural. Em cada modalidade era estudado alguns conceitos de desenho geométrico, além de utilizar da interdisciplinaridade.

Entre os anos de 1937 e 1945, período conhecido como Estado Novo ${ }^{19}$, aconteceu a reforma Capanema, responsável pela criação de diversas leis referentes à educação. Entre elas está a valorização da construção geométrica, já sendo iniciada no primeiro ano do novo ciclo, ginasial, estendendo-se até o final dele. Na sequência, o curso científico (ciclo posterior ao ginasial) continua apresentando obrigatoriedade do desenho geométrico durante todo o ciclo.

Com o surgimento do Movimento da Matemática Moderna ${ }^{20}$ (MMM), a geometria, e consequentemente o desenho geométrico, perde força e, posteriormente, com a LDB 5692/71, a disciplina desenho geométrico é retirada da lista de disciplinas obrigatórias no currículo, tornando-a optativa. Com isso, várias escolas excluíram o conteúdo de suas grades curriculares.

16 Éttiene Bézout, matemático francês.

17 Sylvestre François Lacroix, matemático francês.

${ }^{18}$ Adrien-Marie Legendre, matemático francês.

${ }^{19}$ Estado Novo, ou Terceira República Brasileira, foi o regime político brasileiro fundado por Getúlio Vargas em 10 de novembro de 1937, que vigorou até 31 de janeiro de 1946. Era caracterizado pela centralização do poder, nacionalismo, anticomunismo e por seu autoritarismo. É parte do período da história do Brasil conhecido como Era Vargas.

${ }^{20}$ O Movimento da Matemática Moderna foi um movimento internacional do ensino de matemática que surgiu na década de 1960 e se baseava na formalidade e no rigor dos fundamentos da teoria dos conjuntos e da álgebra para o ensino e a aprendizagem de Matemática. 
A lei de diretrizes e bases de 71 permaneceu por 25 anos, até ser substituída pela atual, lei 9394/96, e com ela a criação dos Parâmetros Curriculares Nacionais (PCN), no ano de 1998. Nos PCN a construção geométrica ganhou força, pois empregavam a utilização de ferramentas como régua, compasso, esquadros e transferidor, mas deixou de ser uma disciplina e anexou-se na matemática. Algumas escolas ainda mantém a disciplina de forma separada da matemática, como componente único, e outras tratam as construções geométricas dentro do componente de artes.

\subsection{Importância do desenho geométrico na aprendizagem}

O desenho geométrico, como o restante da grade curricular da área da matemática, possui sua importância no aprendizado do estudante. Esse aprendizado não contempla apenas conhecimentos geométricos, mas também amplia os conceitos e definições de outras áreas da matemática, como ressalta Silva (2006).

O DG (desenho geométrico) é uma linguagem da Matemática. Sem ele seria impossível o aprendizado dos conceitos, das definições e das demonstrações imprescindíveis ao entendimento das relações geométricas, principalmente, mas, também, daquelas que ocorrem em aritmética e álgebra. Exerce uma função de facilitador da compreensão dos conteúdos daquelas disciplinas e está associada a elas, é parte das mesmas. (SILVA, 2006, p.45)

Além do conhecimento acadêmico, o desenho geométrico, juntamente com a geometria como um todo, está presente no cotidiano dos estudantes, nos objetos e no mundo, como diz Dante (2002).

[...] tudo o que nos rodeia lembra formas geométricas, basta olharmos os objetos que nos cercam. Vivemos em um mundo de formas geométricas. Elas constituem um mundo de diversidades e podem ser constatadas nas artes, na natureza, nas construções, etc. (DANTE, 2002, p.89)

Segundo Zuin (2001), houve nas últimas décadas uma preocupação com o ensino de construções geométricas, pois, além de auxiliar na própria geometria, colabora com o desenvolvimento cognitivo da criança, auxiliando na coordenação motora e visual e compreensão mais rápida de gráficos, mapas e demais informações visuais. 
Putnoki (1991), autor do livro Elementos de Geometria e desenho geométrico, levanta duas perguntas importantes: "Para quem serve o desenho geométrico" e "Para que serve o desenho geométrico?" O próprio autor responde em seu livro.

\section{Para quem serve desenho geométrico?}

A resolução de um problema de construção geométrica, de modo geral, compreende duas etapas: A pesquisa das propriedades e da sequência de operações que possibilitam realizar a construção e a execução da construção pedida, servindo-se dos instrumentos de desenho.

[...] na primeira etapa lidamos, de forma teórica, com os elementos de Geometria, exigindo-se dos estudantes muito empenho. $O$ estudo do desenho, nessa fase, dará oportunidade de desenvolver o raciocínio lógicodedutivo, além de despertar a criatividade. Independentemente da área a que vá se dedicar futuramente como profissional, o estudante terá aí um elemento fundamental na sua formação.

Na segunda etapa, quando se manuseiam os instrumentos, desenvolve-se gradualmente o sentido de organização, ao ver se concretizarem, no papel, as ideias que possibilitam a construção. Especificamente os que pretendem orientar seus estudos para as áreas de engenharia ou arquitetura terão o desenho geométrico o instrumental necessário ao desenho projetivo, que, por sua vez será muito utilizado nessas profissões. (POTNOKI, 1991, p. 8-9)

Para que serve desenho geométrico?

O desenho geométrico é classificado como desenho resolutivo, pois através dele, determinam-se respostas precisas para problemas de natureza prática ou teórica.

[...] impelir o estudante a aperfeiçoar seu raciocínio lógico, a desenvolver sua criatividade e a aguçar seu senso de organização. (POTNOKI, 1991, p.9)

É perceptível que o desenho geométrico é muito mais que apenas um ramo da geometria e, consequentemente, da matemática. O seu uso está conectado com o cotidiano e vinculado com diversas áreas do conhecimento. Aprender desenho geométrico auxilia na cognição e coordenação motora. Em razão disso, é importante ser aplicada aos estudantes.

Além disso, é necessário compreender a evolução na construção geométrica. $\mathrm{Na}$ Antiguidade, as ferramentas utilizadas eram régua não graduada e compasso, exclusivamente. Com o passar do tempo, os avanços matemáticos e tecnológicos permitiam a utilização de diversas outras ferramentas, e isso não desvalorizava a construção em si. 
Um aluno que utiliza esquadros para desenhar um quadrilátero também utilizou de construção geométrica, não a tradicional abordada por Euclides, mas desfrutou das ferramentas que possui para construir algo desejado, utilizando conceitos geométricos adequados. Nessa análise levamos em consideração tais construções, mesmo não sendo classificadas como construções geométricas clássicas.

\subsection{Softwares de geometria dinâmica}

É inegável que a tecnologia tenha se tornado parte fundamental do nosso cotidiano. Com isso, a sua utilização como ferramenta educacional cresce a cada dia, fortalecendo, assim, o processo de ensino-aprendizagem de uma geração já habituada com tais tecnologias. O uso de softwares de geometria dinâmica contribui na superação de diversas dúvidas recorrentes da geometria, pois contraria as ferramentas básicas, como lousa, caderno e apostila. Já o software possui dinamismo, no qual o estudante tem liberdade para testar, explorar e teorizar sobre o acontecido na tela.

A inserção de tecnologia no ensino-aprendizagem também contribui na motivação e no interesse do estudante, estimulando, assim, seu desejo em realizar não só as tarefas base, mas também questionar resoluções, pesquisar diversos meios para alcançar um objetivo e criar suas próprias soluções.

O interesse de adicionar a tecnologia nas aulas de matemática não é recente, nos próprios PCNs já encontramos citações da importância da utilização de softwares como ferramenta de ensino: "...como meio para desenvolver autonomia pelo uso de softwares que possibilitem pensar, refletir e criar soluções" (BRASIL, 1998).

Segundo o Guia dos Livros Didáticos de 2017, a utilização dos softwares auxilia na mobilidade de figuras e modelos geométricos, item impossível no tradicional lápis e papel ou mesmo com lousa e giz.

Atualmente, as múltiplas possibilidades oferecidas pelos softwares de geometria dinâmica e de computação gráfica permitem gerar imagens gráficas de modelos matemáticos e possibilitam a sua movimentação. Essa mobilidade é impossível com papel e lápis, com instrumentos de desenho ou com imagens fotográficas. Em que pese a alta qualidade das imagens 
produzidas no computador, é preciso levar em conta que todos esses recursos não produzem objetos matemáticos e, sim, representações desses objetos por meio de imagens gráficas. (BRASIL, 2016, p.8)

Escolher qual software se adequa melhor para cada estudante ou classe é um trabalho necessário pois, atualmente, existem diversos softwares de geometria dinâmica, cada qual com suas funções. Alguns dos mais conhecidos são: Cabri Géomètre $^{21}$, software pago disponível para as plataformas Windows e MacOS; Geogebra $^{22}$, software gratuito disponível para as plataformas Windows, MacOS, Linux, iOS e Android, sendo as duas últimas plataformas de dispositivos móveis; C.a.R. ${ }^{23}$ (Compass and Ruler), software gratuito para plataforma Windows; Tabulae ${ }^{24}$, software gratuito para plataforma Windows.

A introdução dessa tecnologia deve ser cuidadosa, pois além da compreensão dos conceitos matemáticos, o estudante deve dominar o software, conhecer suas funções, configurações e manuseio de objetos. O professor possui um papel de mediador entre estudante e software, auxiliando sempre que necessário, mas sem obstruir o autoconhecimento do aluno.

${ }^{21}$ Disponível em: http://www-cabri.imag.fr/

${ }^{22}$ Disponivel em: https://www.geogebra.org/

${ }^{23}$ Disponível em: http://car.rene-grothmann.de/

${ }^{24}$ Atualmente sem página oficial, disponível para download em páginas de terceiros, como: https://sites.google.com/site/wellersonquintaneiro/software-de-grafico 


\section{DOCUMENTOS OFICIAIS DO BRASIL E CANADÁ}

Para uma análise coerente dos livros didáticos, é necessário compreender os documentos oficiais nos quais os livros se baseiam. Atualmente, no Brasil, o documento federal que estabelece uma referência curricular comum em todo o território nacional é chamado BNCC (Base Nacional Comum Curricular). Entretanto, os livros didáticos brasileiros utilizados para análise são anteriores a esse documento, então utilizavam como currículo nacional os PCN (Parâmetros Curriculares Nacionais).

\subsection{Parâmetros curriculares nacionais}

Elaborado no contexto da reforma educacional da década de 1990, a lei de Diretrizes e Bases da Educação Nacional (Lei Federal no 9394/96) substituiu a antiga lei federal $\mathrm{n}^{0}$ 5692/71. A reforma teve como base a Conferência Mundial de Educação para Todos, que ocorreu em Jomtien, na Tailândia, em 1990. Tal conferência foi organizada pelo Banco Mundial, junto com UNESCO ${ }^{25}$, UNICEF ${ }^{26}$ e PNUD $^{27}$, com intuito de universalizar o acesso à educação e promover a equidade.

Segundo a LDB (Lei de Diretrizes e Bases), de 1996, o principal objetivo desta reforma é a boa convivência entre os cidadãos:

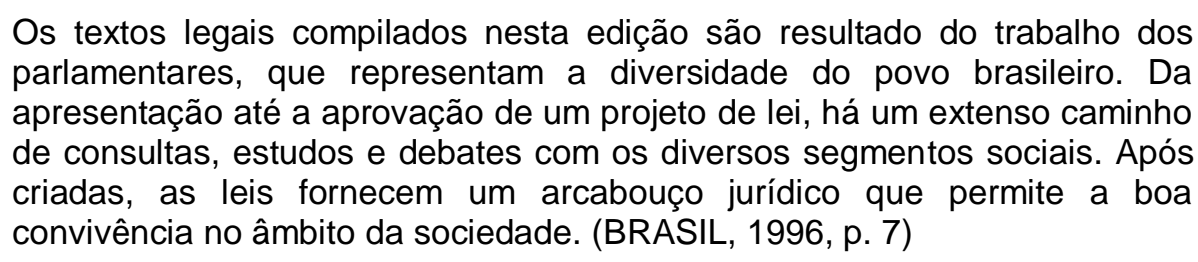

Com o respaldo legal da LDB, a elaboração do PCN ganhou força. O estudo das propostas curriculares dos estados e municípios, juntamente com a experiência em diversos países, auxiliou na realização do documento, que em 1998 ganhou sua versão final.

\footnotetext{
25 Organização de Educacional, Científica e Cultural das Nações Unidas

${ }^{26}$ Fundo das Nações Unidas para a Infância

27 Programa das Nações Unidas para o Desenvolvimento
} 
O documento não é um currículo estático, mas sim serve como "parâmetro", como o próprio nome supõe. Cada estado e município possui um currículo próprio, baseando-se no PCN, como consta no documento:

Os Parâmetros Curriculares Nacionais constituem, portanto, um referencial para fomentar a reflexão, que já vem ocorrendo em diversos locais, sobre os currículos estaduais e municipais. O conjunto das proposições, expressas nos Parâmetros Curriculares Nacionais, tem como objetivo estabelecer referenciais a partir dos quais a educação possa atuar, decisivamente, no processo de construção da cidadania. (BRASIL, 1998, p.50)

Os professores e a equipe pedagógica também possuem a flexibilidade no momento da elaboração do currículo utilizado, como salienta o documento:

\begin{abstract}
Os Parâmetros Curriculares Nacionais configuram uma proposta aberta e flexível, a ser concretizada nas decisões regionais e locais sobre currículos e sobre programas de transformação da realidade educacional empreendidos pelas autoridades governamentais, pelas escolas e pelos professores. Não configuram, portanto, um modelo curricular homogêneo e impositivo, que se sobreporia à competência dos estados e municípios, à diversidade política e cultural das múltiplas regiões do país ou à autonomia de professores e equipes pedagógicas. (BRASIL, 1998, p. 50)
\end{abstract}

O conjunto de documentos intitulados PCN são subdivididos em três categorias: anos iniciais do fundamental (antigo $1^{\underline{a}}$ a $4^{\underline{a}}$ séries), anos finais do ensino fundamental (antigo $5^{\underline{a}}$ a $8^{\underline{a}}$ séries) e ensino médio. Em cada categoria ainda existe diversos volumes, subdivididos em introdução, disciplinas e temas transversais.

A disciplina matemática referente aos anos finais do ensino fundamental, nos PCN, está dividida em quatro blocos: Números e operações; Espaço e forma; Grandezas e medidas; Tratamento da informação.

Segundo o próprio documento, a geometria é importante em diversos aspectos, incluindo o social e na criação das capacidades cognitivas fundamentais. "O estudo da geometria é um campo fértil para trabalhar com situações-problema e é um tema que os alunos costumam se interessar naturalmente" (BRASIL, 1998, p.51)

Ao solucionar problemas envolvendo geometria, o aluno terá um primeiro contato com o raciocínio dedutivo, mas isso não caracteriza um tratamento exclusivamente axiomático da geometria. 
No desenvolvimento de conteúdos referentes à geometria e medidas, os alunos terão também oportunidades de identificar regularidades, fazer generalizações, aperfeiçoar a linguagem algébrica e obter fórmulas, como para os cálculos das áreas. (BRASIL, 1998, p.118)

O campo da geometria aparece em dois blocos: Espaço e forma; Grandezas e medidas. No bloco "Espaço e forma" temos construções geométricas como conteúdo para os anos finais do ensino fundamental:

O trabalho com espaço e forma pressupõe que o professor de Matemática explore situações em que sejam necessárias algumas construções geométricas com régua e compasso, como visualização e aplicação de propriedades das figuras, além da construção de outras relações. (BRASIL, 1998, p.51)

Nesse ponto, o documento aborda a construção geométrica usual, com régua e compasso, mas durante o trabalho utilizaremos uma visão mais ampla, acrescentando outras ferramentas.

As atividades geométricas no ensino fundamental possuem como foco os procedimentos de observação, representação e construção de figuras, utilizando, assim, instrumentos para verificação de propriedades. Tais procedimentos privilegiam o pensamento lógico e crítico, e não apenas simples memorizações de resoluções.

Os PCNs apresentam os conteúdos divididos por anos do ensino fundamental, subdividido em dois períodos: terceiro ciclo (atuais $6^{\circ}$ e $7^{\circ}$ anos) e quarto ciclo (atuais $8^{\circ}$ e $9^{\circ}$ ano). No terceiro ciclo observamos a utilização de diversos instrumentos, como transferidor, esquadro, régua e compasso. Com isso, os alunos compreendem as relações entre procedimentos e propriedades geométricas.

No terceiro ciclo do ensino fundamental temos as construções com régua e compasso como aspecto importante, sendo ressaltado pelo próprio documento.

Outro aspecto que merece atenção neste ciclo é o ensino de procedimentos de construção com régua e compasso e o uso de outros instrumentos, como esquadro e transferidor, estabelecendo-se a relação entre tais procedimentos e as propriedades geométricas que neles estão presentes. (BRASIL, 1998, p. 68) 
Nesse momento o documento já abrange os procedimentos de construção, acrescentando outras possíveis ferramentas, visão semelhante a utilizada neste trabalho.

Os procedimentos de construção não devem se distanciar dos demais conteúdos matemáticos, sempre deve-se trabalhar com ligações entre os outros conteúdos ministrados, ressaltando sua importância na visão geral.

Construção geométrica também está presente nos critérios de avaliação para o terceiro ciclo dos PCNs, "analisar, classificar e construir figuras geométricas bidimensionais e tridimensionais, utilizando as noções geométricas como ângulos, paralelismo, perpendicularismo, estabelecendo relações e identificando propriedades". (BRASIL, 1998, p.77)

No quarto ciclo, os PCNs apontam diversas ocasiões em que os instrumentos geométricos podem ser utilizados para a "construção" dos conceitos, como: $\mathrm{Na}$ compreensão de números irracionais, localizando-os na reta numérica com o auxílio das ferramentas em questão; Inserido no campo da geometria com as construções de retas paralelas e perpendiculares, divisão de segmentos em partes proporcionais, obtenção de mediatriz e bissetriz de ângulos e construção das alturas, bissetrizes, medianas e mediatrizes de um triângulo.

Mesmo com a sugestão dos PCNs para os professores, isso não garante a sua utilização em sala de aula pois, segundo o próprio documento, o professor deve analisar cada conteúdo e definir qual ênfase cada item necessita. Além disso, as diferenças regionais e culturais são levadas em consideração nesse momento.

Com isso, o documento oficial oferece questões para que o professor possa trabalhar em sala de aula, tornando sua responsabilidade compreender quais itens são mais relevantes para o grupo de alunos.

Além dos PCNs, os livros didáticos brasileiros baseiam-se no edital do guia do livro didático, documento criado pelo PNLD (Programa Nacional do Livro didático). 


\subsection{Guia do livro didático}

A história sobre os programas de livros didáticos iniciou-se no Brasil, em 1929, com a criação do Instituto Nacional do Livro Didático (INL), mas apenas em 1938, com a criação da Comissão Nacional do Livro Didático (CNLD), iniciaram a política de legislação e controle da produção e circulação dos livros didáticos em território nacional.

Ao longo dos anos algumas alterações foram realizadas, como em 1945, por meio do decreto-lei № 8.460, que consolida algumas condições de produção dos livros e restringe o professor a fazer a escolha do livro didático que os alunos utilizarão.

No ano de 1966 houve um acordo entre o Ministério da Educação (MEC) e a Agência Norte-Americana para o Desenvolvimento Internacional (Usaid), criando, assim, a Comissão do Livro Técnico e Livro Didático (Colted). Com isso, foi possível distribuir gratuitamente 51 milhões de livros didáticos em todo o país.

Em 1971, o INL desenvolve o Programa Do Livro Didático para o Ensino Fundamental (Plidef), assumindo, assim, as atribuições administrativas e financeiras, encerrando o convênio entre MEC e Usaid. Ainda na década de 70, precisamente no ano de 1976, por meio do decreto ํㅜ 77.107 , o governo assume a compra de boa parcela dos livros didáticos para distribuição.

Com a extinção do INL no ano de 1976, fica a cargo da Fundação Nacional do Livro didático (Fename) a execução do programa do livro didático. Os recursos necessários provêm do Fundo Nacional de Desenvolvimento da Educação (FNDE), mas como são insuficientes, a grande maioria das escolas municipais deixa de participar do programa.

No ano de 1985 é criado o Programa Nacional do Livro Didático (PNLD), substituindo, assim, o Plidef. Junto dele, acompanha-se algumas mudanças, como a reutilização dos livros, fim da participação financeira dos estados e indicação do livro didático pelo professor. 
Em 1996 é publicado o primeiro Guia de Livros Didáticos, contemplando de $1^{\text {a }}$ a 4⿳亠丷厂 série. A partir disso, a cada ano é publicado um novo guia, cada qual com seu ciclo específico: anos iniciais do fundamental; anos finais do fundamental; ensino médio.

O último guia do livro didático publicado foi referente aos livros aprovados para o ano de 2017, englobando os anos finais do fundamental (6ำ ao 9ำ ano). Todas as coleções aprovadas são analisadas segundo o edital de convocação para o processo de inscrição e avaliação de obras didáticas para o programa nacional do livro didático (edital de convocação 02/2015 - CGPLI). No edital encontram-se diversos itens de caráter eliminatório, nos quais as editoras e autores baseiam-se na elaboração do livro didático.

As obras são inscritas de duas formas distintas. As obras do tipo 1 contém o livro impresso do estudante, manual do professor impresso e manual do professor multimídia. As obras tipo 2 possuem apenas as versões impressas do livro do estudante e do manual do professor.

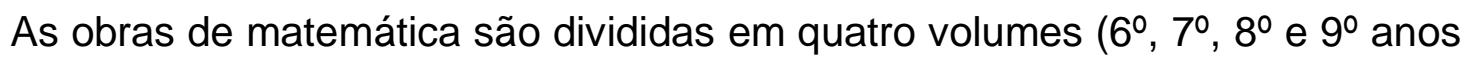
do ensino fundamental), sendo que o número máximo de páginas por volume é de 400 páginas para o livro do aluno e 512 para o livro do professor (contendo livro do aluno e manual do professor).

Para ser aprovado, a coleção é submetida a diversas etapas, iniciando-se pela triagem, na qual consiste na verificação dos atributos físicos, editoriais e documentais, todos passíveis de exclusão da obra caso não se adeque. Cada coleção também é submetida à análise preliminar para cada componente curricular. As coleções de matemática são sujeitas a doze critérios eliminatórios, além dos critérios comuns para todas as áreas.

Após a qualificação, as obras são publicadas no guia do livro didático, contendo uma visão geral da obra, uma breve descrição, os conteúdos abordados em cada volume, análise contendo a distribuição dos campos da matemática por volume e manual do professor. 
Além das coleções aprovadas, o guia do livro didático traz as principais características para cada campo da matemática: números e operações; álgebra; geometria; grandezas e medidas; estatística e probabilidade.

No campo da geometria é evidenciada a importância da construção geométrica com instrumentos de desenho, pois torna a aprendizagem mais eficiente:

\begin{abstract}
Na busca de tornar mais efetiva a aprendizagem da geometria as obras têm recorrido a atividades de visualização e de construções geométricas com instrumentos de desenho ou com materiais para manuseio. Com isso, espera-se que o estudante não seja desestimulado por um ensino muito teórico e que aprenda com mais autonomia. No entanto, é necessário cuidado para garantir equilíbrio entre essas atividades experimentais, tão importantes, e a formação do raciocínio dedutivo no campo de geometria. (BRASIL, 2016, p.36)
\end{abstract}

As construções são extremamente importantes, pois possibilitam que o estudante tenha uma maior familiaridade com as figuras geométricas e suas propriedades, além de validar diversos teoremas euclidianos. No guia dos livros didáticos de 2017 "constata-se que algumas obras apresentam construções geométricas sem mostrar porque elas são corretas, ou seja, porque elas podem ser justificadas" (BRASIL, 2016, p.39).

A utilização da construção geométrica juntamente com suas ferramentas e instrumentos, como régua, compasso e esquadro, são destacadas em quase todas as obras aprovadas pelo PNLD 2017, porém "na maioria das coleções, as construções são apresentadas como uma sequência de etapas sem as necessárias justificativas apoiadas nas propriedades das figuras geométricas" (BRASIL, 2016, p.51).

\title{
5.3 The Ontário Curriculum
}

O Canadá, por tratar-se de um país continental, subdivide o território em províncias, sendo que cada uma delas é responsável pelo seu sistema educacional. Os currículos possuem várias similaridades para que, caso seja necessária uma mudança de província, o aluno não seja penalizado.

A escolha por Ontário deu-se por três motivos: trata-se da maior província Canadense, é a localização da capital Otawa e possui como língua oficial o inglês (lembrando que o Canadá possui duas línguas oficiais: inglês e francês). 
Entre os principais princípios que guiam o documento é ressaltado a diversidade do estudo da matemática, sendo que todo aluno pode e merece aprender matemática, levando em consideração que cada indivíduo aprende de uma forma distinta, não existindo uma forma correta de se ensinar. Enxergar cada aluno como único é uma tarefa árdua, mas recompensadora.

Construir uma base para os anos seguintes (secondary) serve para enraizar conceitos e formalizar a estrutura lógica da matemática para, assim, usufruir posteriormente no andamento acadêmico. Para isso, além dos instrumentos tradicionais (lousa, caderno, livros didáticos, ferramentas geométricas, entre outros) é ressaltado o uso da tecnologia como suporte para um ensino contínuo e prazeroso.

As expectativas do currículo de Ontário (The Ontário Curriculum, Grades 1 to 8: Mathematics, 2005) são divididas em duas categorias: gerais e específicas. A primeira refere-se ao conteúdo que o aluno deve demonstrar ao término de cada ano, e a segunda tem relação com os conhecimentos e habilidades em cada conteúdo, sendo flexível em relação a cada grupo de estudantes.

O currículo de Ontário subdivide o conteúdo matemático em cinco vertentes. São elas: senso numérico e numeração; medidas; geometria e senso espacial; álgebra e padrões; gerenciamento de dados e probabilidade ${ }^{28}$.

Desenho geométrico aparece nas expectativas da vertente de geometria e senso espacial, juntamente com visualização e comparação de formas geométricas, formando, assim, as três características principais no desenvolvimento do senso geométrico e espacial. Investigar e reconhecer padrões e propriedades também são habilidades encontradas na vertente que podem contribuir para uma aprendizagem utilizando construções geométricas.

O papel da tecnologia é ressaltado no currículo, pois é possível criar estratégias de aprendizado diferenciadas, e o conteúdo de construções geométricas não foge disso. Com softwares específicos, é possível elaborar criações complexas e verificar suas propriedades, trazendo um caráter dinâmico para a aula.

\footnotetext{
${ }^{28}$ Tradução livre do texto: "Number Sense and Numeration, Measurement, Geometry and Spatial Sense, Patterning and Algebra, and Data Management and Probability. "
} 
Ao longo do documento, as expectativas e conteúdos matemáticos são divididos ao longo dos oito anos no elementary, sendo explicitado com detalhes em cada uma das cinco vertentes da matemática.

Durante a grade 5 , a criação de triângulos com utilização de ferramentas diversas (compasso, transferidor e softwares de geometria dinâmica) é incluída entre as expectativas da vertente de senso geométrico e espacial. Construção de ângulos de até $90^{\circ}$ também se encontra presente entre as expectativas específicas.

Na grade 6 a construção de figuras planas permanece no documento, porém com enfoque amplo, com a construção e classificação de polígonos e ângulos superiores a $90^{\circ}$. Diferente da grade 5 , essas expectativas são consideradas gerais, logo, ao término do ano letivo, o aluno deve dominar tal habilidade.

A construção geométrica é amplamente trabalhada na grade 7 . Entre os conteúdos programáticos, temos: construção de retas paralelas e concorrentes (entre elas as perpendiculares), construção e classificação de triângulos e quadriláteros e construção de bissetrizes. Todos utilizam ferramentas de apoio, indo de uma simples régua graduada a softwares de geometria dinâmica.

Durante o último ano do elementary, grade 8 , o enfoque da construção geométrica é na elaboração de círculos e circunferências e na investigação de suas propriedades.

Os conhecimentos básicos da construção geométrica estão presentes no currículo de Ontário, resta verificar se os livros didáticos estão de acordo com o documento oficial.

\subsection{The Trillium list}

Criada em 2002, a Trillium list substituiu a circular 14, de 1995, com o papel de concentrar todos os livros didáticos aprovados para uso na província de Ontário. As coleções são aprovadas pelo Ministério da Educação, como consta no documento: 
conselhos escolares podem selecionar livros didáticos da lista Trillium e aprová-los para uso em suas escolas. ${ }^{29}$ (ONTÁRIO, 2008, p.1)

Para aprovação, os livros didáticos necessitam seguir alguns critérios, divididos em duas grandes áreas: requisitos de elegibilidade e critérios de avaliação.

Podemos elencar nos requisitos de ilegibilidade os seguintes:

1 - Congruência com o currículo, ou seja, atender a um mínimo de 85\% das expectativas do documento;

2 - Estar de acordo com as políticas do Ministério da Educação;

3 - As obras precisam ser manufaturadas no próprio país e, sempre que possível, elaboradas por autores canadenses;

4 - Os livros didáticos precisam estar acompanhados de um guia do professor;

5 - Os livros didáticos precisam utilizar orientações canadenses, como citado no próprio documento.

O conteúdo deve ter uma orientação canadense. Deve reconhecer as contribuições e realizações canadenses e usar exemplos e referências canadenses quando possível. Ele deve utilizar convenções ortográficas canadenses e unidades SI (unidades de medição do Sistema Internacional de Unidades, ou Sistema Internacional de Unidades) para referências de medição. O vocabulário e os exemplos devem ser familiares para os canadenses. ${ }^{30}$ (ONTÁRIO, 2008, p.6)

$\mathrm{Na}$ segunda área, critérios de avaliação, os itens são divididos em dois grupos: conteúdo e formato. Os principais tópicos referentes ao conteúdo são:

1 - Qualidade, como relevância do conteúdo e uso de informação adequada para a série em questão;

29 Tradução livre do texto: "Textbooks that have been approved by the Minister of Education in accordance with the eligibility requirements and evaluation criteria outlined in this document are listed on the Trillium List. School boards may select textbooks from the Trillium List and approve them for use in their schools."

30 Tradução livre do texto: "The content must have a Canadian orientation. It must acknowledge Canadian contributions and achievements and use Canadian examples and references wherever possible. It must use Canadian spelling conventions and SI units (units of measurement of the Système international d'unités, or International System of Units) for measurement references. The vocabulary and examples should be familiar to Canadians." 
2 - Uso de tecnologia;

3 - Cuidados com a saúde e segurança;

4 - Responsabilidade ambiental;

5 - Nível da linguagem utilizada;

6 - Estratégias de instrução e avaliação;

7 - Material deve ser livre de qualquer conteúdo que incite preconceito, seja por raça, cultura, religião, gênero, orientação sexual, socioeconômico ou necessidades especiais.

Em formato temos dois tópicos. São eles:

1 - Adequação para o uso do estudante, já que o público alvo não é o professor;

2 - Durabilidade, pois os livros precisam ser manufaturados com matérias de qualidade.

Abaixo temos dois quadros que sintetizam as semelhanças e diferenças encontradas nos quatro documentos oficiais.

\begin{tabular}{|l|l|}
\hline \multicolumn{1}{|c|}{ PCNs } & \multicolumn{1}{c|}{ The Ontario Curriculum } \\
\hline Criado em 1998 & Criado em 2005 \\
\hline Não é obrigatório & É obrigatório \\
\hline Divide a Matemática em quatro eixos & Divide a Matemática em cinco eixos \\
\hline $\begin{array}{l}\text { Construções geométricas citadas: } \\
\begin{array}{l}\text { Retas paralelas, retas perpendiculares, } \\
\text { mediatriz, bissetriz, altura, mediana e e } \\
\text { divisão de segmentos e partes iguais. }\end{array}\end{array}$ & $\begin{array}{l}\text { Construções geométricas citadas: } \\
\text { Retas paralelas, retas perpendiculares, } \\
\text { ângulos, figuras planas, triângulos, } \\
\text { quadriláteros, bissetriz e circunferência. }\end{array}$ \\
\hline
\end{tabular}

Quadro 1 - Comparativo entre currículo brasileiro e canadense 


\begin{tabular}{|l|l|}
\hline \multicolumn{1}{|c|}{ Guia do Livro Didático } & \multicolumn{1}{c|}{ The Trillium List } \\
\hline Nova publicação a cada três anos & Atualização anual \\
\hline Onze obras aprovadas & Três obras aprovadas \\
\hline Âmbito nacional & Âmbito regional \\
\hline $\begin{array}{l}\text { As obras são sujeitas a doze critérios } \\
\text { eliminatórios referentes à matemática } \\
\text { além dos critérios comuns a todas as } \\
\text { áreas. }\end{array}$ & $\begin{array}{l}\text { As obras são sujeitas a catorze critérios } \\
\text { eliminatórios ao todo. }\end{array}$ \\
\hline
\end{tabular}

Quadro 2 - Comparativo entre documentos oficiais brasileiros e canadenses 


\section{A CONSTRUÇÃO GEOMÉTRICA NOS LIVROS DIDÁtICOS DE MATEMÁTICA SELECIONADOS}

As quatro coleções escolhidas para análise do conteúdo de construção geométrica são: Projeto Teláris, da editora Ática, Matemática na medida certa: nos dias de hoje, da editora Leya, Nelson Mathematics, da editora Nelson e Math Makes Sense, da editora Pearson. As análises de cada coleção serão realizadas de forma separada para, assim, no final do capítulo, comparar tais coleções.

Outras características dos livros também serão levadas em consideração, como o material utilizado, dimensões, paratexto e qualquer aspecto considerado importante no aprendizado do aluno e na orientação dos professores. Para isso, temos que considerar alguns pontos, como a definição e utilização de paratexto, que, segundo Genette (2009):

A obra literária consiste, exaustiva ou essencialmente, num texto, isto é (definição mínima), numa sequência mais ou menos longa de enunciados verbais mais ou menos cheios de significação. Contudo, esse texto raramente se apresenta em estado nu, sem o reforço e o acompanhamento de certo número de produções, verbais ou não, como um nome de autor, um título, um prefácio, ilustrações, que nunca sabemos se devemos ou não considerar parte dele, mas que em todo o caso o cercam e o prolongam, exatamente para apresentá-lo, no sentido habitual do verbo, mas também em seu sentido mais forte: para torná-lo presente, para garantir sua presença no mundo, sua "recepção" e seu consumo, sob a forma, pelo menos hoje, de um livro. Esse acompanhamento, de extensão e conduta variáveis, constituiu o que em outro lugar batizei de paratexto da obra [...] assim, para nós o paratexto é aquilo por meio de que um texto se torna livro e se propõe como tal a seus leitores, e de maneira mais geral ao público. (GENETTE, 2009, p. 9).

Capas, páginas iniciais, sumário, figuras, glossário, notas de rodapé, informações sobre o autor, dedicatória, subtítulo, ilustrações e materiais complementares são paratextos comuns em livros didáticos e, juntamente com o texto matemático, fazem o conjunto da obra, consumando em um livro completo e de fácil acesso.

Dassie (2011), em seu artigo intitulado "Paratextos editorias e História da Educação Matemática: uma leitura de livros didáticos", analisa uma série de livros de matemática (todas com datas de publicação inferiores a 1960) com o objetivo de 
observar os paratextos contidos nas obras e sua relevância como um todo. Segundo o autor, no livro didático é possível encontrar diversos paratextos.

A partir de uma rápida observação em diversos livros didáticos destinados ao ensino da Matemática na escola brasileira é possível perceber a presença de diversos paratextos: nome do autor seguido de dados biográficos sobre formação e atuação; títulos e subtítulos da obra; título da coleção; indicações sobre adoção; informações sobre legislação vigente; dados sobre a edição; ilustrações específicas; preço de venda; pareceres; notas do editor ou do autor; prefácios; cartas destinadas ao autor; lista de obras do mesmo autor; notas de rodapé; e anexos. Estes elementos encontram-se na capa, nas páginas iniciais, ao longo do texto e no final do livro e são produtos do autor e do editor, as pessoas responsáveis pelos paratextos. (DASSIE, 2011, p. 2)

A primeira obra analisada será Projeto Teláris, seguida do Matemática na medida certa, Nelson Mathematics e, por último, Math Makes Sense.

\title{
6.1 Projeto Teláris
}

A primeira obra é de autoria do professor Luiz Roberto Dante, livre-docente da Universidade do Estado de São Paulo, doutor em Psicologia da Educação. O fato da obra ser autoral individual foi de suma importância na sua escolha, principalmente tratando-se de um autor com várias publicações de livros didáticos de matemática do Brasil. O fácil acesso ao material (disponível em diversas livrarias físicas e digitais) também foi fundamental.

O guia do livro didático 2018 enfatiza as escolhas de atividades e a metodologia escolhida:

\begin{abstract}
A obra apresenta uma série de atividades nas quais se destacam a contextualização da Matemática em práticas sociais e a articulação interna entre os seus diversos campos. Há diferentes estratégias propostas no desenvolvimento das atividades, da validação empírica dos resultados às comprovações dedutivas formais.

$\mathrm{Na}$ metodologia adotada, os conteúdos matemáticos trabalhados contribuem para o desenvolvimento de competências cognitivas, como observar regularidades, explorar e justificar. (BRASIL, 2017, p. 85)
\end{abstract}

Toda a coleção possui características físicas semelhantes, como encadernação brochura, largura e altura (20,2 e 27,2 cm, respectivamente) e comprimento (ou profundidade) média de $2 \mathrm{~cm}$. O total de páginas varia muito de acordo com o ano, indo de 330 até 400 páginas. O material é de alta qualidade, com folhas adequadas para impressão de imagens coloridas e nítidas. Nas capas é possível observar cores vibrantes e imagens chamativas (guitarra, bicicleta, entre 
outros), parecendo terem sido inseridas com forte apelo comercial. As fontes são claras e, juntamente com o título, temos o nome do autor e o ano escolar correspondente, como é possível observar na figura.

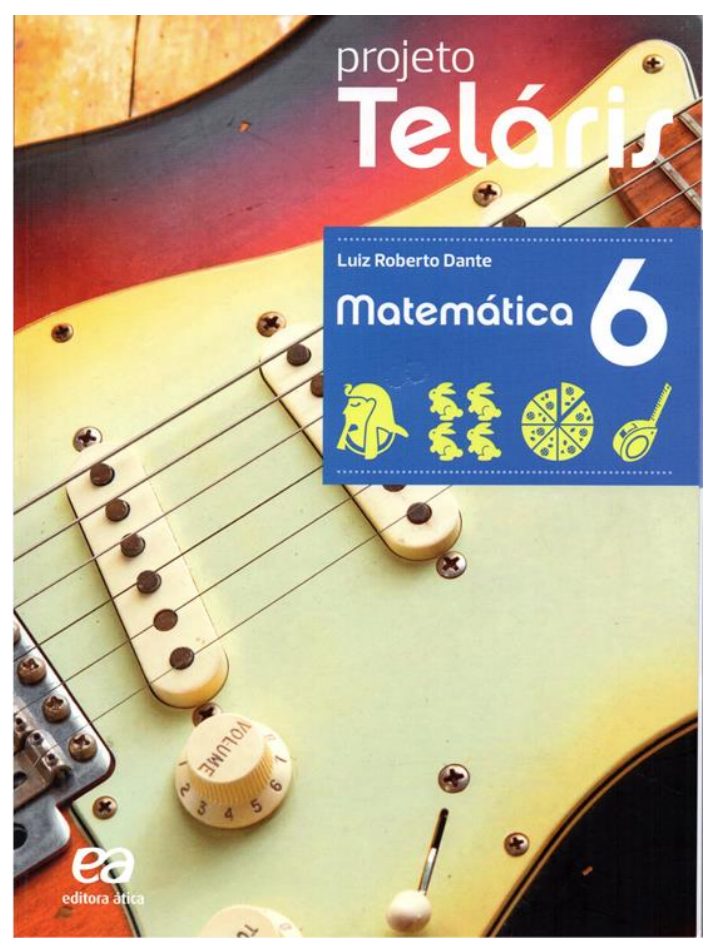

Figura 1 - Capa Projeto Teláris - Matemática 6

Na primeira página temos um encarte intitulado "estudar matemática", no qual são apresentados alguns conteúdos de modo contextualizado e, na sequência, sugestões de como estudar em casa (as sugestões variam de acordo com o livro). Uma breve apresentação do autor e uma carta endereçada aos alunos são paratextos que servem para o leitor conhecer o livro e para o autor dialogar com seus leitores, especialmente os alunos.

Ainda nos paratextos, temos a seção "Conheça seu livro de matemática", na qual é possível se familiarizar com as demais seções do livro, compreendendo o objetivo de cada uma. O sumário apresentado é bem didático, com cores distintas demarcando trocas de unidade, capítulo ou seção.

Ao longo dos capítulos encontramos alguns trechos interessantes, como o "conexões", no qual o aluno é apresentado a alguma atividade contextualizada do conteúdo, porém com uma pequena profundidade, muitas vezes adequada a trabalhos ou atividades em grupo. Ao término de cada capítulo existe uma lista extra 
de atividades intituladas "revisão cumulativa", com intuito de relembrar o aluno de todo o conteúdo apresentado no capítulo.

É visível a preocupação com o design de cada página, utilizando cores e tamanhos de letras diferentes para cada trecho, enfatizando a quebra de seção. Balões com observações são encontrados em quase todas as páginas, salientando o conteúdo localizado no texto. Imagens coloridas e nítidas ajudam a encontrar a informação desejada, passando a sensação de uma revisão contínua, no próprio capítulo, como vemos na figura 2.

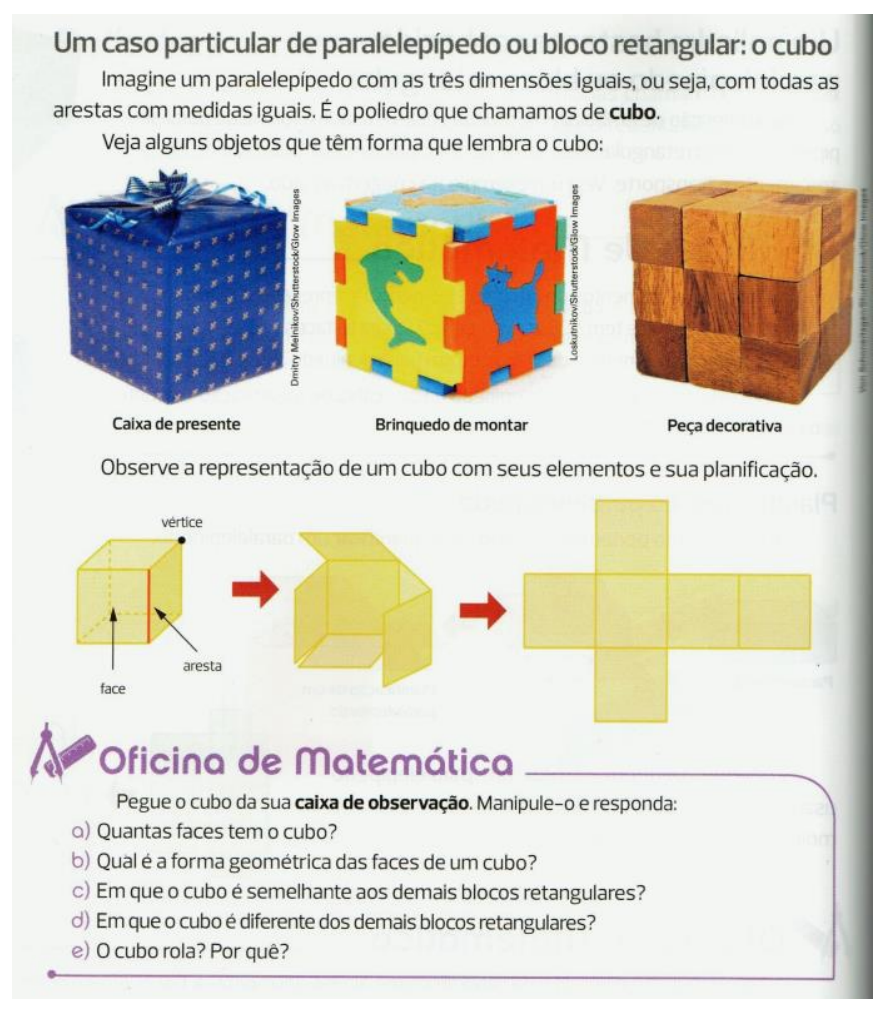

Figura 2 - Projeto Teláris - Matemática 6 - p. 78

A combinação de exercícios, problemas, desafios e oficinas auxiliam na diversidade de situações encontradas, revelando a abrangência dos conteúdos matemáticos.

No final de cada unidade é apresentada a seção "ponto de chegada" que, segundo o autor, é um encerramento de todo um trabalho, composto de três momentos: 
Seção de encerramento de cada Unidade, composta de três momentos especiais: A matemática nos textos, que apresenta leituras interessantes, geralmente relacionadas à história da Matemática; Verifique o que estudou, revisão de alguns dos temas abordados ao longo da Unidade, por meio de exercícios; Autoavaliação, momento para você refletir sobre o processo de aprendizagem e sobre atitudes que tomou em relação a seus estudos, ao professor e aos colegas. (DANTE, 2015, p. 5)

No final de cada livro encontram-se as seções "Glossário", outro paratexto, com algumas definições e representações gráficas dos objetos; "Respostas", contendo respostas dos exercícios (com exceção de alguns dissertativos); "Leituras complementares e sugestões de sites", que como o próprio nome diz traz alguns livros, revistas e sites interessantes para os alunos; "Bibliografia" e "Material complementar", com algumas figuras espaciais planificadas, malhas quadriculadas, tangram e peças para jogos mencionados ao longo da obra.

\subsubsection{Projeto Teláris 6}

O primeiro livro da coleção é o que possui um menor número de páginas dedicadas à geometria, com apenas dois capítulos e um total de 70 páginas (em um total de 360 páginas) sobre o assunto. O terceiro capítulo da primeira unidade é específico de geometria, "Geometria: sólidos geométricos, ângulos e polígonos". Nele, os alunos tem a oportunidade de aperfeiçoar alguns conteúdos já aprendidos anteriormente.

Durante a primeira e segunda seções do capítulo (Introdução e Sólidos geométricos, respectivamente), os alunos não estão em contato direto com a construção geométrica, apenas algumas representações de objetos sólidos e planificados são apresentadas na seção "material complementar".

Nas duas seções seguintes (Ponto, plano, reta e ângulos, respectivamente) a ideia de construção geométrica é mais visível, porém não da forma esperada, já que se perde a oportunidade de apresentar o conteúdo utilizando régua e compasso. O primeiro exemplo apresentado é de um campo de futebol, na sequência é formalizado com as representações matemáticas. Nesse intervalo seria possível mostrar a criação das retas, semirretas e segmentos de reta, por mais simples que sejam. O mesmo ocorre com os ângulos. 


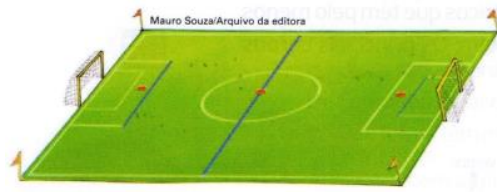

3 Ponto, plano e reta

Examine o desenho de um campo de futebol com as linhas demarcatórias.

Por meio deste desenho ou de partes dele, podemos ter ideia de várias figuras geométricas que estudaremos neste capitulo.

- O que aparece em vermelho, como o centro do campo, por exemplo, nos dá ideia de ponto.

Veja ao lado como representamos os pontos.

Cada um é indicado por uma letra maiúscula.

- Imagine o gramado (ou piso) do campo se expandindo indefinidamente em todas as direções e você terá ideia do que seja um plano. Costumamos indicar cada plano por uma letra grega: $\alpha$ (alfa), $\beta$ (beta), $\gamma$ (gama), etc.

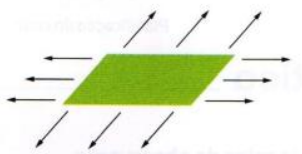

- Observe, na figura do campo de futebol, as partes destacadas em azul. Cada uma delas dá ideia de mais uma figura geométrica: o segmento de reta.

Veja o desenho e a representação de um segmento de reta:

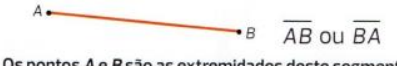

- Pense agora em um segmento de reta $A B$ que se prolonga indefinidamente nos dois sentidos. A figura correspondente é uma reta

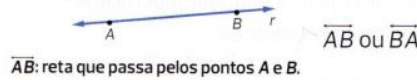

Figura 3 - Projeto Teláris - Matemática 6 - p. 82

No término da seção de ângulos, uma oficina de Matemática chamou a atenção. Mesmo não sendo uma atividade de construção geométrica, seu objetivo é construir um ângulo de 90 utilizando apenas uma folha sulfite e um lápis. Com isso, a concepção de construir algo em uma folha através de algumas etapas é introduzida aos alunos.

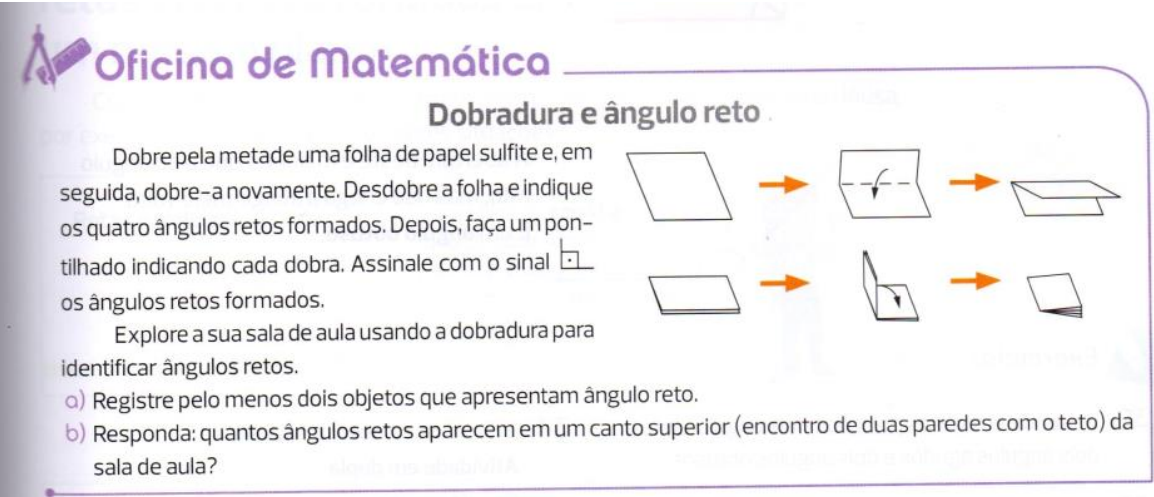

Figura 4 - Projeto Teláris - Matemática 6 - p. 87 
A sexta seção do capítulo (Construções com régua e esquadro), como o próprio nome indica, orienta o aluno a construir retas perpendiculares e paralelas, conteúdo observado na seção anterior (Retas paralelas e retas concorrentes), porém utilizando apenas régua e esquadro. Para instruir as etapas de construção, o autor utiliza fotografias e imagens desenhadas, ampliando a diversidade de exemplos. As etapas são bem didáticas, porém o compromisso do professor é fundamental, já que, por tratar-se de um livro físico e não de um software de geometria dinâmica, o espaço deixado entre uma imagem e outra pode confundir o aluno.

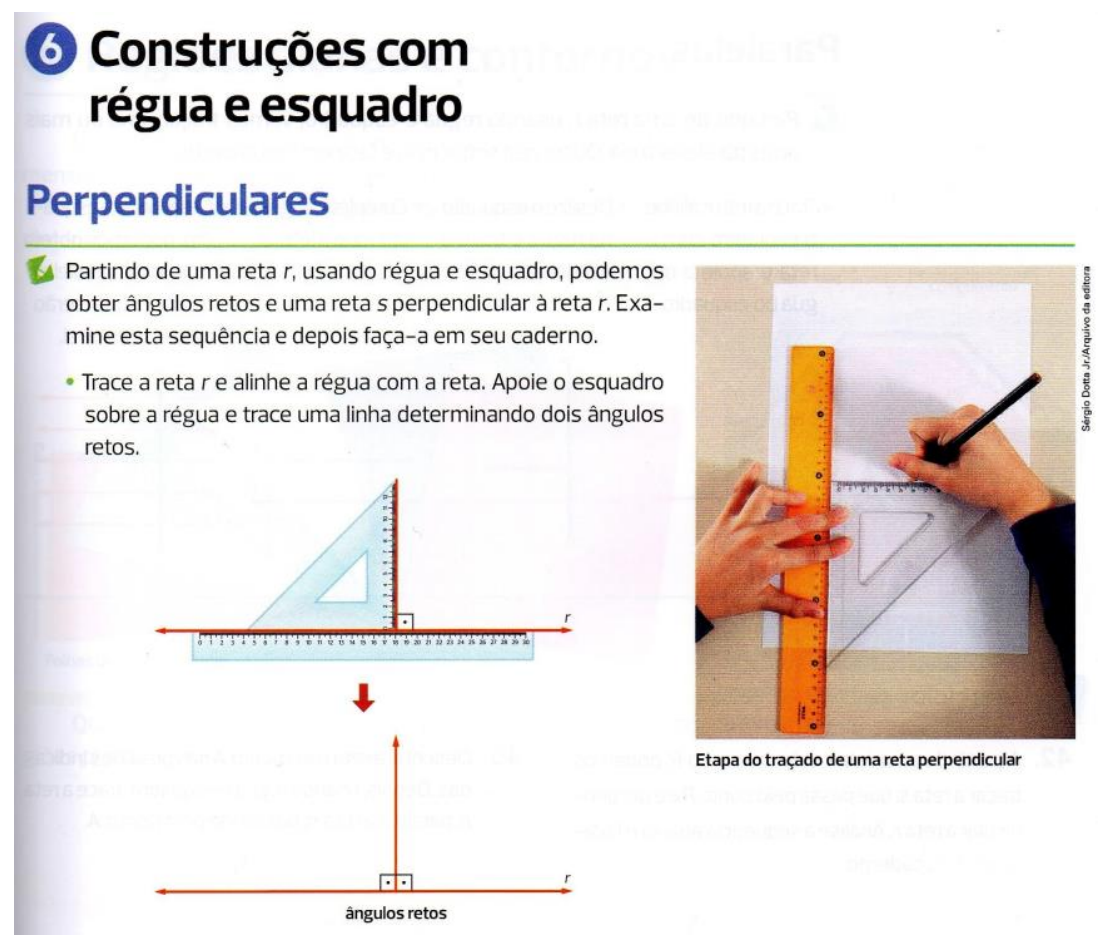

Figura 5 - Projeto Teláris - Matemática 6 - p. 91 


\section{Paralelas}

Partindo de uma reta $r$, usando régua e esquadro, vamos traçar uma ou mais retas paralelas a ela. Observe a sequência e faça em seu caderno.

- Tracearetar,alinhe - Deslize o esquadro • Completea figurae • Deslizando oesquao esquadro com a na régua e trace a coloque a letras. dro, podemos obter reta e apoie a ré- paralela à retar. mais retas paralelas gua no esquadro. à reta $r$, que serão

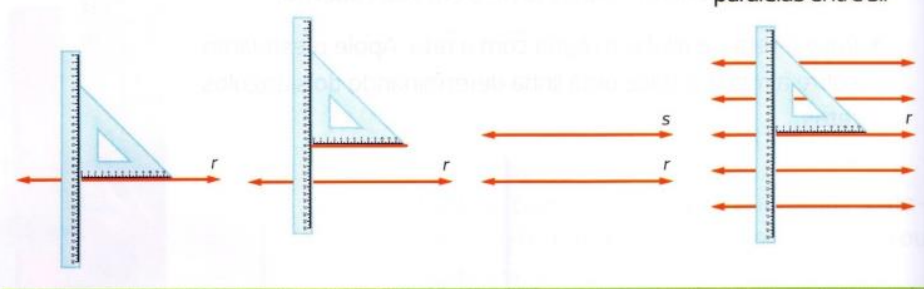

Figura 6 - Projeto Teláris - Matemática 6 - p. 92

Não fica evidente a escolha por esse procedimento, já que também é possível construir tais retas utilizando régua e compasso, como é a prática na construção geométrica. Nos próximos livros da coleção analisaremos se o autor retoma o conteúdo com a abordagem tradicional. Nesse momento convém apresentar um exemplo de construção geométrica de retas paralelas, segundo Bianchini (2006) em seu livro "Matemática $8^{\circ}$ ano":

Construindo retas paralelas com régua e compasso

Vamos construir, com auxílio de uma régua e de um compasso, uma reta paralela a uma reta $r$ dada e que passe por um ponto $P$, também dado.

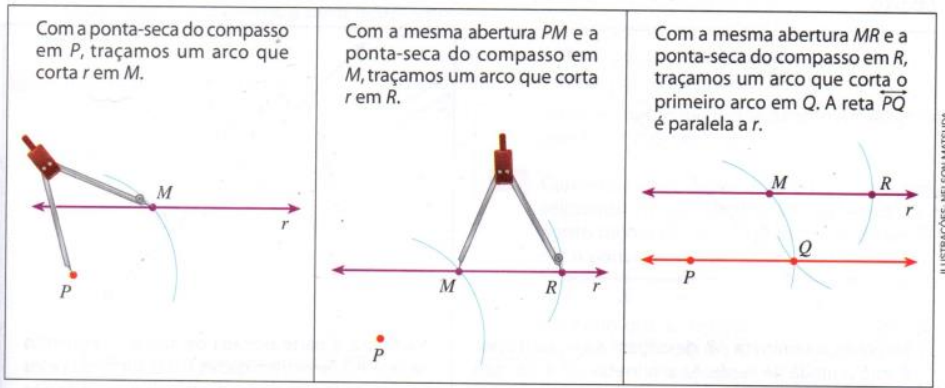

Nessa construção, $\overline{P M}, \overline{M R}, \overline{R Q}$ e $\overline{Q P}$ têm mesma medida, que é a da abertura $P M$ do compasso. Então, a figura $P M R Q$ é um losango.

Como os lados opostos de um losango são paralelos, então $\overleftrightarrow{P Q} / / \overrightarrow{M R}$.

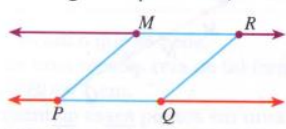

Figura 7 - Matemático 8o ano - p. 13

Fonte: Bianchini, 2006, p.13 
Tais procedimentos (ou similares) não são salientados em todo o livro do $6^{\circ}$ ano da coleção Projeto Teláris, livro no qual são apresentados os conteúdos matemáticos de retas paralelas e perpendiculares.
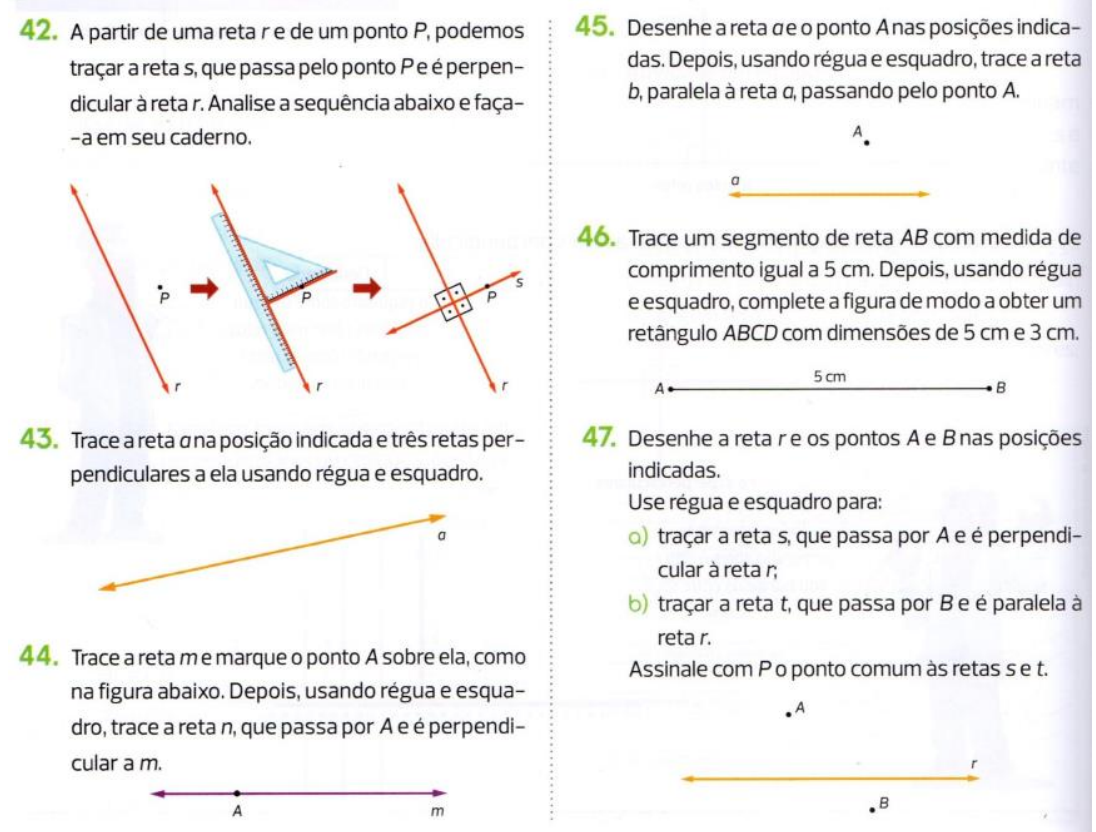

Figura 8 - Projeto Teláris - Matemática 6 - p. 92

Os exercícios da figura 8 seguem fielmente as explicações da seção, muitas vezes repetindo os próprios exemplos, mas na forma de exercício. O único item discrepante é o exercício 46, no qual o objetivo final não é traçar as retas, mas sim construir um quadrilátero com as medidas dadas. Esse tipo de exercício evidencia a importância do conteúdo, pois o mesmo não é visto como "produto final", mas sim como uma ferramenta para solucionar outro desafio. Nos demais, a construção das retas é suficiente para solucionar o problema.

Por outro lado, o modelo apresentado no livro, e consequentemente no exercício, não possui a mesma precisão da construção com régua e compasso, e tal fato deve ser salientado.

Os polígonos são introduzidos com mais formalidade na seção Regiões Planas e Contornos. Nessa seção, são apresentados os elementos de um polígono, definição, exemplos e nomeação em relação aos lados. Nos exercícios observa-se a preocupação com o reconhecimento dos polígonos no cotidiano e a identificação de seus elementos e nomes, não se atentando à construção, mesmo que elementar. 

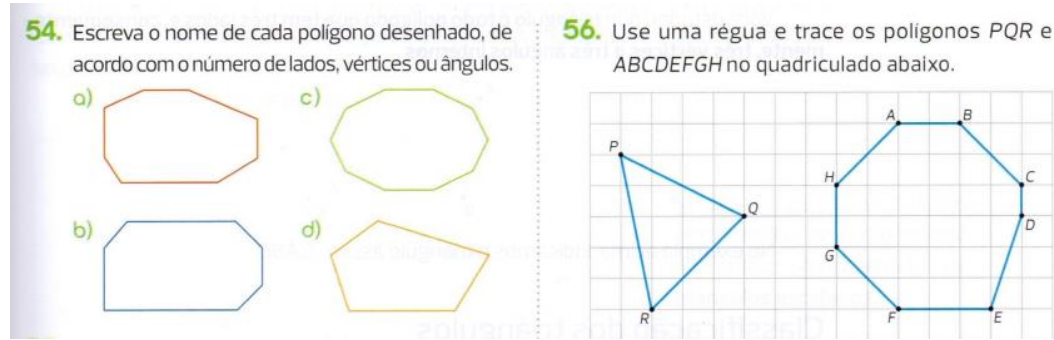

Figura 9 - Projeto Teláris - Matemática 6 - p. 101

Na mesma seção encontra-se uma oficina de matemática com o objetivo de produzir alguns polígonos utilizando canudos e barbante. A intenção de tornar o conteúdo mais tangível é interessante, já que o próprio aluno constrói os polígonos de seu modo, sem preocupações com tamanhos ou regularidades. Esse momento seria propício para introduzir alguma construção com régua e compasso, ou como fato histórico, realizar uma conexão com o modo como tais polígonos eram construídos na Antiguidade.

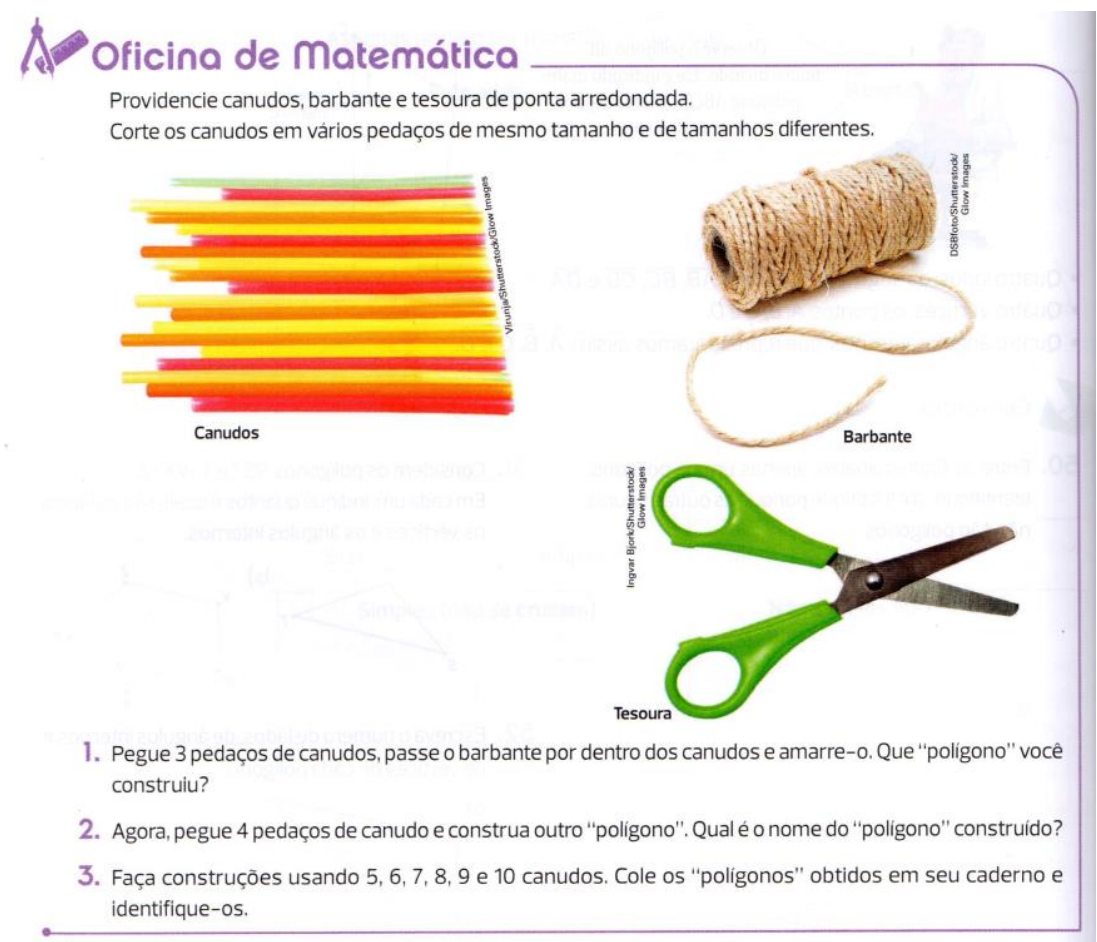

Figura 10 - Projeto Teláris - Matemática 6 - p. 100

Apenas dois tipos de polígonos, triângulos e quadriláteros são estudados de forma separada no capítulo. Novamente a construção geométrica não é utilizada no desenvolvimento do conteúdo, é abordado apenas seus respectivos tipos e 
classificações. É visível, na lista de exercícios, a preocupação com identificação e nomeação das figuras no lugar de construção e entendimento histórico.

\section{Triângulos}

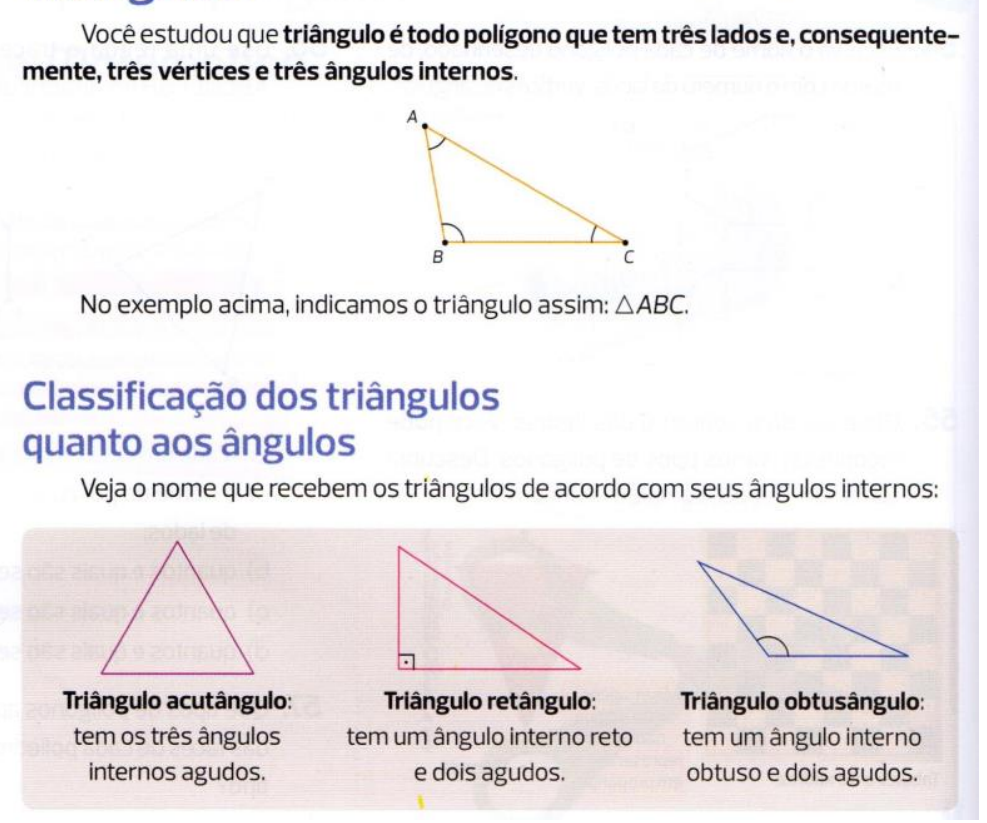

Figura 11 - Projeto Teláris - Matemática 6 - pg. 102

59. Desenhe um $\triangle D E F$ e indique quais são seus lados, seus vértices e seus ângulos internos.

60. Analise os ângulos internos de cada triângulo abaixo e classifique-o quanto a esses ângulos.
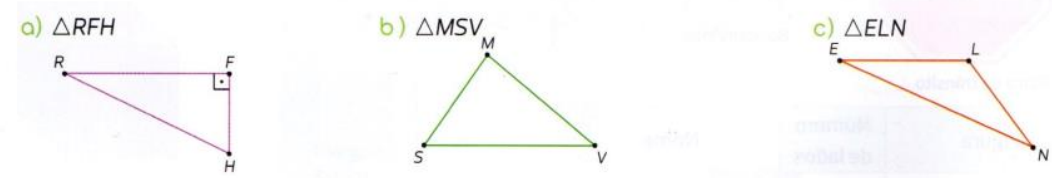

61. Use os quadriculados e trace o $\triangle A B C, 0 \triangle P Q R$ e o $\triangle M N O$. Em seguida, escreva o nome de cada triângulo de acordo com seus ângulos internos.
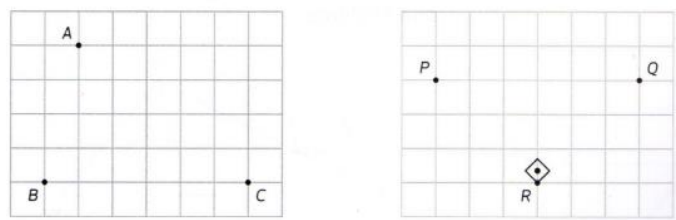

Figura 12 - Projeto Teláris - Matemática 6 - p. 102

Os exercícios 59 e 61 (figura 12) tangenciam a construção geométrica, mas trata-se apenas de desenhos livres ou utilização simples de folha quadriculada. A escolha pelo quadriculado é útil, pois auxilia o aluno a observar se um ângulo é ou não de $90^{\circ}$ com maior facilidade, o que elimina a necessidade da utilização do símbolo de ângulo reto. 
Ainda no capítulo, encontramos as seções "Outros contextos", "Praticando um pouco mais" e "Revisão cumulativa", porém em nenhum dos exercícios é encontrado algo sobre construção geométrica, o que é esperado, pois condiz com o conteúdo do capítulo.

Ao término do capítulo temos a seção "Ponto de chegada", trazendo dois textos sobre matemática. O primeiro diz respeito à origem da palavra "matemática", enquanto o segundo explica a origem da palavra "geometria". Um ponto interessante é a imagem utilizada, obra de Rafael Sanzio ${ }^{31}$, mostrando uma idealização da aparência de Euclides que foi retratado utilizando um compasso, cercado de pessoas. Alguns exercícios são propostos para discutir o texto e as imagens contidas na seção, incluindo um debate sobre a obra de Rafael Sanzio e o significado atual da geometria.

O historiador Heródoto (século $V$ a.C.) atribuiu ao povo egípcio a origem da Geometria. Alguns agricultores egípcios possuíam terras próximas ao rio Nilo, o segundo maior rio do mundo, com $6741 \mathrm{~km}$ de extensão> Para delimitar essas terras, eram utilizadas cercas.

Quando o Nilo transbordava, a água derrubava as cercas e os marcos desapareciam. Por isso, os encarregados do faraó tinham de medir novamente os terrenos. Daí a denominação grega Geometria (geo significa "terra"; metria significa "medida"), cujo significado é medida da terra. Atualmente, pode-se dizer que Geometria é o estudo das figuras geométricas, incluindo o cálculo de medidas ligadas a elas.

Muitos povos antigos usaram e estudaram Geometria, mas quem primeiro organizou e sistematizou logicamente esses conhecimentos foi o grego Euclides (século III a.C.) em sua obra Os elementos. Em sua homenagem, a Geometria que estudamos hoje no Ensino Fundamental e no Médio é chamada euclidiana. (DANTE, 2015, p.112)

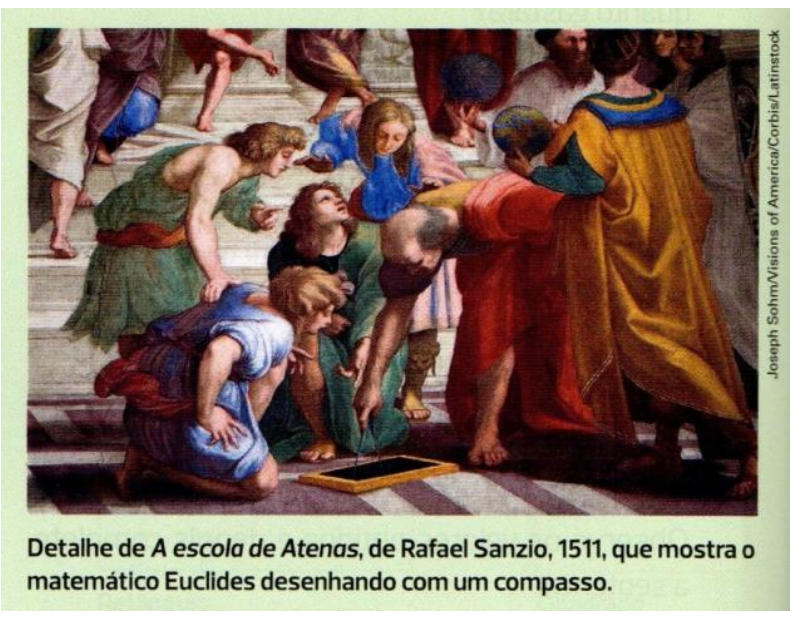

Figura 13 - Projeto Teláris - Matemática 6 - p. 112

\footnotetext{
${ }^{31}$ Rafael Sanzio, pintor e arquiteto italiano.
} 
Outro capítulo que aborda o tema geometria, mesmo que não unicamente, é o capítulo 8 da $4^{\mathrm{a}}$ unidade, intitulado "Grandeza comprimento e grandeza superfície". Nele, o conteúdo de polígonos é revisado brevemente para, então, introduzir os conceitos de perímetro e área. A ideia de construção geométrica é inexistente nesse capítulo, dando vez às fórmulas matemáticas. Diferentemente do capítulo anterior, a seção "Ponto de chegada" não traz nenhum questionamento relevante para nossa pesquisa.

Na nossa opinião, o livro do 6º ano da coleção Projeto Teláris não aborda de forma significativa a construção geométrica, ou seja, de forma que inclua conteúdos que, em sua natureza, trazem esse conhecimento. Notamos apenas que, em alguns aspectos, o autor relaciona a ideia de construção geométrica com alguns exercícios e oficinas.

\subsubsection{Projeto Teláris 7}

Semelhante ao anterior, o livro do sétimo ano da coleção Projeto Teláris traz dois capítulos focados em conteúdos geométricos (no total de 9 capítulos). No primeiro deles, o enfoque é em sólidos geométricos, suas planificações, polígonos e simetria. Já é esperado a falta de construção geométrica nos conteúdos envolvendo sólidos geométricos, mas o autor utiliza a palavra "construção" em alguns casos, principalmente em atividades com poliedros.

Ao término do capítulo temos um jogo matemático no qual o aluno constrói o "esqueleto" de um poliedro, utilizando palitos e massa de modelar. Sabemos que a atividade não utiliza conhecimentos de construção geométrica, mas, de forma semelhante, coloca o aluno no papel de criador, gerando a figura desejada e utilizando poucas ferramentas. Vale salientar que o jogo apresentado não utiliza as formalizações e precisão da construção geométrica, sendo assim, os objetos construídos serão apenas aproximações.

Polígonos são revisitados, porém ainda sem envolver as suas criações de fato. Algo semelhante ocorre com a simetria, que é abordada, mas sem traços de utilização de construção geométrica. 
O segundo, e último, capítulo que aborda o tema geometria, é focado em ângulos e polígonos (especialmente os ângulos internos dos polígonos). Ao tratar o assunto de ângulos, as posições relativas de duas retas são mencionadas, porém sem aprofundamento, como vemos na figura 14 .

\section{Posições relativas de duas retas em um plano}

Você se lembra?

Duas retas distintas de um mesmo plano podem ser retas paralelas retas concorrentes perpendiculares ou retas concorrentes obliquas.

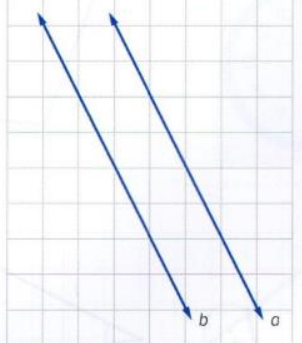

$a$ e $b$ são retas paralelas $(a / / b)$.

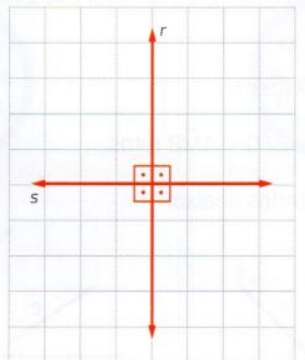

re ssão retas concorrentes perpendiculares $(r \perp s)$.

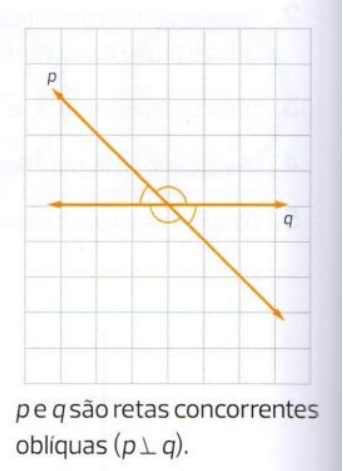

pe qsão retas concorrentes obliquas $(p \perp q)$

Figura 14 - Projeto Teláris - Matemática 7 - p. 184

Na seção sobre ângulos, o autor trabalha com construções de ângulos, mas apenas com a utilização de transferidor, não envolvendo régua e compasso. Algumas figuras são encontradas no livro para facilitar o entendimento dos alunos. Foi encontrado apenas um exercício solicitando a construção de ângulos.

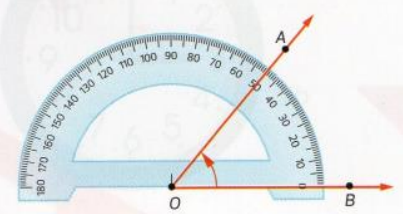

$\mathrm{m}(A \hat{O} B)=50^{\circ}$

AÔB é um ângulo agudo, pois mede entre $0^{\circ}$ e $90^{\circ}$.

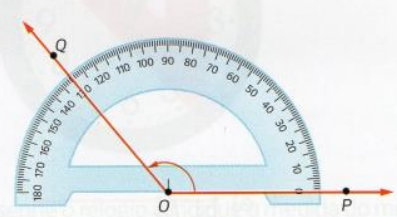

$\mathrm{m}(Q \hat{P} \mathrm{P})=130^{\circ}$

QÔP é um ângulo obtuso, pois mede entre $90^{\circ}$ e $180^{\circ}$.

Figura 15 - Projeto Teláris - Matemática 7 - p. 188 
19. Construa os ângulos indicados. Use um transferidor.
a) $E \hat{A} C$ de $40^{\circ}$
c) $P \hat{Q} R$ de $180^{\circ}$
b) $F \widehat{M} H$ de $120^{\circ}$
d) $S \hat{X} J$ de $25^{\circ}$

Figura 16 - Projeto Teláris - Matemática 7 - p. 189

Na mesma seção temos "bissetriz de um ângulo", mas, novamente, o assunto é abordado superficialmente, sem trabalhar com construções geométricas. Entretanto, um eixo de simetria é encontrado numa dobradura, como vemos na figura abaixo:

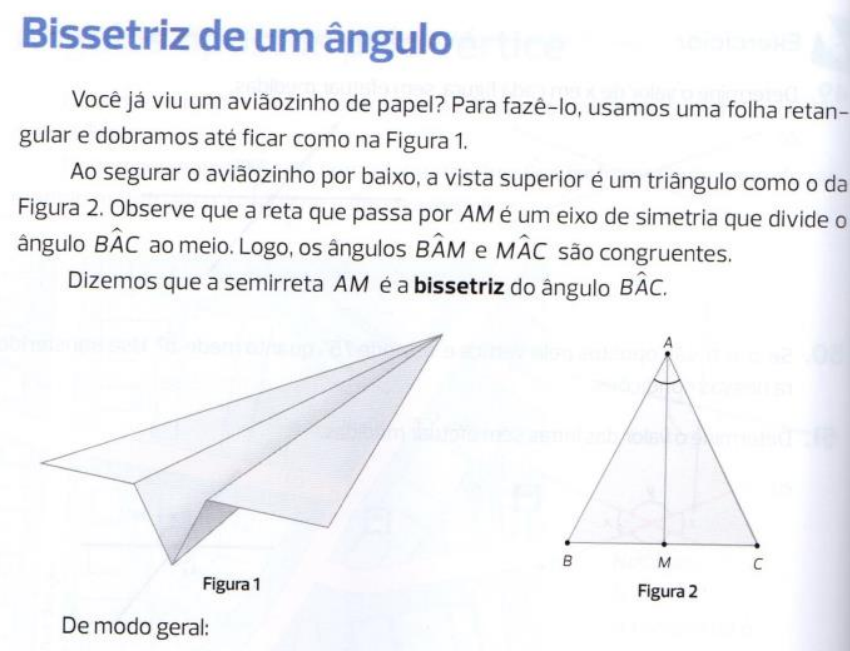

Bissetriz de um ângulo é a semirreta de origem no vértice que determina, com os lados do ângulo, dois ângulos congruentes, ou seja, de medidas iguais.

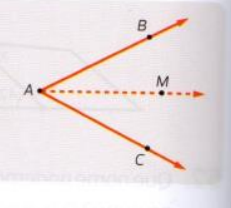

Figura 17 - Projeto Teláris - Matemática 7 - p. 198

$\mathrm{Na}$ figura acima observamos um erro de nomenclatura. O autor utiliza o termo semirreta AM, mas na figura do triângulo é possível perceber que se trata de um segmento de reta.

Em polígonos, temos um enfoque nas medidas de seus ângulos, internos e externos, e nas suas somas. Uma oportunidade de abordar construção geométrica é observada em uma oficina de matemática, mas o autor decide não utilizar, deixando a construção de triângulos a mão livre. 


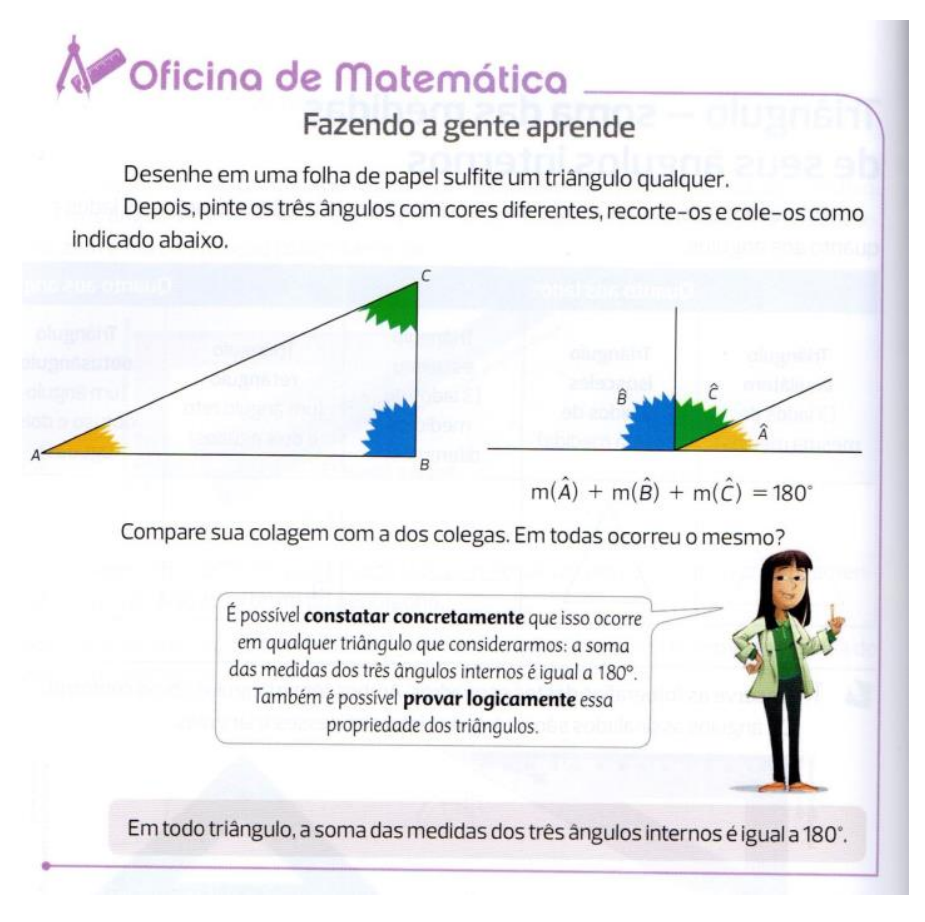

Figura 18 - Projeto Teláris - Matemática 7 - p. 202

Como trata-se de uma oficina, ainda com o subtítulo "Fazendo a gente aprende", seria uma excelente oportunidade introduzir a construção geométrica.

Na nossa opinião, o livro do $7^{\circ}$ ano da coleção Projeto Teláris revisita muito o conteúdo do livro anterior, alguns nos quais a utilização da construção geométrica seria possível, mas acaba seguindo outro caminho, deixando de inserir atividades a respeito.

\subsubsection{Projeto Teláris 8}

O terceiro livro da coleção, Projeto Teláris 8, possui quatro capítulos focados em geometria (de um total de oito), dois a mais que seus antecessores. O primeiro deles, terceiro capítulo do livro, engloba os conteúdos de ângulos, triângulos e quadriláteros.

As primeiras seções abordam conteúdos já vistos anteriormente, servindo como revisão para os alunos. Em relação a conteúdos novos, o primeiro é a soma das medidas dos ângulos internos e externos de um polígono convexo e regular. E, ainda relacionado com esse tema, o autor utiliza uma figura de um geoplano, objeto feito de madeira e pregos, que auxilia na observação de polígonos como um todo. 


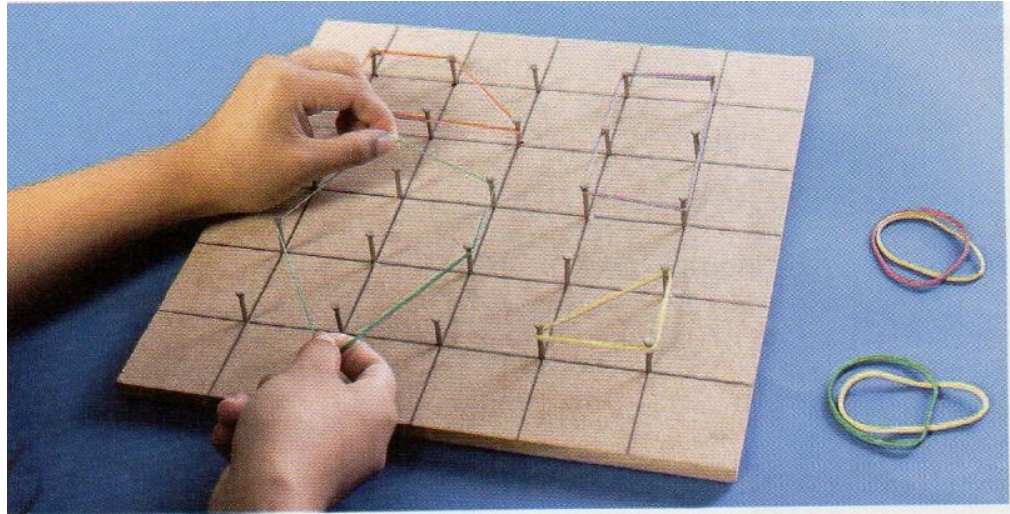

Geoplano de madeira. Com este instrumento podemos representar vários poligonos.

Figura 19 - Projeto Teláris - Matemática 8 - p. 85

O único momento que o geoplano aparece é na figura. Nenhum exercício, desafio, oficina ou jogo trabalha com esse objeto geométrico.

A sexta seção do capítulo aborda triângulos, aprofundando ainda mais seu estudo. Logo no início temos a condição de existência do triângulo e, nela, o autor opta pela construção geométrica, utilizando régua e compasso para, posteriormente, validar a desigualdade triangular. Na figura 18 vemos a abordagem escolhida pelo autor:

\section{Condição de existência de um triângulo}

Fábio construiu, com régua e compasso, um triângulo com lados de $4 \mathrm{~cm}, 3 \mathrm{~cm}$ e $2 \mathrm{~cm}$, representado a seguir.

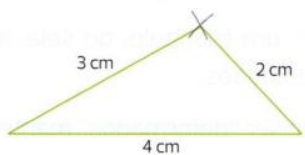

Denise tentou construir um triângulo com lados de $4 \mathrm{~cm}, 2 \mathrm{~cm}$ e $1,5 \mathrm{~cm}$, mas não conseguiu.

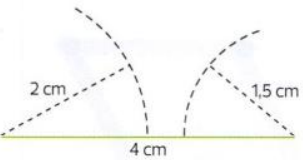

Ficou, então, a pergunta: "Em que condição, dadas as medidas de três segmentos de reta, é possivel construir um triângulo cujos lados tenham essas medidas?". Procure encontrar a resposta fazendo o exercício a seguir.

Figura 20 - Projeto Teláris - Matemática 8 - p. 96 


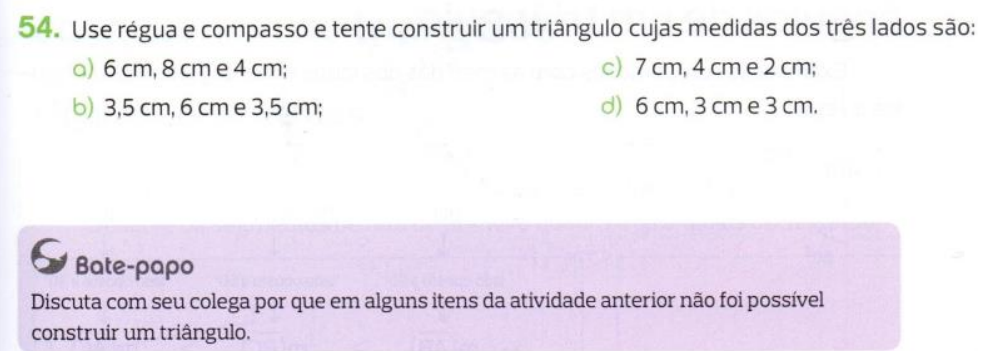

Figura 21 - Projeto Teláris - Matemática 8 - p. 97

Observamos, também, um exercício de criação de triângulos na página seguinte (como visto na figura 20). Um paratexto chamado "bate-papo" questiona os alunos, fazendo-os discutir com os colegas o porquê de alguns itens do exercício anterior não satisfazerem a construção do triângulo. Outro exercício semelhante é encontrado no final da página.

Uma oficina de Matemática é apresentada na sequência do conteúdo. Nela, os alunos trabalharão em grupos e, utilizando régua, compasso e transferidor, construirão triângulos seguindo as regras apresentadas na atividade. A atividade torna-se instigante pois, ao debater em grupo, os alunos podem observar alguns casos de congruência de triângulos, tema abordado após a atividade.

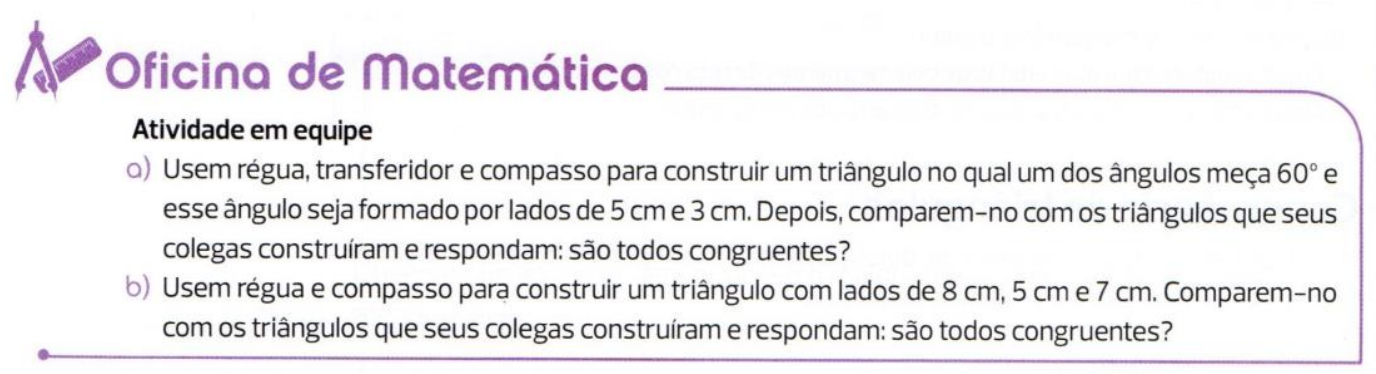

Figura 22 - Projeto Teláris - Matemática 8 - p. 100

Ao tratar mediatriz de um segmento de reta, o autor opta pela construção geométrica, mas a insere em um exercício e não no texto de apresentação do conteúdo. No exercício em questão (figura 21), o autor sugere uma atividade em grupo, e utiliza de imagens passo a passo como exemplo de construção de mediatriz. 
84. Traçado da mediatriz de um segmento de reta com uso de régua e compasso Atividade em equipe

Analisem esta sequência de figuras para traçar a mediatriz de $\overline{A B}$. Em seguida, reproduzam-na no caderno Conversem com os colegas sobre qual deve ser a abertura do compasso.
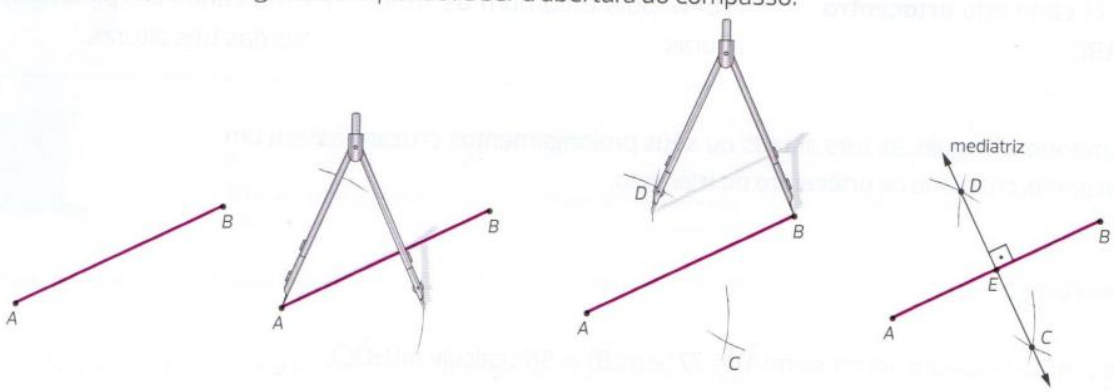

Figura 23 - Projeto Teláris - Matemática 8 - p. 110

As imagens não são suficientes para a elaboração da atividade, pois algumas informações relevantes não são encontradas nos textos do exercício.

O questionamento feito pelo autor na atividade, "Conversem com os colegas sobre qual deve ser a abertura do compasso" (DANTE, 2015, p.110), traz a idealização de que, mesmo sem um amplo conhecimento de mediatriz, da utilização de compasso e da construção geométrica como um todo, o aluno compreenderia tais informações. Para que isso ocorra, a participação do professor, como mediador, é fundamental na realização dessa atividade.

Circuncentro do triângulo é abordado utilizando os mesmos conceitos da mediatriz, logo, o aluno deverá encontrar, utilizando régua e compasso, as três mediatrizes e, na sequência, localizar o ponto de intersecção e construir a circunferência. Alguns exercícios são propostos nessa seção, incluindo uma oficina de Matemática. 


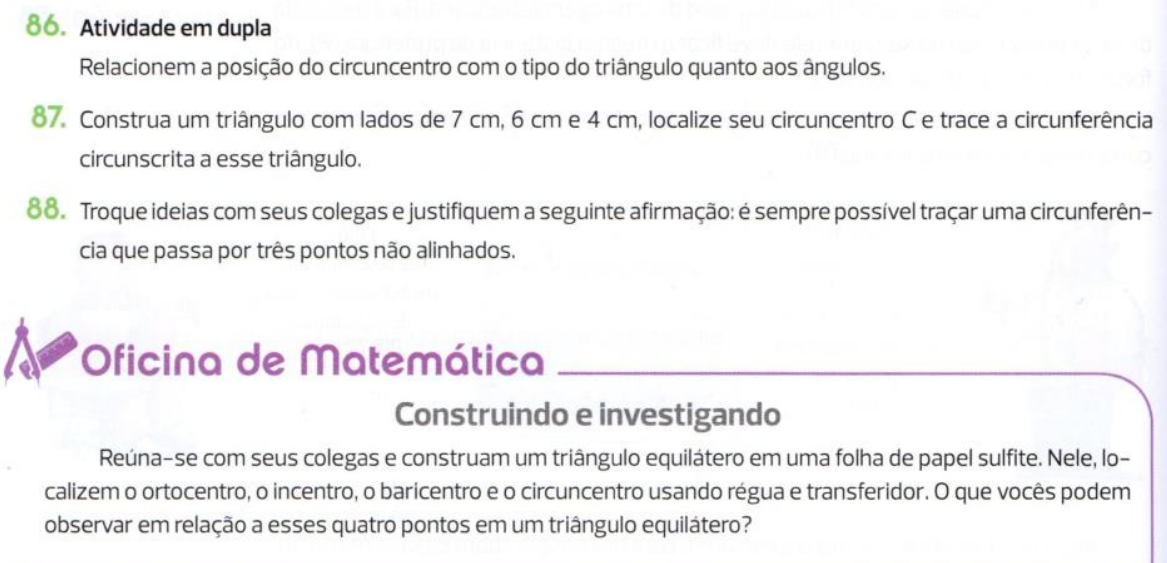

Figura 24 - Projeto Teláris - Matemática 8 - p. 112

No restante do capítulo (seção de quadriláteros) não observamos nenhuma utilização de construção geométrica, apenas um comentário sobre as diagonais do losango serem segmentos de reta contidas em retas mediatrizes entre si, como vemos na figura 25 .

Veja:

$A C B D$ é um losango e $\overline{A B}$ e $\overline{C D}$ são suas diagonais.

Logo, $\overline{A E} \cong \overline{B E}$ e $C \hat{E} B$ é reto, pois as diagonais do losango cortam-se ao meio

e são perpendiculares.

Podemos então afirmar que $\overrightarrow{C D}(m)$ é a mediatriz de $\overline{A B}$.

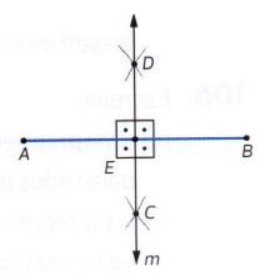

Figura 25 - Projeto Teláris - Matemática 8 - p. 117

No sexto capítulo referente à geometria, temos o enfoque em circunferências. Nele, temos a utilização de compasso para construção, como vemos em alguns exercícios ao longo do livro.

10. Usando régua, compasso e transferidor, construa:

a) uma circunferência com centro $O$ e raio de $3 \mathrm{~cm}$. Trace nela um raio $\overline{O A}$.

b) uma circunferência com centro $M$ e raio de $4 \mathrm{~cm}$. Trace nela um diâmetro $\overline{E F}$.

c) uma circunferência com raio de $2 \mathrm{~cm}$. Trace nela um ângulo central de $40^{\circ}$.

d) uma circunferência com raio de $2,5 \mathrm{~cm}$. Pinte nela um setor circular com ângulo de $110^{\circ}$

Figura 26 - Projeto Teláris - Matemática 8 - p. 225

No mesmo capítulo temos a seção "ângulos em uma circunferência", trazendo a construção de um hexágono regular inscrito na circunferência. O exemplo é utilizado em detrimento a uma aplicação do conteúdo "ângulo central", como vemos na figura 27. 


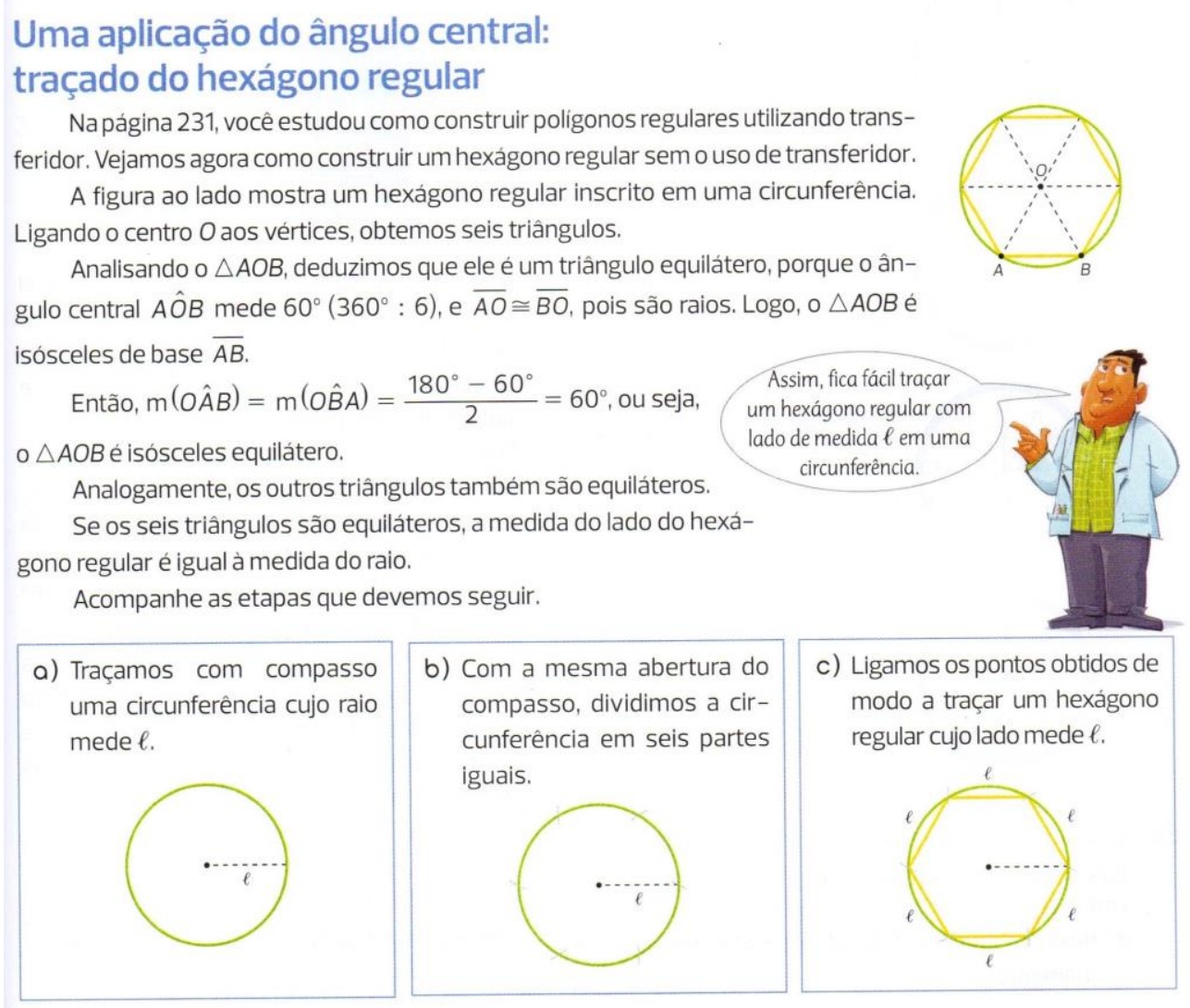

Figura 27 - Projeto Teláris - Matemática 8 - p. 239

É interessante observar a construção de um polígono regular utilizando régua e compasso, mesmo que, até o momento, seja o único caso nas obras. Três exercícios utilizam esse novo conhecimento, sendo que o primeiro (exercício 34) pede a construção de um triângulo equilátero inscrito na circunferência, e oferece uma sugestão, na qual a construção do hexágono regular (como visto no exemplo) é importante.

34. Usando régua e compasso, construa um triângulo equilátero inscrito em uma circunferência com $4 \mathrm{~cm}$ de raio. (Sugestão: faça a construção do hexágono regular e escolha os vértices adequadamente.)

Figura 28 - Projeto Teláris - Matemática 8 - p. 240

O segundo (exercício 35) é interdisciplinar, pois trabalha com contextos de artes, sendo escolhido a ideia do mosaico. O aluno deve construir seu próprio mosaico utilizando hexágonos regulares, deixando fluir sua criatividade. Com isso, o 
aluno pratica inúmeras vezes a construção do hexágono regular e treina, também, alguns conceitos da construção geométrica.

\section{Geometria e arte}

Use sua criatividade e construa um mosaico com hexágonos regulares. Pinte sua obra como quiser. Veja dois exemplos:
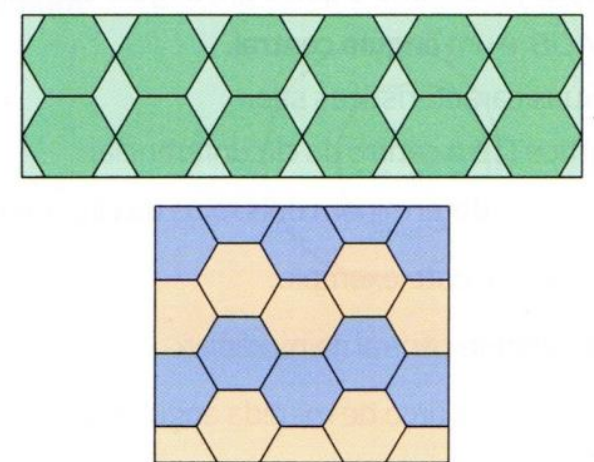

Figura 29 - Projeto Teláris - Matemática 8 - p. 240.2

O exercício 36 solicita que o aluno construa uma rosa dos ventos utilizando régua, compasso e esquadro. Mesmo não abordando diretamente a construção geométrica, o exercício em questão desvia um pouco dos tradicionais, por isso merece ser comentado. 
36. Construindo uma rosa dos ventos

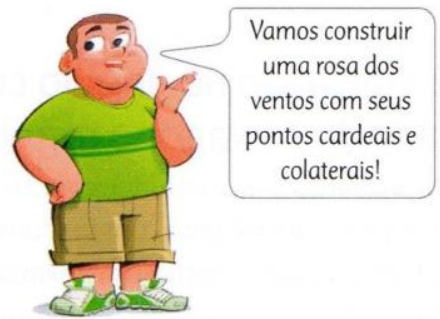

Para isso, você vai precisar de uma folha de pape sulfite, compasso, lápis de cor e esquadro.

Desenhe dois circulos com o mesmo centro (círculos concêntricos): um com $1,5 \mathrm{~cm}$ de raio e outro com $5 \mathrm{~cm}$ de raio.

Trace um segmento de reta que contenha o diâmetro do círculo menor e o do círculo maior. Com o esquadro, faça outro diâmetro que seja perpendicular ao primeiro. Desenhe agora outros dois diâmetros formando ângulos de $45^{\circ}$ com os dois primeiros que você já traçou. Marque as extremidades dos diâmetros dos dois círculos e ligue essas extremidades, obtendo assim o desenho da rosa dos ventos com os pontos cardeais e colaterais. Apague as linhas desnecessárias e pinte-o como quiser. (Este exercicio foi extraido e adaptado de: SEE-SP/CENP. Experiências matemáticas 6ª série. São Paulo, 1994.)

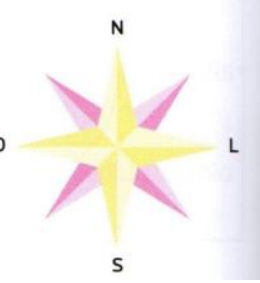

Figura 30 - Projeto Teláris - Matemática 8 - p. 240.3

O último momento que observamos a utilização de régua e compasso no capítulo é a criação de ângulos inscritos, mas apenas um exercício aborda tal conhecimento, como vemos na figura a seguir:

37. Use régua, compasso e transferidor para construir:

a) um ângulo central de $100^{\circ}$ em uma circunferência com $2 \mathrm{~cm}$ de raio;

b) um ângulo inscrito de $30^{\circ}$ em uma circunferência de $3 \mathrm{~cm}$ de raio.

Figura 31 - Projeto Teláris - Matemática 8 - p. 241

Os dois últimos capítulos do livro que abordam geometria não trabalham o conceito de construção geométrica, pois focam em perímetro, área e volume (capítulo 7) e planificações e representações de figuras geométricas sólidas (capítulo 8). Já era esperado a não utilização, dado que esses conhecimentos não 
lidam diretamente com construção geométrica, já que são temas do eixo grandezas e medidas.

$\mathrm{Na}$ nossa opinião, o livro Projeto Teláris 8 aborda mais conteúdo de construção geométrica que seus antecessores, principalmente com diversos exercícios de construção de figuras. Com a aplicação do tema circunferência, era esperado um aumento da utilização do compasso, ou seja, de exercícios que utilizassem essa ferramenta.

\subsubsection{Projeto Teláris 9}

O quarto, e último, livro da coleção é o que possui mais capítulos associados à geometria, cinco no total, um a mais que o seu antecessor, porém o primeiro capítulo com enfoque em geometria só é encontrado na unidade 2.

No início do capítulo 4 (Proporcionalidade em Geometria) são abordados alguns conteúdos já vistos, fortalecendo o ensino em espiral e adicionando alguns novos, como a proporção áurea (ou número de ouro). Na introdução do conteúdo não se utiliza de construção geométrica, mas em um exercício específico é necessário o manuseio de régua e compasso. 

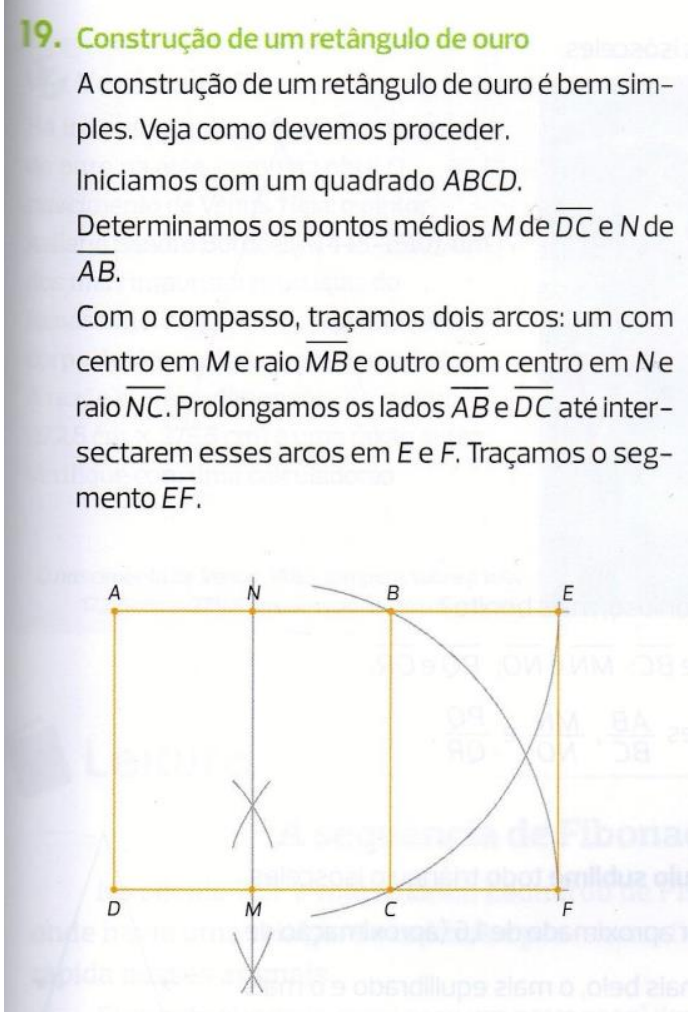

Figura 32 - Projeto Teláris - Matemática 9 - p. 149

Observa-se que o autor não informa como construir um quadrado utilizando a construção geométrica, logo, a primeira etapa da construção do retângulo de ouro já está, de certo modo, comprometida. Em nenhum dos três livros anteriores o autor aplicou a competência de construção geométrica na criação de quadriláteros, apenas a construção de retas perpendiculares, então, o aluno dependerá de um salto lógico em compreender a utilização dessa construção na elaboração de um quadrilátero.

O conhecimento utilizado na realização do exercício é a construção da mediatriz de um segmento, conteúdo abordado no livro anterior, mas não revisado no atual, além de o exercício não ter demonstrado como realizar tal etapa. Para isso, basta o conhecimento de compasso e construção de circunferências e régua com intuito de ligar alguns pontos.

Existe potencial no exercício, porém as etapas de criação foram minimizadas, tornando-o mais simples e sem a utilização real de diversos conteúdos de construção geométrica. 
$\mathrm{Na}$ página seguinte, temos o triângulo de ouro (também na forma de exercício). No entanto, nesse caso o livro não demonstra como se constrói o triângulo e, mesmo assim, é solicitado que o aluno realize a atividade (nos livros anteriores existe o conteúdo de construção de triângulos, porém pouco aprofundado).

22. Triângulo de ouro ou triângulo sublime

Os gregos chamavam de triângulo de ouro ou triângulo sublime todo triângulo isósceles como o da figura ao lado, que tem a razão $\frac{x}{a}$ com valor aproximado de 1,6 (aproximação de 1,618033989...). Segundo eles, esse triângulo era o mais belo, o mais equilibrado e o mais harmonioso aos nossos olhos.

Responda:

a) No exercício anterior, qual dos triângulos é um triângulo de ouro?

b) E você, escolheu esse triângulo como o mais bonito?

23. Use 1,6 para o número de ouro e construa um triângulo de ouro com base de $2 \mathrm{~cm}$.

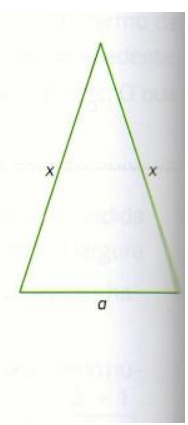

Figura 33 - Projeto Teláris - Matemática 9 - p. 150

Ainda sobre triângulos, outro exercício solicita a criação dessas figuras, mas apenas com a utilização de régua e transferidor, como visto nos livros anteriores.

28. Com régua e transferidor, construa os três triângulos retângulos indicados abaixo.
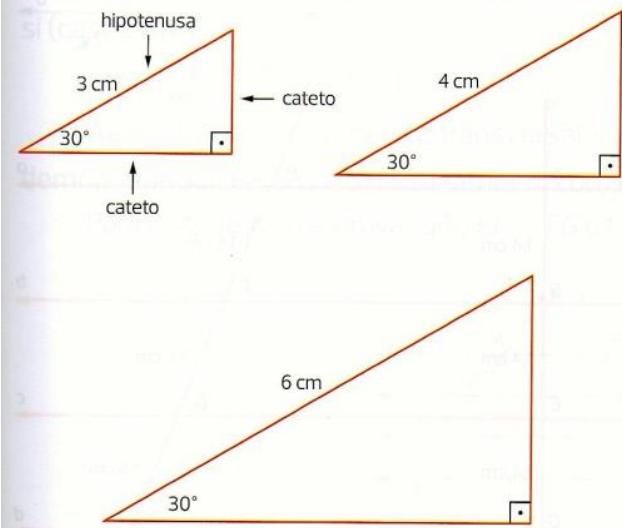

Temos aqui mais um caso de proporcionalidade na Geometria.

Faça o que se pede.

a) Quais são as medidas dos três ângulos em cada triângulo?

b) Meça o lado menor de cada triângulo.

c) Calcule em cada triângulo a razão entre a medida do lado menor (oposto ao ângulo de $30^{\circ}$ ) e a medida do lado maior (oposto ao ângulo de $90^{\circ}$ ).

Figura 34 - Projeto Teláris - Matemática 9 - p. 153 
No último conteúdo do capítulo (Teorema de Tales), é abordado o tema "divisão de um segmento de reta em partes iguais" como uma possível aplicação para o teorema de Tales. Nele, o autor utiliza régua e compasso para dividir um segmento dado em três partes iguais. Nota-se que não é necessária uma régua graduada, o que a torna uma atividade de construção geométrica.

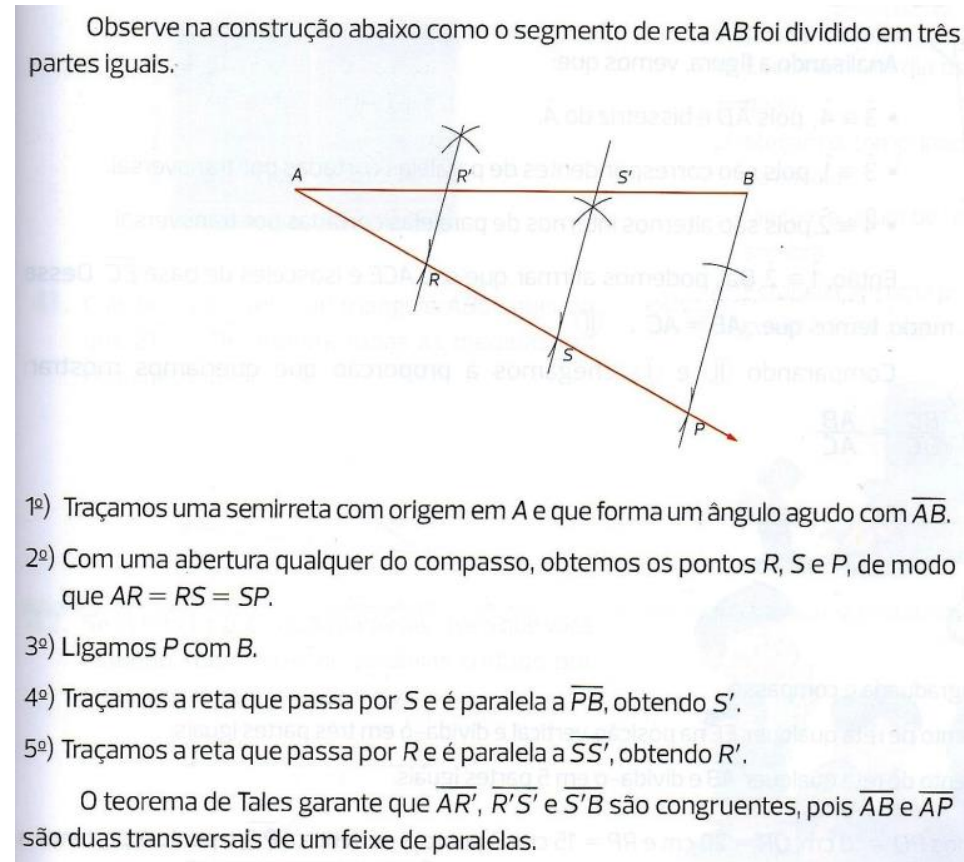

Figura 35 - Projeto Teláris - Matemática 9 - p. 159

Um exercício é apresentado na seção, no qual os alunos devem, com régua não graduada e compasso, dividir alguns segmentos em partes iguais. O interessante do exercício é a utilização do termo "régua não graduada", não usada nos demais exercícios.

37. Usando régua não graduada e compasso:

a) trace um segmento de reta qualquer EF na posição vertical e divida-o em três partes iguais;

b) trace um segmento de reta qualquer $A B$ e divida-o em 5 partes iguais.

Figura 36 - Projeto Teláris - Matemática 9 - p. 160

Nos demais capítulos sobre geometria (Semelhanças, Relações métricas no triângulo retângulo e na circunferência, Introdução à Trigonometria e Perímetros, áreas e volumes), não encontramos nenhuma utilização da construção geométrica. 
Com isso, toda a coleção foi explorada e o conteúdo de construções geométricas foi encontrado e analisado. Alguns conteúdos abordados não envolveram a construção geométrica, mesmo existindo a possibilidade para tal, como: construção de triângulos equiláteros, quadrados e polígonos regulares.

O autor aborda alguns conteúdos, mas não aprofunda, muitas vezes insere a construção geométrica em apenas um exercício, atividade ou oficina, não juntamente com o texto ou demonstração. Tal decisão remete a ideia de que a habilidade da construção geométrica se encontra apenas como supérfluo, de certo modo opcional ou apenas como curiosidade para o aluno.

\begin{tabular}{|l|l|}
\hline Conteúdo & Ferramentas \\
\hline Ângulo & Transferidor \\
\hline Ângulo reto & Régua e esquadro \\
\hline Bissetriz & Sem ferramentas \\
\hline Circuncentro & Régua e compasso \\
\hline Circunferência & Compasso \\
\hline Divisão de segmentos & Régua e compasso \\
\hline Hexágono & Régua, compasso e transferidor \\
\hline Mediatriz & Régua e compasso \\
\hline Retângulo de ouro & Régua e compasso \\
\hline Retas paralelas & Régua e esquadro \\
\hline Retas perpendiculares & Régua e esquadro \\
\hline Triângulo & Régua, compasso e transferidor \\
\hline
\end{tabular}

Quadro 3 - Conteúdos de construção geométrica Projeto Teláris 


\title{
6.2 Matemática na medida certa: nos dias de hoje
}

A segunda coleção brasileira escolhida para análise dos conteúdos de desenho geométrico foi Matemática na medida certa, dos autores Marília Centurión e José Jakubovic, da editora Leya. A escolha por tal obra deu-se pela facilidade de adquirí-la (em livrarias físicas e online), além de, juntamente com a coleção anterior, satisfazer o critério de consistência com os dados, como edição ou ano da obra entre o guia dos livros didáticos e as lojas e editoras.

O guia do livro didático de 2017 enfatiza a utilização do campo da geometria na coleção, elogiando sua conexão com os demais campos e a utilização de ferramentas na construção de ângulos.

\begin{abstract}
Observam-se conexões importantes entre conteúdos do campo [geometria] e os dos demais campos. Um bom exemplo com a álgebra são as explanações teóricas sobre produtos notáveis associados ao teorema de Pitágoras. Contextos envolvendo situações do cotidiano auxiliam a compreensão dos objetos da geometria. O estudo de ângulos é iniciado por sua identificação em diferentes contextos e por atividades de construção com o uso de instrumentos de desenho. [...] evidencia-se, também, a necessidade de não se confundirem os objetos matemáticos com as suas representações, o que é elogiável. (BRASIL, 2017, p.118)
\end{abstract}

As características físicas da coleção são semelhantes às da anterior, com $27,5 \mathrm{~cm}$ de altura, $20,5 \mathrm{~cm}$ de largura e um comprimento médio inferior a $2 \mathrm{~cm}$. $\mathrm{O}$ total de páginas varia entre 256 e 280, quantidade inferior à coleção analisada anteriormente. O livro do sexto ano não possui o mesmo material dos livros das outras séries, tendo, assim, páginas impressas em uma folha com qualidade inferior às demais. Os outros livros da coleção possuem material semelhante à coleção anterior. As capas possuem uma palheta de cores parecidas entre toda a coleção, com algumas alterações em imagens para cada ano letivo (números, figuras geométricas, esquadros e objetos matemáticos em folha quadriculada). 


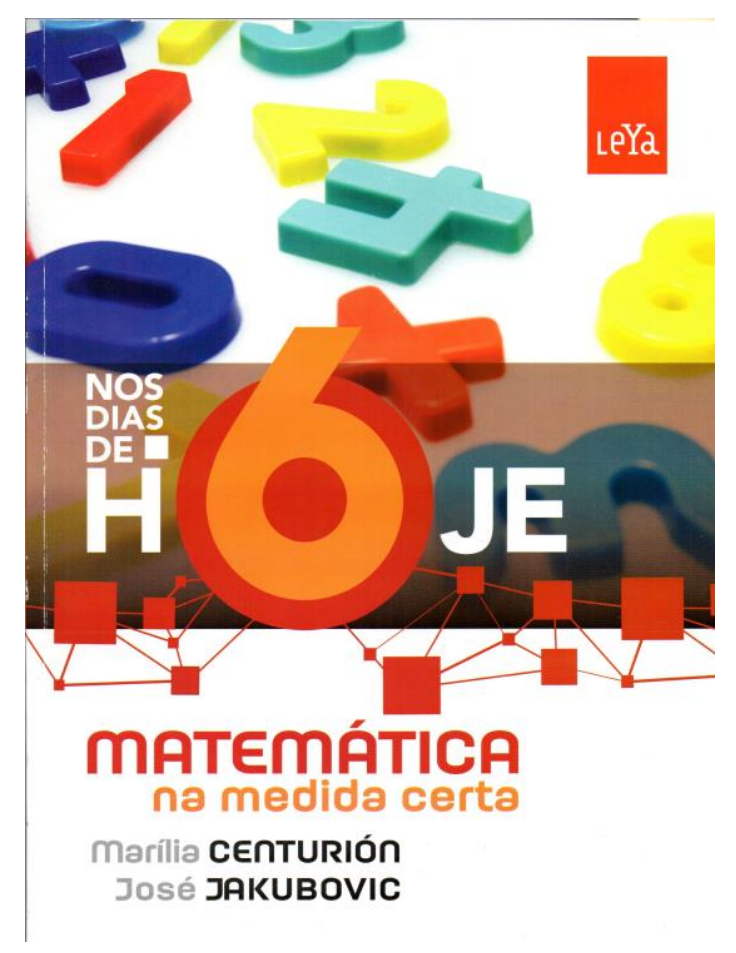

Figura 37 - Capa Matemática na medida certa 6

Cada livro é dividido em oito capítulos e vários paratextos, como "conheça seu livro", sumário, respostas das atividades e referências bibliográficas. As aberturas de cada capítulo apresentam textos e imagens que remetem ao assunto estudado, com aplicações e contextos históricos, além de uma lista com todos os conteúdos apresentados no capítulo. 


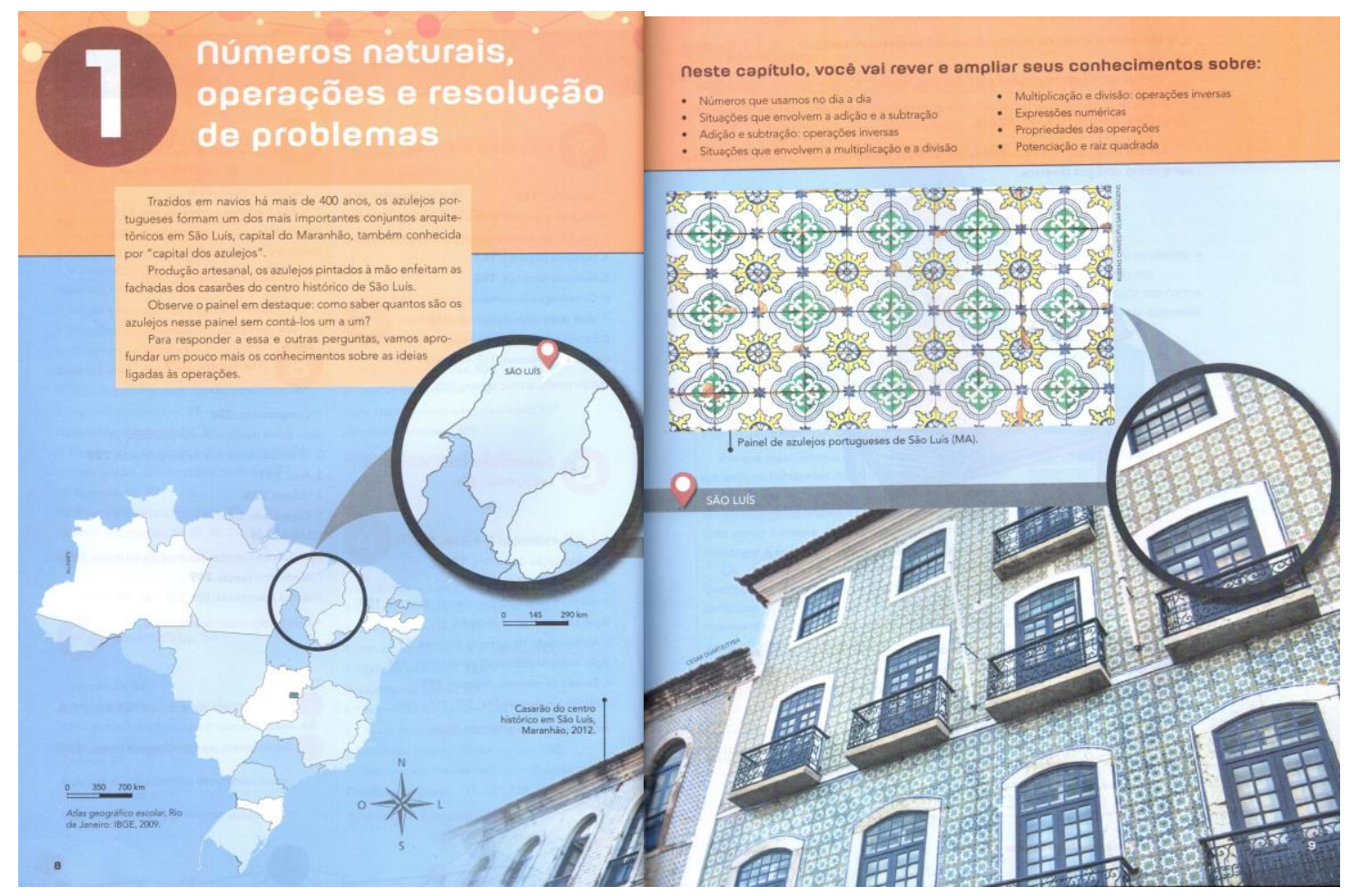

Figura 38 - Matemática na medida certa 6 - p. 8 e 9

Inserido nos capítulos, temos algumas seções específicas, como teoria, exercícios, conexões (contextualização com o cotidiano), ação (seção semelhante à oficina, com atividades em grupo), desafios, "você sabia que" (com curiosidades sobre o tema estudado), "pensando em casa" (exercícios com todos os temas do capítulo) e "revendo conceitos" (semelhante ao "pensando em casa", mas com uma quantidade reduzida de exercícios).

Os capítulos seguem um padrão já estabelecido em diversos livros didáticos, iniciando com a teoria escrita, seguida de alguns exemplos, lista de exercícios e algum desafio ou oficina, chamada de "ação". A lista de exercícios é extensa, o que aumenta a variedade de aplicações para o tema em questão.

Fontes e cores de letras não se alteram com frequência ao longo dos livros, transmitindo mais formalidade. As imagens coloridas realizam o papel de "quebrar" a estrutura de cores dos textos (preto, laranja e vermelho).

Realizando uma breve comparação com a coleção anterior, nota-se a falta do paratexto "glossário" e de "materiais complementares", como planificações de objetos tridimensionais ou malha quadriculada. 


\subsubsection{Matemática na medida certa 6}

O primeiro livro da coleção possui um total de 280 páginas, divididas em 8 capítulos, nos quais 2 são voltados para o estudo de geometria. Num total de 252 páginas, 80 delas estão destinadas a abordar geometria (retirando os paratextos "apresentação", "conheça seu livro", "sumário", "respostas das atividades" e "referências bibliográficas", que somam 28 páginas).

No segundo capítulo do livro, intitulado "Geometria", os autores abordam os conteúdos de ângulos, figuras geométricas planas, espaciais e simetria. No início do capítulo é apresentada uma imagem da obra do autor Milton Dacosta (1915-1988), na qual é possível observar o uso de diversas formas geométricas, incluindo ferramentas de uso na geometria (como um esquadro).

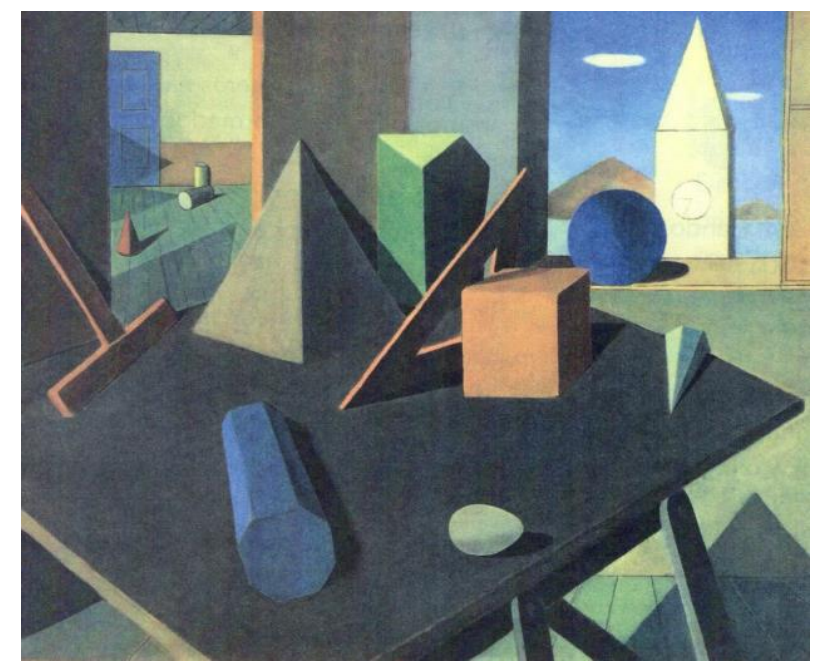

Figura 39 - Matemática na medida certa 6 - p. 54

As definições de ponto, segmento de reta, semirreta, reta e plano são apresentadas juntamente com imagens, mas sem a utilização de ferramentas geométricas, como régua. Retas concorrentes e paralelas são apresentadas em apenas três linhas, com uma imagem para cada tipo. Durante a seção de exercícios não é observada a utilização de desenho geométrico.

Dando continuidade ao capítulo, o próximo tema abordado é ângulos. Com isso, as ferramentas transferidor e esquadro são inseridas. Esse último, inclusive, como primeiro exemplo e definição de ângulos. O transferidor é retratado de duas maneiras no livro: transferidores que medem ângulos de até $180^{\circ}$ e transferidores 
que medem ângulos de até $360^{\circ}$. Trazer a informação da diferença entre eles é interessante, algo que não foi abordado na coleção anterior. No capítulo não é apresentado a criação de ângulos, apenas a medição e a classificação.

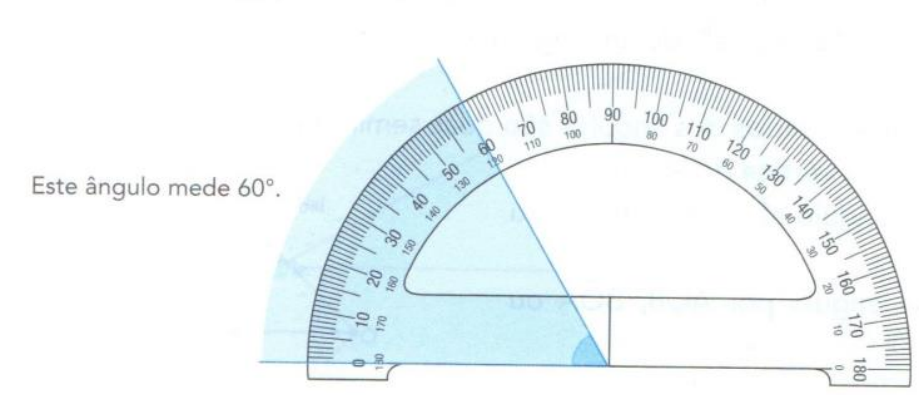

Figura 40 - Matemática na medida certa 6 - p. 62

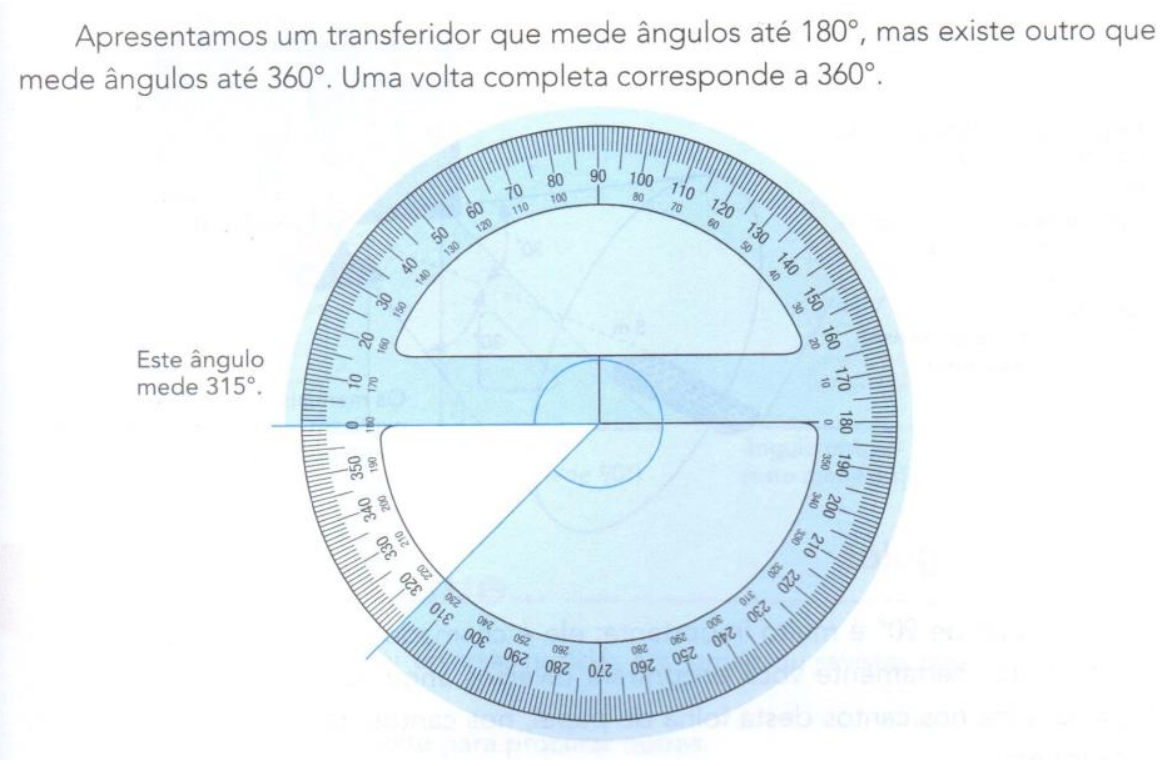

Figura 41 - Matemática na medida certa 6 - p. 63

Na seção "pense e responda" encontramos dez exercícios, mas em apenas um deles o transferidor é necessário, já que em outros ele já é apresentado no próprio exercício, fato que também ocorre com os esquadros. O exercício em questão é bem simples, é pedido para os alunos medirem alguns ângulos dados, como mostra a figura: 
5. Use o transferidor e dê a medida dos ângulos mostrados a seguir.

a)

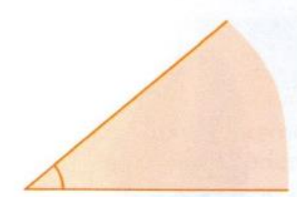

b)

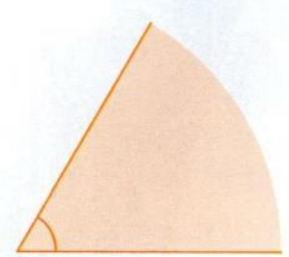

c)

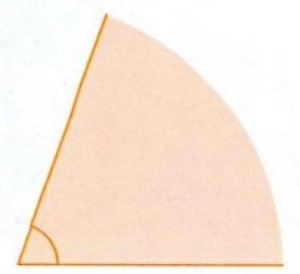

Figura 42 - Matemática na medida certa 6 - p. 66

Nas duas seções seguintes são apresentados alguns polígonos, como triângulos e quadriláteros, e também circunferências. A apresentação é feita através de imagens, definições e classificações, mas as construções dessas figuras geométricas não são abordadas. Assim, os alunos trabalham com as figuras prontas, analisando características e classificando-as. Em alguns exercícios sobre triângulos são utilizados régua e transferidor, mas o assunto não é aprofundado.

As últimas seções no capítulo abordam figuras geométricas espaciais e simetria, e construção geométrica não foi utilizada. Durante os exercícios de revisão, intitulados "pensando em casa", observamos o mesmo modelo de exercício utilizando o transferidor, ainda sem abordar a criação de ângulos.

O oitavo, e último, capítulo do livro a abordar o tema geometria é intitulado "Medidas", e apresenta os conteúdos de área, volume, massa e medidas de tempo. A única utilização de alguma ferramenta geométrica durante todo o capítulo foi na medida de comprimento e largura de formas geométricas, espaços físicos ou afins. Desenho geométrico não foi citado ou utilizado de nenhuma forma. 
O livro do sexto ano da coleção Matemática na medida certa não apresenta muitos conteúdos de geometria e, consequentemente, de desenho geométrico. Durante todo o livro não foi encontrado nenhum exemplo da utilização de régua e compasso, nem construção de figuras geométricas, mesmo que empregando métodos alternativos. Espera-se que ao longo da coleção o tema seja abordado.

\subsubsection{Matemática na medida certa 7}

O segundo livro da coleção Matemática na medida certa possui 271 páginas distribuídas em 8 capítulos, nos quais 2 deles são focados em geometria, o 5 e o 8응 (Tópicos de Geometria e Unidades de medida, respetivamente). Os 2 capítulos, juntos, possuem 62 páginas, incluindo teorias, exercícios, figuras e todos os paratextos já apresentados no livro anterior. Como já informado anteriormente, o material das páginas dos livros dos $7^{\circ}, 8^{\circ}$ e $9^{\circ}$ anos são diferentes do livro anterior (e semelhante a coleção anterior, projeto Teláris).

O primeiro capítulo intitulado Tópicos de Geometria aborda os assuntos: ângulos, sistema cartesiano, simetrias e construção de figuras geométricas. As três primeiras seções do capítulo revisam e aprimoram o conhecimento em ângulos, mas ainda sem abordar a construção deles. Esquadros e transferidores já são utilizados, mas com pouca frequência, ainda que o desenho do transferidor é apresentado no próprio exercício (como visto na figura 40). De uma lista de oito exercícios, o transferidor físico só é necessário em um deles. Para os demais exercícios, o conhecimento algébrico é o suficiente.

\section{Pense e responda}

1. Quanto medem os seguintes ângulos?
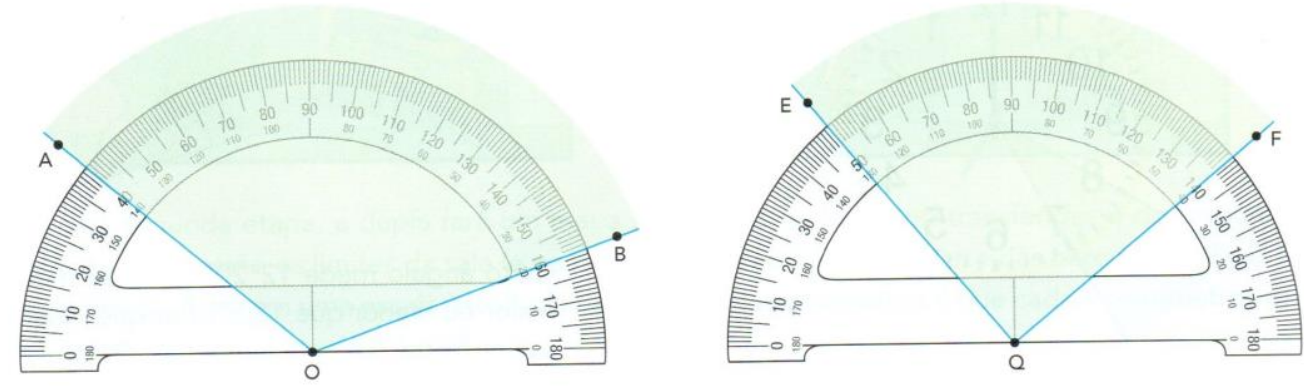

Figura 43 - Matemática na medida certa 7 - p. 163 
2. Agora, com um transferidor, meça estes ângulos:

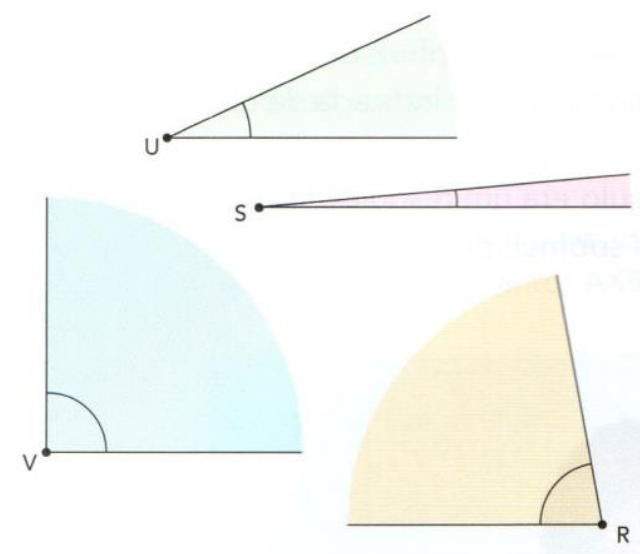

Figura 44 - Matemática na medida certa 7 - p. 164

A quarta seção aborda a localização de pontos no plano cartesiano, logo, é esperado não encontrar nenhum conceito de desenho geométrico envolvido. $\mathrm{Na}$ seção simetria axial, os conceitos de mediatriz de um segmento e bissetriz de um ângulo são abordados, mas sem a utilização de régua e compasso. Em vez disso, os autores utilizam dobraduras em uma folha de papel, o que torna a construção desses segmentos imprecisa. Durante o texto não é mencionado outras formas de encontrar tais segmentos.

\section{Eixo de simetria de um segmento}

Vamos usar a ideia de dobrar a figura para encontrar o eixo de simetria de um segmento de reta $\overline{\mathrm{AB}}$ : dobrando, o ponto $\mathrm{A}$ deve cair sobre o ponto $\mathrm{B}$.

Note que não estamos tratando do eixo de simetria da folha de papel que será dobrada e sim do eixo de simetria do segmento em questão. Veja abaixo.

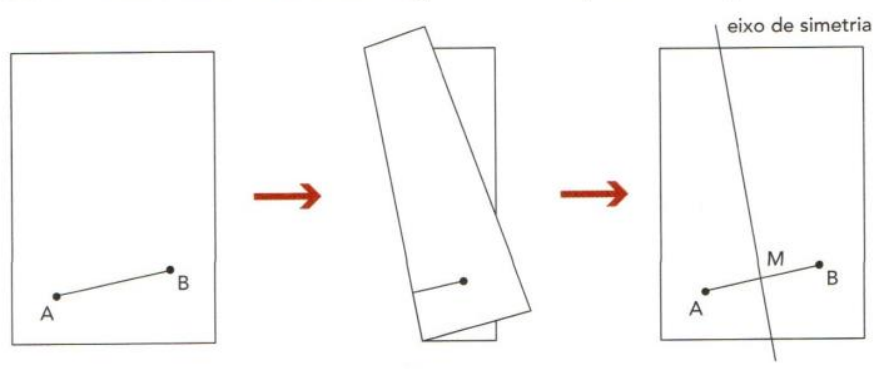

Figura 45 - Matemática na medida certa 7 - p. 176.1 


\section{Eixo de simetria de um ângulo}

Imagine um ângulo desenhado em uma folha de papel. Você faz uma dobra de maneira que os lados do ângulo coincidam e depois desdobra. A linha de dobra será o eixo de simetria do ângulo.

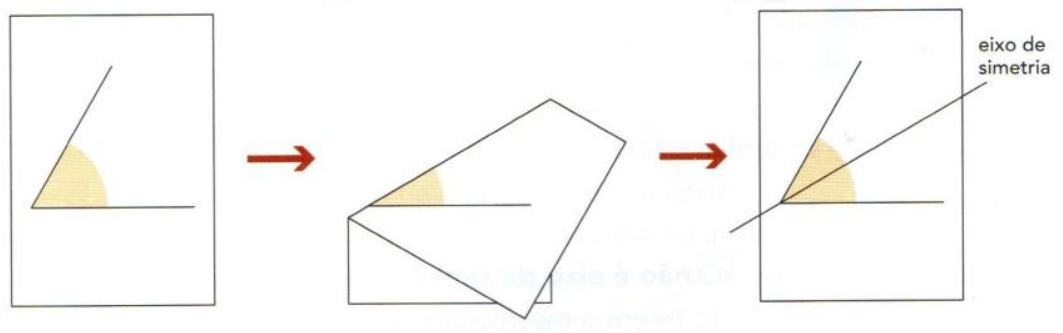

Figura 46 - Matemática na medida certa 7 - p. 176.2

A sétima seção do capítulo, chamada "Construção de polígonos regulares" apresenta a construção de três figuras geométricas: pentágono, quadrado e triângulo, todos regulares. Para isso os autores utilizam régua, compasso, transferidor e esquadros. O primeiro caso apresentado é o pentágono regular. Nele, os autores não mostram o método tradicional de se construir o pentágono, mas sim um método simplificado, no qual os alunos utilizam o transferidor para encontrar os ângulos centrais do polígono e, na sequência, ligam os pontos encontrados. Tal método, tradicionalmente não é considerado construção geométrica, mas como uma introdução, é viável. 


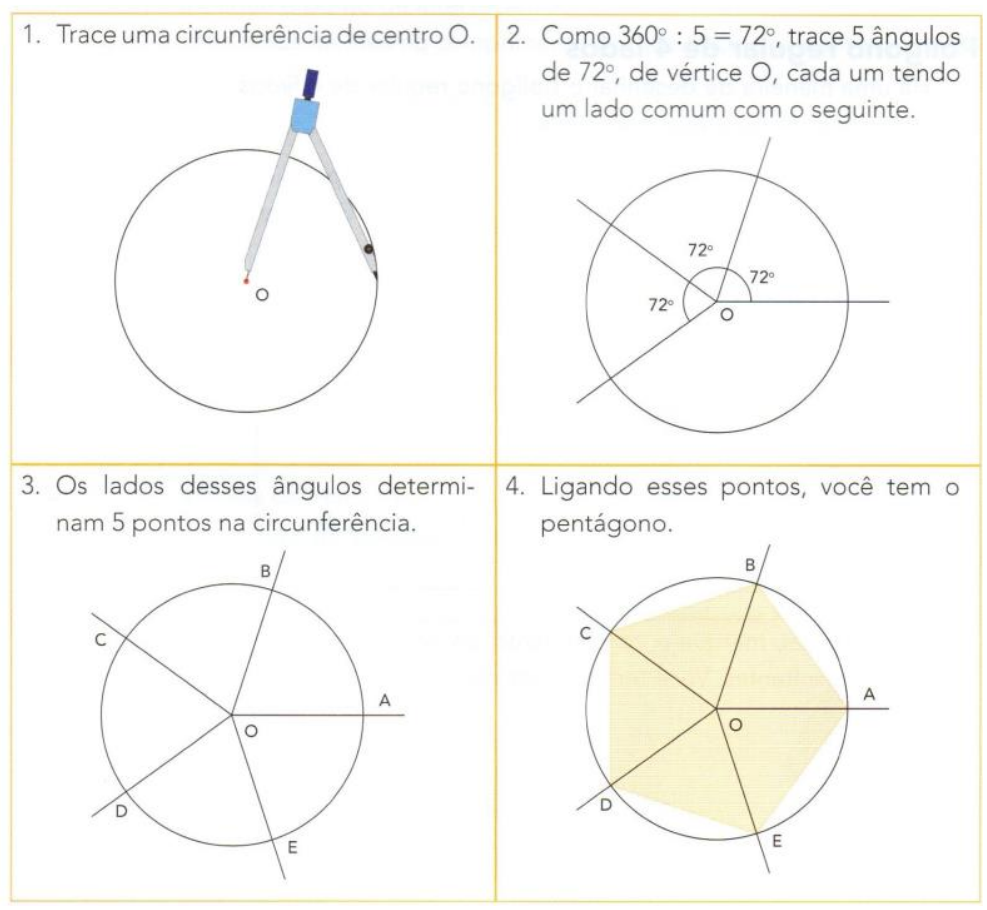

Figura 47 - Matemática na medida certa 7 - p. 181

O segundo caso apresentado é a construção do quadrado. Nele também observamos uma metodologia diferente da tradicional, pois utiliza-se esquadro e régua, não compasso. O método apresentado também pode ser utilizado para construir retângulos.

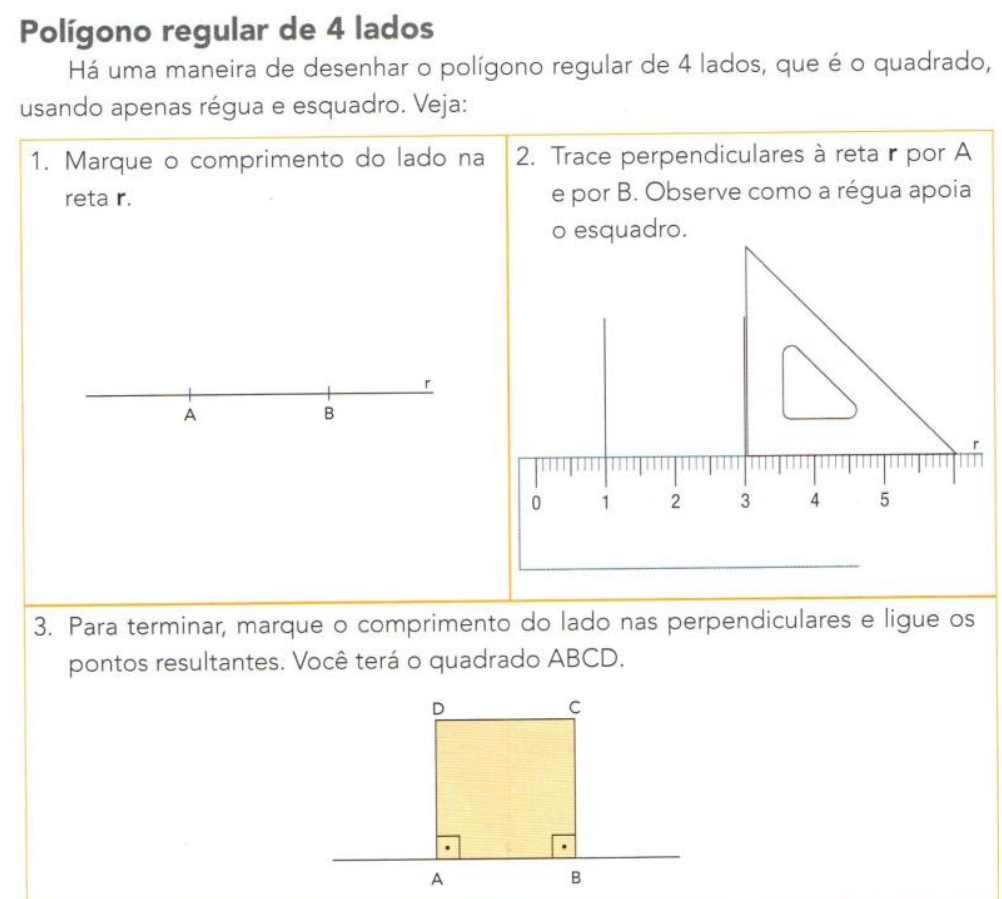

Figura 48 - Matemática na medida certa 7 - p. 182 
A última construção é do triângulo equilátero. Nela observamos a utilização de régua e compasso e, diferentemente dos casos anteriores, a construção é a tradicional, em que dado um segmento é possível construir dois arcos (cada qual no centro em uma das extremidades do segmento) e ligar o seu ponto de intersecção com as extremidades dadas.

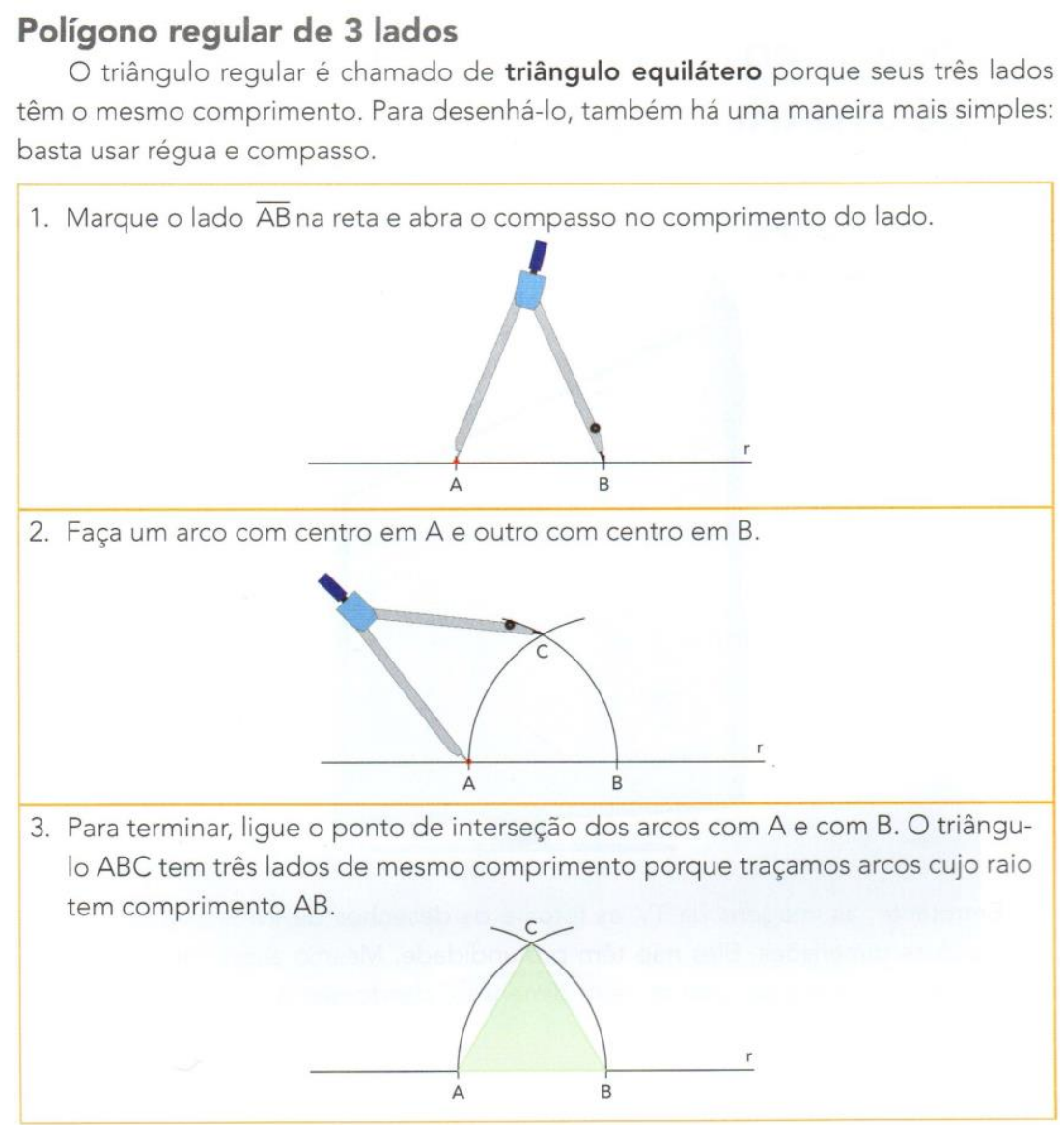

Figura 49 - Matemática na medida certa 7 - p. 183.1

Na seção "pense e responda" são propostos cinco exercícios para treinar as construções apresentadas no capítulo. Todas seguem os modelos dos exemplos, sem apresentar nenhuma incoerência. As construções, mesmo não tradicionais, são relevantes, pois é o primeiro contato do aluno com esse conteúdo, já que no livro anterior não foi abordado. 
1. Use o método explicado no texto e trace um polígono regular de 9 lados, começando com uma circunferência de $5 \mathrm{~cm}$ de raio.

Quanto mede o lado do polígono que você desenhou?

2. Usando régua e esquadro, desenhe um quadrado $A B C D$ com $A B=4,5 \mathrm{~cm}$. Depois, dê a medida aproximada da diagonal $\overline{A C}$ desse quadrado.

3. Com um compasso, trace um triângulo equilátero $A B C$ com lados de $4 \mathrm{~cm}$. Depois, usando o transferidor, diga quanto mede cada um de seus ângulos internos.
4. Quantos lados tem o polígono regular cujos ângulos centrais medem $15^{\circ}$ ?

5. Pensando nas simetrias do polígono e sabendo que o hexágono regular tem ângulos de $120^{\circ}$,

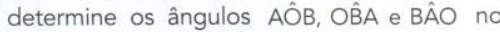
hexágono regular da figura abaixo.

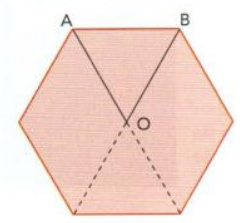

Figura 50 - Matemática na medida certa 7 - p. 183.2

O oitavo e último capítulo do livro, "Unidades de medida", aborda os conceitos de comprimento, área, volume e problemas envolvendo tais grandezas. Durante o capítulo não foi abordado o conteúdo de construção geométrica em nenhum caso.

Ao término do livro percebe-se um crescimento do conteúdo de construção geométrica em relação ao primeiro, mesmo sem aproveitar algumas oportunidades, como mediatriz e bissetriz, ou com construções não tradicionais, como do pentágono regular ou quadrado.

\subsubsection{Matemática na medida certa 8}

O livro destinado aos alunos do $8^{\circ}$ ano possui um total de 256 páginas, divididas em 8 capítulos (como todos os livros da coleção). Três capítulos são focados no estudo da geometria, sendo eles o $5^{\circ}, 6^{\circ}$ e $7^{\circ}$ (Grandezas e medidas; os polígonos; Construções geométricas, respectivamente). Somando os 3 capítulos, temos um total de 98 páginas referentes à geometria.

O $1^{\circ}$ dos 3 capítulos aborda medidas, grandezas, unidades de medida e sistema internacional de unidades. Nesse capítulo não é abordado o tema construção geométrica, porém em dois exercícios da seção "pensando em casa" pede-se que $\mathrm{o}$ aluno construa um retângulo e, para isso, utiliza-se o método abordado no livro anterior, com régua e esquadro. Novamente, esse método não se adequa à construção geométrica tradicional, mas não podemos rejeitar tal utilização, pois trata-se de uma introdução ao conteúdo. 
4. Desenhe no caderno um retângulo com $8 \mathrm{~cm}$ de largura e cuja altura é $\frac{3}{4}$ da medida da largura.

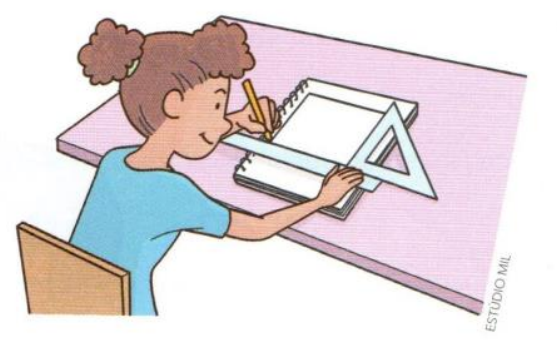

a) Quais são as dimensões desse retângulo?

b) Qual é o perímetro desse retângulo?

c) Quanto mede a área do retângulo?

Figura 51 - Matemática na medida certa 8 - p. 130.1

5. Observe a figura a seguir e, depois, faça o que se pede em cada item.

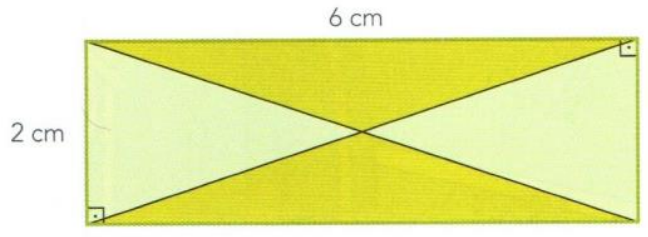

a) Faça uma estimativa e responda: você acha que o retângulo foi dividido em 4 partes de mesma área?

b) Agora, desenhe em um papel sem pauta um retângulo com as dimensões $6 \mathrm{~cm}$ e $2 \mathrm{~cm}$. Trace, com a ajuda de uma régua, as diagonais desse retângulo. A seguir, a partir dos pontos médios dos lados, trace os dois eixos de simetria do retângulo (já que as diagonais não são eixos de simetria, como já estudamos). Recorte os 8 triângulos obtidos e verifique se as áreas são iguais.

Figura 52 - Matemática na medida certa 8 - p. 130.2

O $2^{\circ}$ dos 3 capítulos aborda a soma das medidas dos ângulos internos de polígonos, triângulos congruentes e classificação dos quadriláteros. Nas páginas de apresentação do capítulo temos uma imagem do livro "Elementos" em uma versão de 1660, preparada pelo matemático Isaac Barrow. Além da imagem, os autores trazem um texto, explicando de forma simples a importância da obra para a matemática, como vemos a seguir. 
As noções que você vai estudar neste capítulo têm aplicação nas construções mais variadas: casas, pontes, edifícios, armários, máquinas etc. Até nos ladrilhos de um piso você encontra geometria.

Essas noções também têm valor histórico. Faziam parte do livro mais famoso da Matemática, o Elementos, escrito pelo matemático grego Euclides de Alexandria, por volta do ano 300 a.C.

O livro de Euclides não mostra nenhuma utilidade das noções estudadas. Sua importância está em provar todas as afirmações, exceto alguns fatos básicos, que Euclides provavelmente considerava óbvios. Assim, se Euclides afirmava que certo ângulo de algum triangulo era um ângulo reto, ele provava esse fato, com um raciocínio lógico, sem fazer qualquer medida. Esse procedimento tornou-se padrão na Matemática: todos os fatos têm um porquê e devem ser provados usando fatos já conhecidos anteriormente. (CENTURIÓN, M; JAKUBOVIC, J., 2015, p. 136)

A primeira seção do capítulo traz a construção de um tangram, mas não utiliza construção geométrica, e sim dobraduras realizadas em um quadrado de cartolina, com lado de $16 \mathrm{~cm}$. Todas as etapas são apresentadas com figuras no livro. Os conteúdos de ponto médio de um segmento e bissetriz também são abordados, mas, novamente, os autores optam por não utilizar a construção geométrica para encontrá-las.

\section{Ponto médio de um segmento \\ $\mathrm{M}$ é o ponto médio de um segmento $\overline{\mathrm{RS}}$ quando o divide em dois segmentos congruentes, ou seja: $\overline{\mathrm{RM}} \equiv \overline{\mathrm{MS}}$.

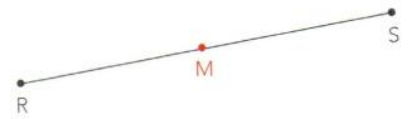 \\ M é o ponto médio de $\overline{\mathrm{RS}}$ \\ $\overline{\mathrm{RM}} \equiv \overline{\mathrm{MS}}$ \\ $(\overline{\mathrm{RM}}$ é congruente a $\overline{\mathrm{MS}})$ \\ Bissetriz de um ângulo \\ Bissetriz de um ângulo é a semirreta que o divide em dois ângulos congruentes.}

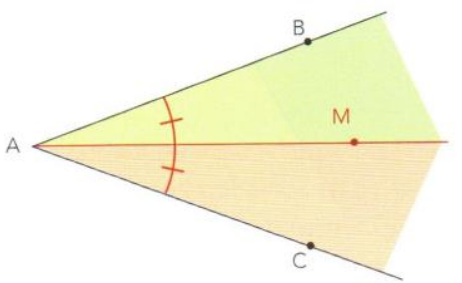

$\overrightarrow{\mathrm{AM}}$ é bissetriz de $\mathrm{BÂC}$

$B \hat{M} M \equiv M A \hat{C}$

(BÂM é congruente a MÂC)

Figura 53 - Matemática na medida certa 8 - p. 143

Na próxima seção - ângulos formados por paralelas e transversais - os autores orientam na construção de retas paralelas, mas usando régua e esquadros, e não compasso como na construção geométrica tradicional. Tais orientações são realizadas em exemplos (figura 51) e exercícios (figura 52), não em texto teórico. 


\section{Exemplos}

1. Podemos traçar retas paralelas fazendo ângulos correspondentes congruentes

Veja:

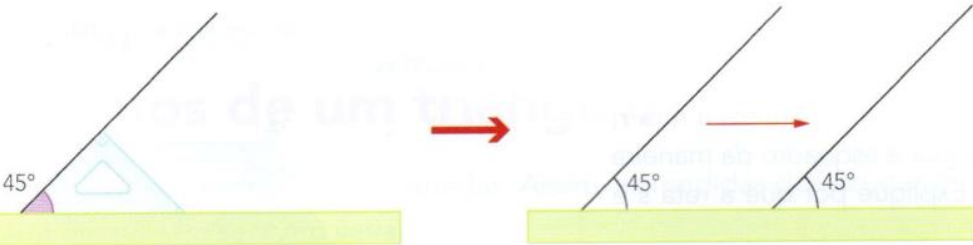

Com um esquadro sobre uma régua pode-se desenhar um ângulo de $45^{\circ}$. Desliza-se o esquadro e faz-se outro ângulo de medida igual. As retas representadas são paralelas.

Figura 54 - Matemática na medida certa 8 - p. 151

2. Para traçar por um ponto $P$ a paralela à reta $r$, podemos utilizar régua e esquadro da maneira ilustrada a seguir. Explique por que a reta s é paralela a $\mathbf{r}$.
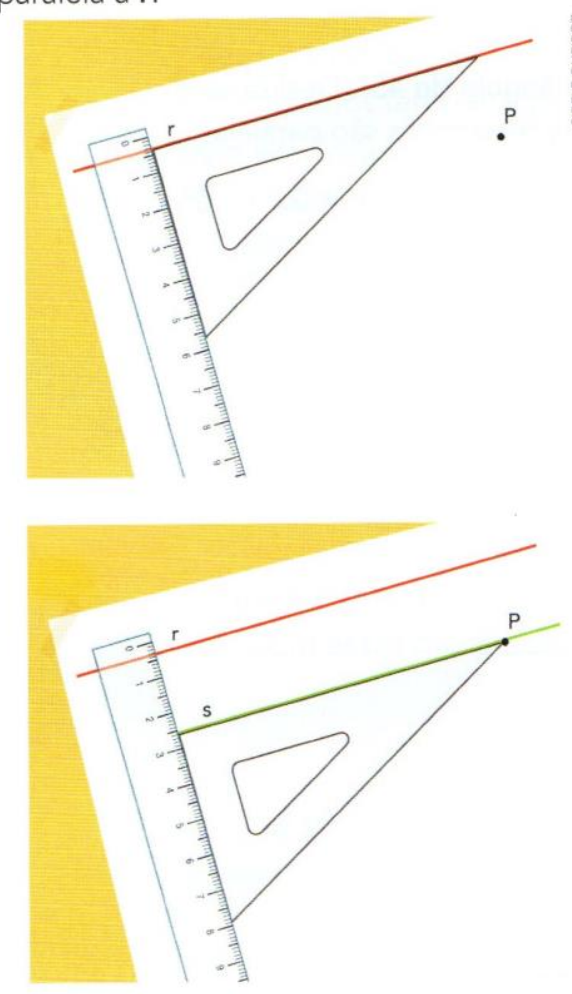

Figura 55 - Matemática na medida certa 8 - p. 152

O restante do capítulo não aborda o tema desejado, mas o terceiro, e último, capítulo focado em geometria (construções geométricas) traz como conteúdo o estudo das circunferências e construção de figuras planas e espaciais. 
Durante as duas primeiras seções do capítulo não observamos a utilização de ferramentas ou construções geométricas, mesmo com o tema circunferência. Em nenhum momento (incluindo os exercícios da seção) os alunos precisarão construir uma circunferência ou os ângulos relacionados a elas.

A terceira seção revisa a construção de polígonos regulares vista no livro anterior, inscrevendo-os em uma circunferência e dividindo seu ângulo central pela quantidade de lados do polígono desejado.

\section{Construção de figuras geométricas planas}

Este item e os próximos tratam das construções geométricas, isto é, de desenhar figuras geométricas com instrumentos como régua e compasso. Assim, você reforça conhecimentos de geometria, além de adquirir noções e desenvolver habilidades que poderão ser muito úteis.

\section{Construção de polígonos regulares}

A construção de um polígono regular de $\mathbf{n}$ lados baseia-se na construção de uma circunferência e na divisão, em $\mathbf{n}$ partes iguais, do ângulo central de $360^{\circ}$

Os triângulos formados são todos congruentes, pelo caso LAL. Como eles são triângulos isósceles, vamos indicar por $\mathbf{x}$ a medida dos ângulos das suas bases.
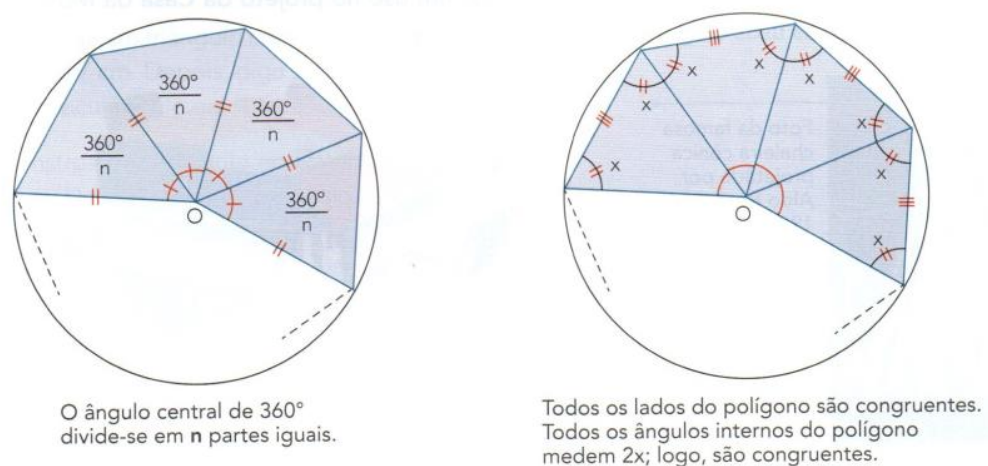

Forma-se, portanto, um polígono regular de $\mathbf{n}$ lados.

Nessa construção, dizemos que o polígono regular está inscrito numa circunferência.

Figura 56 - Matemática na medida certa 8 - p. 195

Além dos polígonos regulares, é apresentada a construção de triângulos, com medidas dos lados conhecidos. A apresentação é próxima à tradicional, utilizando régua graduada e compasso, como vemos na figura a seguir. 


\section{Construção de um triângulo conhecendo-se os lados}

Vamos mostrar a construção de um triângulo com lados de $2 \mathrm{~cm}, 3 \mathrm{~cm}$ e $4 \mathrm{~cm}$. Para isso, usaremos régua e compasso.

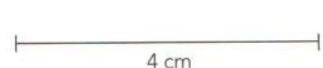

Trace o lado maior.

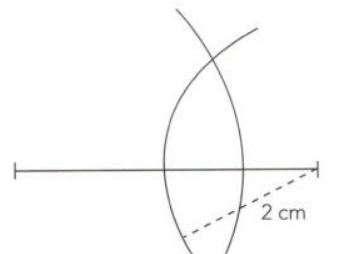

Com centro na outra extremidade, trace uma circunferência com $2 \mathrm{~cm}$ de raio, para obter o lado de $2 \mathrm{~cm}$.

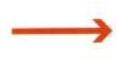

Com centro numa extremidade do lado, trace uma circunferência com raio de $3 \mathrm{~cm}$, para obter o lado de $3 \mathrm{~cm}$.

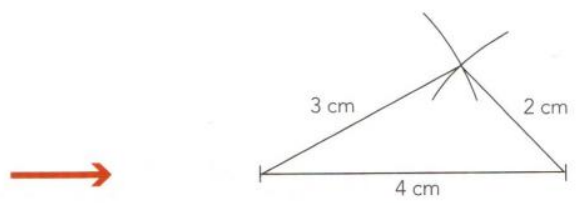

Ligue o ponto de intersecção das circunferências com os extremos do segmento. Pronto!

Figura 57 - Matemática na medida certa 8 - p. 196

Na seção "pense e responda" temos uma lista com 6 exercícios, nos quais 5 deles são voltados à construção das figuras apresentadas nas páginas anteriores. Na sequência, temos dois exemplos de exercícios.

3. Construa um triângulo com lados medindo $4 \mathrm{~cm}$, $5 \mathrm{~cm}$ e $7 \mathrm{~cm}$. Depois, diga se o triângulo é retângulo, acutângulo ou obtusângulo.

4. Construa um triângulo equilátero com lados de $4 \mathrm{~cm}$. Depois, meça cada ângulo interno do triângulo.

Figura 58 - Matemática na medida certa 8 - p. 197

Após abordar por diversas vezes os conteúdos de mediatriz e bissetriz, os autores apresentam as construções da mediatriz de um segmento e bissetriz de um ângulo, ambas com a utilização de régua e compasso. Segue abaixo os passos da construção geométrica tradicional. 


\section{Mediatriz de um segmento e outras construções}

Se você sabe construir um triângulo comum, também sabe construir um triângulo isósceles e mesmo um losango. Observe:

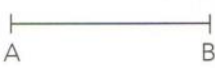

Desenhe o segmento de reta $\overrightarrow{A B}$

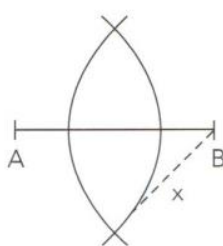

Repita a construção com centro em B.

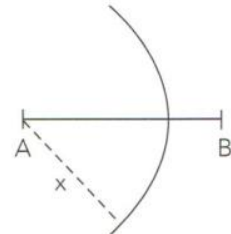

Com centro em $\mathrm{A}$, trace um arco com abertura maior que a metade de $\overline{\mathrm{AB}}$.

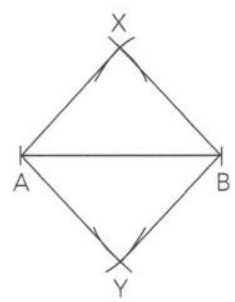

Como você usou o mesmo raio, $\overline{\mathrm{AX}} \equiv \overline{\mathrm{XB}} \equiv \overline{\mathrm{AY}} \equiv \overline{\mathrm{BY}}$.

Repare que acima e abaixo de $\overline{\mathrm{AB}}$ você obteve triângulos isósceles: são $\triangle A X B$ e $\triangle A Y B$. Além do mais, $A X B Y$ é um losango.

E a mediatriz? Bem, se você quiser somente ela, basta ligar $X$ e $Y$ na sua construção.

Como a reta $\overrightarrow{X Y}$ é eixo de simetria do losango (e dos triângulos $A X B$ e $A Y B$ também), ela também é mediatriz de $\overline{A B}$.

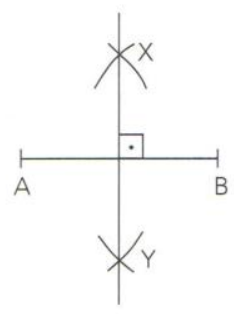

Figura 59 - Matemática na medida certa 8 - p. 198.1

\section{Construção da bissetriz de um ângulo}

Veja como se constrói a bissetriz:

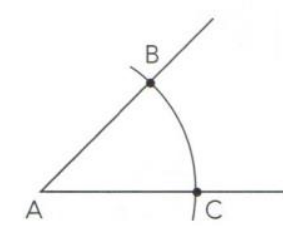

Com centro em A, trace um arco de circunferência que corte os lados do ângulo em $B$ e $C$. Assim, $\overline{A B} \equiv \overline{A C}$
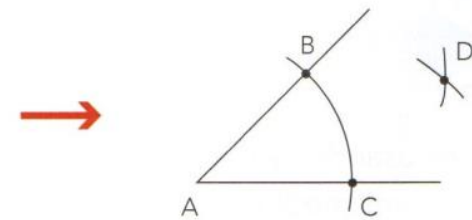

Com centros em B e C, trace dois arcos de circunferência com raios de mesma medida, que se cruzem em D. Assim, o ponto D é equidistante de $\mathrm{B}$ e $\mathrm{C}$.

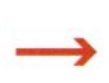

Ligue A com D. A semirreta $\overrightarrow{A D}$ é a bissetriz.

Figura 60 - Matemática na medida certa 8 - p. 198.2

Além disso, na seção "pense e responda", dois exercícios interessantes são apresentados, o primeiro pede a construção de um losango, polígono que não foi explicitamente apresentado, mas que, com os conhecimentos adquiridos é possível 
construir. E o segundo pede para construir um triângulo qualquer e encontrar a mediatriz dos três lados, mesmo não abordando o assunto circuncentro, dá a oportunidade da descoberta por parte dos alunos.

2. Construa um losango cujas diagonais meçam $6 \mathrm{~cm}$ e $5 \mathrm{~cm}$.

3. Trace um triângulo qualquer, usando apenas régua. Depois, trace as mediatrizes de cada um de seus lados. Haverá uma grande coincidência. Você sabe dizer qual é?

Figura 61 - Matemática na medida certa 8 - p. 199

A última seção do capítulo é reservada para a construção de figuras espaciais, mas não aborda construção geométrica, apenas planificações já construídas. No término do capítulo temos a seção "pensando em casa", com exercícios referentes aos conteúdos de todo o capítulo. Nela, alguns exercícios se destacam, como os itens 20 e 22.

20. Construa um triângulo escaleno com todos os lados medindo mais de $3 \mathrm{~cm}$. Trace as bissetrizes dos três ângulos do triângulo.

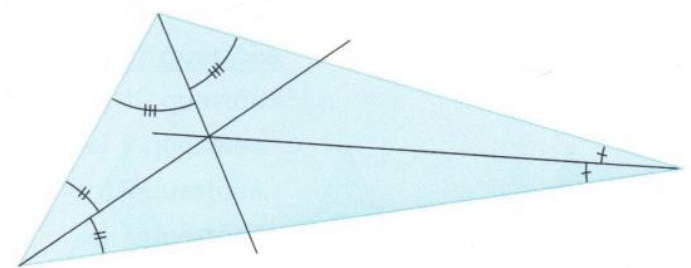

Se seu trabalho foi bom, as três bissetrizes se cortam em um mesmo ponto. Se isso não acontecer, refaça o desenho.

Figura 62 - Matemática na medida certa 8 - p. 209.1

22. Desenhei um triângulo $A B C$. Quero traçar uma circunferência que passe por $A, B$ e $C$. Como acho o centro dessa circunferência?

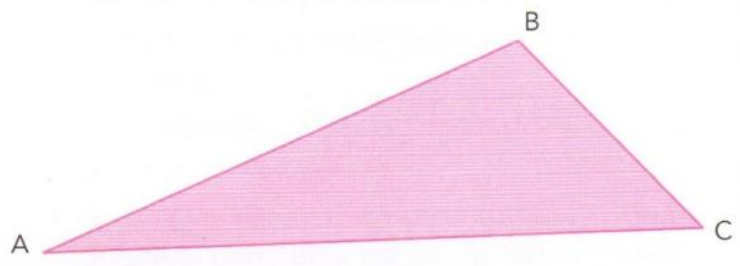

Figura 63 - Matemática na medida certa 8 - p. 209.2 
O primeiro deles pede a construção das três bissetrizes dos ângulos de um triângulo, encontrando, assim, o incentro, mas não utilizando seu nome e nem suas características, deixando novamente a descoberta para o aluno. O segundo traz uma informação não apresentada anteriormente, em que as mediatrizes das cordas de uma circunferência também são eixos de simetria da circunferência, isto é, passam pelo centro. E por último, temos a construção de uma circunferência que passa pelos três vértices do triângulo, ou seja, o aluno precisa encontrar o centro dessa circunferência e, para isso, precisa do conhecimento adquirido no exercício da seção, no qual encontrou o circuncentro.

O livro do oitavo ano é, de fato, o que mais utilizou as construções geométricas, trazendo construções que faltaram nos livros anteriores, como mediatriz e bissetriz. As construções de polígonos regulares são interessantes, pois possibilita que os alunos construam até mesmo quadrados, utilizando um método mais próximo do habitual, e não com régua e esquadro. Oportunidades ainda foram perdidas, como a construção de retas paralelas.

\subsubsection{Matemática na medida certa 9}

O último livro da coleção "Matemática na medida certa" possui 264 páginas, distribuídas em 8 capítulos e paratextos. Quatro capítulos abordam de algum modo o tema geometria, tornando, assim, o livro com mais capítulos sobre o tema. Somando todos os capítulos da área, temos 108 páginas, tornando-o também o livro com o maior número de páginas focadas em geometria.

O primeiro capítulo do livro (Geometria: ampliações e reduções), além de abordar os assuntos já mencionados no título, retoma o tema proporções, figuras semelhantes e cálculo de distâncias inacessíveis.

Observamos a utilização de construção geométrica na seção de semelhança de triângulos, no qual os autores relembram a construção de um triângulo qualquer utilizando régua e compasso. Além disso, não há mais utilizações, nem mesmo na seção sobre teorema de Tales, em que é possível inserir a construção de retas paralelas. 


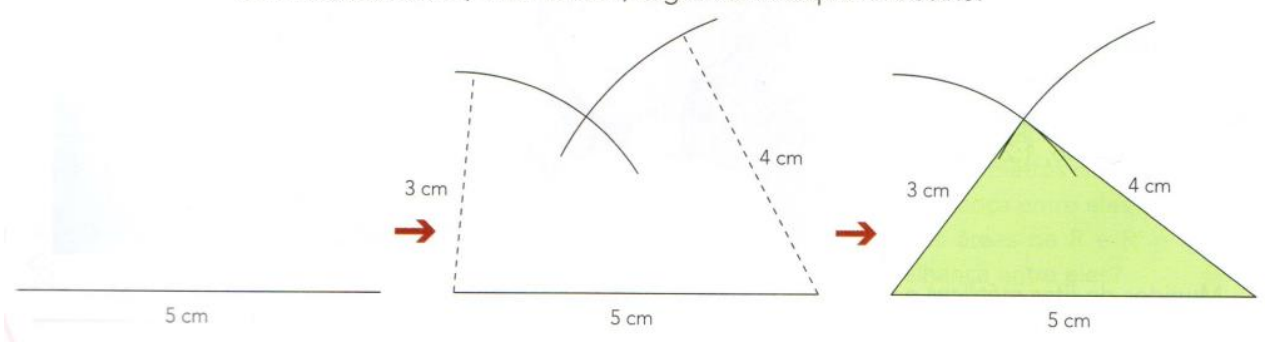

Figura 64 - Matemática na medida certa 9 - p. 16

O quarto capítulo do livro, segundo sobre geometria, aborda o teorema de Pitágoras e outras relações métricas no triângulo retângulo. Do mesmo modo que o capítulo anterior, não é observado a utilização de construção geométrica, mas, alguns conteúdos do capítulo poderiam ser desenvolvidos com o uso da construção geométrica, como a obtenção da altura de um triângulo e retas tangentes e secantes na circunferência.

O capítulo seguinte continua a tratar de conteúdos já vistos, introduzindo as noções básicas da trigonometria, mas também não abordando a construção geométrica. Na quarta seção do capítulo vemos as relações métricas em polígonos regulares inscritos, mas não é pedido nenhum desenho por parte do aluno, portanto não é necessário a utilização de régua ou compasso. 


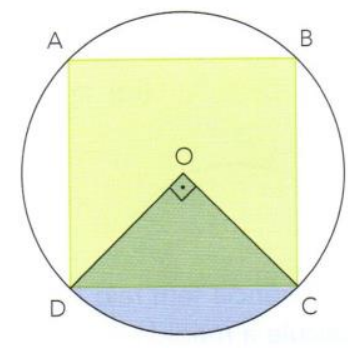

No quadrado inscrito na circunferência o ângulo central mede $360^{\circ}: 4=90^{\circ}$.

Portanto, o triângulo $O C D$ é retângulo e isósceles.

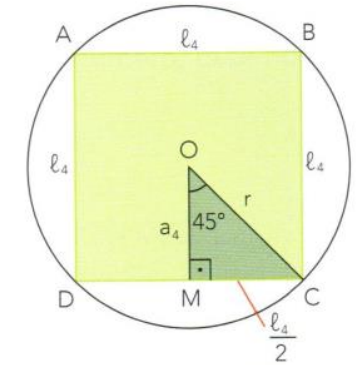

Traçando o apótema $\overline{\mathrm{OM}}$, temos ainda um triângulo isósceles: OCM. Portanto, $\mathrm{a}_{4}=\frac{\ell_{4}}{2}$.

Vamos considerar que $\ell_{4}=5 \mathrm{~cm}$. Quanto medirá o apótema e o raio da circunferência?

- $a_{4}=\frac{5}{2} \mathrm{~cm}$, como observado acima.

- $\operatorname{sen} 45^{\circ}=\frac{\frac{\ell_{4}}{2}}{r} \Rightarrow \frac{\sqrt{2}}{2}=\frac{\frac{5}{2}}{r} \Rightarrow \sqrt{2}=\frac{5}{r}$.

Portanto, $r \sqrt{2}=5$ e temos $r=\frac{5}{\sqrt{2}}=\frac{5 \sqrt{2}}{2}$. Ou seja, $r=\frac{5 \sqrt{2}}{2} \mathrm{~cm}$.

Figura 65 - Matemática na medida certa 9 - p. 139

O último capítulo sobre geometria desempenha a função de relembrar os conceitos de área de diversas formas geométricas e volume de prismas regulares. Como nos livros anteriores, os capítulos que abordam esse conteúdo não utilizam construção geométrica.

Mesmo sendo o livro com o maior número de páginas (e capítulos) sobre geometria, é o livro que menos aborda o conteúdo de construção geométrica, pois os conceitos geométricos abordados são utilizados de forma algébrica, sem necessidade de desenhos por parte do aluno.

A coleção como um todo não aborda de forma gratificante o conteúdo de construção geométrica. Os livros do $6^{\circ}$ e $9^{\circ}$ ano praticamente não possuem nada sobre o assunto, deixando apenas para os outros dois. Diversos tópicos da área não são abordados, sendo alguns básicos, como construção de retas paralelas com régua e compasso, e não com esquadro como abordado nos livros. 


\begin{tabular}{|l|l|}
\hline Conteúdo & Ferramentas \\
\hline Bissetriz e incentro & Régua e compasso \\
\hline Circunferência & Compasso \\
\hline Mediatriz & Régua e compasso \\
\hline Quadrilátero & Régua e esquadro \\
\hline Polígonos regulares & Régua, compasso e transferidor \\
\hline Retas paralelas & Régua e esquadro \\
\hline Triângulo & Régua e compasso \\
\hline
\end{tabular}

Quadro 4 - Conteúdos de construção geométrica Matemática na medida certa

\subsection{Nelson Mathematics}

A terceira coleção analisada (e primeira canadense) é chamada Nelson Mathematics, da editora Thomson Nelson. Os livros são um trabalho coletivo de vários autores canadenses, com Marian Small e Mary Lou Kestell, como autoras seniores. Os livros didáticos das autoras são utilizados na Áustria e Estados Unidos, além do próprio Canadá.

Os livros da coleção estão listados na Trillium List, aprovando-os assim para a utilização em toda Ontário. As edições analisadas datam de 2005 (mesma edição aprovada para uso) e estão na língua inglesa. Diferente das duas coleções brasileiras, a Nelson Mathematics possui livros de capa dura, material mais duradouro. As dimensões são de, aproximadamente, $25 \mathrm{~cm}$ de altura e $19 \mathrm{~cm}$ de comprimento. A espessura varia entre $2 \mathrm{~cm}$ e $2,5 \mathrm{~cm}$.

As capas são semelhantes (com exceção de um livro), de cor azul e com imagem de figuras que enaltecem a cultura canadense, como animais polares, neve e esportes de inverno. 


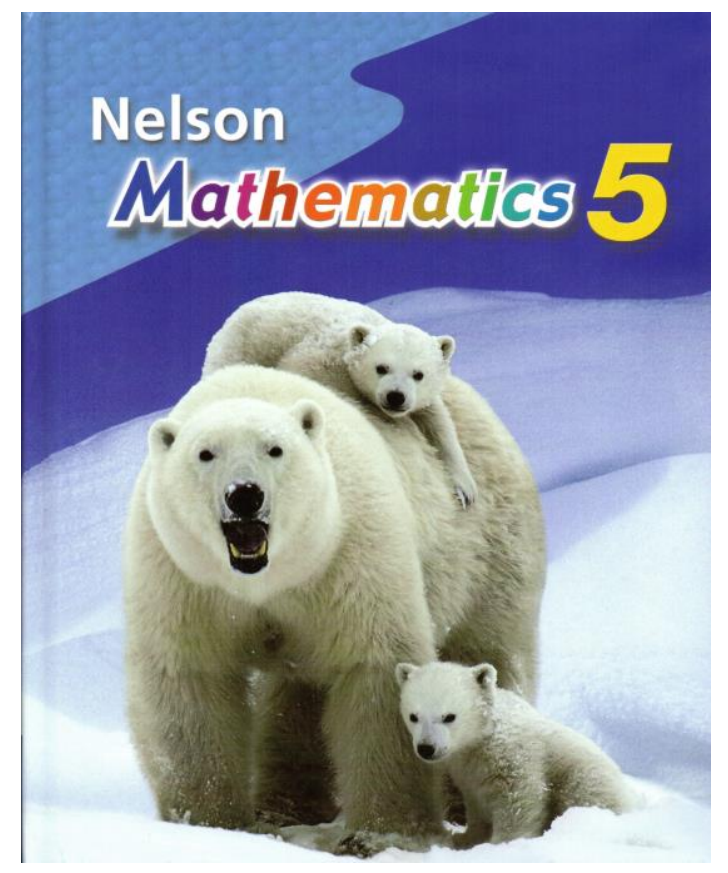

Figura 66 - Nelson Mathematics 5 - capa

O material utilizado nas páginas é de boa qualidade, tornando excelente a impressão de imagens coloridas. A fonte da letra se mantém a mesma por toda a obra, alterando apenas seu tamanho, quando necessário. As páginas são bem coloridas, com demarcações para separar os diversos tipos de atividades, exemplos ou textos teóricos.

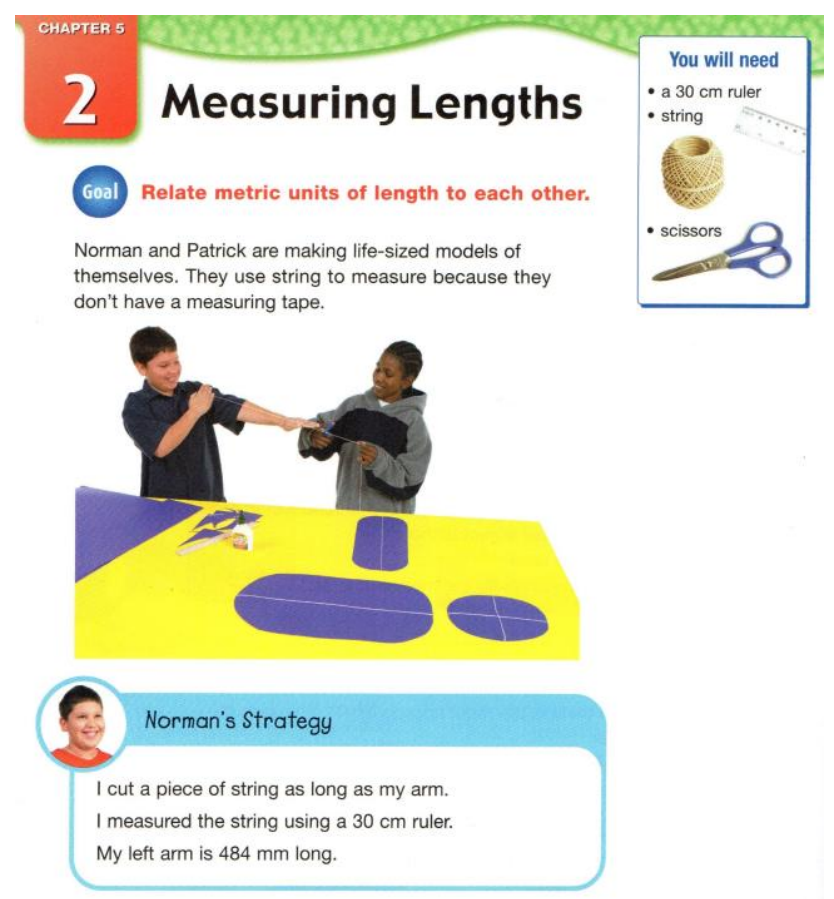

Figura 67 - Nelson Mathematics 5 - p. 130 
Cada capítulo se inicia com alguma imagem que remete ao conteúdo abordado, além de uma lista de objetivos para os alunos. Na sequência, temos uma seção intitulada Getting Started, na qual é realizada uma revisão de alguns conteúdos necessários para que o aluno tenha um aproveitamento adequado. Os capítulos são divididos em assuntos, chamados Lessons, e em cada assunto é apresentado o objetivo e materiais necessários.

Ao término de cada capítulo, encontram-se listas de exercício (Skills Bank, Problem Bank e Chapter Review, na tradução livre, Testes de habilidades, testes contextualizados e revisão do capítulo ${ }^{32}$ ), além de uma tarefa com tema relacionado ao capítulo. Em cada uma das listas os exercícios são separados de acordo com o assunto (ou Lesson).

Os livros possuem poucos paratextos anteriores ao conteúdo, contendo apenas ficha técnica e sumário (com dez páginas). Ao término do livro temos um glossário ilustrado e um índice remissivo, o que auxilia os alunos a encontrar termos matemáticos ao longo do texto, e finaliza com uma lista de créditos, com a lista de copyrights utilizados ao longo da obra.

\subsubsection{Nelson Mathematics 5}

O primeiro livro da coleção possui 448 páginas, divididas em 14 capítulos e alguns paratextos. A capa traz a imagem de ursos polares, animais encontrados em alguns territórios do Canadá. Cinco capítulos são separados para o estudo da geometria, totalizando em 148 páginas sobre o assunto.

A geometria é abordada no quinto capítulo, intitulado Measuring length and time (em tradução livre, medindo comprimento e tempo). No início temos a imagem de uma garota medindo o chão de uma quadra de basquete e os objetivos para o capítulo. Na página seguinte temos a seção Getting started, com uma revisão do conteúdo, em forma de exercícios.

Durante o capítulo, é solicitado aos alunos que utilizem régua, barbante e malha quadriculada para realizar as medidas, inserindo de forma atrativa a elaboração de figuras geométricas.

${ }^{32}$ A tradução realizada condiz com o conteúdo da seção, não apenas uma tradução do termo. 
O capítulo 7, segundo capítulo referente ao conteúdo de geometria, tem como título 2-D Geometry (Geometria 2-D). Dentre os objetivos do capítulo, observa-se a construção de ângulos e triângulos, conteúdos conhecidos por utilizarem objetos de construção geométrica.

Na segunda seção do capítulo temos a elaboração de triângulos, informando um lado e dois ângulos. Para isso, os alunos utilizam régua e transferidor. O passo a passo é demonstrado com imagens no livro, com uma seção de reflexão e prática sobre o conteúdo.

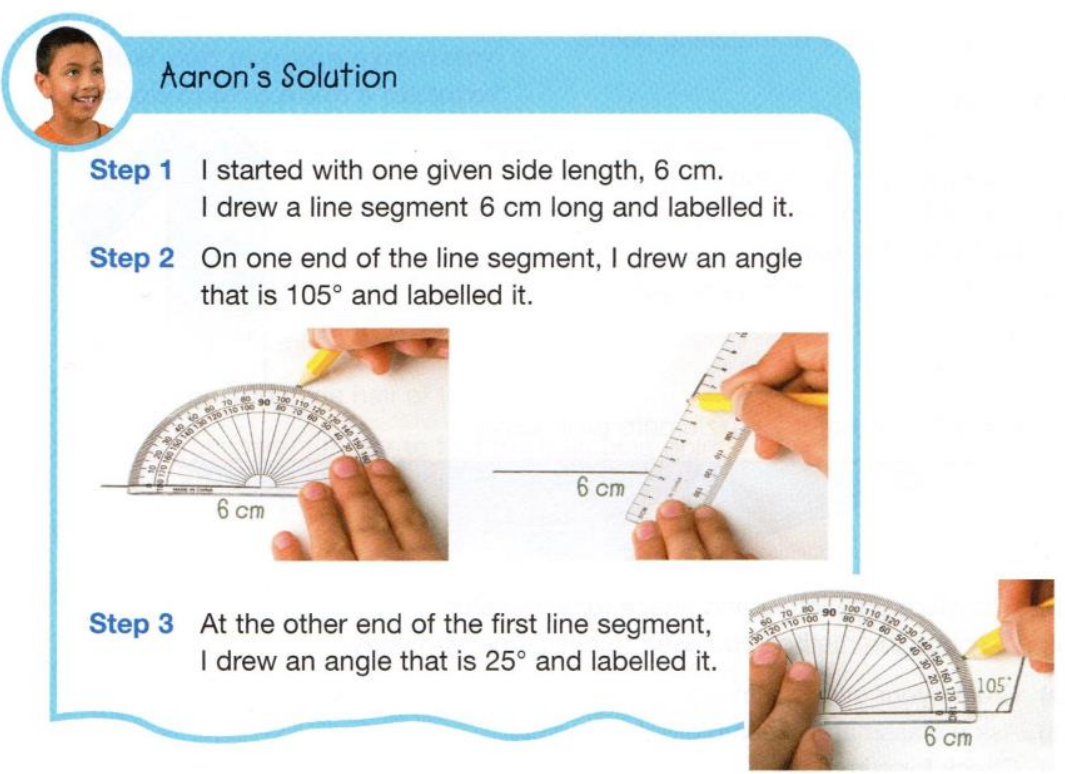

Figura 68 - Nelson Mathematics 5 - p. 192

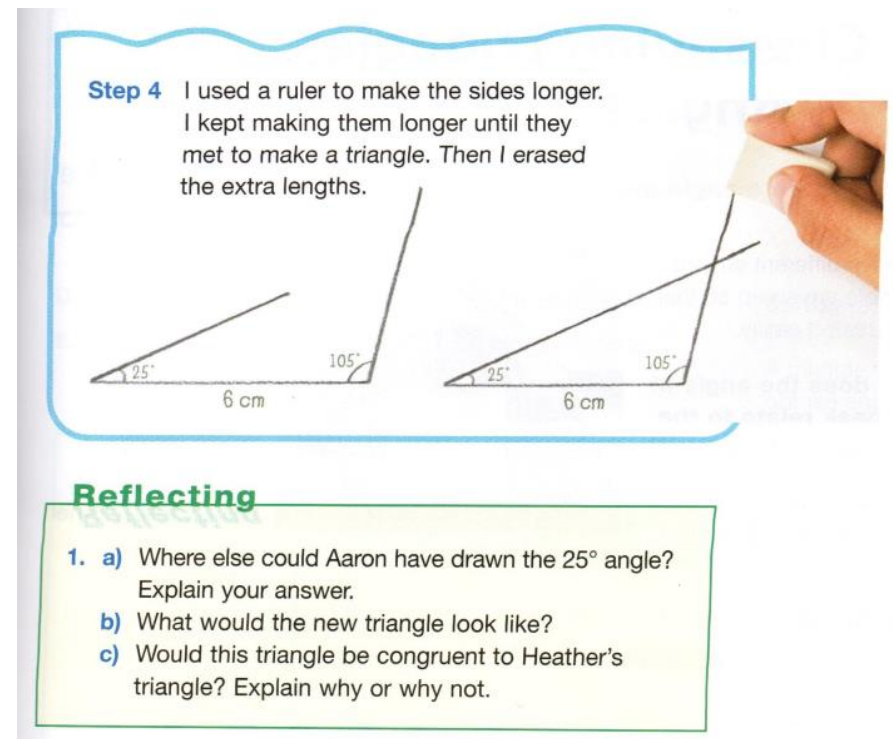

Figura 69 - Nelson Mathematics 5 - p. 193 
Esse modelo de criação de triângulos não utiliza compasso, mas serve para introduzir a utilização dos objetos geométricos necessários (sempre informados no início do capítulo, na parte superior direita). O restante do capítulo envolve classificação de triângulos e propriedades de polígonos, assunto que não compreende o tema pesquisado.

Encontramos o tema geometria nos capítulos 8 e 11 (capítulo 8: Area and grid e capítulo 11: 3-D Geometry and 3-D Measurement, em tradução livre: área e quadriculado e geometria e medição 3-D), que não aborda construção geométrica, portanto não será analisado.

O último capítulo do livro, Patterns and motion in Geometry, em tradução livre Padrões e movimento na geometria, traz a utilização de transferidor e alguns exemplos citando softwares de geometria, como na imagem abaixo.

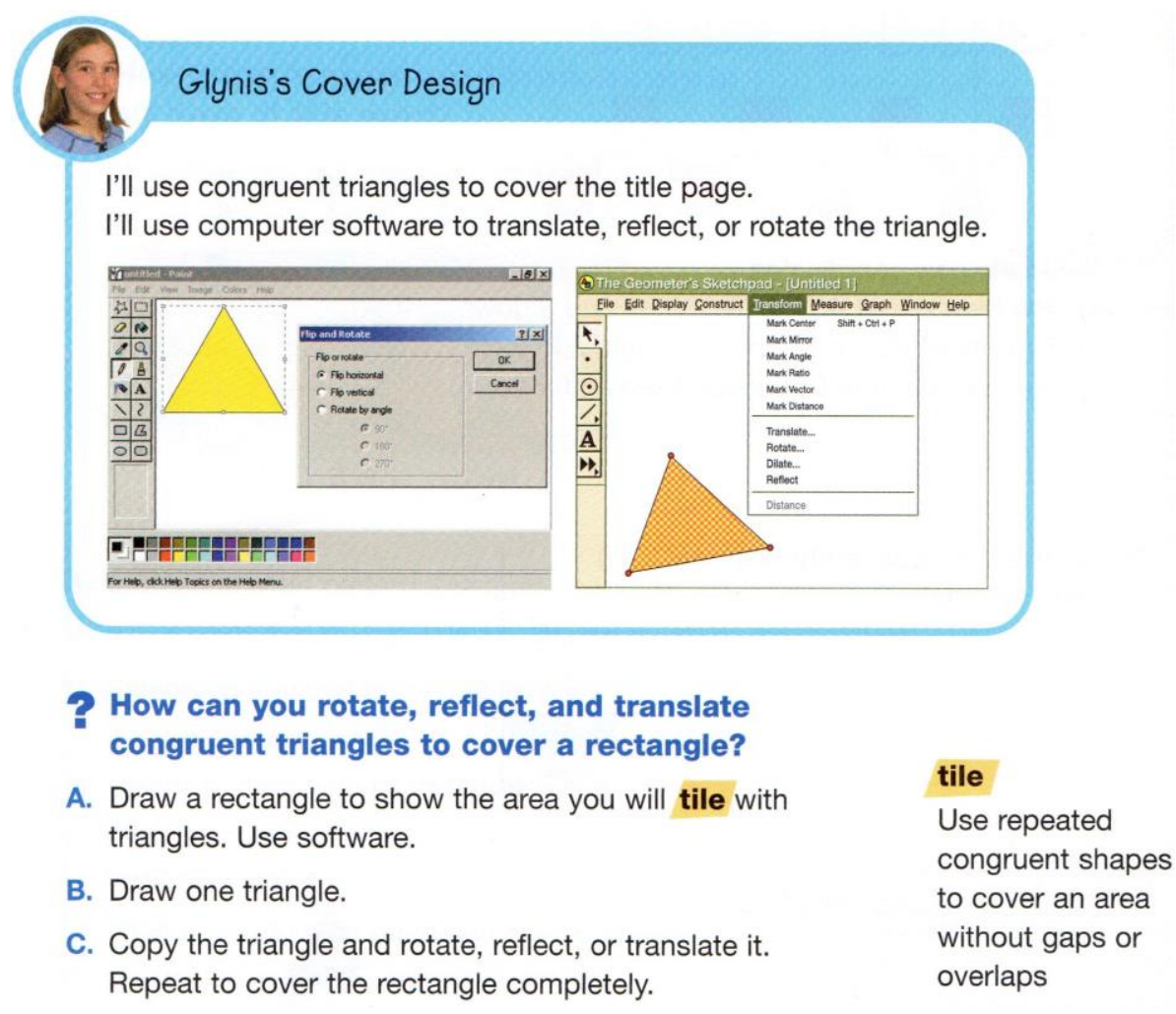

Figura 70 - Nelson Mathematics 5 - p. 384

O software apresentado é o The geometer's sketchpad, e será visto mais algumas vezes ao longo da coleção. Nota-se que a versão apresentada no livro é mais antiga, já que a coleção data de 2005. Na imagem vemos a opção de transformação, na qual é possível realizar diversas ações com a figura dada. 
No capítulo é mencionado a utilização do software, mas apenas como opcional.

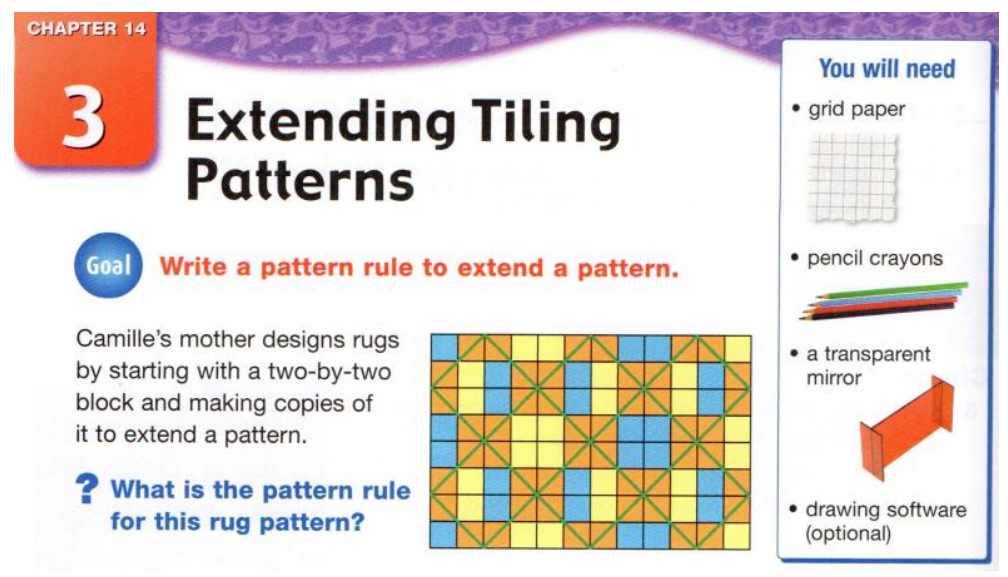

Figura 71 - Nelson Mathematics 5 - p. 388

O transferidor é usado na quinta seção do capítulo apenas para rotacionar objetos, logo, não é necessário construir os ângulos de rotação, tornando desnecessária a utilização de construção geométrica.

O primeiro livro da coleção não aborda de forma aprofundada a utilização de construção geométrica, mas trabalha com o uso de algumas ferramentas, além da utilização de softwares geométricos. Os próximos livros ampliam tais conhecimentos e acrescentam algumas construções geométricas.

\subsubsection{Nelson Mathematics 6}

O segundo livro da coleção possui 493 páginas, dividida em 14 capítulos e diversos paratextos. Cinco capítulos abordam o tema geometria, totalizando em 144 páginas. A palheta de cores é semelhante, com o acréscimo de alguns detalhes em amarelo na capa. A imagem apresentada também remete ao Canadá, a mesma trata-se de uma coruja em um ambiente nevado. O material usado na impressão do livro continua o mesmo, de excelente qualidade.

É no quinto capítulo que a geometria é abordada, "Measuring Length", em tradução livre: Medindo comprimento. No capítulo observamos a utilização de régua e folha quadriculada diversas vezes, mas não foi abordado o assunto de construção geométrica. A ausência de construção geométrica não é estranha, já que o objetivo do capítulo é medir objetos, e não os construir. Porém, ao abordar assuntos como 
perímetro de polígonos, é possível que se inicie a construção dos mesmos, mas os autores preferiram deixar para outra ocasião.

\section{Checking}

3. a) Measure the perimeter of the triangle shown.

b) Draw another shape with the same perimeter.

\section{Practising}

4. a) Measure the perimeter of each polygon.

i)

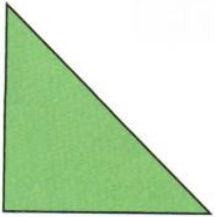

ii)

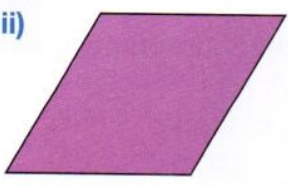

Draw a polygon with the same perimeter as the octagon

5. Draw two other shapes with the same perimeter as the parallelogram in Question 4.

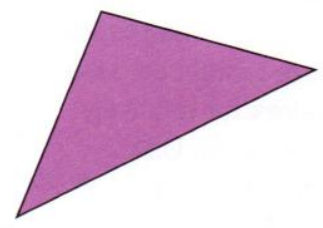

iii)

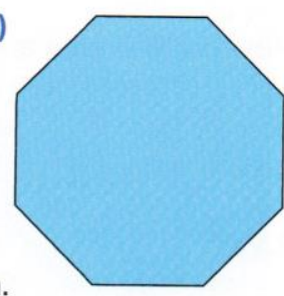

icing

Figura 72 - Nelson Mathematics 6 - p. 147

Nos exercícios 4 e 5 é solicitada a construção de polígonos, mas sem deixar claro a necessidade de algum objeto geométrico, deixando a cargo do aluno quais ferramentas usar, dando espaço para criatividade e entendimento dos conceitos de construção geométrica.

O segundo capítulo sobre geometria é o sétimo do livro: 2-D Geometry, ou Geometria 2-D. Durante a primeira seção do capítulo, Estimating angle measures, em tradução livre: Estimando medidas de ângulos, observa-se um exemplo interessante. 


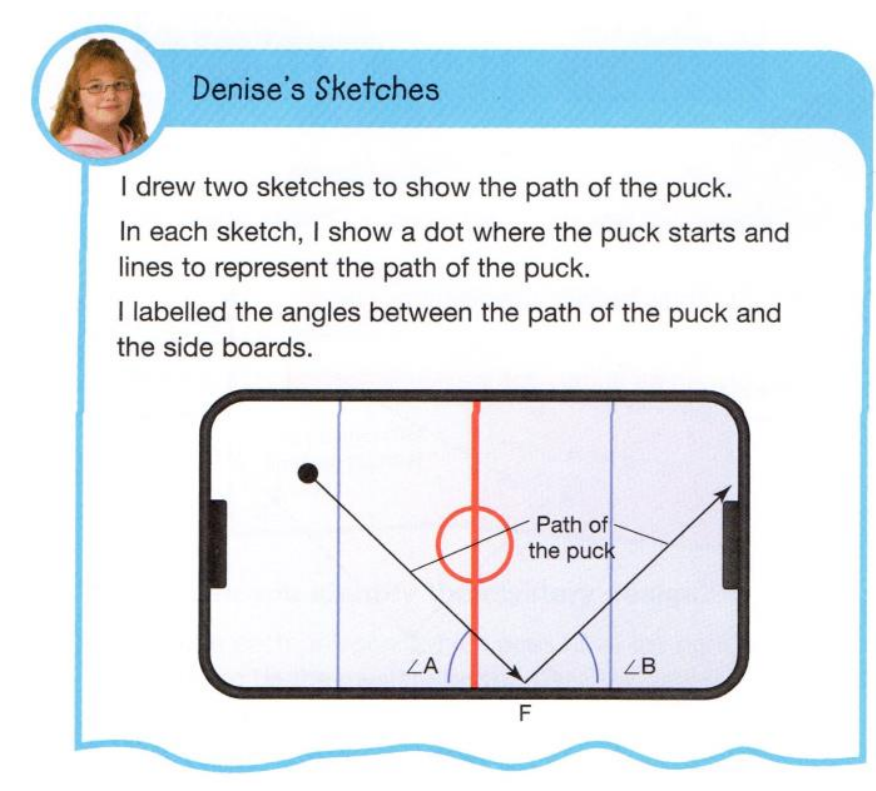

Figura 73 - Nelson Mathematics 6 - p. 210

Tradução: Eu desenhei dois esboços para mostrar o caminho do disco.

Em cada um, mostro um ponto onde o disco começa e linhas para representar o caminho do disco.

Eu rotulei os ângulos entre o caminho do disco e as placas laterais.

$\mathrm{Na}$ imagem é possível perceber que, para introduzir o tema, o autor usa um exemplo de air hockey, jogo pouco conhecido no Brasil. A escolha de um exemplo simples para todos os alunos é fundamental na construção de um conceito matemático, entretanto, no Brasil, o exemplo citado no livro não teria o mesmo impacto.

A terceira seção do capítulo aborda alguns assuntos interessantes, como a condição de existência de um triângulo e o uso da palavra hipótese. 
Emilio measured some triangles and noticed something true

When I add the lengths of two sides of a triangle, the sum is always greater than the other length.

I think this is always true.

I'll test my hypothesis with more examples.
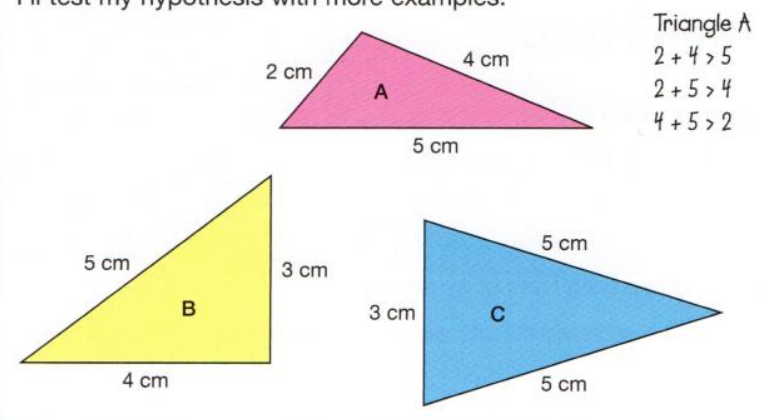

A. Did Emilio state his hypothesis clearly?

B. Did Emilio communicate his hypothesis and his reasons using mathematical language?

C. Was it clear how Emilio would choose examples to test his hypothesis?

D. How can you improve Emilio's communication?

Communication Checklist

$\checkmark$ Did you use math language?

$\square$ Did you explain your thinking?

$\checkmark$ Did you include diagrams?

Figura 74 - Nelson Mathematics 6 - p. 214

A condição de existência de um triângulo é abordada na forma de exemplo, e os autores aproveitam o momento para apresentar a palavra hipótese. Além do exemplo, uma lista de perguntas reflexivas auxilia os alunos a compreenderem tanto o conteúdo matemático como o uso da palavra.

Construir polígonos é o nome dado para a quarta seção do capítulo (no original, Constructing polygons), mas ao invés de compasso, utiliza-se transferidor. Por meio de um exemplo é introduzida a construção de um paralelogramo com dimensões e ângulos predefinidos e os autores aproveitam a ocasião para inserirem $o$ assunto escala. 
The set designer gave me this incomplete sketch of a parallelogram.

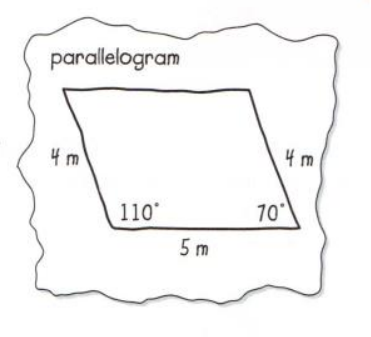

My paper is not big enough for me to draw a diagram with side lengths in metres.

I'll draw with a scale of $1 \mathrm{~cm}$ represents $1 \mathrm{~m}$. Then I can draw in centimetres instead of metres. I start by drawing and labelling the $5 \mathrm{~cm}$ side.

Then I construct the $110^{\circ}$ angle at one end of the side. $110^{\circ}$ is $20^{\circ}$ past the $90^{\circ}$ angle mark.

Figura 75 - Nelson Mathematics 6 - p. 218

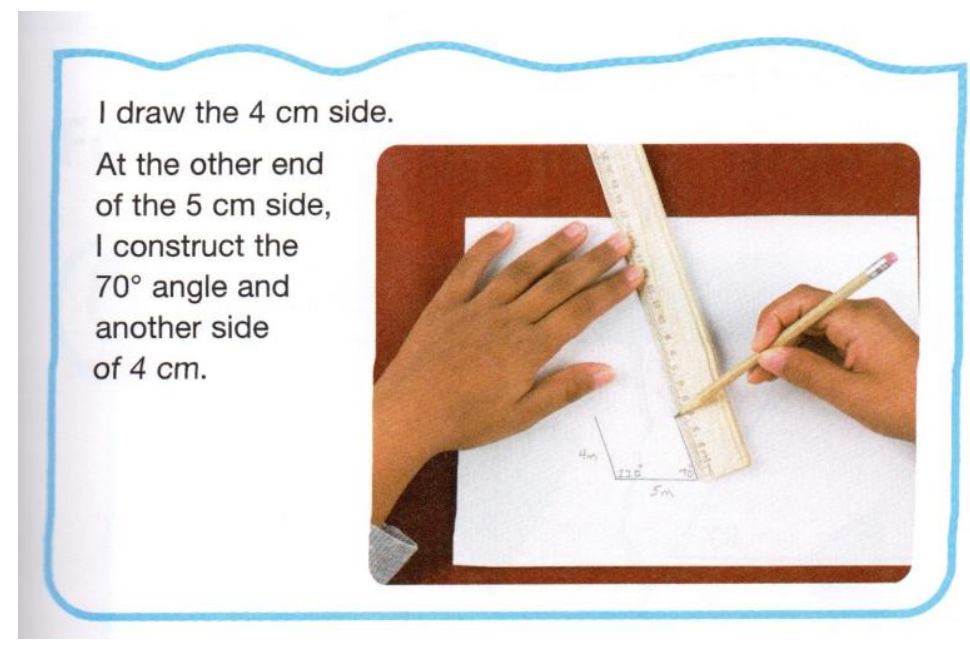

Figura 76 - Nelson Mathematics 6 - p. 219

Durante a seção, os autores acrescentam alguns exercícios para a prática do método aprendido, mas sem a utilização de compasso. 


\section{Practising}

4. Draw these polygons.

a) parallelogram

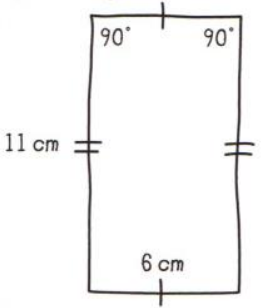

b) parallelogram

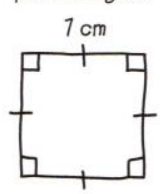

c) regular pentagon

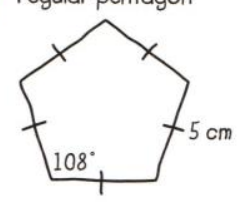

5. Draw a rhombus with side lengths of $10 \mathrm{~cm}$ and angle measures of $40^{\circ}$ and $140^{\circ}$

6. The measurements of the sides and angles in this parallelogram are all correct, but the set designer put some of the labels in the wrong places.

a) What possible errors were made in this sketch? Explain.

b) Draw a scale diagram of the parallelogram.

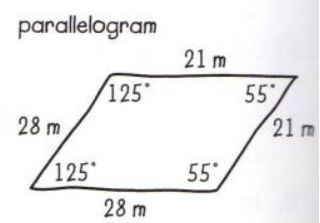

Figura 77 - Nelson Mathematics 6 - p. 220

Os capítulos 7, 11 e 14 (2-D Geometry, 3-D Geometry and 3-D measurement e Patterns and Motion in Geometry, respectivamente, em tradução livre: Geometria 2-D, Geometria e medição 3-D e Padrões e movimento na geometria), abordam assuntos nos quais não é utilizada a construção geométrica. Com isso, conclui-se a análise do livro do sexto ano.

Repete-se o que ocorreu no livro anterior: pouca utilização de construção geométrica, mesmo abordando alguns assuntos em que seria possível aplicar esse conhecimento. Para os dois últimos livros da coleção se espera maior aprofundamento em alguns conceitos, como na construção de polígonos.

\subsubsection{Nelson Mathematics 7}

O terceiro livro analisado da coleção possui 523 páginas, dividido em 12 capítulos e com diversos paratextos. A arte da capa mantém o vínculo com o Canadá, dessa vez trazendo uma pessoa praticando snowboard. A palheta de cores se mantém. Entre os 12 capítulos, 4 abordam o tema geometria, totalizando 142 páginas sobre 0 assunto.

O primeiro capítulo sobre geometria se chama 2-D Measurement, em tradução livre, Medição 2-D. Nele, os autores abordam os cálculos de área de diversos polígonos, inclusive recapitulando algumas formas já estudadas, como 
paralelogramo. Para apresentar os polígonos, são usadas folhas quadriculadas e o GEOBOARD ${ }^{33}$. Os alunos não precisam, nesse ponto, construir os polígonos com régua e compasso.

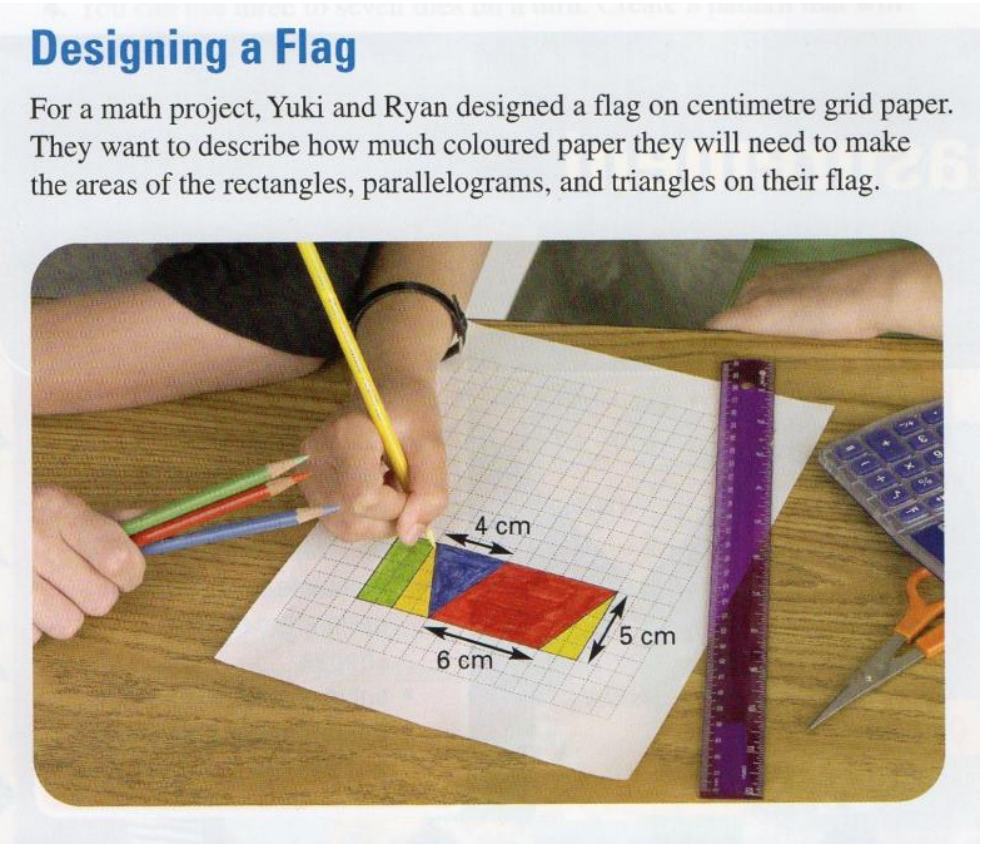

Figura 78 - Nelson Mathematics 7 - p. 150

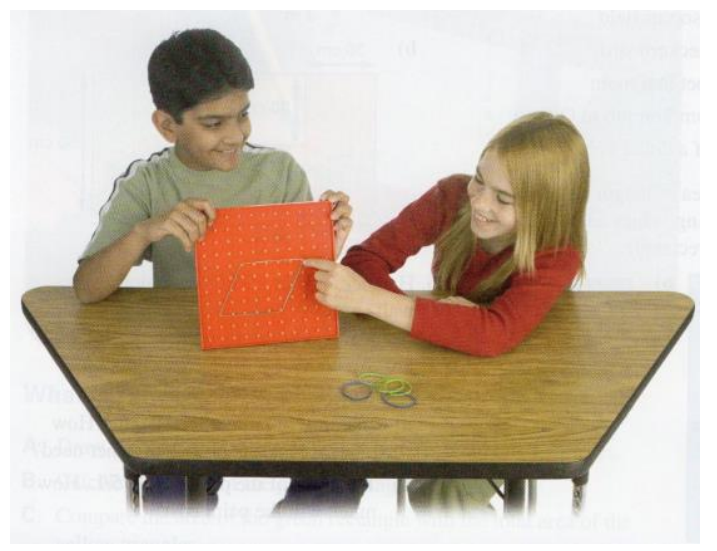

Figura 79 - Nelson Mathematics 7 - p. 152

No capítulo 2-D Geometry, em tradução livre, Geometria 2-D, temos abordados os assuntos de transformação, como translação, reflexão e rotação. Para trabalhar esses conceitos, os autores utilizam o papel quadriculado, um plano cartesiano e régua. Mesmo com ferramentas não tradicionais, os alunos fazem

33 Geoboard, em português geoplano. O geoplano é uma ferramenta formada por uma placa de madeira onde são cravados pregos, formando uma malha composta por linhas e colunas. Seu uso é recomendado em situações de cálculo de área, perímetro, figuras simétricas, arestas, vértices e construção de polígonos. 
esboços de polígonos com o auxílio do papel quadriculado, contribuindo para a compreensão de conceitos geométricos.

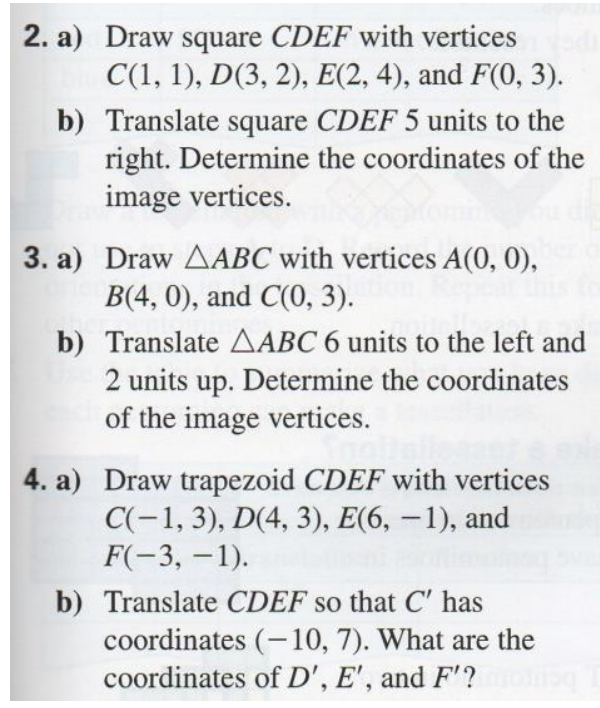

Figura 80 - Nelson Mathematics 7 - p. 247

Nos exercícios acima observamos a construção de três polígonos distintos, todos com vértices informados para elaboração em plano cartesiano. Os alunos não utilizam compasso e nem etapas conhecidas na construção geométrica tradicional, mas utilizam certas ferramentas para elaborar as figuras geométricas desejadas, portanto houve construção e utilização de alguns conceitos geométricos.

Os dois últimos capítulos que abordam geometria também não trazem nenhum uso para a construção geométrica, deixando, assim, esse livro como o primeiro analisado sem nenhuma aproximação real com a construção geométrica tradicional.

\subsubsection{Nelson Mathematics 8}

O último livro da coleção conta com 12 capítulos, distribuídos em 528 páginas, incluindo alguns paratextos. Encontramos geometria em 4 desses capítulos, totalizando em 124 páginas sobre o assunto. A imagem da capa destoa das demais, trata-se de um goleiro de futebol, esporte conhecido mundialmente, e praticado de forma mais habitual no verão.

O capítulo 5 é o primeiro que aborda o assunto geometria, e traz como tema círculos e circunferências. Nota-se que durante toda a obra esse é o primeiro 
capítulo focado no estudo dessas formas geométricas. Na primeira seção do capítulo, observamos a criação de um triângulo através de um círculo, mas não é dado ênfase na construção do círculo em si.

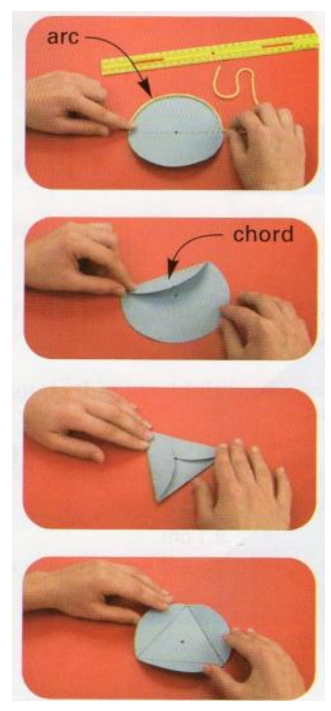

Figura 81 - Nelson Mathematics 8 - p. 152

Em relação aos exercícios, poucos são vistos. Na grande maioria são apenas para calcular área ou comprimento. Da lista abaixo, de oito exercícios, apenas um pede a construção da figura.

Round your answers to the same number of decimal places as in the given measurements.

\section{A Checking}

4. Calculate the circumference of a circle with each diameter. Use the formula $C=\pi d$.
a) $5 \mathrm{~cm}$
b) $4.7 \mathrm{~cm}$

5. Calculate the circumference of a circle with each radius.
a) $10 \mathrm{~cm}$
b) $8.2 \mathrm{~m}$

\section{B Practising}

6. Calculate the circumference of a circle with each diameter.
a) $4.5 \mathrm{~cm}$
d) $36.0 \mathrm{~m}$
b) $1.7 \mathrm{~cm}$
e) $7 \mathrm{~mm}$
c) $6.4 \mathrm{~cm}$
f) $4.0 \mathrm{~cm}$

7. Calculate the circumference of a circle with each radius.
a) $7 \mathrm{~mm}$
d) $9.0 \mathrm{~cm}$
b) $19.5 \mathrm{~cm}$
e) $23.1 \mathrm{~m}$
c) $6.3 \mathrm{~cm}$
f) $0.05 \mathrm{~m}$

8. The diameter of the wheels on Xavier's bicycle is $80 \mathrm{~cm}$. Calculate the circumference of the wheels.

9. a) Draw a circle with a diameter of $11 \mathrm{~cm}$. Explain what you did.

b) What is the circumference of your circle?

10. At summer camp, Maria uses chalk to draw a meeting circle around a flagpole. The distance from one side of the circle, through the flagpole, to the other side is $11.0 \mathrm{~m}$. How long is the chalk line around the circle?

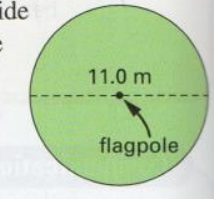

11. Copy and complete the chart.

\begin{tabular}{|l|c|c|c|}
\hline Item & \multicolumn{1}{c|}{$\boldsymbol{r}$} & \multicolumn{1}{c|}{$\boldsymbol{d}$} & $\boldsymbol{C}$ \\
\hline clock & $9.0 \mathrm{~cm}$ & & \\
\hline watch & & $36 \mathrm{~mm}$ & \\
\hline round tea bag & $1.9 \mathrm{~cm}$ & & \\
\hline sewer cover & & $62 \mathrm{~cm}$ & \\
\hline circle protractor & $5.9 \mathrm{~cm}$ & & \\
\hline electric fan & & $201 \mathrm{~mm}$ & \\
\hline
\end{tabular}

Figura 82 - Nelson Mathematics 8 - p. 158 
Neste capítulo, um breve resumo de como construir um círculo é observado, seguido de uma imagem. No início do capítulo tais etapas não são informadas.

Q: How can you use a compass to draw a circle if you know its radius or diameter?

A: If you know the radius, go to step 2.

1. If you know the diameter, divide it by 2 to determine the radius. For example, a circle with a diameter of $14.0 \mathrm{~cm}$ has a radius of $7.0 \mathrm{~cm}$.

2. Adjust the compass so that the distance between the compass point and the pencil tip is equal to the radius. Put the compass point where you want the centre of the circle to be. Then draw the circle.

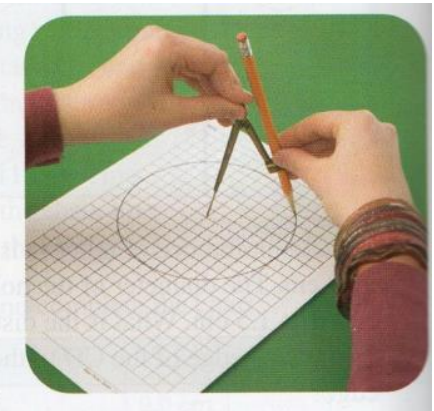

Q: How can you determine the circumference of a circle if you know its diameter?

A1: You can estimate. Since the circumference of a circle is about three times its diameter, you can multiply its diameter by 3 . For example, the circumference of a circle with a diameter of $6 \mathrm{~cm}$ is about $3 \times 6 \mathrm{~cm}$, or $18 \mathrm{~cm}$.

Figura 83 - Nelson Mathematics 8 - p. 160

Na quarta seção do capítulo, Estimating area, em tradução livre, Estimativa de área, temos a utilização de um CD para construir uma circunferência, contextualizando o conteúdo área de um círculo como um problema.
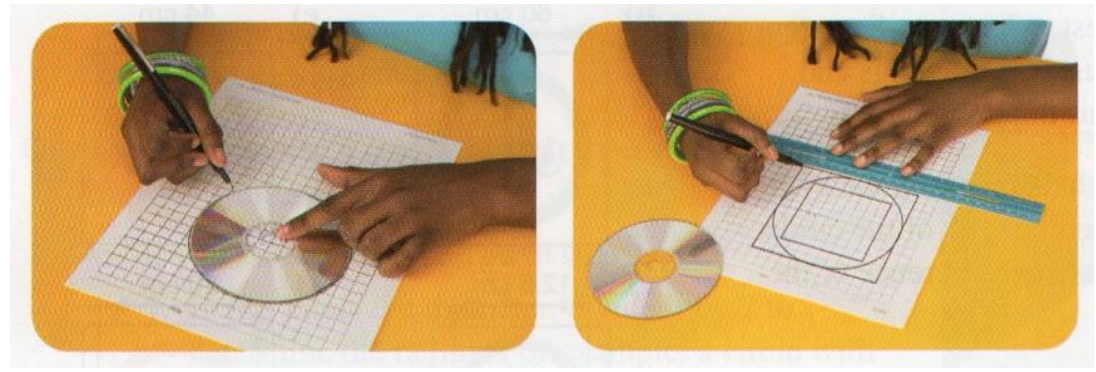

Figura 84 - Nelson Mathematics 8 - p. 162

A escolha de trazer uma contextualização para iniciar o conteúdo é interessante, ainda mais quando é acompanhado de um exercício, pois coloca o aluno no papel de protagonista, de responsável da descoberta. 


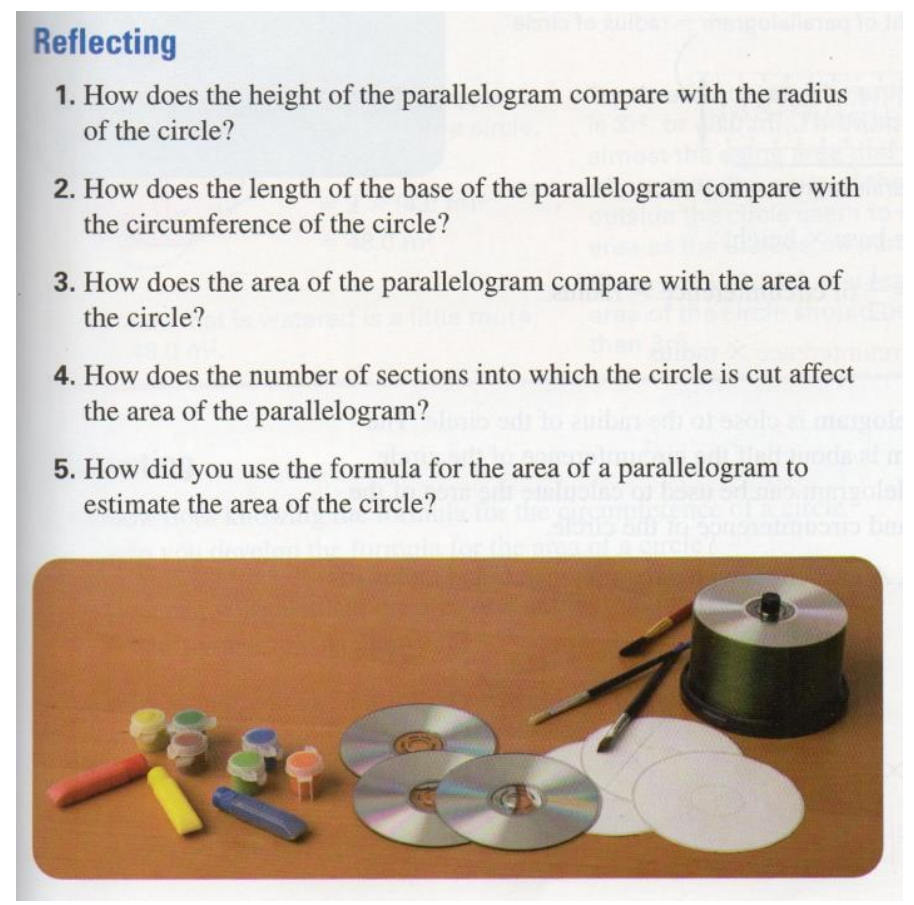

Figura 85 - Nelson Mathematics 8 - p. 163

Ao longo do capítulo vemos mais exercícios solicitando a construção de círculos e circunferências, mas em pouca quantidade, e sempre semelhantes.

No capítulo 7, Transformations, em tradução livre, Transformações, vemos um complemento do conteúdo abordado no livro anterior. Novamente, observamos a utilização do software Geometer's sketchpad, desta vez utilizado para transladar um triângulo. 


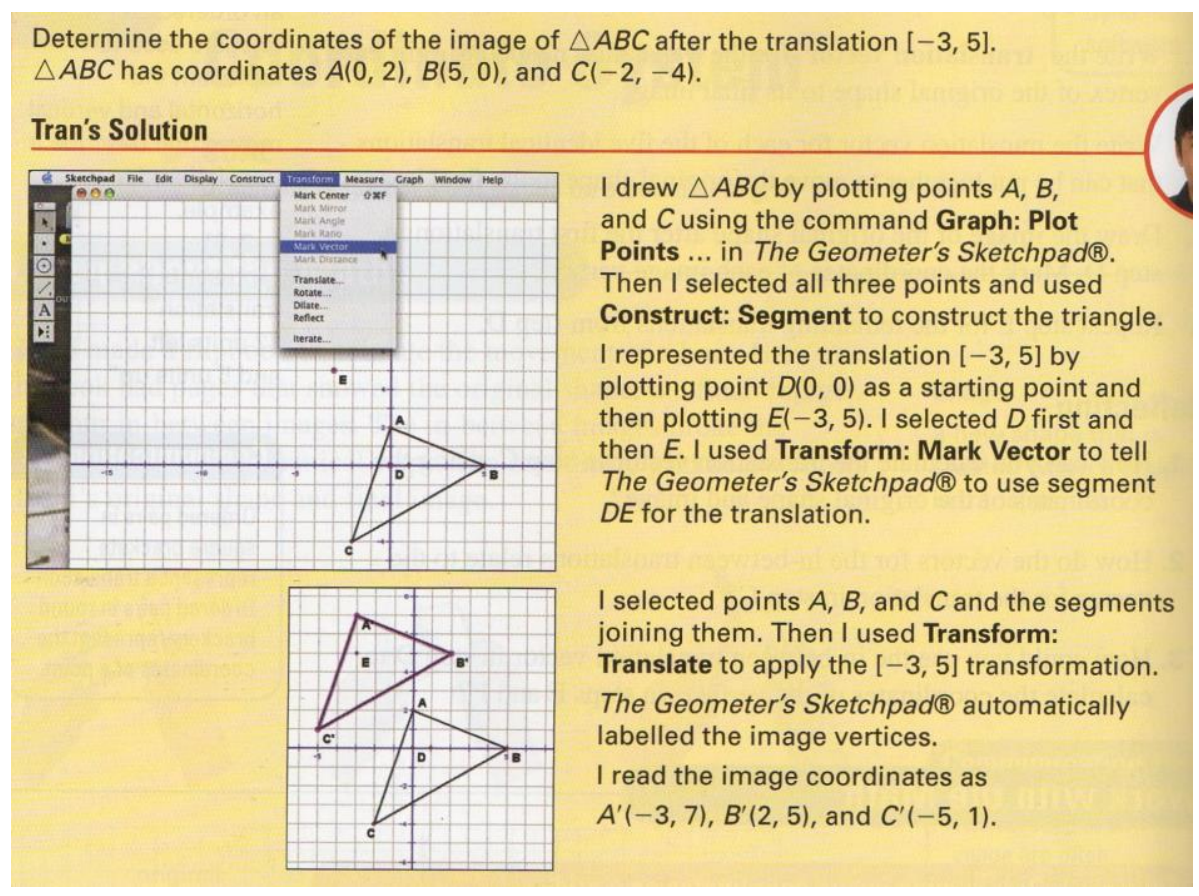

Figura 86 - Nelson Mathematics 8 - p. 228

O décimo capítulo da obra, Angles and triangles, em tradução livre, Ângulos e triângulos, se inicia com a utilização de compasso para encontrar a perpendicular em um exemplo contextualizado. Além de listar todas as etapas da realização do exercício, é utilizado imagens reais para auxiliar a compreensão do que é feito, como vemos abaixo.

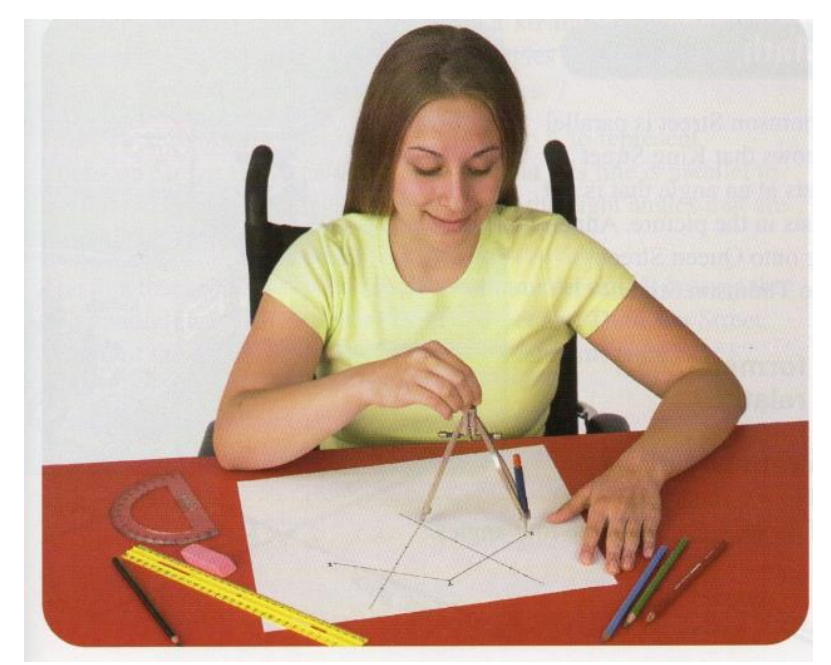

Figura 87 - Nelson Mathematics 8 - p. 339

Durante as primeiras seções do capítulo não vemos mais a utilização de ferramentas geométricas (com exceção da régua para construção de segmentos). As seções sobre triângulos e quadriláteros já apresentam as figuras, não 
dependendo do aluno para as suas construções. Na sequência do capítulo temos a aplicação do teorema de Pitágoras, tornando os exercícios mais algébricos, e sempre apresentando as imagens utilizadas.

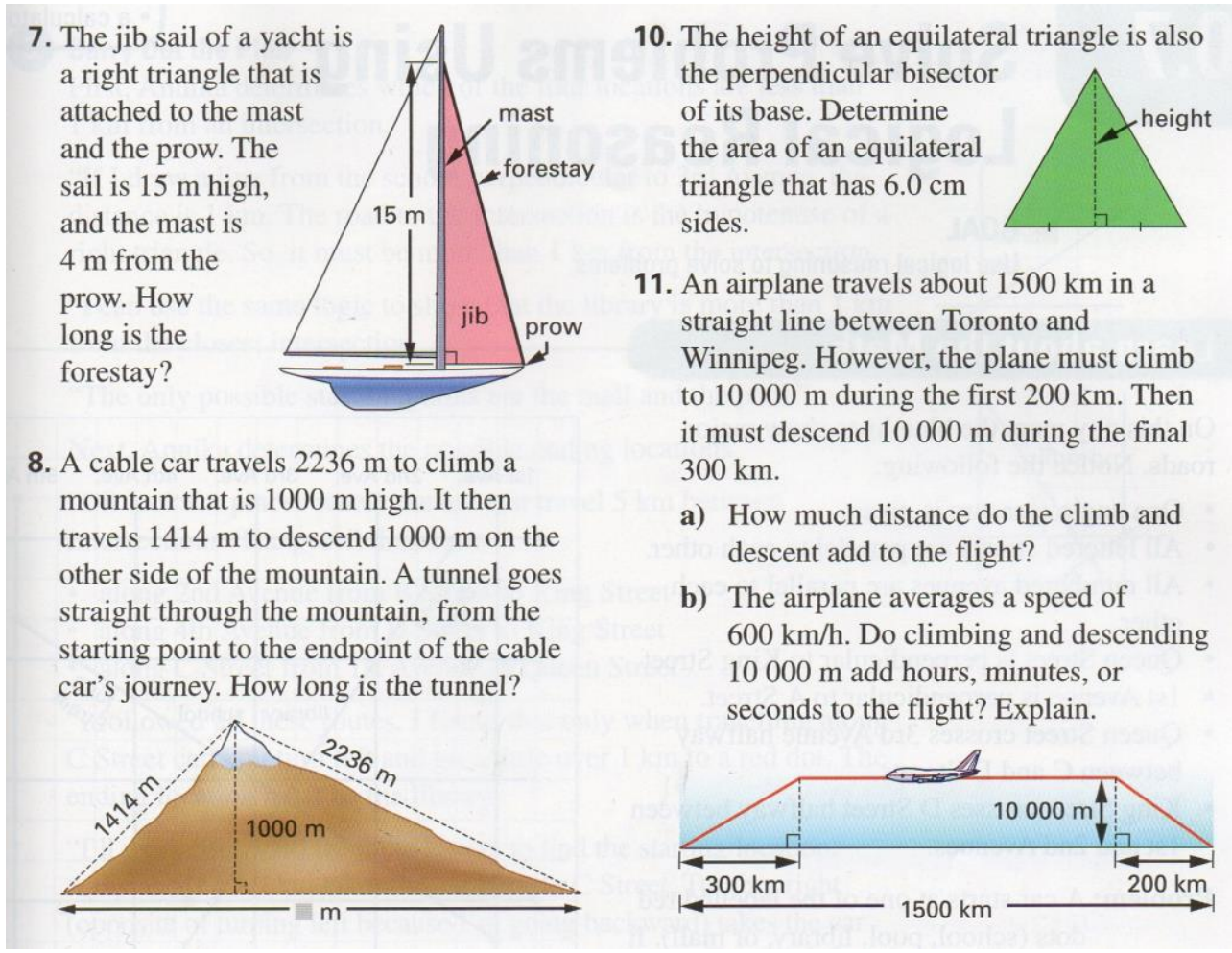

Figura 88 - Nelson Mathematics 8 - p. 357

O último capítulo sobre geometria chama-se Geometry and Measurement relationships, em tradução livre, Geometria e relações de medição, e aborda algumas construções simples, como segmentos de reta e circunferências, logo utiliza régua e compasso como ferramentas, mas não aprofundam a sua aplicação.

A obra Nelson Mathematics como um todo não aborda de forma incisiva a construção geométrica. Durante a coleção observamos algumas aplicações pontuais, mas sempre focando em apenas alguns exercícios, normalmente em seções separadas. Os alunos não precisam desenhar muitas figuras, pois os exercícios trazem todas as imagens necessárias para sua resolução. 


\begin{tabular}{|l|l|}
\hline Conteúdo & Ferramentas \\
\hline Circunferência & Compasso \\
\hline Paralelogramo & Régua, transferidor e geoboard \\
\hline Polígonos & Régua e transferidor \\
\hline Reta perpendicular & Régua e compasso \\
\hline Triângulo & Régua e transferidor \\
\hline
\end{tabular}

Quadro 5 - Conteúdos de construção geométrica Nelson Mathematics

\subsection{MATH MAKES SENSE}

A última coleção analisada (e segunda canadense) chama-se Math Makes Sense, da editora Person Addison Wesley e, diferentemente das demais, é uma obra com um coletivo de 12 autores no total. As edições analisadas datam de 2005, edição aprovada na Trillium list.

A editora Person publica coleções diferentes para cada região do Canadá, então deve-se lembrar que a coleção analisada foi criada e publicada para uso na província de Ontário, na qual o ensino fundamental básico possui 8 anos, e não 9 como em grande parte do Canadá.

Toda a obra foi adquirida em formato digital, pois não obtive acesso a elas em formato físico, portanto não será possível realizar uma pequena análise do material utilizado tanto nas capas como nas folhas internas e da impressão de imagens e fotos. As imagens das capas são todas voltadas à vida selvagem do Canadá, com fotos de diversos animais encontrados em seu vasto território (e muitos não comuns no Brasil). 


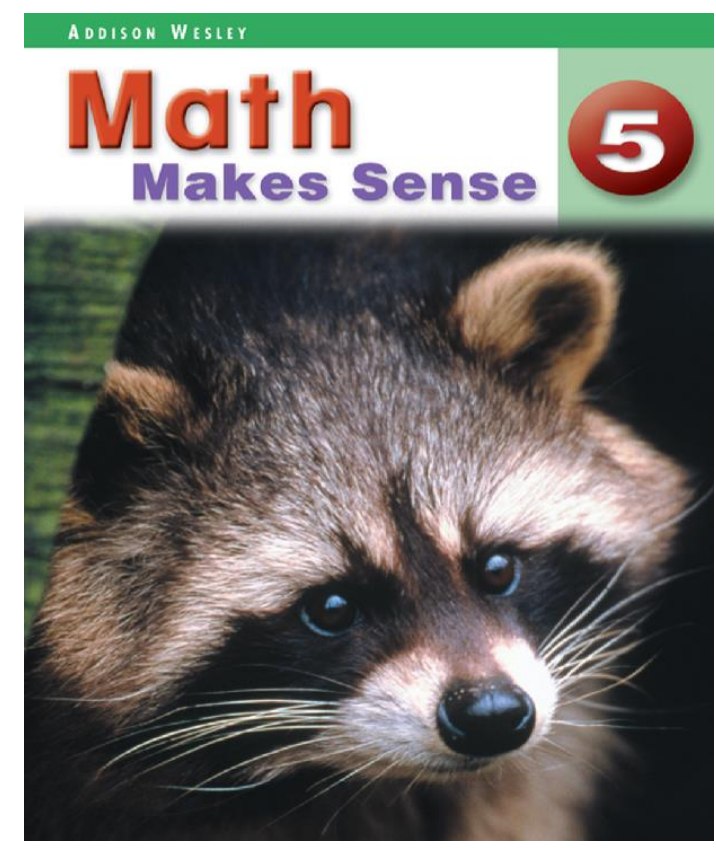

Figura 89 - Math makes sense 5 - capa

A utilização dos livros adquiridos é realizada pela própria página da editora, com acesso através de um login com senha. O uso é simples, com diversos atalhos, além de opções para marcação de página, pesquisa por palavras-chave, zoom nas imagens e anotações em qualquer local da página. Pelo fato da obra ser digital, o valor de compra é menor, economizando com material e envio.

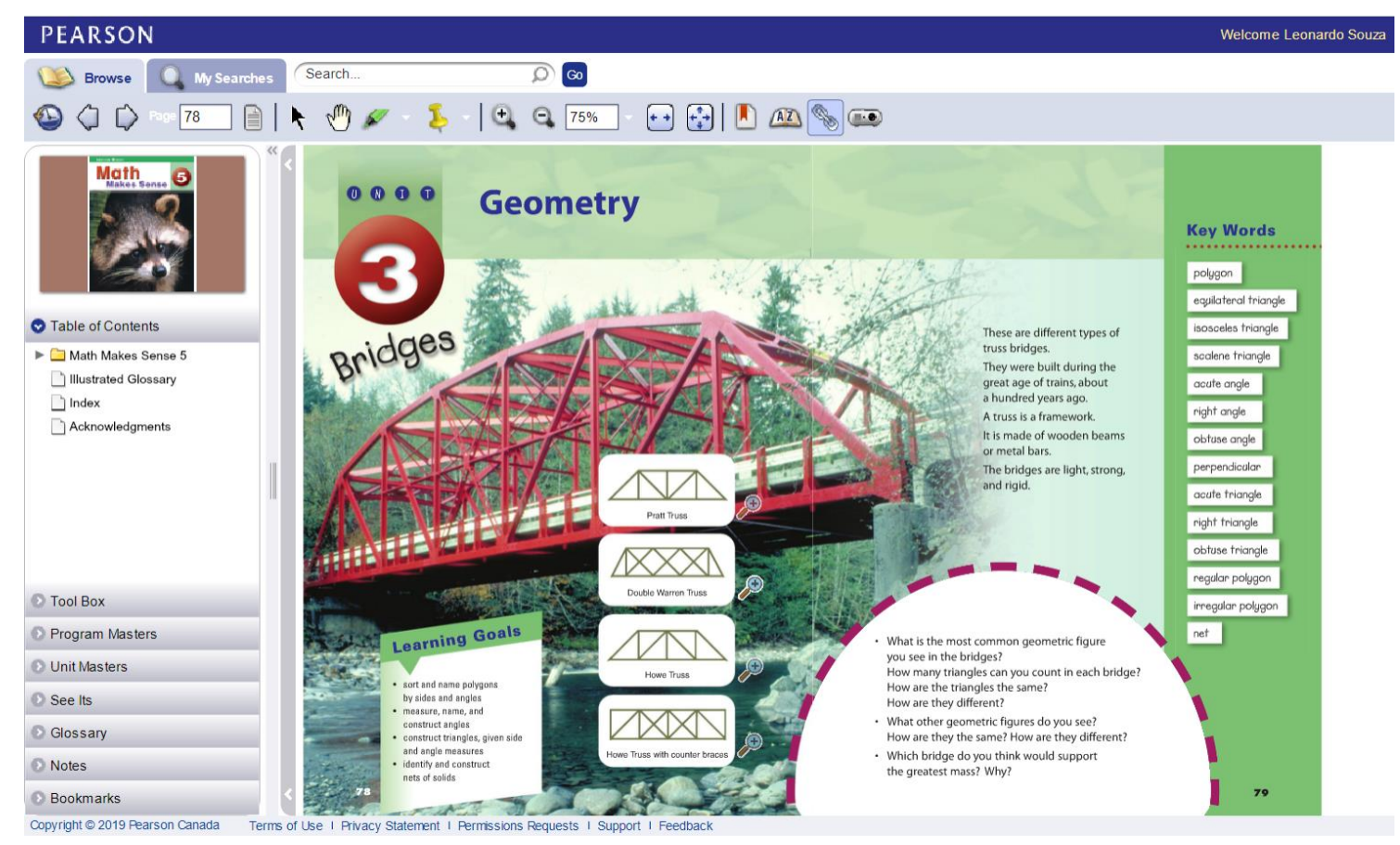

Figura 90 - Math makes sense - plataforma digital 
Todos os livros possuem um paratexto explicando todas as características da obra, como seções, ícones e paratextos encontrados ao longo dos capítulos. O início de cada capítulo conta com imagens que contextualizam o tema, além de uma lista de palavras-chave e objetivos de aprendizagem.

Ao término de cada unidade encontram-se listas extras de exercícios, jogos com aplicações dos temas apresentados, um problema mais elaborado chamado Unit problem, além de uma seção que instiga a investigação por parte do aluno. No final dos livros temos uma revisão cumulativa, glossário ilustrado e índice. Todas essas informações não são exclusivas da versão digital, estão também inclusas nas físicas.

\subsubsection{Math Makes Sense 5}

O primeiro livro da coleção conta com 433 páginas, distribuídas em 11 unidades e diversos paratextos. Ao todo, 3 unidades abordam o tema geometria, totalizando em 106 páginas sobre o tema. Na capa temos a imagem de um guaxinim, animal bem comum na América do Norte, trazendo, assim, características da sua cultura, algo também visto na coleção anterior.

A terceira unidade do livro é a primeira do tema geometria (sendo esse o nome da unidade, Geometry). Nas páginas de apresentação da unidade já observamos os temas trabalhados, como ângulos, triângulos e polígonos. Com tais temas é possível abordar alguns assuntos referentes à construção geométrica.

Seguindo o padrão da obra anterior, a construção de polígonos fica por conta do geoboard, enquanto as demais figuras já são apresentadas na obra, sem necessidade de o aluno desenhar. Na primeira seção são apresentadas apenas as classificações de triângulos. 


\section{Practice}

1. Use a geoboard, geobands, and dot paper.

a) Make 3 different scalene triangles. Record each triangle on dot paper. How do you know each triangle is scalene?

b) Make 3 different isosceles triangles. Record each triangle on dot paper. How do you know each triangle is isosceles?

c) Try to make an equilateral triangle. What do you notice?

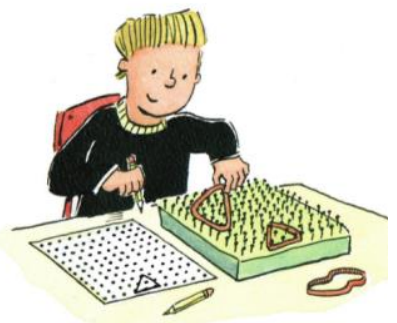

Figura 91 - Math makes sense 5 - p. 82

Na segunda seção é apresentada a construção de ângulos, mas não se utiliza compasso, e sim um transferidor. As etapas são apresentadas de forma clara, utilizando imagens. Vale ressaltar que, com o livro digital é possível aumentar as imagens, tornando-as ainda mais claras. As classificações de ângulos também são apresentadas. Até o momento não é utilizada nenhuma forma de construção geométrica com compasso.

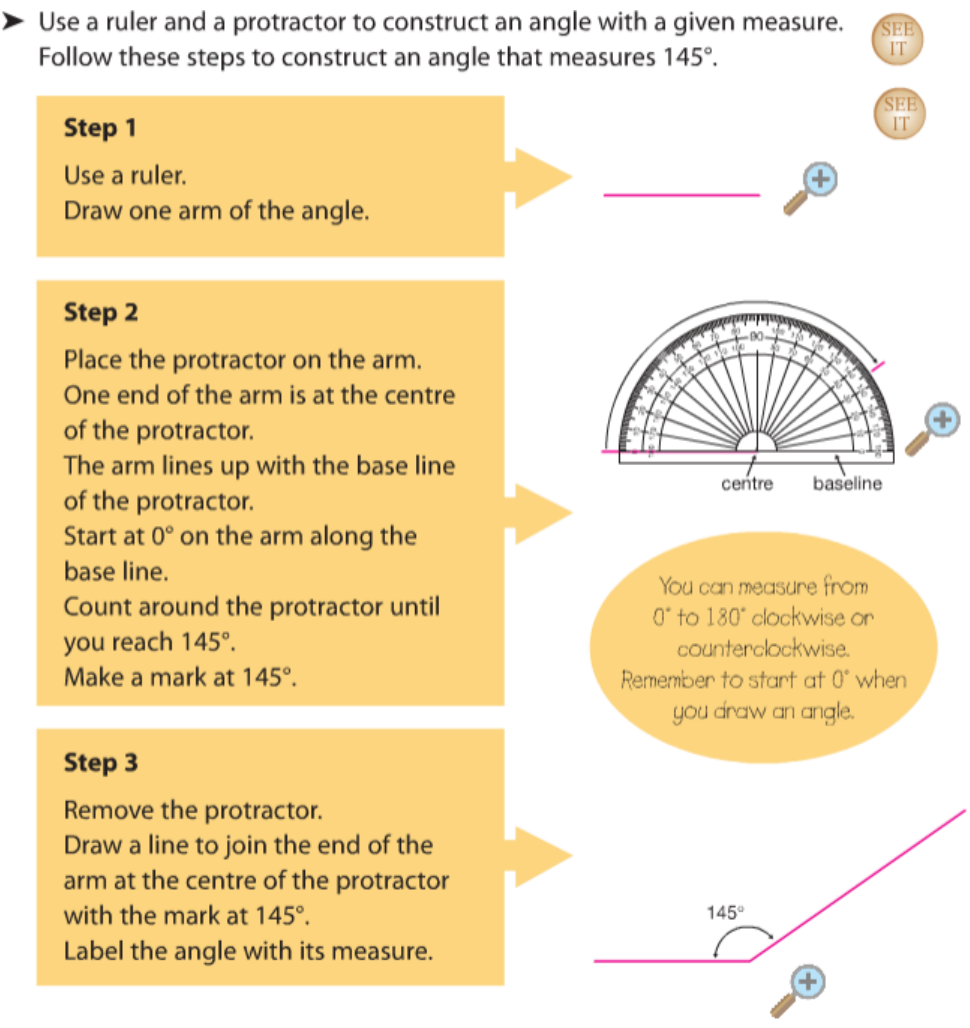

Figura 92 - Math makes sense 5 - p. 85

Na seção sobre polígonos, as construções também são realizadas com a utilização do geoboard, sem nenhuma menção a outras ferramentas geométricas. 
A quinta seção da unidade aborda a construção de triângulos, utilizando régua, esquadro e transferidor, e não compasso. As construções são apresentadas com etapas e imagens, auxiliando na compreensão do aluno.

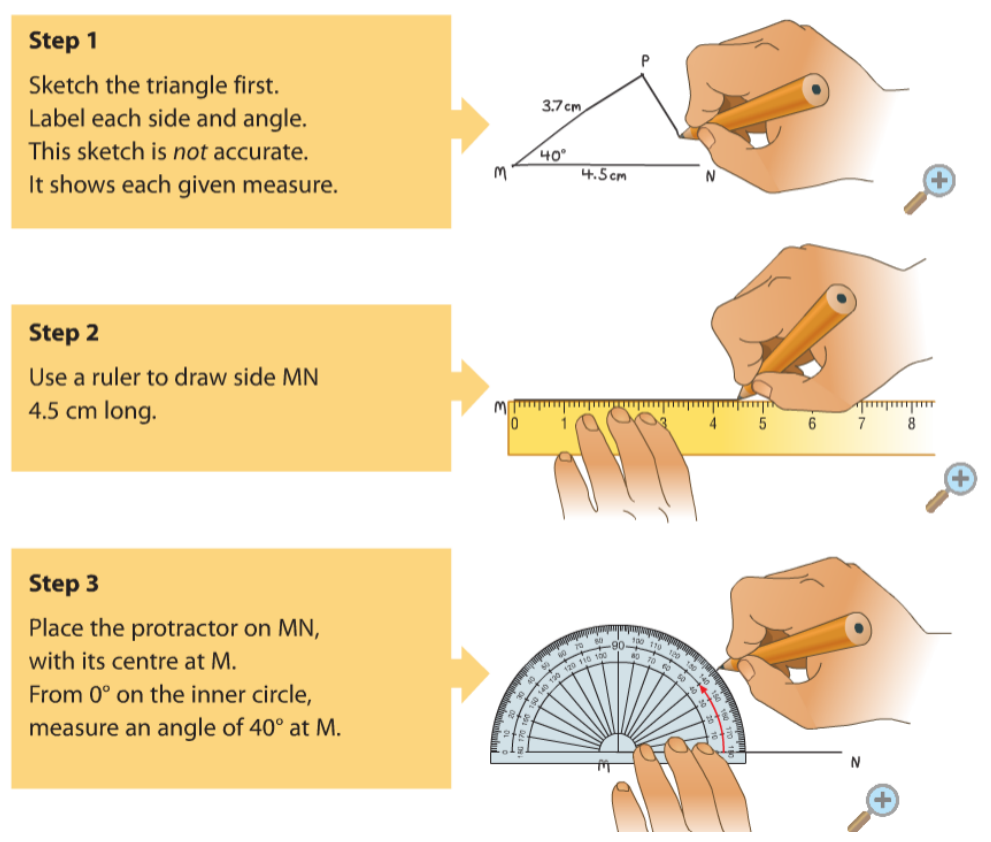

Figura 93 - Math makes sense 5 - p. 94
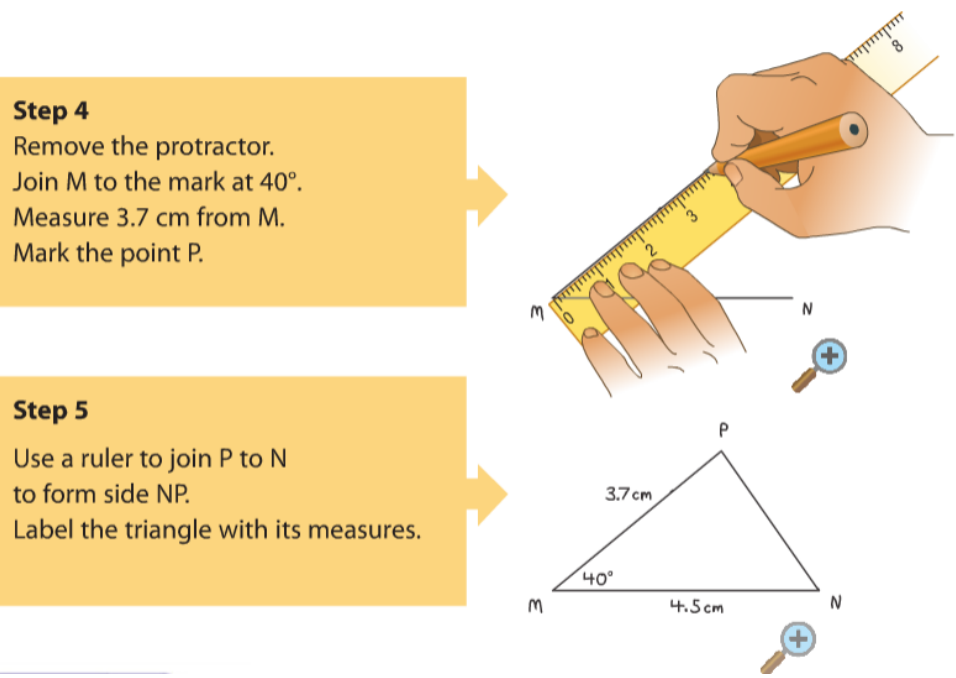

Figura 94 - Math makes sense 5 - p.95

Dois exercícios chamam a atenção no término da seção. Neles, os alunos são requisitados a construir dois triângulos impossíveis devido aos ângulos informados. A tarefa visa questionar sobre os requisitos para a construção dos triângulos, antes mesmo de aprenderem sobre a soma dos ângulos internos desses polígonos. 
6. Try to construct triangle $A B C$.

Draw AB 42 mm long.

The measure of $\angle A$ is $90^{\circ}$.

The measure of $\angle B$ is $95^{\circ}$.

Can you construct triangle $A B C$ ?

How do you know?

7. Can you construct a triangle with three $45^{\circ}$ angles?

Explain your thinking.

Figura 95 - Math makes sense 5 - p. 97

O problema da unidade (seção encontrada ao término da mesma) aborda a construção de pontes, ligando com as imagens encontradas no início dela. Nela, os alunos precisam construir triângulos, mas ainda sem abordar construção geométrica.

A seção sobre tecnologia também aborda a construção de polígonos, mas com um software mais simples, chamado AppleWorks ${ }^{34}$. Nele, os alunos constroem polígonos com apenas algumas etapas de forma simples e objetiva, porém sem seguir nenhum conceito da construção geométrica.

Na unidade 7, Transformational Geometry, Geometria transformacional, em tradução livre, temos os conteúdos de coordenadas cartesianas, alguns modelos de transformações, congruência de figuras e linha de simetria. Durante o capítulo não foi mencionado nenhum tipo de construção geométrica, além do geoboard e do software AppleWorks, sendo assim, os mesmos não serão comentados.

A nona unidade também aborda geometria, e se intitula Lenght, perimeter and area, em tradução livre Comprimento, perímetro e área. Semelhante ao que ocorre no capítulo 7, temos diversos assuntos envolvendo polígonos, mas não é utilizado construção geométrica. Nas seções sobre perímetro e área, as figuras já estão desenhadas, ou não dependem de qualquer desenho para resolução. As únicas ferramentas geométricas utilizadas são régua e geoboard.

O primeiro livro da coleção não aborda de forma incisiva a construção geométrica, além de ser voltado para crianças de 10/11 anos. Os assuntos ângulos e polígonos foram abordados de forma branda, portanto espera-se maior

\footnotetext{
${ }^{34}$ Software criado pela Apple Computer em 1984. Sua última atualização ocorreu no ano de 2004, um ano antes da publicação da obra Math Makes Sense
} 
profundidade nos demais livros, e também a oportunidade de desenvolver assuntos relacionados à construção geométrica.

\subsubsection{Math makes sense 6}

O segundo livro da coleção contém 463 páginas, distribuídas em 11 unidades e alguns paratextos, seguindo o mesmo modelo do livro anterior. No livro, temos 3 capítulos (totalizando 110 páginas) com enfoque em geometria. A capa, como toda a coleção, traz figuras que enaltecem a cultura canadense e, nessa, temos uma imagem de um lobo na neve. A palheta de cores é bem forte, com várias imagens e caixas de texto coloridas. A cor predominante do livro é o azul, encontrado no início de cada capítulo. Por se tratar de uma versão digital, os aspectos físicos não serão analisados. O manuseio no site da editora permanece simples e objetivo.

O terceiro capítulo do livro traz como tema geometria, sendo esse o nome do capítulo (Geometry no original). Na introdução do capítulo observamos uma cena do cotidiano e também alguns comentários sobre ângulos, em como eles estão em todos os lugares. Entre as palavras chave do capítulo temos ângulo reto e polígonos convexos, objetos esses nos quais é possível utilizar a construção geométrica.

No início do capítulo temos a utilização de régua e transferidor para medição e construção de ângulos. Os ângulos não são construídos com compasso, mas utiliza-se algumas ferramentas geométricas para isso, logo existe, mesmo que de forma superficial, uma construção geométrica. 
1. For each angle:

- Tell whether it is acute, right, obtuse, straight, or reflex.

- Estimate its measure.

- Measure to check.

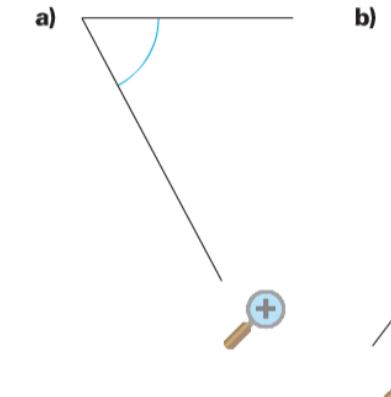

b)

2. Use a ruler and a protractor.

Draw an angle with each measure.
a) $205^{\circ}$
b) $200^{\circ}$
c) $270^{\circ}$
d) $300^{\circ}$
e) $350^{\circ}$

Figura 96 - Math makes sense 6 - p. 84

Algumas construções livres são encontradas no capítulo, nas quais os alunos não necessitam construir um polígono regular, ou copiar alguma imagem predeterminada. Nas figuras abaixo temos um exemplo dessa utilização, em que o aluno tem o papel de analisar e responder se os itens estão corretos ou não.

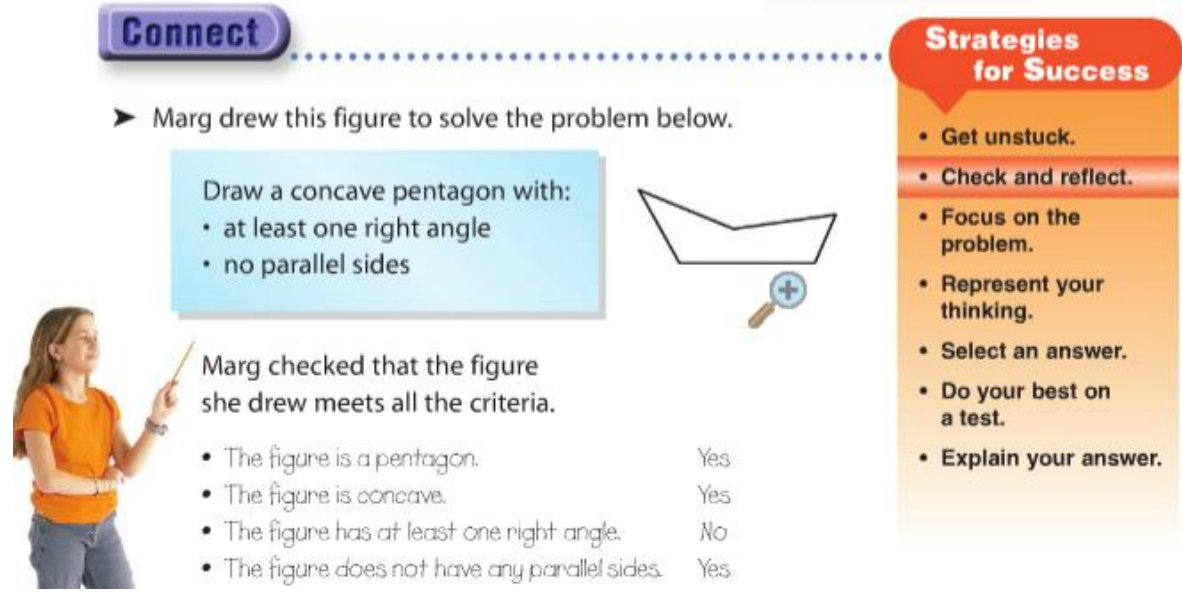

Figura 97 - Math makes sense 6 - p. 90

No quarto capítulo da unidade (Lesson 4 no original) temos como tema a construção de figuras. A primeira figura abordada é o triângulo e, para isso, os alunos utilizam régua e compasso. Como exemplo, constroem um triângulo com o conhecimento das medidas de seus lados. A construção é dividida em três etapas, como observado abaixo: 
Construct $\triangle A B C$ with sides $A B=6 \mathrm{~cm}$,

$A C=5 \mathrm{~cm}$, and $B C=4 \mathrm{~cm}$.

The $\triangle$ symbol means triangle

Step 1

Use the ruler to draw segment $\mathrm{AB} 6 \mathrm{~cm}$ long.

Step 2

Set the compass so the pencil and the compass point are $5 \mathrm{~cm}$ apart.

Place the compass point on $\mathrm{A}$.

Draw an arc.

Set the compass so the pencil and

the compass point are $4 \mathrm{~cm}$ apart.

Place the compass point on $\mathrm{B}$.

Draw an arc so the two arcs intersect.

Label the point $C$ where the arcs intersect.

Step 3

Draw segments $\mathrm{AC}$ and $\mathrm{BC}$ to complete the triangle.

Label each segment with its length.

When an angle is identifie

by three letters, the middle letter

indicates the vertex of the angle.

For example, $\angle \mathrm{A}$ is also $\angle \mathrm{CAB}$.
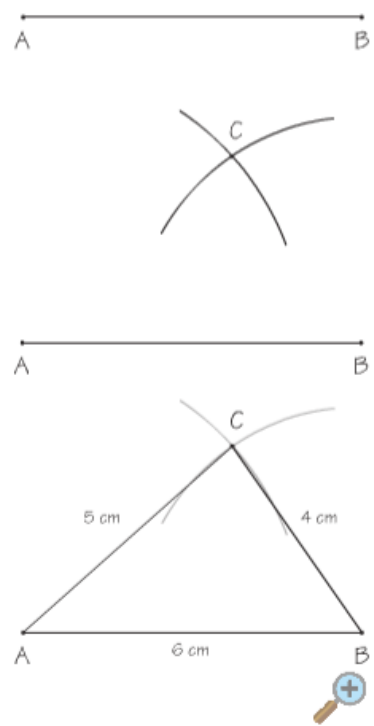

Figura 98 - Math makes sense 6 - p. 93

O mesmo acontece na construção de um paralelogramo, desta vez dividido em quatro etapas e com as informações de medidas de lados e ângulos. Nesse caso, também se utiliza transferidor.

Use a ruler and a protractor to construct parallelogram $B A C D$, with $A C=B D=5 \mathrm{~cm}, B A=D C=2 \mathrm{~cm}$,

$\angle A B D=120^{\circ}$, and $\angle B D C=60^{\circ}$.

\section{Step 1}

Use a ruler to draw

segment BD $5 \mathrm{~cm}$ long.
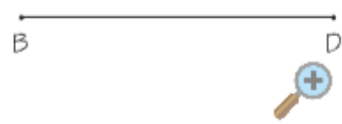

Step 2

At $B$, use the protractor

to measure $120^{\circ}$.

Draw segment BA $2 \mathrm{~cm}$ long.

\section{Step 3}

Use the protractor

to measure $60^{\circ}$ at $\mathrm{D}$.

Draw segment DC $2 \mathrm{~cm}$ long.

\section{Step 4}

Draw line segment AC

to complete the parallelogram.

Label each measure.

Check that $A C$ is $5 \mathrm{~cm}$ long.
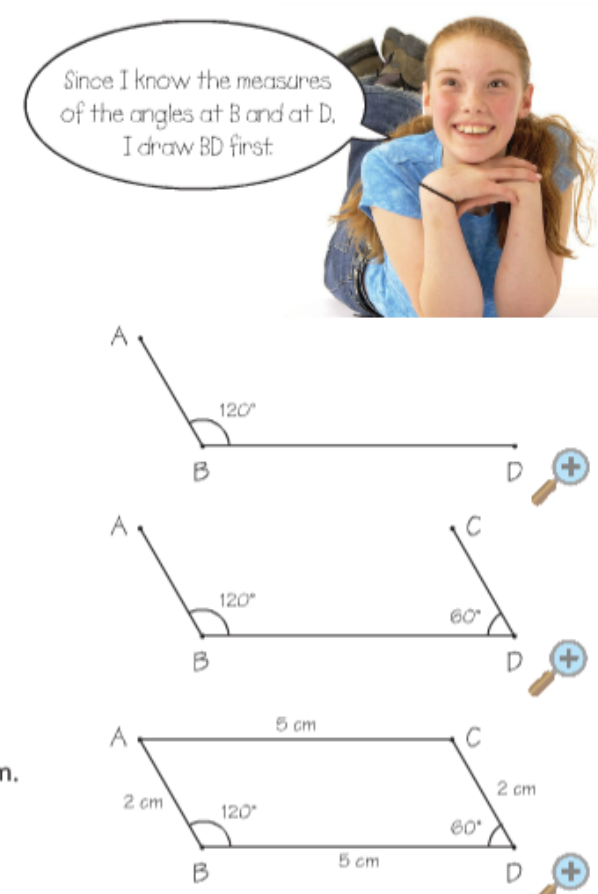

Figura 99 - Math makes sense 6 - p. 94 
$\mathrm{Na}$ lista de exercícios do capítulo, contamos com diversos itens sobre construção geométrica, mas analisaremos dois em particular, os itens 4 e 9 . No primeiro deles é solicitado a construção de um triângulo, mas apenas com as informações das medidas dos ângulos. Nesse caso, o aluno não possui um exemplo semelhante (ao menos no livro, pois foi apresentado no Math makes sense 5), logo deve utilizar todo o conhecimento recebido para criar suas próprias etapas de construção ou relembrar as etapas do ano anterior. No término do item, ainda se questiona sobre congruência de triângulos e suas propriedades.

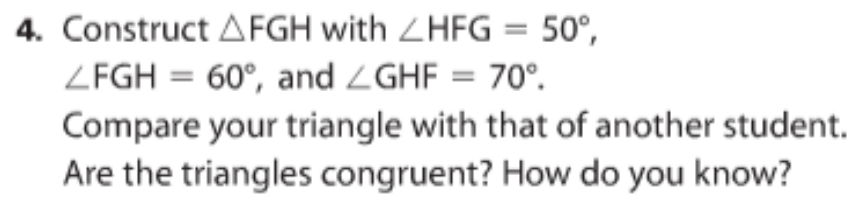

Figura 100 - Math makes sense 6 - p. 94.2

O segundo exercício segue o mesmo padrão, pedindo a construção de uma figura na qual o aluno não possui um exemplo no livro (nesse caso um pentágono). Esse tipo de exercício é fundamental para que o aluno possa, por conta própria, extrapolar todo o conhecimento adquirido nos exemplos e exercícios anteriores.

9. Construct two different pentagons $M N P Q R$ with these measures: $\mathrm{RQ}=\mathrm{QP}=\mathrm{PN}=6 \mathrm{~cm} ; \mathrm{RM}=\mathrm{MN}=4 \mathrm{~cm} ; \angle \mathrm{RQP}=\angle \mathrm{QPN}=90^{\circ}$ a) In each pentagon, find the measures of $\angle \mathrm{QRM}, \angle \mathrm{RMN}$, and $\angle \mathrm{MNP}$. b) Why is it possible to draw two different pentagons?

Figura 101 - Math makes sense 6 - p. 95

A seção Tecnology da unidade aborda o software Geometer's Sketchpad (já apresentado no livro anterior). A atividade apresentada envolve a construção e medição de um polígono, mas infelizmente o software em questão foi descontinuado, dificultando o seu uso nos dias atuais.

A unidade 7 (Transformational Geometry, em tradução livre Geometria transformacional) aborda os assuntos de simetria, em que as transformações são realizadas em papel quadriculado, não dependendo de nenhuma ferramenta geométrica. Ao longo do capítulo são solicitadas algumas construções de figuras e polígonos, mas sempre com o auxílio de papel quadriculado ou pontilhado (neste 
último o uso da régua é necessário), logo não é utilizado o método apresentado no capítulo anterior.

A nona unidade do livro, Perimeter, area and volume (em tradução livre Perímetro, área e volume), é também a última que aborda o tema geometria. Nela, como apresentado no título, aborda os conhecimentos de perímetro, área e volume. Da mesma forma que a unidade anterior, as construções de polígonos são realizadas em papel quadriculado ou pontilhado, portanto os conhecimentos adquiridos no capítulo 4 não são utilizados. Além disso, em sua grande maioria, as figuras já são apresentadas no próprio livro, restando, assim, apenas a resolução algébrica do exercício.

O segundo livro da coleção, a exemplo do primeiro, mantém pouca utilização da construção geométrica, repetindo alguns assuntos, como a construção de triângulos e ângulos utilizando o transferidor. De novidade, temos a construção de polígonos, mas sem a utilização de compasso (exceto triângulo). $O$ assunto ângulo é apresentado novamente, mas sua construção mantém-se focada no transferidor, não usufruindo desse momento para progredir o tema.

\subsubsection{Math makes sense 7}

O terceiro livro da coleção conta com 481 páginas, distribuídas entre 11 unidades e diversos paratextos ao longo da obra. Ao todo, existem 3 unidades com o tema geometria, com 114 páginas. Como nos demais livros, a fim de valorizar a cultura canadense, a capa traz a imagem de um leão da montanha, que é um animal que também faz parte de sua fauna. A palheta com cores fortes permanece, com foco no azul no início de cada capítulo. A versão analisada é digital, logo os aspectos físicos não serão abordados.

A unidade Geometry and Measurement (em tradução livre, Geometria e medição) é a primeira com tema focado em geometria. Entre os assuntos abordados, temos diversos poliedros e suas características.

Com o foco em geometria 3-D, existe poucas possibilidades de construção geométrica no capítulo. Os sólidos são apresentados nos próprios exercícios e, quando estão ausentes, as informações vitais para a resolução estão no enunciado. 
As planificações desses poliedros são exibidas nos próprios exercícios ou são oferecidas pelo professor, logo não há necessidade de construir polígonos.

Your teacher will give you a large copy of each net.

1. Fold this net to make a polyhedron.
a) Identify the polyhedron.
b) Describe the polyhedron.

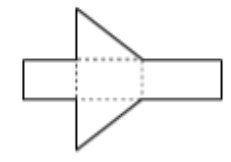

2. Fold this net.

a) Is the object a polyhedron? If so, what are the attributes that make it a polyhedron?

b) Identify parallel faces and

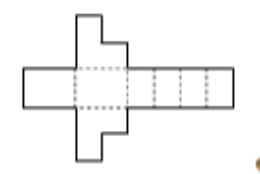
perpendicular faces.

3. Fold two of these nets to make two square pyramids with no base.

Tape the two pyramids together at their missing bases.

You have made a regular octahedron.

a) Why does it have this name?

b) Describe the octahedron.

How do you know it is regular?

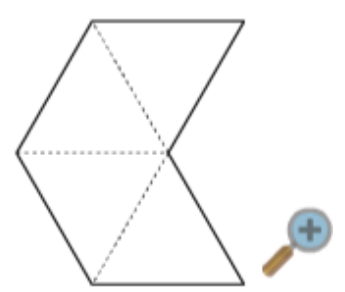

4. Fold each net. Describe each object.

How are the objects the same? How are they different?

a)

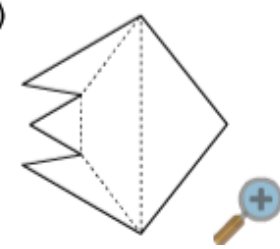

b)

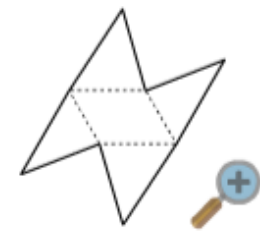

Figura 102 - Math makes sense 7 - p. 91

A sexta unidade do livro revisita os assuntos área e perímetro, desta vez acrescentando o polígono trapézio e cálculo de área de figuras irregulares. A apresentação das figuras mantém-se as mesmas, com malha quadriculada ou pontilhada, retirando a obrigação do aluno de construir os polígonos com ferramentas geométricas.

$\mathrm{Na}$ unidade seguinte, permanece o assunto geometria, desta vez com enfoque nos polígonos e transformações, tópicos já vistos. A única construção observada na unidade é do triângulo, abordada anteriormente nos dois livros da coleção.

O terceiro livro analisado é, até o momento, o de menor contribuição nos temas de construção geométrica. O único encontrado é uma revisitação do assunto, 
sem nenhuma construção nova. Mesmo os assuntos que não abordam possíveis construções, são recapitulações das obras anteriores, não avançando no tema como um todo.

\subsubsection{Math makes sense 8}

O último livro analisado da coleção conta com 559 páginas, distribuídas em 11 unidades e vários paratextos. Mantendo a consistência das obras, 3 capítulos são referentes à geometria, com um total de 122 páginas. A capa traz uma coruja, animal da fauna canadense, e a palheta de cores se mantém a mesma das demais obras. É relevante lembrar que a obra analisada é digital.

A primeira unidade com tema geometria aborda sólidos geométricos e suas características, não havendo oportunidades para a utilização da construção geométrica. Na seção sobre planificação de sólidos, as figuras são apresentadas no exercício ou pelo professor.

Pela primeira vez na coleção, temos uma unidade com enfoque em círculos e circunferência. Além de compreender o que são e onde encontrá-los no cotidiano, o aluno aprenderá suas características, cálculo de área e também como desenhar um círculo. As palavras-chave do capítulo são diâmetro, raio, circunferência e número irracional.

Na primeira seção do capítulo temos a construção de várias circunferências com diversas cordas e raios (termos ainda não utilizados). Nesse ponto, o aluno necessita compreender o manuseio de um compasso e, visando que já utilizou em livros anteriores (construção de um triângulo), isso não deve ser um problema. 


\section{Explore}

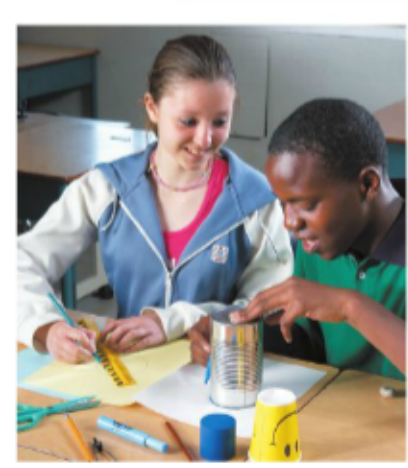

Work with a partner.

You will need circular objects, a compass, ruler, and scissors.

- Use a compass. Draw a large circle.

Use a ruler.

Draw a line segment that joins two points on the circle.

Measure the line segment. Label the line segment with its length.

Draw and measure other segments that join two points

on the circle.

Find the longest segment in the circle.

Repeat the activity for other circles.

- Trace a circular object.

Find a way to locate the centre of the circle.

Measure the distance from the centre to the circle.

Measure the distance across the circle, through its centre.

Record the measurements in a table.

Repeat the activity with other circular objects.

What pattern do you see in your results?

Figura 103 - Math makes sense 8 - p. 239

Entre os diversos exercícios sobre construção de circunferências, um se destaca, pois, além de solicitar a construção da circunferência e encontrar seu diâmetro, ainda pede para que o aluno encontre diversos pontos na circunferência e, com eles, construa diversos triângulos com o diâmetro.

8. a) Draw a circle.

Draw a diameter. Label it $\mathrm{AB}$.

Choose a point $\mathrm{P}$ on the circle.

Join AP and PB. Measure $\angle \mathrm{APB}$.

b) Choose another point $\mathrm{Q}$ on the circle.

Join $\mathrm{AQ}$ and $\mathrm{QB}$. Measure $\angle \mathrm{AQB}$.

c) Repeat parts a and b for a different circle.

What do you notice?

Figura 104 - Math makes sense 8 - p. 241

O exercício incentiva a observação e medição de ângulos, pois, assim, o aluno pode, com suas próprias construções, concluir conceitos matemáticos ligados a triângulos inscritos na circunferência.

Nas seções sobre comprimento e área de um círculo não há nenhuma inovação ao que já foi feito, nenhuma nova construção é necessária e o tema é abordado com todas as figuras já incorporadas no livro. O mesmo ocorre nas seções sobre cilindro. 
A unidade seguinte, intitulada Geometry (Geometria, em tradução livre), aborda ângulos, posições relativas de retas e retoma o tema circunferência. Logo no início da unidade é relembrado como medir ângulos utilizando um transferidor e construção de triângulos, conteúdo encontrado em todos os livros da coleção.

No assunto retas paralelas, os autores apresentam o tema na forma de exercício para os alunos, pois, assim, podem concluir por conta própria as propriedades do tema abordado. Para isso, é utilizado régua e papel pontilhado, e não régua e compasso como visto em algumas obras. Com o auxílio das ferramentas necessárias, os alunos constroem paralelogramos congruentes e, com isso, analisam os segmentos e formam seus lados.

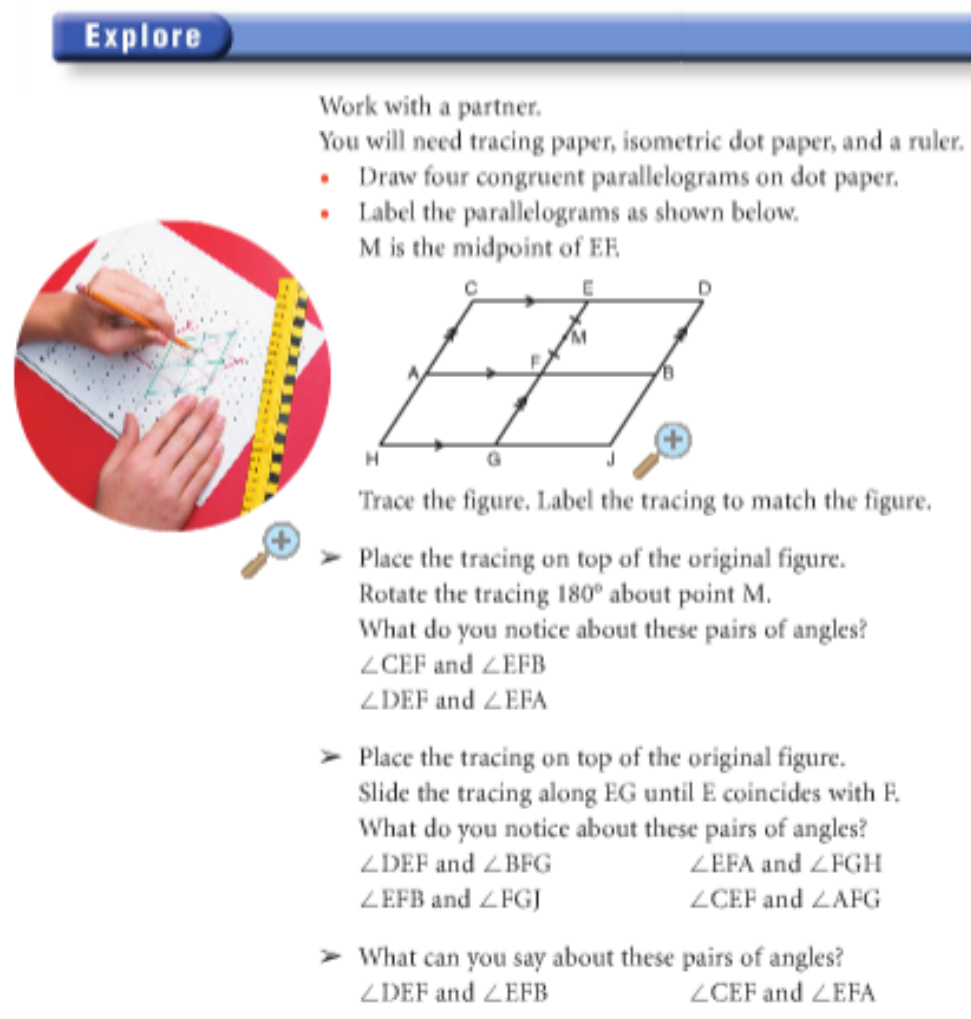

Figura 105 - Math makes sense 8 - p. 284

Mesmo não utilizando uma metodologia tradicional, ferramentas e conceitos geométricos são obrigatórios para sua resolução, tornando, assim, uma atividade de construção geométrica. Após o exercício, ainda é proposto uma comparação de resultados com os demais alunos da sala, gerando, assim, um debate sobre os temas ângulo e retas paralelas. 
A quarta seção da unidade traz conceitos fundamentais na construção geométrica: retas paralelas e bissetriz. Esses assuntos são abordados em todas as coleções, cada qual em uma série/ano diferente. A primeira construção da seção é a bissetriz perpendicular, segmento de reta que divide outro segmento em duas partes iguais formando um ângulo de $90^{\circ}$. No Brasil, utilizamos outro termo para essa construção, mediatriz. Toda a construção é apresentada em forma de etapas, acompanhadas de figuras para melhor visualização. As ferramentas utilizadas são régua e compasso.

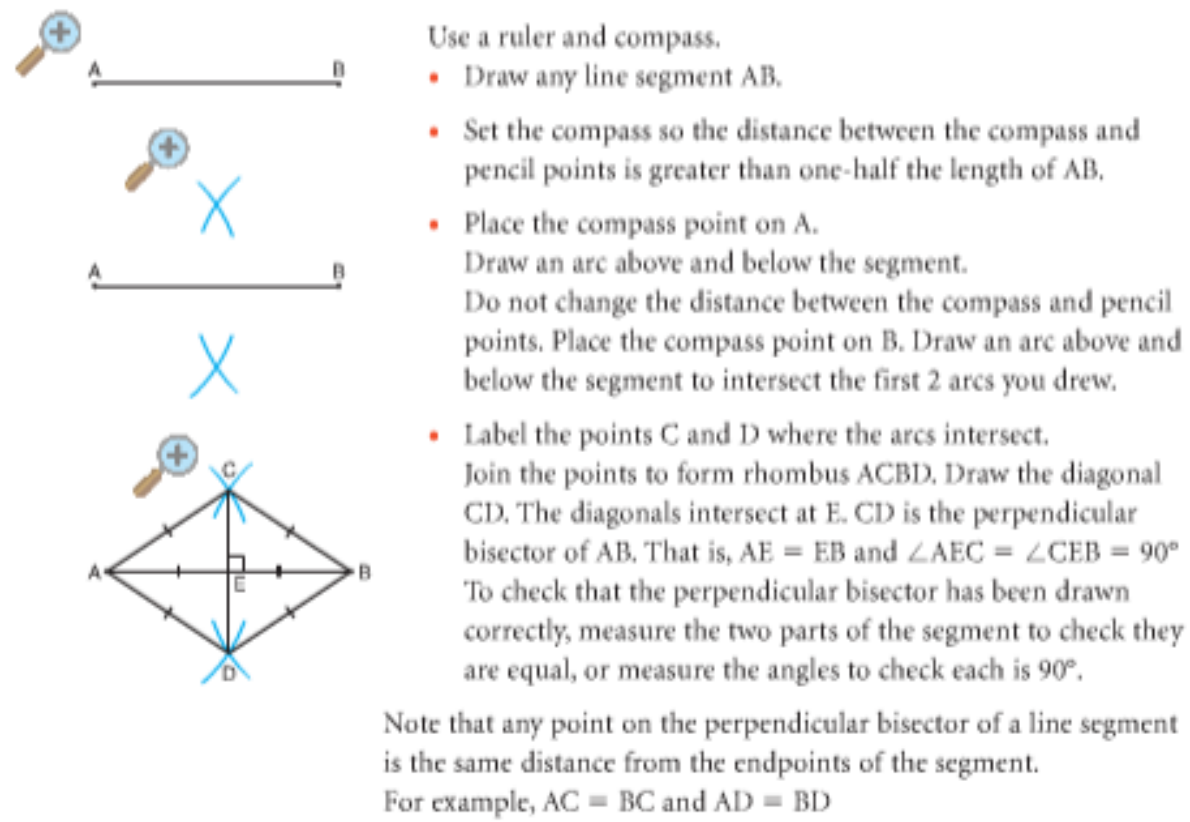

Figura 106 - Math makes sense 8 - p. 294

$\mathrm{Na}$ sequência, são apresentadas as etapas para construção da bissetriz angular, conhecida no Brasil apenas como bissetriz. Novamente os autores apresentam figuras de cada etapa, que auxiliam o aluno na utilização da régua e do compasso. A construção é tradicional, observada em várias obras sobre o tema. 


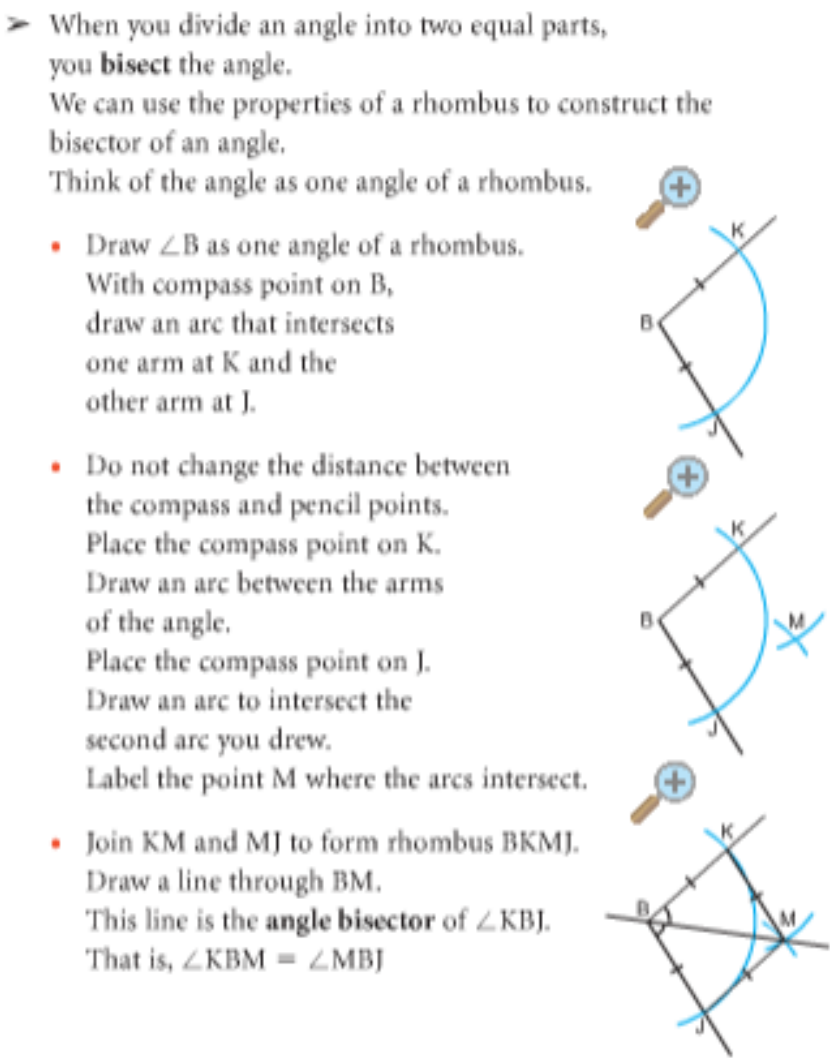

Figura 107 - Math makes sense 8 - p. 295.1

Como verificação, os autores sugerem algumas alternativas, como medição dos ângulos formados (utilizando mais uma ferramenta geométrica, o transferidor), realização de uma dobradura do papel no qual foi construído o ângulo exatamente na bissetriz para analisar se os ângulos coincidem e, por último, a utilização do Mira ${ }^{35}$.

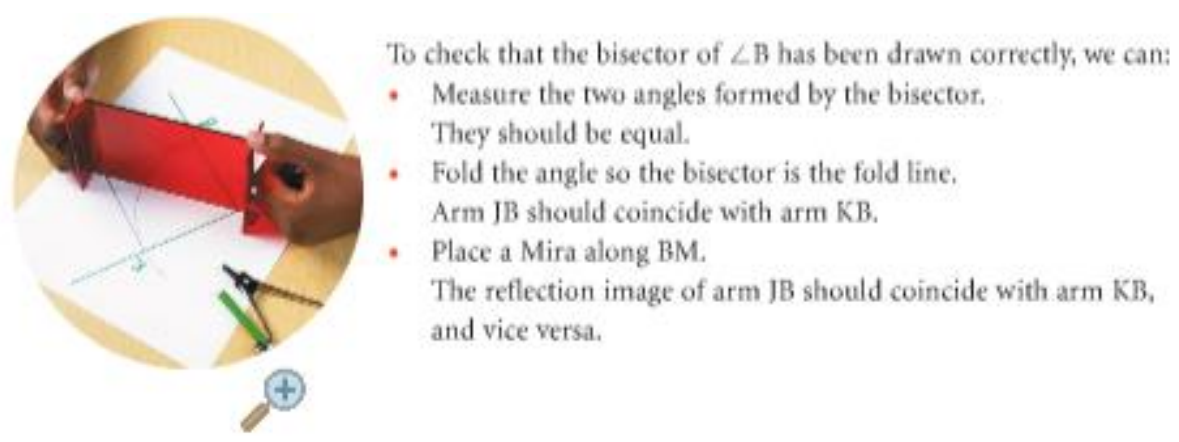

Figura 108 - Math makes sense 8 - p. 295.2

${ }^{35}$ Mira: Ferramenta geométrica construída em plástico projetada para explorar e ensinar conceitos de simetria e congruência. O objeto é transparente, mas funciona como um espelho, refletindo imagens ou objetos em uma folha de papel. Basta colocar o objeto em questão de um lado do Mira e observar seu reflexo do outro lado. 
Na seção de exercícios encontramos mais de dez questões sobre os temas abordados acima, mas somente dois deles se destacam. O primeiro (exercício 6) mescla as duas construções. Inicialmente o aluno deve construir a mediatriz de um segmento para, assim, construir as bissetrizes dos quatro ângulos retos formados na intersecção do segmento inicial com sua mediatriz.

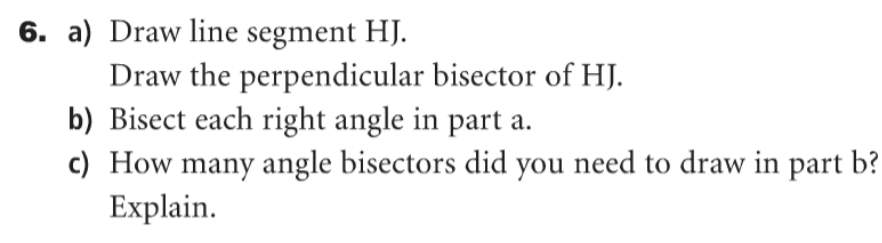

7. Draw a large $\triangle \mathrm{ABC}$. Cut it out. Fold the triangle so $\mathrm{B}$ and $\mathrm{C}$ coincide. Open the triangle. Fold it so A and B coincide. Open the triangle. Fold it so $\mathrm{A}$ and $\mathrm{C}$ coincide. Open the triangle. Use a ruler to draw a line along each crease.

a) Measure the angles each crease makes with one side. What do you notice?

b) Label point $\mathrm{K}$ where the creases meet. Measure KA, KB, and KC. What do you notice?

c) What have you constructed by folding?

Figura 109 - Math makes sense 8 - p. 297

O segundo (exercício 7) aborda diversos temas. De início, os alunos devem construir um triângulo (nesse ponto já é possível utilizar régua e compasso e seguir as etapas ensinadas) e recortá-lo. Com os nomes $\mathrm{A}, \mathrm{B}$ e $\mathrm{C}$ dados para cada vértice, os alunos devem dobrar o triângulo três vezes, primeiro coincidindo os pontos $B$ e $C$, depois os pontos $\mathrm{A}$ e $\mathrm{B}$ e, por último, os pontos $\mathrm{A}$ e $\mathrm{C}$. Com uma régua, o aluno deve desenhar as retas formadas pelas três dobras e nomear de $\mathrm{K}$ o ponto de encontro dos segmentos. Nesse momento o exercício aborda os conceitos de mediatriz do triângulo e circuncentro. Por último, ainda é solicitado a medição dos segmentos KA, KB e KC, demonstrando, assim, que as medidas são equidistantes.

Após a lista de exercícios, um pequeno texto informa que o circuncentro de um triângulo é o centro de gravidade do mesmo. O texto encoraja o aluno a testar tal afirmação, recortando um triângulo, colocando a ponta do lápis no ponto específico e tentando equilibrá-lo. 


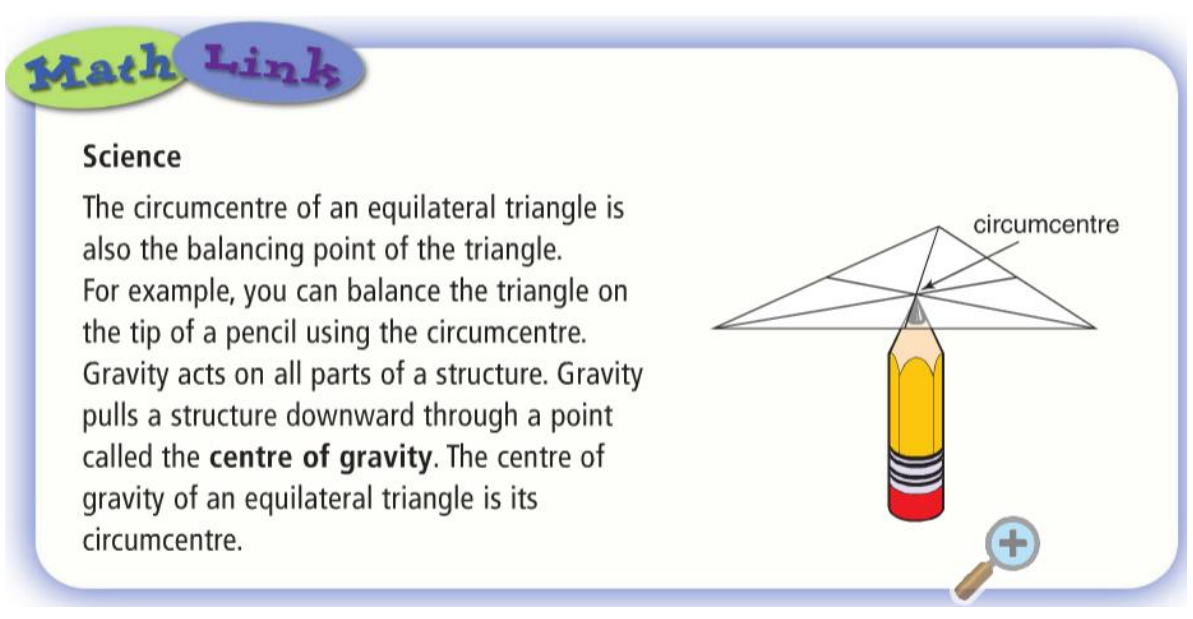

Figura 110 - Math makes sense 8 - p. 298

A quinta seção da unidade aborda a construção de ângulos com a utilização de compasso e régua. Os primeiros ângulos abordados são os de $90^{\circ}$ e 60․ Para a construção do ângulo reto, os autores utilizam a construção da mediatriz, e para o ângulo de 60ํㅡㄴ utilizam a construção de um triângulo equilátero.

Com as duas construções citadas acima e o conhecimento em encontrar a bissetriz de um ângulo, é possível construir os ângulos de $45^{\circ}$ e $30^{\circ}$. Os autores utilizam como exemplo a construção de um ângulo de 135․ Para isso, os autores dividem o ângulo desejado em duas partes, $90^{\circ}$ e 45ำ, para, assim, somá-las em um único ângulo. Para a construção do ângulo reto, utilizam a construção da mediatriz, formando quatro ângulos de 90․ Escolhe-se um desses ângulos e encontra-se sua bissetriz, um ângulo de 45ํ․ Com a construção dos dois, basta unir um dos ângulos de $45^{\circ}$ com um ângulo reto adjacente para construir um ângulo de $135^{\circ}$.

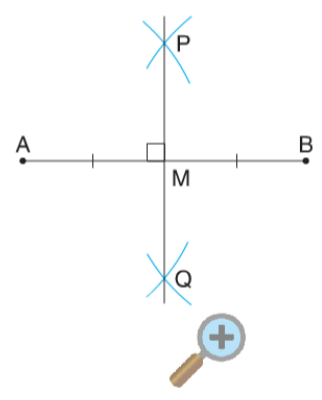

$>$ Here is one method to draw a $135^{\circ}$ angle. $135^{\circ}=90^{\circ}+45^{\circ}$

So, draw a $90^{\circ}$ angle and a $45^{\circ}$ angle at a common vertex.

Draw line segment $\mathrm{AB}$.

Use a ruler and compass to draw the perpendicular bisector of $\mathrm{AB}$.

Figura 111 - Math makes sense 8 - p. 299 


$$
\angle \mathrm{AMP}=\angle \mathrm{PMB}=90^{\circ}
$$

Use a ruler and compass to bisect $\angle \mathrm{PMB}$.

Label point $\mathrm{R}$ on the angle bisector.

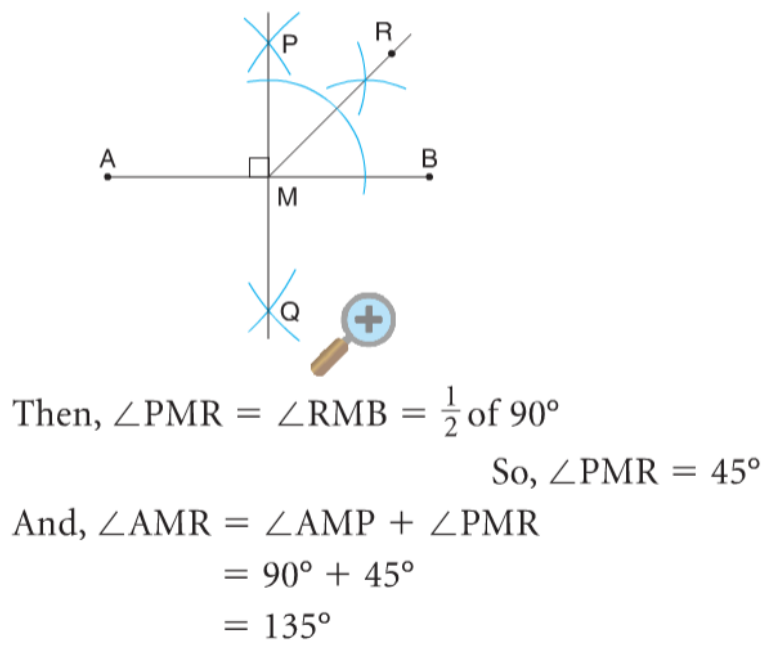

Figura 112 - Math makes sense 8 - p. 300

Diversos exercícios da seção abordam as mais variadas construções de ângulo, passando por construção de triângulos obtusângulos e paralelogramos. Entretanto, o que mais nos instigou nesse texto foi o paratexto Reflect. Nele, o aluno é questionado sobre todos os ângulos (entre $0^{\circ}$ e $180^{\circ}$ ) possíveis de construção utilizando régua e compasso. É solicitado a elaboração de uma lista com todas as construções possíveis e, na sequência, a construção de qualquer um desses ângulos.

\section{Reflect}

List all the angles between $0^{\circ}$ and $180^{\circ}$ you can construct using only a ruler and compass.

Choose one angle from the list. Construct the angle.

Describe how you did it.

Figura 113 - Math makes sense 8 - p. 302

O intrigante do exercício acima é o estímulo, o desafio que o aluno terá ao listar tais construções. Vários cálculos serão feitos para descobrir se tal ângulo é possível ou não construir. Um exemplo de ângulo que pode ser construído com régua, compasso e construções já apresentadas no livro é 105을 pois $105^{\circ}=90^{\circ}+$ 15․ O ângulo de $90^{\circ}$ é construído através da mediatriz e o ângulo de $15^{\circ}$ é construído através da bissetriz do ângulo de $30^{\circ}$ que, por sua vez, é a bissetriz do 
ângulo de 60, o qual é possível construir através de um triângulo equilátero. A imaginação do aluno é fundamental para descobrir todas as construções possíveis.

O restante da unidade aborda algumas classificações e exercícios com o viés algébrico, não abordando as construções em si. Com isso, termina-se o último livro da coleção, no qual o tema construção geométrica foi mais destacado em comparação aos demais livros da coleção.

A coleção Math makes sense não aborda de forma harmoniosa os temas de construção geométrica, os livros 5 e 7 possuem pouco, ou nenhum tema sobre o assunto. Mas, por outro lado, o livro 8 aborda diversas construções e habilidades sobre o tema. Algumas construções encontradas na obra não aparecem nas demais coleções analisadas, como a construção de ângulos com régua e compasso.

\begin{tabular}{|l|l|}
\hline Conteúdo & Ferramentas \\
\hline Ângulo & Régua, transferidor e compasso \\
\hline Bissetriz & Régua, compasso e mira \\
\hline Circunferência & Compasso \\
\hline Mediatriz e circuncentro & Régua e compasso \\
\hline Paralelogramo & Régua e esquadro \\
\hline Polígonos & Geoboard \\
\hline Quadriláteros & Geoboard \\
\hline Reta paralela & Régua, papel pontilhado e compasso \\
\hline Reta perpendicular & Régua e compasso \\
\hline Triângulo & Régua, transferidor e compasso \\
\hline
\end{tabular}

Quadro 6 - Conteúdos de construção geométrica Math Makes Sense 


\section{ANÁLISE COMPARATIVA DAS QUATRO OBRAS}

A construção geométrica está presente em toda a história da Matemática, e sua importância é inegável na educação. Porém, atualmente, sua utilização é escassa, muitas vezes inexistente, mesmo que esteja proposta em documentos oficiais como PCNs e The Ontario Curriculum. Com isso, a primeira etapa de análise consiste em verificar se tais obras estão de acordo com os documentos oficiais.

Os Parâmetros Curriculares Nacionais não elaboram uma lista de conteúdos em si, mas sim algumas sugestões em que os professores possam se basear. Entre os conteúdos encontrados nessas sugestões, temos: retas paralelas, perpendiculares, mediatriz, bissetriz, altura, mediana e divisão de segmentos. $O$ primeiro ponto interessante é a inexistência de uma orientação clara para construções de ângulos e polígonos, construções essas consideradas comuns em diversos trabalhos sobre o tema construção geométrica.

A primeira obra analisada, Projeto Teláris, aborda construções geométricas sugeridas nos PCNs, com exceção da mediana e altura do triângulo (assuntos abordados nos livros, mas sem a utilização da construção geométrica). Além das construções ou atividades sugeridas, ainda implementam diversas outras, como os já citados ângulos e triângulos, e é a única obra que aborda a construção do retângulo de ouro.

A segunda obra analisada, Matemática Na Medida Certa, aborda três dos temas sugeridos: retas paralelas, mediatriz e bissetriz. Infelizmente, a maioria das sugestões não são abordadas (em forma de construção geométrica): retas perpendiculares, divisão de segmentos em partes iguais, mediana e altura.

Além dos temas, os PCNs sugerem a utilização de ferramentas geométricas, como régua, compasso, transferidor e esquadros. Nesse aspecto, as duas coleções seguem a orientação e utilizam as ferramentas, cada qual com atividades específicas. Em alguns momentos, as atividades propostas utilizam mais de uma ferramenta, com destaque no compasso nas construções de ângulos, por exemplo. Nas obras analisadas, essas construções são realizadas apenas com transferidor. 
O Ontario Curriculum, diferente dos PCNs, elabora uma lista de conteúdos e habilidades que o aluno necessita compreender até o término do ano letivo. Em relação a construções geométricas, temos os seguintes conteúdos: retas paralelas, perpendiculares, ângulos, figuras planas (polígonos), triângulos, quadriláteros, bissetriz e circunferência. $O$ uso das ferramentas também é comentado.

A terceira obra analisada, Nelson Mathematics, aborda cinco dos oito conteúdos listados no currículo. São eles: triângulos, quadriláteros, figuras planas (polígonos), reta perpendicular e circunferência. Nos quatro livros da coleção, os autores não apresentam o passo a passo para construção de ângulos, mas utilizam desse conhecimento na construção de figuras planas. Não fica claro se o conteúdo já foi apresentado nos primeiros livros da coleção (volumes 1 a 4) ou apenas deixaram para o professor apresentar tal conceito. Uma pesquisa mais aprofundada com os livros iniciais deve ser realizada para responder essa questão.

A construção de quadriláteros também não aparece de forma individualizada, mas sim como exemplos de figuras planas construtíveis com régua e transferidor. Construção de retas paralelas e bissetriz não aparece na obra como um todo. Os livros não abordam outras construções além das encontradas no currículo.

A quarta, e última, coleção, Math Makes Sense, aborda todos os conteúdos apresentados no currículo de Ontário, mas com algumas observações importantes. A construção de figuras planas e quadriláteros é feita apenas no geoplano, então não utilizam régua, compasso, transferidor ou esquadros, com exceção de paralelogramos, que utilizam régua e esquadro. A construção de retas perpendiculares é de forma genérica, apresentando apenas a mediatriz (no Canadá é chamada de bissetriz perpendicular). Mesmo com restrições, Math Makes Sense é a obra que mais se aproxima do currículo.

Nota-se que nas obras canadenses a utilização de softwares de geometria dinâmica é superior as obras brasileiras. Os livros brasileiros analisados foram editados pelo menos dez anos após os canadenses, o que tornaria mais atuais. Assim, a expectativa é que tivessem igual ou maior uso de softwares, mas isso não acontece. Salienta-se novamente que a utilização do software não foi analisada como um todo, já que necessita de uma análise separada. 
Ao longo das quatro coleções encontramos diversas construções, com ferramentas e metodologias diferenciadas. Porém, algo não se altera, a maneira como o conceito matemático é abordado. Algumas construções são comuns em todas as coleções, outras são exclusivas de apenas uma, como vemos no quadro a seguir.

\begin{tabular}{|c|c|c|c|c|}
\hline Conteúdo & Projeto Teláris & $\begin{array}{l}\text { Matemática Na } \\
\text { Medida Certa }\end{array}$ & $\begin{array}{l}\text { Nelson } \\
\text { Mathematics }\end{array}$ & $\begin{array}{l}\text { Math Makes } \\
\text { Sense }\end{array}$ \\
\hline Ângulo & Transferidor & & & $\begin{array}{l}\text { Régua, } \\
\text { transferidor e } \\
\text { compasso }\end{array}$ \\
\hline Ângulo reto & $\begin{array}{l}\text { Régua e } \\
\text { esquadro }\end{array}$ & & & \\
\hline Bissetriz & Sem ferramentas & $\begin{array}{l}\text { Régua e } \\
\text { compasso }\end{array}$ & & $\begin{array}{l}\text { Régua, compasso } \\
\text { e mira }\end{array}$ \\
\hline Circuncentro & $\begin{array}{l}\text { Régua e } \\
\text { compasso }\end{array}$ & & & $\begin{array}{l}\text { Régua e } \\
\text { compasso }\end{array}$ \\
\hline Circunferência & Compasso & Compasso & Compasso & Compasso \\
\hline $\begin{array}{ll}\text { Divisão } & \text { de } \\
\text { segmentos } & \end{array}$ & $\begin{array}{l}\text { Régua e } \\
\text { compasso }\end{array}$ & & & \\
\hline Hexágono & $\begin{array}{l}\text { Régua, compasso } \\
\text { e transferidor }\end{array}$ & & & \\
\hline Incentro & & $\begin{array}{l}\text { Régua e } \\
\text { compasso }\end{array}$ & & \\
\hline Mediatriz & $\begin{array}{l}\text { Régua e } \\
\text { compasso }\end{array}$ & $\begin{array}{l}\text { Régua e } \\
\text { compasso }\end{array}$ & & $\begin{array}{l}\text { Régua e } \\
\text { compasso }\end{array}$ \\
\hline Paralelogramo & & & $\begin{array}{l}\text { Régua, } \\
\text { transferidor e } \\
\text { geoplano }\end{array}$ & $\begin{array}{l}\text { Régua e } \\
\text { esquadro }\end{array}$ \\
\hline Polígonos & & $\begin{array}{l}\text { Régua, compasso } \\
\text { e transferidor }\end{array}$ & $\begin{array}{l}\text { Régua e } \\
\text { transferidor }\end{array}$ & Geoplano \\
\hline Quadrilátero & & $\begin{array}{l}\text { Régua e } \\
\text { esquadro }\end{array}$ & $\begin{array}{l}\text { Régua e } \\
\text { transferidor }\end{array}$ & Geoplano \\
\hline $\begin{array}{l}\text { Retângulo de } \\
\text { ouro }\end{array}$ & $\begin{array}{l}\text { Régua e } \\
\text { compasso }\end{array}$ & & & \\
\hline Reta paralela & $\begin{array}{l}\text { Régua e } \\
\text { compasso }\end{array}$ & $\begin{array}{l}\text { Régua e } \\
\text { esquadro }\end{array}$ & & $\begin{array}{l}\text { Régua, papel } \\
\text { pontilhado e } \\
\text { compasso }\end{array}$ \\
\hline $\begin{array}{l}\text { Reta } \\
\text { perpendicular }\end{array}$ & $\begin{array}{l}\text { Régua e } \\
\text { compasso }\end{array}$ & & $\begin{array}{l}\text { Régua e } \\
\text { compasso }\end{array}$ & $\begin{array}{l}\text { Régua e } \\
\text { compasso }\end{array}$ \\
\hline Triângulo & $\begin{array}{l}\text { Régua, } \\
\text { transferidor e } \\
\text { compasso }\end{array}$ & $\begin{array}{l}\text { Régua e } \\
\text { compasso }\end{array}$ & $\begin{array}{l}\text { Régua e } \\
\text { transferidor }\end{array}$ & $\begin{array}{l}\text { Régua, } \\
\text { transferidor e } \\
\text { compasso }\end{array}$ \\
\hline
\end{tabular}

Quadro 7 - Construções geométricas nas quatro coleções

Fonte: elaborada pelo autor

Algumas observações sobre o quadro são pertinentes. Por exemplo, paralelogramos, quadriláteros, triângulos e hexágonos são polígonos, porém em diversos casos existe a construção de alguma forma geométrica específica, e não de todos os polígonos, logo é necessário a diferenciação nos quadros. O mesmo ocorre para ângulos e ângulo reto. Não foram acrescentados nos quadros as construções via softwares, por isso decidimos analisar essa utilização em um trabalho futuro, focando na tecnologia nas aulas de geometria. 
As quatro coleções abordam as construções geométricas e, comum a todas, estão as construções de circunferências e triângulos. Em relação à circunferência não há nenhuma novidade, todas utilizam o compasso. Quanto ao triângulo, apenas uma coleção não utiliza essa ferramenta, Nelson Mathematics, coleção na qual só utiliza a ferramenta em duas ocasiões: circunferência e reta perpendicular. Outro ponto interessante dessa coleção é a quantidade de construções, apenas seis, a menor entre as coleções analisadas.

Ao todo, temos 16 construções no quadro 7 , levando em consideração alguns comentários acima. Projeto Teláris aborda 12 dessas construções, Matemática $\mathrm{Na}$ Medida Certa, 8, Nelson Mathematics, como já citado, aborda 6 construções e Math Makes Sense, um total de 11. Quantitativamente, as coleções brasileiras apresentam um maior número de construções geométricas. Entretanto, esses valores não refletem diretamente na qualidade dos materiais, nem mesmo em sua eficácia em abordar os temas, mas traz um ponto de partida para comparações.

Entre as construções exclusivas de uma coleção, temos divisão de segmentos em partes iguais, hexágono e retângulo de ouro, todos da coleção Projeto Teláris (ângulo reto aparece como um dos ângulos construtíveis na coleção Math Makes Sense). Outra construção exclusiva é o incentro na coleção Matemática Na Medida Certa. Dessas, a única presente no currículo específico de seu país é a divisão de segmentos iguais, encontrada nos PCNs.

Um diferencial nas coleções canadenses em relação às brasileiras é a utilização das ferramentas geoplano e mira. Tais ferramentas não são comuns nas obras brasileiras, geoplano é citado no Projeto Teláris, mas não é utilizado e mira nem é citado. Essas ferramentas facilitam na construção de conceitos geométricos pelo aluno, pois permitem uma visão física do objeto, além de sua praticidade e fácil compreensão.

Ainda sobre ferramentas, diversas vezes o compasso foi substituído, seja por um esquadro como nas construções de retas paralelas, quadriláteros, ângulos retos ou até mesmo por simples dobraduras ou mira, como na construção de bissetrizes. A utilização dessas ferramentas é importante, mas deve-se apresentar outras formas de construção, como a de utilização do compasso. 
Outras diferenças são encontradas entre obras brasileiras e canadenses, como vemos no quadro abaixo:

\begin{tabular}{|l|l|l|}
\hline Conteúdo & Obras brasileiras & Obras canadenses \\
\hline Ângulo & Projeto Teláris & Math Makes Sense \\
\hline Ângulo reto & Projeto Teláris & \\
\hline Bissetriz & Duas obras & Math Makes Sense \\
\hline Circuncentro & Projeto Teláris & Math Makes Sense \\
\hline Circunferência & Duas obras & Duas obras \\
\hline Divisão de segmentos & Projeto Teláris & \\
\hline Hexágono & Projeto Teláris & \\
\hline Incentro & Matemática na Medida Certa & \\
\hline Mediatriz & Duas obras & Math Makes Sense \\
\hline Paralelogramo & & Duas obras \\
\hline Polígonos & Matemática na Medida Certa & Duas obras \\
\hline Quadrilátero & Matemática na Medida Certa & Duas obras \\
\hline Retângulo de ouro & Projeto Teláris & Duath Makes Sense \\
\hline Reta paralela & Duas obras & Duas obras \\
\hline Reta perpendicular & Projeto Teláris & Duas obras \\
\hline Triângulo & Quadro - Comparatvo entre passes \\
\hline
\end{tabular}

Quadro 8 - Comparativo entre países

Fonte: Elaborada pelo autor

Alguns pontos interessantes dessa comparação é a ausência de cinco temas nas obras canadenses (ângulo reto, divisão de segmentos em partes iguais, hexágono, incentro e retângulo de ouro) contra apenas uma nas obras brasileiras (paralelogramo). Nesse aspecto é necessário reiterar que, paralelogramo é um polígono, então mesmo não abordado de forma individualiza, é encontrado no tema polígono na obra Matemática na Medida Certa. Ângulo reto e hexágono também são partes de temas maiores (ângulos e polígonos), então o mesmo se aplica, sendo possível encontrá-los nas respectivas seções das obras canadenses.

Também é observado que, todas as construções encontradas na obra Nelson Mathematics são encontradas na obra Math Makes Sense. Isso não ocorre nas brasileiras, existe diferenças entre as construções das duas obras. 
Entre as construções encontradas simultaneamente nas quatro obras temos a construção de triângulos, então, analisaremos como cada obra aplica esse conhecimento.

\section{Condição de existência de um triângulo}

Fábio construiu, com régua e compasso, um triângulo com lados de $4 \mathrm{~cm}, 3 \mathrm{~cm}$ e $2 \mathrm{~cm}$, representado a seguir.

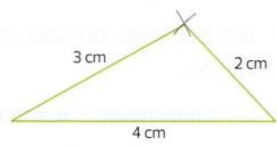

Denise tentou construir um triângulo com lados de $4 \mathrm{~cm}, 2 \mathrm{~cm}$ e $1,5 \mathrm{~cm}$, mas não conseguiu.

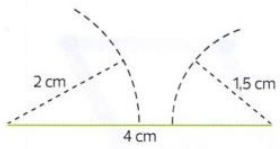

Ficou, então, a pergunta: "Em que condição, dadas as medidas de três segmentos de reta, é possivel construir um triângulo cujos lados tenham essas medidas?". Procure encontrar a resposta fazendo o exercício a seguir.

Figura 114 - Projeto Teláris - matemática 8 - p. 96

Na primeira obra analisada, Projeto Teláris, a construção desse polígono é apresentada como "condição de existência", não como construção em si. O autor aborda a construção com régua e compasso, e informando a medida de seus três lados. A construção envolvendo os valores dos ângulos não é apresentada.

\section{Construção de um triângulo conhecendo-se os lados}

Vamos mostrar a construção de um triângulo com lados de $2 \mathrm{~cm}, 3 \mathrm{~cm}$ e $4 \mathrm{~cm}$. Para isso, usaremos régua e compasso.

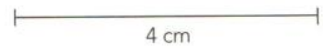

Trace o lado maior.

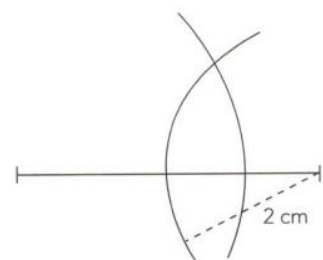

Com centro na outra extremidade, trace uma circunferência $\mathrm{com} 2 \mathrm{~cm}$ de raio, para obter o lado de $2 \mathrm{~cm}$

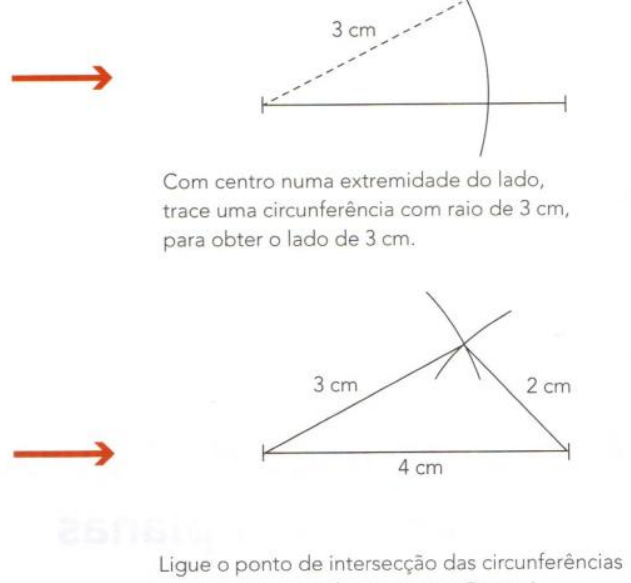

com os extremos do segmento. Pronto!

Figura 115 - Matemática na medida certa 8 - p. 196 
Na segunda obra, Matemática na Medida Certa, os autores também apresentam a construção do triângulo conhecendo seus três lados, mas desta vez com um título mais adequado, tornando claro que se trata de uma construção. Também não foi abordado a construção de triângulos conhecendo seus ângulos.

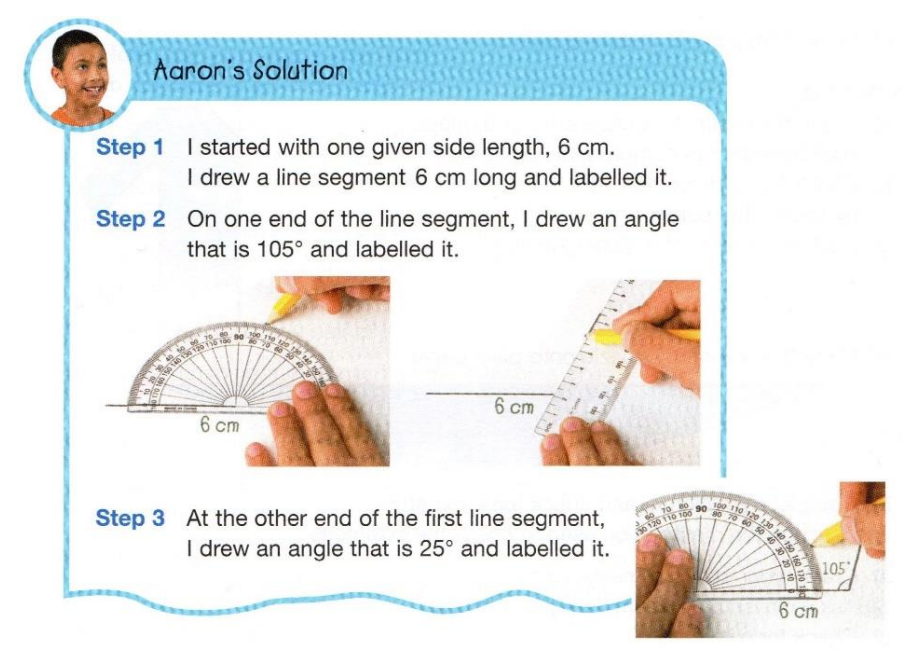

Figura 116 - Nelson Mathematics 5 - p. 192

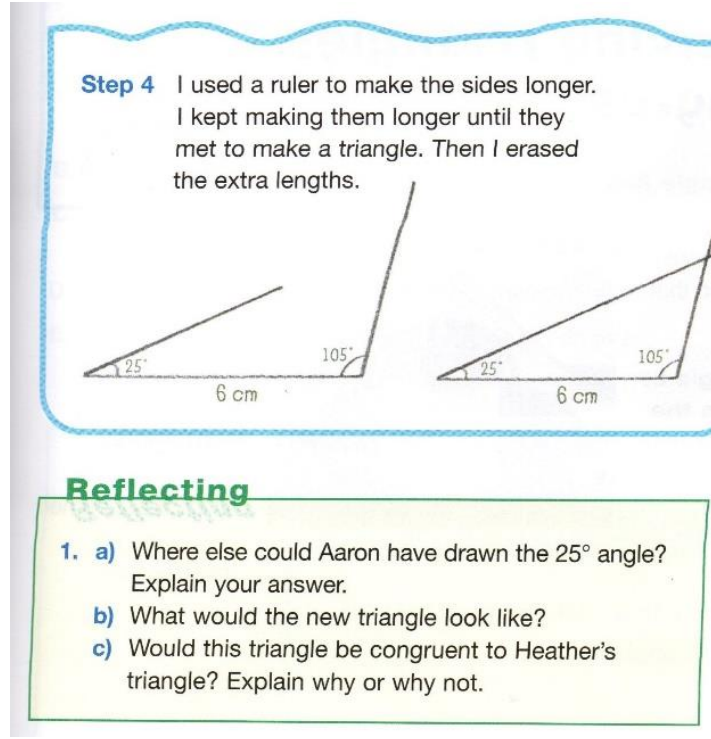

Figura 117 - Nelson Mathematics 5 - p. 193

Na primeira obra canadense, Nelson Mathematics, a construção de triângulos é apresentada de outra forma. Nesse caso, as autoras abordam a construção desse polígono conhecendo um dos lados e dois ângulos, diferente da abordagem encontrada nas obras brasileiras analisadas. 


\section{Step 1}

Sketch the triangle first

Label each side and angle.

This sketch is not accurate.

It shows each given measure.

Step 2
Use a ruler to draw side MN
$4.5 \mathrm{~cm}$ long.

Step 3

Place the protractor on $\mathrm{MN}$,

with its centre at $M$

From $0^{\circ}$ on the inner circle,

measure an angle of $40^{\circ}$ at $\mathrm{M}$.
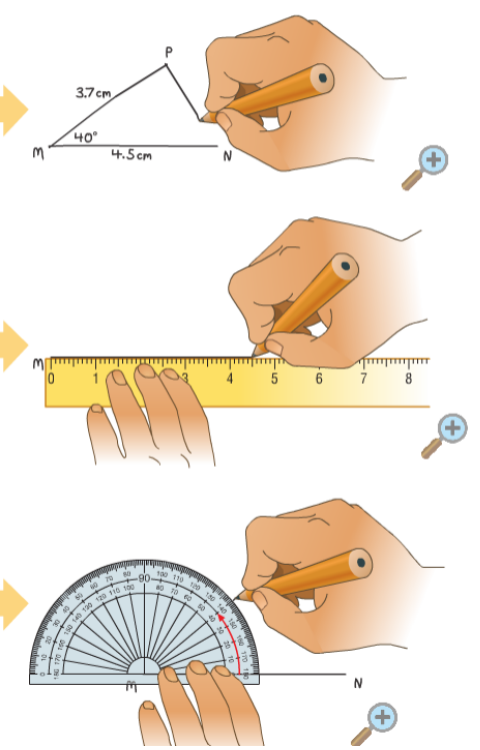

Figura 118 - Math Makes Sense 5 - p. 94
Step 4

Remove the protractor.

Join $\mathrm{M}$ to the mark at $40^{\circ}$

Measure $3.7 \mathrm{~cm}$ from $\mathrm{M}$.

Mark the point $P$.
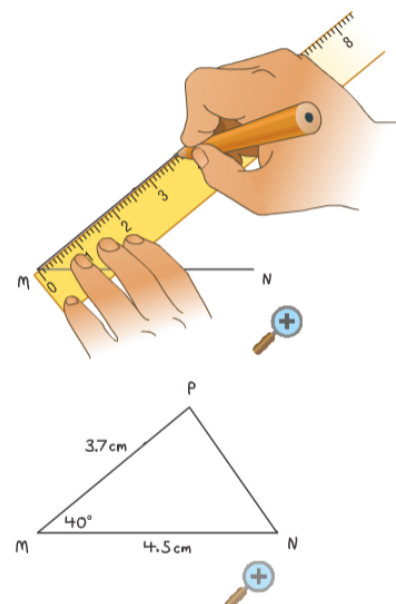

Figura 119 - Math Makes Sense 5 - p. 95

Na última obra analisada, Math Makes Sense, a construção de triângulos é abordava de uma terceira forma, conhecendo as medidas de dois de seus lados e o ângulo entre eles. Nota-se que cada obra utiliza uma forma distinta de abordar o mesmo assunto, mas todas abordam essa construção.

Nota-se também que, as obras brasileiras abordam o tema construção de triângulos no $8^{\circ}$ ano, enquanto as canadenses abordam no $5^{\circ}$ ano. 


\section{CONSIDERAÇÕES FINAIS}

Livros didáticos são reflexos da sociedade na qual estão inseridos. Diferenças aparecerão, e observamos isso como algo positivo, pois houve adequação para o público em questão, como metodologias voltadas para aspectos de culturas específicas. Porém, conceitos matemáticos formalizados são comuns em todas as culturas, sempre com os mesmos símbolos, formulações e ferramentas.

Sabe-se que o foco principal dos livros didáticos não é a construção geométrica, basta verificar a quantidade de páginas focadas em geometria e, dessas, quantas abordam alguma construção em si, mas isso não minimiza a sua importância, logo, mesmo as coleções mais completas, ainda precisam acrescentar conceitos e construções, além de exercícios, projetos e oficinas que utilizam desse conhecimento.

Todas as obras analisadas abordam o tema construção geométrica em seus livros, cada qual com uma frequência, metodologia e ferramentas distintas. Observamos no capítulo anterior as diversas formas de inserir a construção de triângulos, todas válidas.

Duas obras se destacam, uma de cada país, Projeto Teláris e Math Makes Sense. O destaque dá-se por algumas características, como aproximação com o currículo (lembrando que Math Makes Sense é a única obra a cumprir o currículo como um todo), pela quantidade e qualidade das construções e por ir além, trazendo construções não citadas nos documentos oficiais. As demais obras não cumprem todas as recomendações e, além disso, apresentam construções menos elaboradas.

Além das construções, a utilização das ferramentas é uma etapa fundamental na compreensão da geometria. As obras utilizam muito a régua, compasso, transferidor e esquadro, cada qual com sua utilidade, muitas vezes demonstrando mais de uma forma de construir o mesmo objeto, como a construção de triângulos com régua e compasso e régua e transferidor.

Para explicar as razões que levaram os autores a optarem por tais abordagens, seria necessária uma pesquisa mais aprofundada envolvendo autores e 
editoras. Podemos sim salientar que com a falta dessas construções houve perda na aprendizagem do aluno, já que outros alunos, com outras obras, desenvolvem essas habilidades.

Ao todo, percebe-se que ainda existe bastante conteúdo sobre o tema construção geométrica a ser apresentado nos anos finais do ensino fundamental, porém, a mudança não deve ser apenas do livro didático, mas de todo o sistema de ensino, partindo dos currículos, demais documentos oficiais, editoras, autores e professores, todos salientando a importância desse tema.

Mesmo que cada coleção conte seus pontos positivos e negativos, ao todo, existe balanceamento entre os livros brasileiros e canadenses, sendo que, pelo menos uma das coleções de cada país aproxima-se de ser completa em relação a seguir as recomendações curriculares e apresentarem quantidade e qualidade nas construções geométricas. O grande vão que existe entre os níveis educacionais encontrados pelo PISA não são, inicialmente, encontrados no livro didático usado pelo professor e alunos. Possivelmente existem outros fatores, e estes não os livros didáticos interferindo na performance de nossos estudantes nas avaliações internacionais.

É possível que a análise parcial de apenas um tópico tenha produzido tais resultados, e que tenha faltado uma análise global de todos os temas abordados na obra. Em pesquisas futuras, analisaremos outros fatores que impactam a educação de um país, como a formação de professores, qualidade das escolas e suporte dos órgãos responsáveis. 


\section{REFERÊNCIAS}

ARAÚJO, E. O. Construções com régua e compasso e algumas aplicações. Dissertação (Mestrado em matemática), Universidade Federal do Ceará, Fortaleza, p. 51, 2016

BATISTA, A. A. G. Um objeto variável e instável: textos, impressões e livros didáticos. In: ABREU, M. (Org.). Leitura, história e história da leitura. Campinas, Mercado das Letras, 1999.

BITTENCOURT, C. M. F. Em foco: História, produção e memória do livro. Disponível em: <http://www.scielo.br/pdf/ep/v30n3/a07v30n3.pdf>. Acesso em: 04 de março de 2018.

BRASIL. Lei de diretrizes e bases. Brasília, 1996

Parâmetros curriculares nacionais: terceiro e quarto ciclo do ensino fundamental: introdução aos parâmetros curriculares nacionais. Brasília, 1998

Parâmetros curriculares nacionais: matemática. Brasília, 1998

Guia de Livros Didáticos. Brasília, 2016

CANDEIAS, M. R. Análise de uma coleção de livros didáticos para o ensino médio. Dissertação (mestrado em matemática), PROFMAT, Rio de Janeiro, p. 81,2015

CARVALHO, R. S. Um estudo comparativo sobre educação matemática entre Brasil e Japão. Dissertação (Mestrado em educação), Universidade de São Paulo, São Paulo, p.87, 2015

CERQUEIRA, D. S. Um estudo comparativo entre Brasil e Chile sobre educação Matemática e sua influência nos currículos de Matemática desses países. Tese (Doutorado em educação Matemática), Pontifícia Universidade Católica de São Paulo, São Paulo, p. 254, 2012

CIAVATTA, M. Estudos comparados: Sua epistemologia e sua historicidade. Trab. Educ. Saúde, v.7, Rio de Janeiro, 2009

CHOPPIN, A. História dos livros e das edições didáticas: sobre o Estado da Arte. Educação e Pesquisa, v. 30, № 3, p. 549-566, São Paulo, 2004 
CONCEIÇÃO, S. V. Análise de uma coleção de livros didáticos para o ensino médio. Dissertação (mestrado em matemática), PROFMAT, Rio de Janeiro, p. 88,2015

DANTE, L. R. Livro didático de matemático: uso ou abuso. Em Aberto, ano 16, oㅡ 69, Brasília, 1996

Tudo é matemática. $1^{\text {a }}$ edição. Editora Ática, São Paulo, 2002

DASSEI, B. A. Paratextos editorias e História da Educação Matemática: uma leitura de livros didáticos. Lisboa, 2011

EVES, H. Introdução a história da matemática. Tradução de Hygino $\mathrm{H}$. Domingues. 5 ${ }^{\mathrm{a}}$ edição. Editora Unicamp. Campinas, 2007

FLEURY, M. T. L., MATTOS, M. I. L. Sistemas educacionais comparados. Estudos avançados, 1991;

FONTES, V. História e verdade. Teoria e educação no labirinto do capital. Petrópolis, 2001

FRANCO, C. et al. Qualidade e equidade em educação: reconsiderando o significado de "fatores intraescolares". Ensaio: Avaliação e políticas públicas em educação, v. 15, no 55, p. 277-297, Rio de Janeiro, 2007

FRISON, M. D. et al. Livro didático como instrumento de apoio para a construção de propostas de ensino de ciências naturais. Anais do VII Enpec, Florianópolis, 2009

GENETTE, G. Paratextos editoriais. Ateliê editorial, Cotia, 2009

GÉRARD, F. M.; ROEGIERS, X. Conceber e avaliar manuais escolares. Traduzido por FERREIRA, Julia; PERALTA, Helena. Porto, Ed. Porto, 1998.

GUIMARÃES, R. R. Análise de uma coleção de livros didáticos para o ensino médio. Dissertação (Mestrado em matemática), PROFMAT, Rio de Janeiro, p. 91,2015

JÚNIOR, L. F. A. S. Análise da apresentação de áreas de figuras planas nos livros didáticos do $9^{\circ}$ ano do ensino fundamental. Dissertação (Mestrado em matemática), PROFMAT, Rio de Janeiro, p. 58, 2013

LEIVAS, J. C. P. Educação geométrica: Reflexões sobre o ensino e aprendizagem em geometria. Educação matemática em revista, v. 1, № 18, p. 916, Rio Grande do Sul, 2012 
LIMA, M., ANDRADE, R. S. J., LIMA, M. G. B. Realidade Educacional do Brasil e do Canadá: Pistas a partir dos resultados em leitura do PISA. VI Colóquio Internacional "Educação e Contemporaneidade, São Cristóvão, 2012

MOCROSKY, L. F.; MONDINI, F.; ESTEPHAN, V. M. O ensino de geometria no Brasil: Alguns aspectos da sua origem nos livros didáticos brasileiros. III Simpósio Nacional de Ensino de Ciência e Tecnologia, Ponta Grossa, 2012

OECD, PISA 2015: PISA Results in Focus. Paris, França, 2016

OLIVEIRA SOUZA, A. Um olhar sobre a Prova Brasil: análise dos resultados em matemática. XVIII EBRAPEM, Recife, 2014

ONTÁRIO. The Ontário Curriculum: Grades 1-8. Ontário, 2005 Guidelines for Approval of Textbooks. Ontário, 2008

PEREIRA DOS SANTOS, J. B., TOLENTINO-NETO, L. C. B. O que os dados do SAEB nos dizem sobre o desempenho dos estudantes de Matemática. Edu. Matem. Pesq., v. 17, № 2, p. 309-333, São Paulo, 2015

PUTNOKI, J. C. Elementos de Geometria e desenho geométrico: Volume 1. Editora Scipione, v. 4, 1991

RICHAUDEAU, F. Concepción y producción de manuales escolares: guia práctica. Tradução de DINTRANS, Radamante. Bogotá: Editorial de la Unesco,1981

ROSA, C. P., RIBAS, L. C., BARAZZUTTI, M. Análise de Livros Didáticos. III Escola de Inverno de Educação Matemática, Santa Maria, 2012

ROSEMBAUM, L. S. Estudo comparativo sobre a Educação Matemática presente em currículos: Brasil e Uruguai. Tese (Doutorado em educação Matemática), Pontifícia Universidade Católica de São Paulo, São Paulo, p. 403, 2014

SANTANA FILHO, F. Análise textual: outro olhar sobre a análise de livros didáticos. Dissertação (Mestrado em Educação matemática), Universidade Federal de Mato Grosso do Sul, Campo Grande, p. 86. 2017

SCHNEIDER, S., SCHMITT, C. J. 0 uso do método comparativo nas ciências sociais. Caderno de Sociologia, v. 9, p.48-87, Porto Alegre, 1998

SILVA, A. G. Construções geométricas com régua e compasso. Dissertação (Mestrado em matemática), PROFMAT, Maceió, p. 122, 2013

SILVA, C. I. D. N. Proposta de aprendizagem sobre a importância do desenho geométrico e da geometria descritiva. Dissertação (Mestrado em Educação), Pontifícia Universidade Católica do Paraná, Curitiba, p. 103, 2006 
SILVA, C. M. S. Livro aberto: Uma análise histórica. Revista do programa de pós-graduação em educação matemática da Universidade Federal de Mato Grosso do Sul, Mato Grosso do Sul, v. 8, 2015

SOUZA, R. D. O resgate do ensino das construções geométricas na educação básica. Dissertação (Mestrado em matemática), PROFMAT, Ilhéus, p. 60, 2013

SOUZA, T. P. S. O uso do desenho geométrico como motivador de aprendizagem no ensino de área de figuras planas. Dissertação (Mestrado em matemática), PROFMAT, Cruz das Almas, p. 78, 2015

VALENTE, W. R. Uma história da matemática escolar no Brasil (17301930). $2^{\mathrm{a}}$ edição. Editora Anna Blume, São Paulo, 2007

Por uma história comparativa da educação da matemática. Cadernos de pesquisa, v. 42, ํo 145, p. 162-179, São Paulo, 2012

VORPAGEL, K. S. Livro didático de matemática: Perspectivas de sua criação pelos autores. Dissertação (Mestrado em educação), Universidade Federal do Paraná, Curitiba, p. 244, 2008

ZUIN, E. S. L. Da régua ao compasso: As construções geométricas como um saber escolar no Brasil. Dissertação (Mestrado em educação), Universidade Federal de Minas Gerais, Belo Horizonte, p. 211, 2001 